$S_{419}$
$\mathrm{H}_{2}$ 


$\sqrt[*]{6}$

\section{HALE'S HISTORY OF}

AGRICULTURE

潥 BY DATES. 学

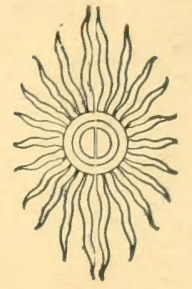

A SIMPLE RECORD OF

HISTORICAL EVENTS and VICTORIES OF PEACEFUL INDUSTRIES.

WHICH IS ISSUED MONTHLY AT ST. LOUIS, MO.

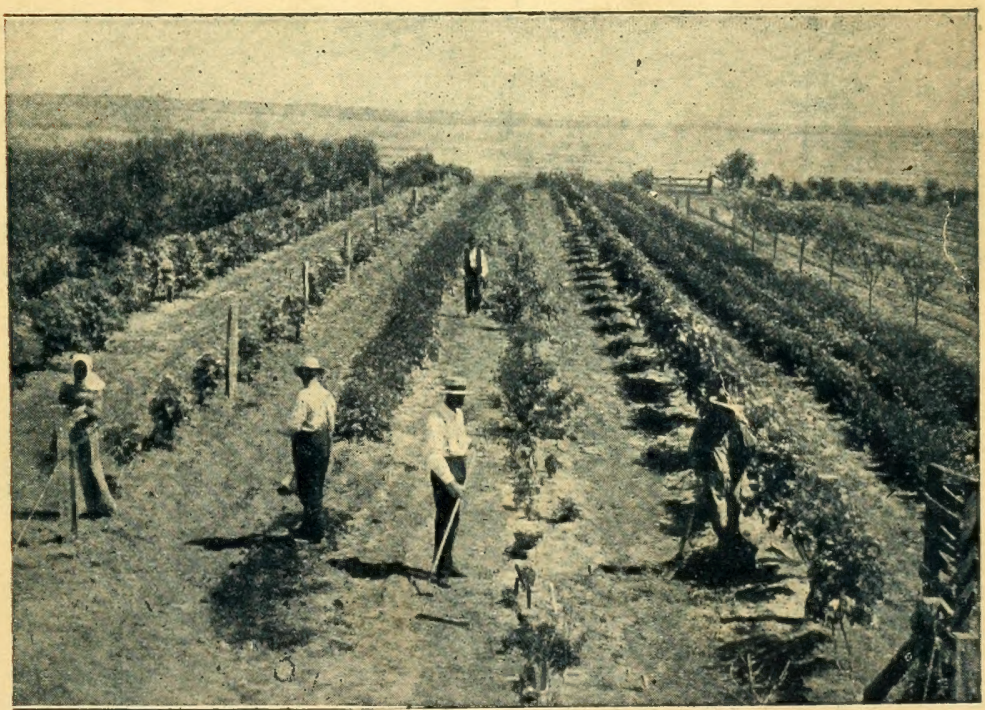

PUBLISHED BY THE HALE PUBLISHING CO, 3550 VISTA AVE., ST. LOUIS, MO.

FIFTH EDITION - JULY, 1915. 


\section{Greatest Value Ever 0ffered For \$1.00}

THE VERY BEST MONTHLY FARM PAPER FOR TWO YE.ARS AND A COPY OF LAIRD \& LEE'S
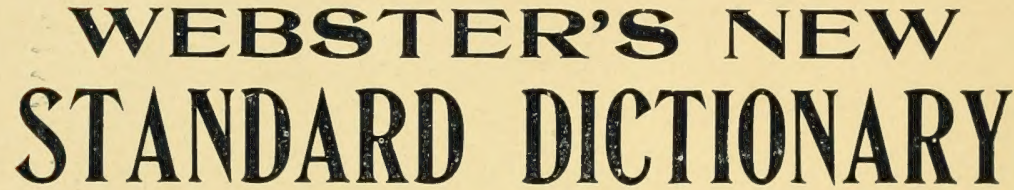

WHICH IS THE MOST COMPACT, USEFUL, HANDY, INSTRUCTIVE BOOK EVER ISSUED BY THE AMERICAN PRESS.

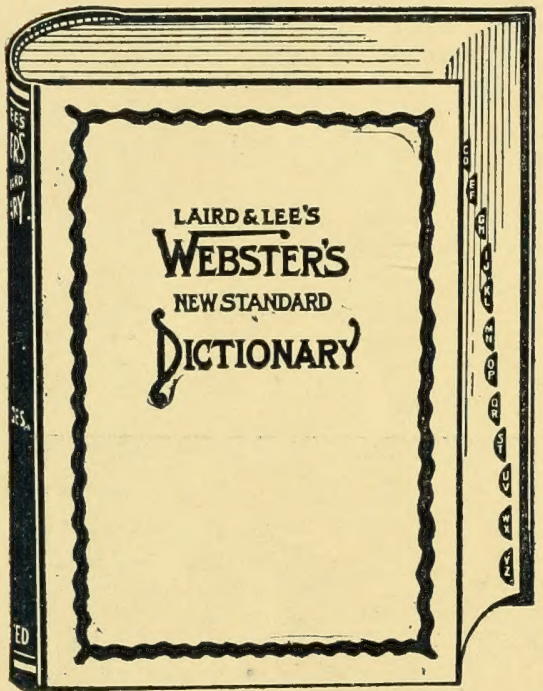

T AIRD \& LEE'S Webster's 1 New Standard Dictionary of the English Language - a wonderful book, 756 pages in all, 840 illustrations, substantially bound, gilt title, red edges, patent thumb index. Special edition for office and general use on farm s, estates, ranches, etc.; massive but handy; contains ten encyclopedic features, supplement of new words, dictionaries of biography, geography, musical terms, Biblical, c l a s s i c l, historical and mythological names, foreign phrases, English word-building, rules in orthography, current abbreviations, metric system with c o n v e r s i o n tables; weighs twenty-eight o u n ces. We are us ing WEBSTER'S NEW STANDARD DICTIONARY as a subscription premium to the best monthly farm paper in the United States.

\section{The National Farmer and Stock Grower}

is a nice, clean, general farm publication, full of practical, interesting and instructive information. it contains good reading for all the family. It is very useful to general farmers, to dairymen,

: to vegetable and fruit growers, and especially so to cattle, hog and $\because$ : sheep raisers and feeders, to horse and mule raisers and dealers, and it contains more good poultry facts than most of the poultry papers. The best live stock illustrations appear in THE NATIONAI FARMER AND STOCK GROWER. There are thirty-two pages, four columns to the page. It is published monthly.

\section{SPECIAL INDUCEMENTS.}

Our offer to you: Send us One Dollar and we will send you THE NATIONAL FARMER AND STOCK GROWER for two years, and we will also send you, postage paid, safe delivery guaranteed, one copy of this great WEBSTER'S DICTIONARY. We also agree to refund money and pay return postage to anyone who is not satisfied with the bargain. Address,

The hale PUblishing CO., 3550 Vista Ave., St. Louis, Mo. 


$$
a^{x^{a}} x^{2}
$$




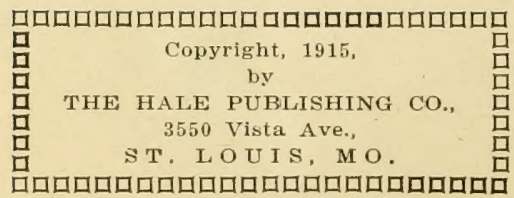

品




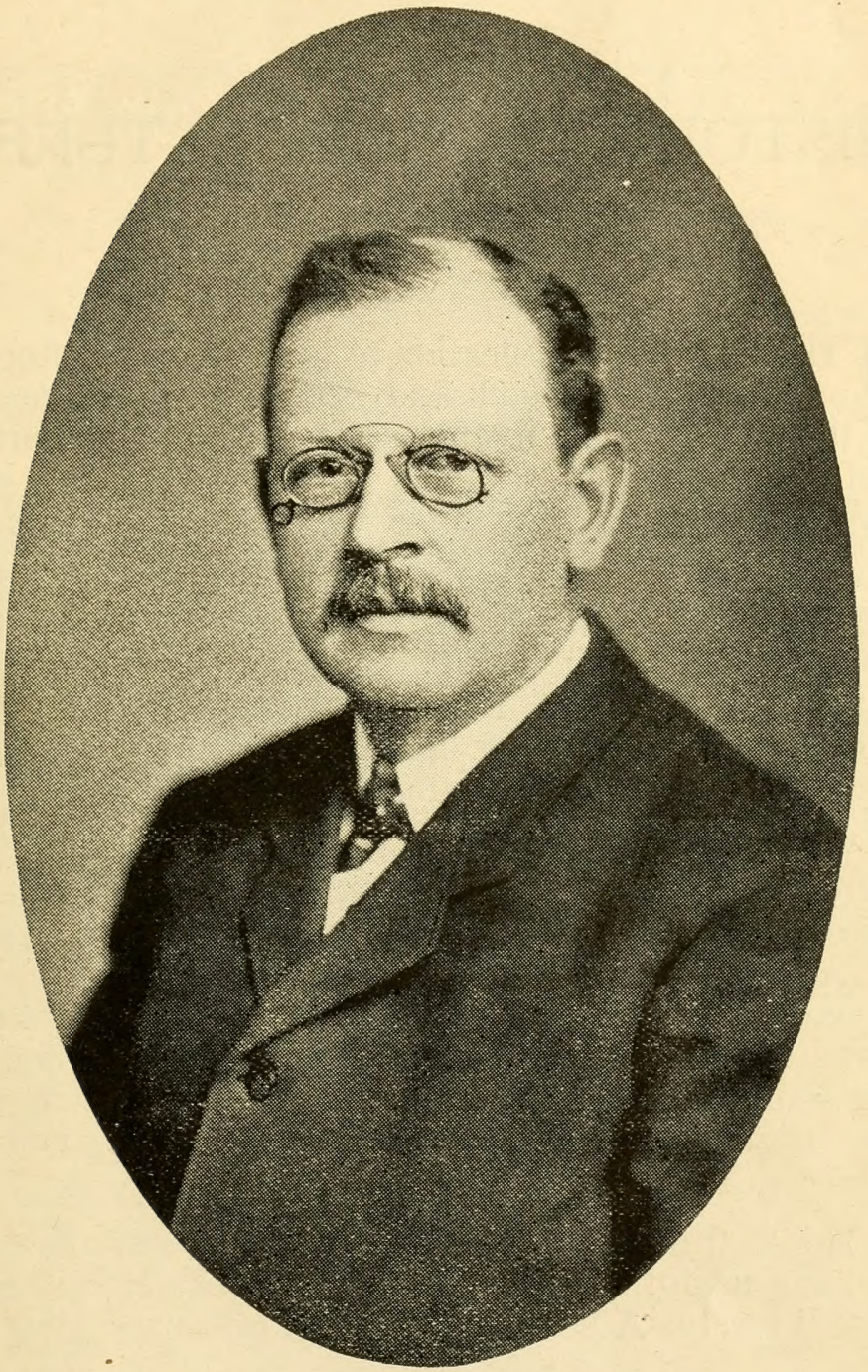

Mr. PHILIP H. HALE,

Editor and Compiler

History of Agriculture by Dates. 


\section{PREFACE. \\ ...HALE'S... \\ HISTORY OF AGRICULTURE \\ BY DATES.}

THIS is the multiplication of brief items relating to the Live Stock and Agricultural History of the World. The intention was to make a short but interesting list of items without publishing a volume of any size.

In the attempt to grow a little unimportant shrubbery we accidentally planted a Tree of Knowledge, which, having lived and borne fruit for four successive editions, is destined to become the great and lasting historical record of the Peaceful Industries of Humanity.

We have no apology to offer for the scraps of information which are presented in the book. Two-thirds of the items appearing in The History of Agriculture by Dates occurred during the lifetime of the editor and were recorded in the current news and literature of the day. The earlier items are found in so many different compilations that the original source of many facts of history contained in this book is unknown.

This is the edition of 1915 . It is not complete, but is a useful and interesting book of reference. Use it freely. A better edition will be issued later.

Respectfully submitted by

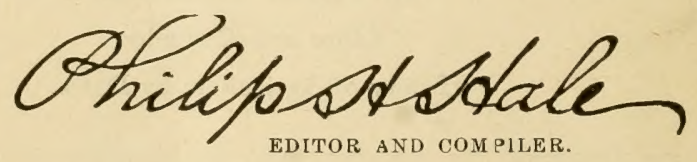




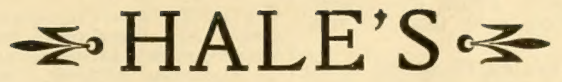

\section{HISTORY OF AGRICULTURE}

B Y DATES.

Edited by Philip H. Hale-Copyright by the Hale Publishing Co.

"If History without Chronology is dark and confused, Chronology without History is dry and insipid." - A. HoLmes.

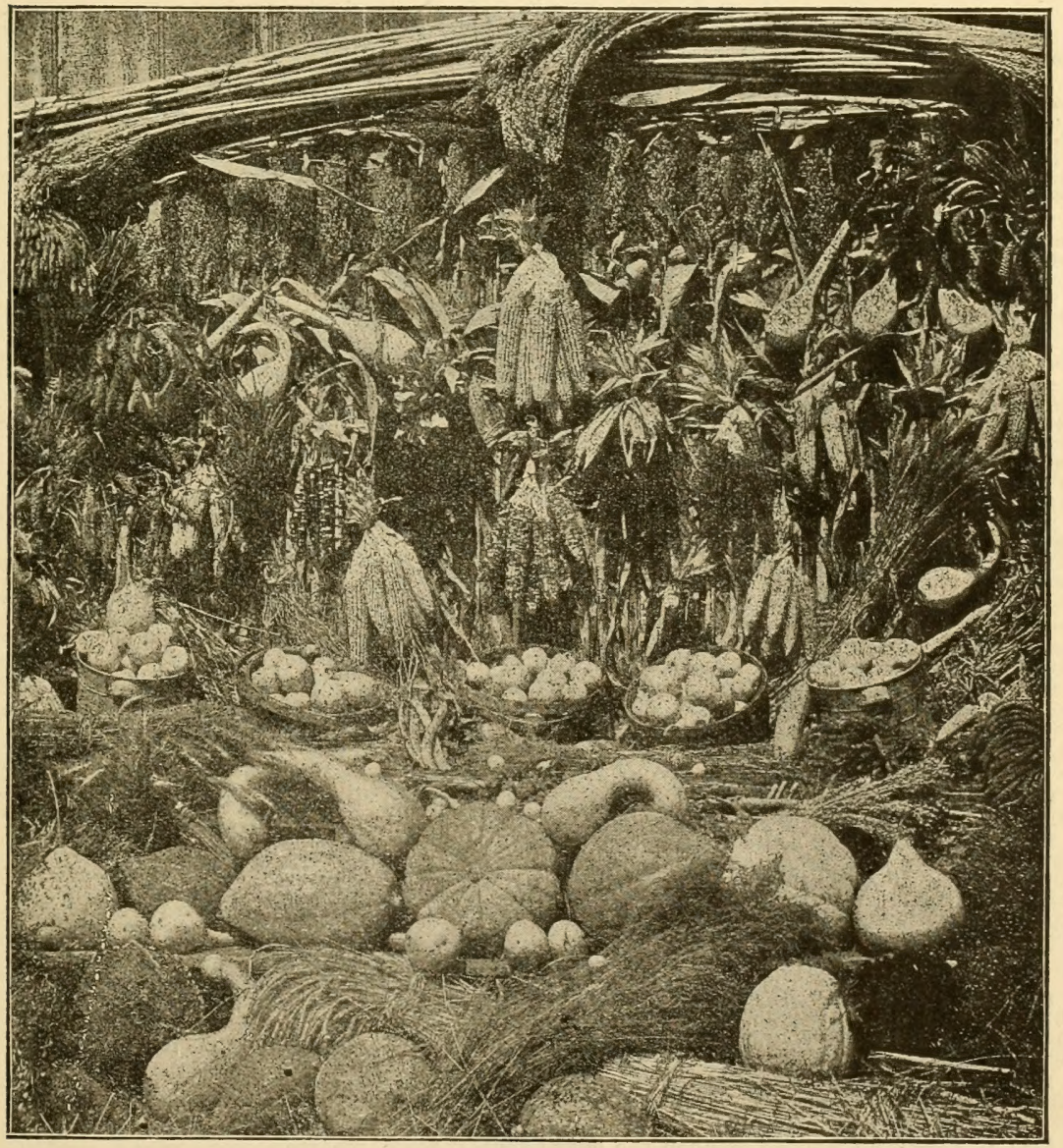

"THE EARTH AND THE FULLNESS THEREOF."

A variety of products from an ordinary farm in the center of the United States. 
SCRIPTURAI QUOTATIONS.

And God said: "Let there be light;" and there was light. The ereation of the world.

"And God made the beast of the earth after His kind and cattle after kind, and everything that creepeth upon the earth after, His kind, and God saw that it was good."

And God said: "Let the earth bring forth grass, the herb yielding seed and the fruit tree yielding fruit after $H$ is kind, whose seed is in itself, upon the earth;" and it was so.

"God made the earth and the heavens. And every plant of the field before it was in the earth, and every herb of the field before it grew, for the Lord had not caused it to rain upon the earth and there was not a man to till the ground.'

Year.

4241 B. C.-Egyptian astronomers of the Nile Delta gave to mankind the calendar which divides the year into 365 days. Also first recorded date in the history of the world.

4004 B. C.- "Therefore the Lord God sent him (Adam) forth from the garden of Eden to till the ground,from whence he was taken."

4004 B. C.- "Thorns also and thistles shall it bring forth to thee, and thou shalt eat the herbs of the field."

4003 B. C.- "Abel was a keeper of sheep and Cain was a tiller of the ground.

3875 B. C.- "And Adah bare Jabal; he was the father of such as dwell in tents and have cattle."

3500 B. C-According to archaeologists, horses were domesticated in Babylonia and the country now known as Asia Minor at a very early period. Actual date is uncertain within a few hundred years, and the information is obtained from the characters appearing on the ruins of ancient buildings.

2700 B. C.-At this early day certain cereal and forage grasses now classed as millets formed one of the chief sources of food in China. The Chinese also claim that wheat was used as food by them at the same period as a direct gift from Heaven

2349 B. C.- "And the rain was upon the earth forty days and forty nights."

2349 B. C.-According to the scriptures, Noah entered the ark, taking with him of clean beasts, by sevens, the male and the female, and of beasts that are unclean, by Iwos, the male and his female, and the fowls of the air, by sevens, the male and the female.

2348 B. C.- "Neither shall all flesh be cut off any more by the waters of a flood: neither shall there any more be a flood to destroy the earth."

2348 B. C. "While the earth remaineth. seed time and harvest, and cold and heat, summer and winter, day and night, shall not cease."

2000 B. C.-The Date Palm had already become a well-known fruit tree at this time.

2000 to 1400 B. C.-Hindoos interested in cattle raising valued their cows according to the yield of butter.

1918 B. C.- "And Abraham was very rieh in cattle, in silver and in gold."

1918 B. C.-The land could not support the immense flocks and herds of Abraham and Lot, therefore they separated. Then Abraham said unto Lot: "Let there be no strife between thy herdsmen and my herdsmen. If thou wilt take the left hand, then I will go to the right. If thou will go to the right I will go to the left."

1898 B. C.-Abimilech gave many valuable presents to Abraham, such as oxen, she-asses and he-asses, but no mention is made of horses or swine.

1804 B. C.- "Then Isaac sowed in that land and received in the same year an hundred fold,"

1747 B. C.- "And Reuben went in the days of wheat harvest and found mandrakes in the field and brought them unto his mother Leah."

1746 B. C.-Jacob was the first to recognize live stock breeding as a possibility.
He bred streaked, speckled and spotted cattle and mated the strong with the trong for his own purposes. He also made he first known contract for running stock on shares, which resulted in his getting the best and largest share.

1715 B. C-Commencement of the seven years of abundance in Egypt, followed by seven-years' famine, as foretold by Joseph to Pharaoh. "And Joseph gathered corn as the sand of the sea, very much, until he eft numbering; for it was without mber.

1700 B. C.-Joseph gave the Egyptians bread in exchange for horses. First menion of the horse in the scriptures.

1500 B. C.-A tomb in Egypt probably built about this time bears a painting which shows the various operations conneeted with harvesting the grain.

1491 B. C.- "And the flax and the barley was smitten, for the barley was in the ear and the flax was bolled. But the wheat and rie were not smitten, for they were not own up.

1490 B. C.- "And every oblation of thy meat offering shalt thou season with salt * With all thine offerings thou shalt

1471 B. C.- "Speak unto the children of Israel that they bring thee a red heifer without spot, wherein is no blemish and which never came yoke"

1451 B. C.- "A land of wheat, and barley, and vines, and fig trees, and pomegranates: a land of oil olive and honey.

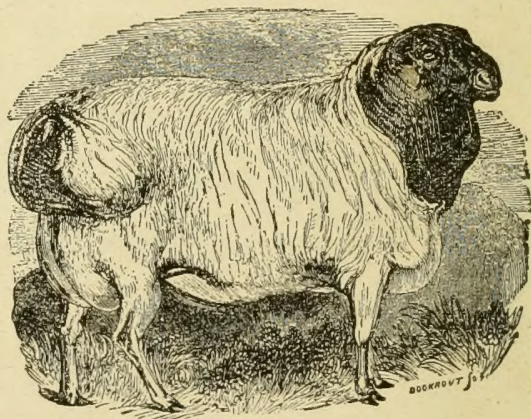

FAT-RUMPFD SHEEP. - According to the earliest authentic accounts, the flocks of the patriarchal shepherds were of the fatrumped breed. This is particularly an Asiatic sheep and found in Palestine in larger numbers than any other breed. It is also found in purest strain in the great Tartary of Russia. It is known as the largest breed of the unimproved sheep. The illustration is from a book entitled "The American Shepherd," edited in 1843 by L. A. Morrell. Several other illustrations are from the same volume.

1450 B. C.-Thothmes, III., greatest of the Egyptian kings, left a papyrus record of his contest of Mesopotamia, in Asia, and priding himself upon obtaining the racing horse and introducing him into Egypt.

1400 B. C.-Fowls, the oldest recorded of our domestic animals, were introduced into China about this time. An ancient Chinese authority says: "Fowls are creatures of the West." The common fowl is supposed to have sprung from the wild jungle cock in the East Indies.

1312 B. C.- "And Boaz said unto Ruth "At mealtime come thou hither and eat of the bread and dip thy morsel in the vinegar; and she sat beside the reapers and he reached her parched corn."

1193 B. C.- "To Helen in the Palace, weaving there an ample web, a shining double robe, whereon were many conflicts fairly wrought."-Quotation from the Siege of Troy.

1184 B. C.- "Endured by the horse-taming sons of Troy." -Quotation from the Trojan
War. 
1030 13. C.-Then all the king's sons arose and every man gat him upon his mule and Hed.

1030 13. C.- "And it came to pass that after two full years Absalom had sheep shearerw in Baalhazor.

1020 33. C.-King David of Israel was a Freat ranchman, as evidenced by his own words:- "For every beast of the forest is mine and cattle upon a thousand hills."

1015 13. C.--King David said: "Take with you the servants of your Lord and cause Solomon, my sor, to ride upon mine own mule."

1014 13. C.- "And Solomon had forty thousand stalls of horses for his chariots and lwelve thousand horsemer; barley, also, and straw for their horses, and dromedaries lirousht they also into the place where the iflicers were."

1014 B. C.-...And Solomon's provisions for one day was thirty measures of tine flour and three score measures of fine meal, ten fat oxen and twenty oxen out of the pastures and an hundred sheep, besides hart., King Solomon's life recorls the first stallfed cattle and fatted poultry.

1000 13. C.- "Better a dinner of harhs Where love is than a stalled ox and hatret therewith." From the Proverbs of Solomon.

992 B. C.- "And Solomon had horses brought up out of Egypt and the king's merchants received linen yarn at a price,"

906 B. C.-And Ahale said unto Obadiah: "Go into the land until all the fountains of water and unto all brooks; peradventure we may find grass to save the horses and mules alive that we lose not all the beasts."

900 B. C.-The poet Homer Hourished about this time. In his Odyssey he says

"He neyt betakes him to his evening cares, And, sitting down. to milk his ewes prepare of half their udiers eases first the dams.

Then to their mothers' teats submits the lambs.

Half the white stream to hardening cheese he pressed,

And high in wicker baskets heaped; the rest

Reserved in lowls, supplied the mighty feast."

896 B. C.- "And Mesha, King of Moab, was a sheepmaster and rendered unto the King of Israe! one hundred thousand lambs and an hundrea thousand rams with the wo0l."

$753 \mathrm{~B}$. C.-This is the year in which rome was founded by romulus.

795 B. C. - "Doth the plowman plow all day to sow? Doth he open and break the clods of his ground? When he hath made plain the face thereof, doth he not cast abroad the fitches and scatter the cummin and cast in the principal wheat and the appointed baxley and the rie in their places?'

725 B. C.- "For his God doth instruct him to discretion and doth teach him: "For the fitches are not threshed with a threshing instrument, neither is a cartwheel turned about the cummin, but the fitches are beaten out with a staff and the cummin with a rod."

708 B. C.- The Grecian colony of Tarenline, in Italy, estahlished a breed of finewool shcep,imported there from Asia Minor.

680 B. C.-The horse was introduced into the arena ly the Greeks in the twenty-third Olympiad and the birth of horse racing may be fixed at this time. In the beginning the horses were ridden and the contests were over a distance of four miles: later, in the twenty-fifth Olympiad, chariots were iniroduced.

600 B. C.-At this time Angora goats were known to exist at Angora, Asia Mino.

595 B. C.-"Take thou also unto thee millet and fitches, and put them in one vessel and make thee bread thereof."

550 13. C.-Cincinnatus Roman patrician, called from his farm to the dictatorship of Rome in order to save the state. He sucreeded in hringing peace to his country, and then returned to his farm.
510 B. C.-Darius, one of the Persian Chiefs, who had succesded in dethroning the usurper, the false Smerdis, was elected King of Persia. The Chiefs agreed to meet arly one morning on horseback and to bestcw the crown unon the one whose horse reished first after sunrise. It appears that the groom of Darius, apprised of thls project. led his master's horse in the night with a mare to the appointed place, and in onsequence of this stratagem the horse of Darius neighed loud and long when the Chiefs were assembled. Darius was then saluted as ring, and the cholce was approver by the people.

500 13. C.- "For he hath given you rain moderately, * * * And the floors shall re full of wheat and the fats shall overflow

495 13. C. Job was a large stock owner. His substance was 7,000 sheep, 3,000

180 13. C.-The battle of Thermonylae between the Greeks and the Persians was fought in this year.

160 13. C.- Hippocrates knew something of the movement of the blood.

150 13. C.-Butter used by the Scythlans, the people inhabiting the country near the Black and Caspian seas,

1015. C.-About-this year Xenophon, a Greek historian and soldier, wrote a deseription of a good horse and giring in structions how one may be the laast deceived in the purchase of horses.

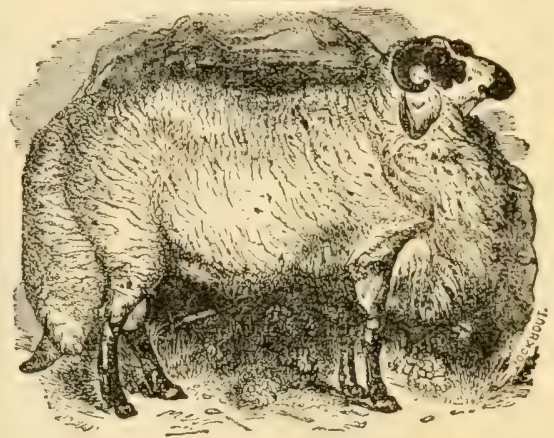

THE FAT-IIILFD SHEEP is considered as a Persian production. This is a pure breed found throughout Asia and a part of ifrica. They are herded upon the open country, The carpets and rugs for which Persia is famous are manufactured from the wool of these sheep.

384 I. C.-Aristotle taught that in man and the higher animals the blood was laborated from the food in the liver, thence carried to the heart and by this argan through the veins over the body. It the bloon.

340 13. C.-Theophrastus, Greek philosopher, one of the first to situdy plant growing. He preserved the writings of Aristotle. He spoke of the productions of old pear trees.

31\% B. C.-The Appian Way the "Queen of Hoads," extending 350 miles from Rome to Drumdisium, was begun this year by Caesar Appius Claudius. It has borne the traffic of 2,000 years without material injury.

264 B. C.-Carthage, in Northern Africa. at war with Rome, almost continually, until destroyed in the year $146 \mathrm{~B}$. C.

149 B. C.-Cato, the Censor, Roman citizen. died in this year. He gave to the world the most minute particulars regarding the management of slaves on his large Sabine farm, also all the detalls of hur bandry. from the plowing to the reaping and thrashing of the crop.

140 B. C. As the Romans conquered the smaller states of Italy they took possession of the conquered lands, passed the Agrarian Iaw, which enacted that no citizen should 
possess more than 500 acres The enforcement of this law occasioned civil war, which lasted several years.

80 B3. C.-Fine-wool sheep of Spain spoken f by the historian Strabo.

79 B. C. - This is the year of the eruption of Mount Vesuvius, wheu Pompeii and ITerculaneum were destroyed.

Colosseum of Co The construction of the Colosseum of Rome was begun this year under the direction of the Emperor Vesgon.

70 B. C.-According to the naturalist, Piny, the common cherry tree was introduced into Italy by the Roman soldier Lucullus from Cerasus, in Pontus, Asia inor, about this time.

60 13. C.-Butter first used by the Portu55 B. C.-This is the year in which Julius Caesar first visited Britain.

14 .B. C., March 15.-This was the day of the assassination of Julius Caesar in 10 B. C.-Virgil mentions pears which he received from cato.

10 13. C. - In the Georgies, a poem writtan about this time and which is the best known of the ancient works on agriculture, brino down the advises husbandmen to sown cern, and when the field is parched and the plants drying, convey it from the brow of a hil! in channels." This is the tirst writing on irrigation.

37 B. C.-In this year the Romans under the Hmperor Agrippa built the famous Tantheon of concrete. This building is still standing, and the splendid dome, 142 feet in span, is one of the sights of the Im-

CHRISTIAN ERA-FIRST CENTURY.

31.- "The kingdom of heaven is like to a and sow mustard seed which a man took least sowed in his field, which is indeed the least of all seeds, but when it is grown it is the greatest among herbs and becometh a tree, so that the birds of the air come and
lodge in the branches thereof."

32.-And Jesus said unto him: "No man having put his hand to the plow, and looking back, is fit for the kingdom of God?

40.- An interesting and valuable item appeared in the "Acta Diurna," a record kept in Rome during the reign of the Emperor Caligula and reproduced later by Petronis Arbiter in his work entitled "The Supper of Trimalchio," It seems that Trimalchio was a farmer near Cumae, in Italy, and his farm occupied an immense extent of territory. The work referred to says: "On June 25th, on Trimalchio's farm near Cumac, were born seventy children whom thirty-six were of the male sex. The same day fifty thousand modii of wheat were removed from the thrashing floor to the granaries: tive hundred young oxen were broken. The same day one of the slaves, named Mithridates, was executed by crucifixion, because he had cursed the sacred name of the emperor.

50.- "But others fell into good ground and brought forth fruit, some an hundred-fold some sixty-fold and some thirty-fold."

50.- About this time Lucius Junius Moderatus Columella. a Roman citizen, wrote 1 welve books on agriculture, one of which on gardening, entitled De Re Rustica, is in ierse. His works are still extant, translations being available.

50.- A supposed improved variety of cherry was introduced in Britain about the middie of the first century.

51.--In the reign of Emperor Claudius, Columella, a distinguished agriculturist, introduced many of the Tarentine breed of sheel from Italy into Spain, which country was under Roman dominion at that time. He also was a general improver of sheep and became the principal originator of an immense fime-wool sheep husbandry, which through Spain has enriched three continents-Europe, America and Australia.

64.-Poppaea Sabina, wife of Nero, Emperor of the Romans, is reported to have paid a sum equal to American four cents a quart for asses' milk to bathe in.

75.-In Pumpeii, an ancient city of Naples, afterwards destroyed by an eruption of Mount Vesurins, it is stated that a sixounce loaf of wheat bread cost a sum equal o three cents of the present day.

75.-Publicus Cornelius Tacitus, Roman historian, mentions the manufacture of woolen cloth at Cirencester, Gloucestershire, in England, stating that the fullers (engaged in finishing cloth) were allowed to dry their cloth by the roadsides.

7\%.-Pliny, the Elier, Roman author, born A. D. 23, left a work entitled "Natural History." in his writings there is the first account of a machine for reaping grain. He says: "In the extensive fields in the lowlands of Gaul, vans of large size, with projecting teeth on the edge, are driven on two wheels through the standing grain by an ox in a reversed position: in this manner the ears are torn oft and thrown into the van.

\section{TIE THII) CENTURY.}

280.- - It is generally helieved that about his time timperor Probus encouraged the planting of vineyards in Britain.

\section{THE HOURTI CENTURY.}

3.5.-Inc!uded in the writings. which sert that Egypt, Nubia, Assyria and Perita all had horses before Arabia, is the assertion that the Roman Emperor Constantine presented the Arah Sheiks of the trih called Yemen with 200 well-bred horses rom Cappadocia, in Asia Minor. Constanied in the year 3.37 .

100.-From this year to 409 the Homans were leaving lsritain.

THE FIFII CENTUEY.

45\%.-Year in which the city of Venice vas foumlerl.

476 - About this year commenced a were called the Dark $A$ ges.

TIE SEVWNAI CENTURY.

6:2, June 20.-This is the rear of the Ilegira, the name given to the ilight of the Prophet Mahomet from Mecea.

TIE FIGHTI CENTURY.

732. - The battle of Tours, in which Charles Martel defeated the Saracens, is considered as contributing to the establishment $0:$ horse breeding in LaPerche and Normandy. On distribution of the spoils of var many Saracen horses went to these provinces, where they were crossed upon the mares of Brittany, and on the luxuriant pasturage developed a draft horse of great exceilence, the Percheron horse of France.

TIE NINTII CENTURY.

89.5. - King Alfred the Great of Englane encamped his army near London to protect the harvest reapers while gathering their crops against excursions of the Danes.

\section{THE TENTII CENTURY.}

936.-About this time, according to Whyte, in his History of the British Turf, the earliest mention of race horses 21 England, ealled running horses in those lays, was when Hugh Capet, founder of the royal house of that name in France, sent horses as a present to King Athelstane, whose sister, Ethelswitha, he was soliciting in marriage,

\section{TIE FLEVENTI CENTURY.}

1016.-Foiton jacks of France mentioned n literature of that day.

1010 (about).-First windmills erected in Europe.

1066. -Iforse shoeing was introduced into England from Normandy by William the Conqueror.

1100. - The Japanese court ladies as early this date prepared a favorite perfume from the liamanas rone. 
TIIE TWETFTI CEN'TUIR'.

1150 (about). Cotsivold sheep importea? into ingland from spain. This is not quife authentic. A century later Cotswolds were a well-known breed in angland.

159.-Smitlifield, in the center of Londor lirst mentioned as a live cattle marlet.

115\%.-William Hale-Hale, historian an editor of the "Domestay Book" of st. 'aul's Cathedral of London, England, mal: 3 record of lpasing the ehureh farms in Hert isnant shou!d cultivate and conduct the in rm on what wa's called the three-field husl.aniry; a rotation of about one-third in vats, one-third in wheat or rye, and onethird fallow or "terre warecunda."

custon: was to rotate crops from beginning in end of the lease and to restore the land 10 the owner in the condition it was leased.

1158. - In the accounts of the British gov ernment of $1158-9$ occur mention of pas ments to the vine dressers of Windsor. It were enclosed by a ditch.

1165. The earliest trawing or view of a monastic garden in Fugland was that of Canterbury, and was drawn lyy the Engineer Wibert. It is now preserved in the librar. of Trinily College, Cambrige. The plun tecords the trees and rines, fish ponds, eto

1176.- Early evidence of the existence of orchardis is a Bull of Pope Alexander, III issued in this year, confiscating the property wi the monks of Winchenley, in Gloucester shire. England, with the "town of Swiring and all its orchards.

1185. - The manufacture of wool first mentioned in English literature

1199.-Iing John of England encouraged horse breedine by importing Flemish stal lions-origin of the Fnglish draft horse.

\section{THE THIRTEENTII CHNTURY.}

1210.-Aceorling to the Historian Speeil Jing Ioin of England received from Mau i) Breos forty cows and a bull, all white with red mars. as a present to his queen, m urrer to appease his majesty, whom hry ii usband. De Breos, had offended.

1:13.- - Alexander Neecham, Bishop of Cirencester, in England, a learned writer. and hirls growing and flowers. He menlioned that a garden should be adorned with ioned that a garden should be adorned with irake. The garden should have parsley an cost, and fennel, lettuce, cress, onions, leek, farlic, pumpkins, shalots and cucumbers. He also mentions meddlars, quinces, Warder pears, peaches and pears at St. Regula,

1215, June 15.-At Rumnmede, King John was forced to grant the English people a great measure of liberty by signing the Iagna Charta.

1\%:6.-At this time a hen in Paris was Eenerally sold for an amount equal to American two cents.

1*19.-A Scottish history mentions black (Galloway) cattle as being reared in great numlers.

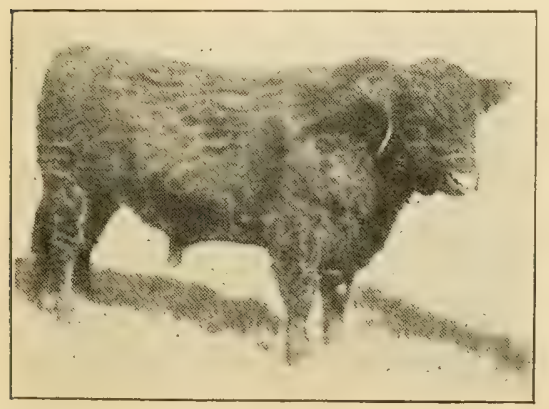

STANILY OF MAPLES-A YEARLING GALLOWAY BULL. Junior and grand champion of the Galloways at the Illinois
State Fair of 1909. Exhibited by C. S Hechtner, of Chariton, Iowa. At the American Royal Show this young bull was first in his class.

1359.-Henry, III., of England, made exensive alteralions at the palace of Westminster. and among payments to carpenters nd other workmen Was an Item of pay ment to lahorers for "levelimg the area of the carden with a roller,"

lit.-Tn this year, in Tenice, it is re ried that a pir sold for the equivalent fifty cents in American money.

1:20. - The first importation of oranges ito Fngland in a cargo of assorted fruit $m$ Spain.

1:9:- The only kind of apple specially ticed in Fngland at this time was the ostard." 'This variety has been preserved n history by the word "Costermonger," the hame by which the sellers of this fruit vere known. The Costard apple was the most popular for several centuries. The Aso eariy fruits.

\section{TIF IOUITENNTH CFNTURY.}

1305.- In the time of Fiward, I., King of England, the "acre" as a land measure was to a standard.

1317.-Accorting to the New Interna. ional Encyclopedia, in August of this year, in Ensland, wheat was twelve times as high n price as in the following September. It was a period of alternations of indolence ind bustle, of feasting and semi-starvation. liye was the hreadstuff of the peasantry. Little manure was used. Oxen, not horses, rere used for teams.

$13: 3 \%$ - Wd ward, IIT, in order to improve

e breed af horses, prohibited exportation. 1310. -First "worsted" manufactured "ut Torsted, in Norfolk, England. TVorsted 38 spun wool manufactured into cloth.

1345. - It this time, in England, and near ondon particularly, fruits and vegetables, uch as then were raised, were sold at a market place near st. Paul's church yard, ut oाing to the "scurrility, clamor and musance $: t^{2}$ the gardeners and their serrants. Which had become so obnoxious to "he peonle dwelling there," the Mayor and lifernien heing appealed to, designated anither place (now called Austin Friars), where sales could be made, and nowhere else.

1346.-- wirst authorization in England for the erection of toll-rates under $\mathrm{King}$ Edward. III.

1352.- The 1 imoner at Winchester CatheIral, in Fneland, mate note that this was a had var for apples; also that the cidur ply gare out.

1369. - A bout the earliest account books of farming operations were kept and preserved at the Norwich Priory and Abingdon Abbey, in England. These accounts show the receipts and expenses of the garden operalions, but not the plants that were grown ir the processes of cultivation.

1380 (atout).-Richard, II., King of England, compelled horse dealers to limit their prices to a fixed maximum.

\section{TIL FIFTENTH CENTURY}

140.2-Sir WVilliam CJopton, an Englishnau, sranted to Thomas Smyth a piece of sround, cailed Dokmedwe, in Houstede, for the ammual payment of a rose to Sir Wiliam and his heirs, the demand for roses being so great in those days that bushels were frequently paid by vassals to their lords. both in England and France.

1430.- In this year it is said that England inported raw cotton from the Levant. which includes Eigypt, Asia Minor, islands and countries east of Italy, in or borderin in the Mediterranean Sea. It was then named cotton rvool.

1410. - The earliest known original work on wardening, written in English, was by In Gardener, and the manuscript exists in Trinity College, Fngland, to this day. It "as called "The Feate of Gardening:" The treatise Wa's so thoroughly practical that the directions it contains might be followed with successul results to the present day. 
1449. - In Fingland the tenant was for the first time secured in possession, during term of lease. against a buyer of the land.

1467.--Permission granted by King Henry, 1V. of England, to export a few Cotswold sheep to Spain.

1469.- In England, the tenant fammer was first protected from having his property carried off for the landlord's debts beyond the amount of rent due.

1472. - In this year, in Venice, Jensen, a publisher, printed the existing works of Colmmella on agricultural subjects which were written in the first century.

1485.-Previous to the reign of Henry, VII., King of England, which began in this year, there did not grow in that country any vegelable or eatable root, such as carrot, parsnip, cabbage, etc.

1488.--In Fngland a law was passed to stop laying arable land to pasture and suffering farm houses to fall to ruin. Owners were required to till a portion of the soil and keep the farm houses in repair.

1490.-Comparative Peace, which followed the Wars of the Roses in England, encouraged a new style of architecture. The gardens were no longer confined within the castle walls. The red brick houses succeeded old castles. Some houses with gardens were soon extended outside the moat. Trellis railings also came into tashion and remained in vogue for many years.

\section{2.-Discovery of America.}

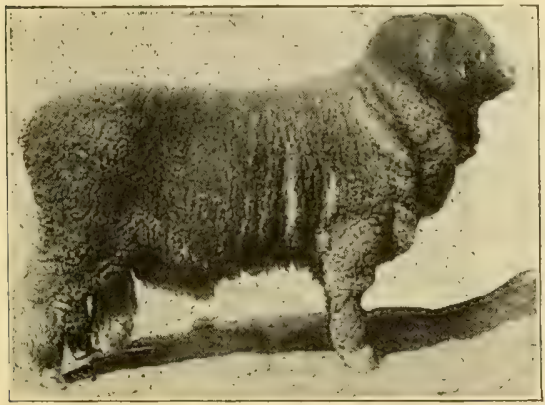

MERINO RAM - TWO YEARS OLD Grand champion, Louisiana Purchase Exposition, St. Louis, 1904. Exhibited by R. D Williamson, of Xenia, Ohio.

1493. Sheen of Spanish origin brought to the United States by Christopher Columbus.

1493. - First cattle intoduced into America hy Columbus fron the West India Islands.

1493.-Hogs brought over by Christopher Columbus on his second voyage, landing

at Hispanola.

1493.-Indian corn (maize) first taken to Europe.

1494.-In this year Henry the Seventh, King of England, passed a law that no one should export a horse or mare, or carry it heyond sea except for his own use. With this exception, that any mare of three year old and upwards, whose price was not above six shillings and eight pence, might be exported; the owner, however, was conspelled to sell her at the port to any

$\mathbf{1 5 0 0 . - I n ~ t h e ~ r e i g n ~ o f ~ H e n r y , ~ V I I . , ~ g e l d i n g ~}$ 1500.- In the reign of Henry, VII., gelding
castratins horses first practiced in England.

\section{THF SIXTEENTI CENTURY.}

1509.-The common garden or bush bean first cultivated in England.

1516. - In this vear the gooseberry bush vas planted in the gardens of Henry VIII King of Fingland.

1520.-At this period hops were first cul ivated in Fingland,

1521. - Cortez, Spanish commander, enter- ing Anahuac, the Aztec capital of Mexico, discovered bufralo in the menagerie of the jing. Montezuma.

1522.- Rice culture reported to be successful in I,ombardy, Northern Italy.

1593.-In a letter written to friends in Europe, Alejandro Geraldine, then Bishop of Santo Domingo, mentions turkeys. He is regarded as the first author who refers to this fowl.

1524.-According to C. L. Bonaparte, in his Natural History of Birds, turkey arrived in England in this year from Spain. Although turkeys were originally from the American islands and continent, the English supposed or were told the birds were originally from Turkey, which gave them a satisfactory name, although they were not enistled to it. At this time all commerce between America and Europe was with spain.

1524. - The apricot introduced into England by Woolf, the gardener to King Henry, VIIJ.

1525. - Spaniards exported the first cattle from the West Indies into Old Mexico.

1526. The pineapple mentioned by Oviedo, who called it Pinas. Oviedo y Valdes was Spanish historian of the new world and was Governor of the Island of Hispanola.

15*\%.-Florida the first part of the main and of the United States to receive lorses from the Spaniards.

1529.-When the king, Henry, VIII, of Fngland, took possession of Cardinal Wolsey's lands, including Hampton Court, he retained John Chapman, the liead gardener. of course, the gaydener received board and odging.

1530.--Salads, carrots and other edible roots first produced in England.

1530.-The strawberry introduced into the rardens of Fingland from Flanders.

1533.-Pichard Harris, an English fruit prower, in service of King Henry, VIII. planted many apple orchards in the county of Kent, near London.

1534. - In England, owing to large numbers of sheep having come into few persons hands, a penalty was imposed on all who kept above 2,000 sheep.

1534-The Book of Husbandry printed in this year. First and best of early Englisl works on agriculture; ascribed to Fitzherbert, a Judge in the reign of Henry, VIII

1534-Fxtract from Book of Husbandry: And bycause that shepe in myne opynyon is the mooste profytablest cattell that any man can hane, therefore I pourpose to speake fyrst of shene."

1534.-Quotation from the Book of Hushandry, published in this year: "A housebande cannot thryve by his corne without cattell, for iny his cattell without corne."

1534.-From the Book of Husbandry: "And in the veginning of March or a lyttel afore, is tyme for a wife to make her garden, and to gette as many good sedes and herbes as be good for the potte and to eate, and as ofte as nede shall require: it must be weded, for els wedes wyl ouercrowe the herbes."

1534. - In Great Britain, different individuals in the previousi years had accumulated in their own hands a number of landed properties, a multitude of cattle, and especially of sheep. Some of them possessed 24,000 sheep, others 10,000 , etc. Tillage was thereby displaced, the country depopulated and the price of sheep and wool raised in an unheardof manner. It was then provided by law that no one, therefore, shall possess more than 3,000 sheep, with the exception of laymen on their own inheritance, who may keep as many as they please, but they may not carry on sheep farming on other pioperties.

1535.-. In this year, when the French urvigator Cartier visited the country which is now called Montreal, he found the town was situated in the midst of extensive corn helds.

1535-Captain Jacques Cartier, French navigator and explorer, in his visit to the St. Lawrence river, saw and admired the wild plum trees of Niorth America. 
15:35, - King Henry, VIII. of England had laws prssed for selection and mating for
the inuprovement of lorses and to elimlnate scruhs.

1510.-Beginning in April, Franciseo Vas que\% de Coronado, the Spanish explorer, penetrated to the country adjacent to the i.tite Colorado. where he found maize. Guinera coclis and peas in possession of the natives.

1541. - In the record of the travels of Francisco Vasque de Coronado in the ter ritory now comprised in the state of Kansas, he said: "All that way the plains are its full of crooked-back oxen (buffalo "Ls the Mountain of Serena in Spain is of sheep."

15.1\%.-At Farcelona, Spain, in this year, a recorded price for eggs was equal to twelve cents a hundred.

1512.-A plant named Shorghi (modern sorghum) described by Fuchius, of Belgium author of History of Plants.

15.17. - In the reign of Fdward, VI., King of England, exportation of horses to seotland was prohibited.

1548. - Tlie common jasmine (J. officinale) introduced into England from the East.

1549, March $8 \mathrm{th}$-Bishop Lattimer preached his famous "Sermon of the Plough" before the Court of King Edward, VI, of Fingland, and complained that. where formerly there were dwellings and inhabitants there is only the shepherd and his dog. He reproached the land owners with depopulating th country by turning cultivated farms into stock ranches.

1550.-The origin of the Iamakk rose is unknown, wut it was introduced into Europe from Asia Minor some time in the sixteenth century, and about this year.

1550.-The peach, which is a native of Persia, was considerably cultivate 1 in Britain about this time,

15.50.-De Re Rustica, first work on agrieulture, published by Conradus Heres bachius, being translation of ancient work by Columelia.

1550.-In this year Evlya Effendi,

Turk wrote an elaborate description of the Angora goat.

1551. - Konrad von Gessner, an eminent Swiss naturalist, established a garden of fruits and flowers. He published a history of annuals and classification of plants.

1551.-Bishop Scory, of Rochester, pre. sented a petition to the King of England, saying that now there are only "ten ploughs where formerly there were from forty to fifty." He said that the country population of England would soon be more like the slavery and peasantry of France than the ancient and godly yeomanry of England. The land owners found it easier to make money running grass farms than cultivating grain crops.

15.2. - The rravevine first introduced into Fngland from Flanders, First planting in the county of Suffolk.

1553.-The currant shrub was imported into England from the Greek island named Zante. The currant was originally named after the city of Corinth, which was an important Greek mercantile and exporting center.

1555.- In the great famine in England in this year, wild fitehes kept many farmers and others from starving. Fitches are the fennel thower, a coarse kind of pea, hard but nutritious.

1555.-In this year, in reporting his observations, Sir Ralph Lane, the English Administrator in America, said that the grapes of Virginia were larger than those of France, Spain or Italy. Sir Ralph Lane of France, Spain or Italy. Sir Ralp
was the first Governor of Virginia.

1562.-Tusser in his "Five Hundred roints of Good Irusbandry," says:

"Wife, into the garden and set me a plot

With stravberry roots of the best to be oot,

Such growing abroad, among thorns in the wood,

Well chosen anct picked, prove excellent goort."

1562.-Earliest planting of fruit by white men in North America. The Spanlards incer Menedez planted orange trees at St. lugustine, Fla.

1562.-Jesuit Fathers planted pears in region of the Great American Lakes.

156\%. The book, entitled "Five Iundred I'oints of Good Ilusbandry," by Tusser, was cecommended to be taught in English chools. It was written in verse.

1565. - Sir John Hawkins credited with introducing the potato in England in this

156:- Peaches introduced into England rom Persic.

166:-Quotation from Tusser:

First barley ere rye,

Then Pease bye and bye,

Then fallow for wheat

Is husbandry Great.'

1562. This is the year in which the linglish walnut is credited with arriving in England from Home, where it was called "the Nut of the Gods."

1564.-Accordinf to an article by Geo. C Husman, of the Department of Agriculture, considerable wine was produced from a lative grape in Florida as early as $\mathbf{1 5 6 4}$

1565.-Nicolo Monardes published writings on American plants, probably the earliest ceparate vritings on the subject. Issued in erial form in Spain.

1565.-In this year the Spanish colonies n Florida were visited by John Hawkins, an English captain, who said that twenty hogsheads of wine had been made in a ingle season from the wild grapes.

1565.--In a letter of this date Gessner, Siviss hotinist, mentions the IIusk rose growing in a garden at Augsburg.

1565. - Iarge importations of sheep in Florida from Spain. Supposed to be the

1565.-Menerlez founded a settlement at Augustine, Fla., the first permanent olony on this continent.

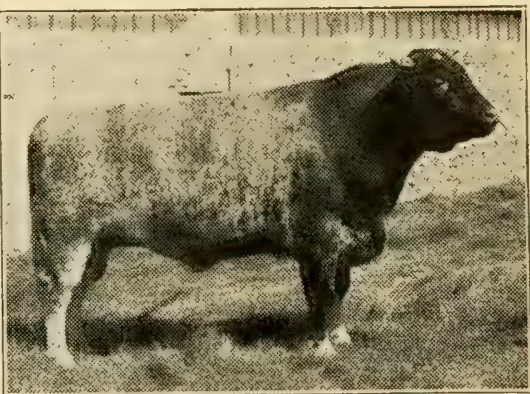

WHITEHALL MARSHALL - Champion Shorthorn bull.

156\%.Charles, IX King of France, issued aecres in resard to Paris slaughter houses and ordering improvements in butchering methods. The slaughter houses abutted on ihe urincipal thoroughfares, hordes of footsore animals impeded tratfic, the offal was ieft on the streets arid was washed by rains nto the river Seine.

15\%0.-Hemp and flax mentioned as being common crops in England, Buckwheat also mentioned as sown after barley.

15\%1. - The Festival of the Rose instituted by pope Pius, $V$, in thanksgiving for the rictory gained by the Christians over the Turks at Lepante.

1573. - The hollyhock introduced from Syria into English gardens.

1573.-Coffee, a native of Arabia, Felix and Ethionia, firsc introduced to the notice of Europerns by Ranmulfus.

1574. - Reynolde Scott, in England, puolished a treatise on the culture of hops.

1578.- "Whole Art of Husbandry" printed in England by Barnaby Googe, mostly transtion from the German. 
1580. Between this year and 1585 the Irish potato was introduced into Europe by the Spaniards.

1580.- Shorthorned cattle existing in Durham and Yorkshire, Lingland, from which the modern Shorthorns are in greater part descended.

1582. - The first record of the Musk rose having been cultivated in England is in Richard Hakluyt's writings, in this year who states that it was brought from Italy

158\%.--In this year, in England, in one of the southwest counties, a capon cost sixlence $(1 \%$ cents $)$, a calf five shillings (\$1.20), a firkin of butter seven shillins and sevenpence $(\$ 1.82)$, a cock (for fighting) fourpence ( $s$ cents), a pullet threenence ( 6 cents), a milch cow cost thirty (\$1.68), a horse twenty-two shillings $(\$ 5.28)$, a porkling twenty-eight-pence, or (\$5.28), a porkling twenty-eight-pence, or

1584.-Don Antonio de Espejo, sent by the Viceroy of New Spain, explored the Pecos river country and mentioned a great multitude of oxen or kine (buffalo) that fed upon the banks thereof, by which they iraveled for the space of 120 leagues, still meeting with "store of the said cattell.

1584.-Sir Walter Raleigh fitted out an expedition in Fngland and landed in America. The colony was called Virginia. As they did not cultivate the soil, they were starved out and returned to England the next year, where they introduced obacco.

1586. - In this year Sir Francis Drake is credited with introducing the potato in England.

1586. - On his return from Virginia, Sir Walter Raleigh introduced potatoes and tobacco in lreland. He had an estate at Myrtie Lodge, Youhal, county Cork. The potatoes were suitable to the climate anr flourished, becoming a great benefit to the island, but the tobacco growing met with poor success in Ireland.

1588.--Thomas Hariot, a returned colonist belonging to the Sir Walter Raleigh expedition to Virginia, published in London the first article ever written on Indian corn in North America. It was again published in Frankfort and illustrated by De Bry, a wood engraver.

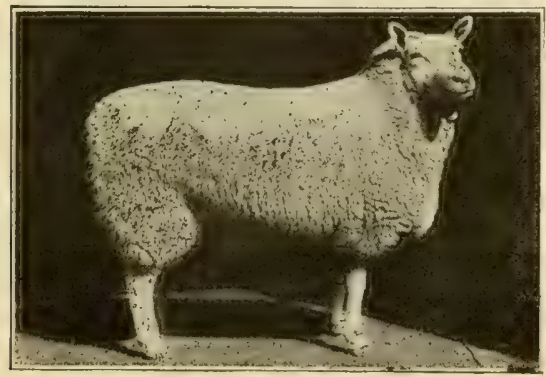

CFEVIOT FWF-Grand champion at the Louisiana Purchase Lxposition, 1904.

1588. - Origin of Cheviot sheen said to bn that sheep swam ashore from the wrecked ships of the Spanish Armada and escaped to the Cheviot hills.

1591.-The coffee plant scientifically described by Alpinus.

15!). - Sir Hugh Plat, in a book entitled "Jewel House of Art and Nature," makes usefu? observations on manures.

1594. - In this year, in Warwickshire, England, a farm laborer received fourpence ( 8 cents) a day, with "meat and drink," or eightpence to tenpence finding himself. food, or fourteenpence ( 28 cents) without food, or fourteenpence (28 cents) without
it: reapers, sixpence to twelvepence, according to whether they boarded themselves or not.

1596.-Gerarde speaks thus early of the white lily--the lily of the poets and paintbeing an ild garden plant.

159\%. - The caulillower known in England but very rare. mhe plant was mentioned hy a writer named Gerarde, and was supnoseu to have come from Italy.

1597.-The common and well-known lilae introduced into European countries by way of Constantinople.

1597. - In this year John Gerarde published his Herbal or General II istory of Plants. Born in 1545 and educated as a surgeon, his tastes led him to study the rultivation of plants. His garden at Hollorn (now in the center of London). Englancl, excelled any in that country. His book was ihe standard in botany for a hunc?red jeirs.

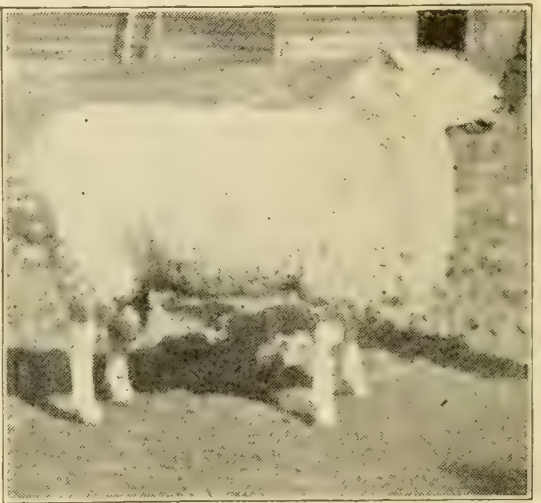

LEICESTER SHEFP-SANFORD. Weight, $\$ 20$ nounds heaviest ram exhibited. Fleece ecord, 26 pourds. Frand champion of the ,reed at the Louisiana Purchase Exposition, 904. Exhitited hy Alex W. Smith, of Maple Lodse, Ontario. Canada. Photogranh y R. I. Rngerson.

1598.-In this year Senor Juan Ornate started out from Zacatecas, in Mexico, to explore the country now known as New Mexico. He had 400 colonists, 83 wagons and 7,000 cattle. He founded Santa Fe.

1600.-Pohert Bakewell, of England, commenced the improvement of sheep, establishing a breel of Leicesters, also advocating grand urincipies of breeding by selection. He ils improved the Longhorn cattie ne Leicfstershire.

\section{THE SEVENTHENTH CENTURY.}

160\%.-Oats and barley first cultivated in merice in Gosnold's colony.

1602.--The first wheat was brought to this ountry by Jartholomew Gosnold and landed $n$ itn isliznil in Buzzard's Bay on the uthern coast of Massachusetts

160:- Beans were cultivated on islands of Massachusetts.

1604.-In this year M. I. Escarbot brought horses to Acadia, an island once a part $I^{\prime}$ French territory in America, and from there the Frencli who extended their settlement: into Canada in $160 \mathrm{~s}$ took the horses, whicis probably laid the foundation of what are now known as Canadian pontes.

1605. - Santa Fe (New Mexico) settled in this year by the Spanish. Don Juan de Ornate, of /jacatecas, in Mexico, was the originatror of the colony. It is the second oldest white settlement in the United Stateg

1607.-First permanent Fnglish settlement il America at Jaméstown, Va. Cantain Christopher Newport commander of the expedition. his companions being Bartholomew Gosnold, John Smith and others.

1607.--Sir John Norden printed a book called "surveyor's Dialogue," in England Sieaking of the famous Salisbury meadows. lie says: "When cattle have fed their fill. 
nogs, it is pretended, are made fat with the remnant-namely with the knots and sappe of the grass."

160\% - First recorded effort in this country at introducing foreign fruits by the Jamestown colonists in May of this year.

160\%. -Use of freezing mixtures of ice or snow in combination with salt, saltpeter or wher chemicai agents in use at this time in a small way.

160\%- - A company of English attempted to settle where is now Kennebec, Me., but returned to England the following year.

$160 \%$ - "Clouer Grasse, or the Grasse Honeysuck!e," (white clover), is directed to be sown wia!ogue.

1608.--The French at this time introduced cattle into Canada.

1608.--The James river settlers learned the cultivation of corn under tuition of the Indians.

1608.-Captain Newport sailed from Jamestown, Va., for England, carrying with him twenty turkeys, "the first introduction of that fowl into Europe."

1609. - First authentic record of a yield of corn produced in America by white men was forty acres in the Jamestown colony in Virginia.

1609.-A pamphlet published in London predicts that cotton would grow as well in Virginia a's in Italy.

1609. Sheep introduced into Virginia from England. Favages by wolves kept the flocks down to small numbers.

1609.-Wnglish horses landed at Jamestown, Va. There were six mares and one horse.

1609. - A book published in England by Butler, of Oxford, entitled "Feminine Monarchie; or, the History of Bees."

1609.-The London Company imported swine into Virginia, and they increased so fast that in 1627 the colony was in danger of being oxerrun with them, while the Indian's fattened thenselves on pork from ile hogs that had become wild from running at large in the woods.

1610.-Lord Delaware arrived in America from England and brought with him French vine dressers:- He planted vineyards o native grapes. He was Governor of Maryland.

1610. Cattle having become extinet in Virginia on account of the scarcity of food, another stock was brought from the West indies, and the penalty of death for killing them was enacted.

1610,-About this year King James I., o Engiand, purchased a celebrated Arabian lorse from a merchant named Markham,

1611. - First cultivation of wheat in Virginia was reporter in this year.

1612.-Oll of Rosés discovered by accident this year, according to Langles.

1614.-Plantings of imported apple and pear trees in New York One pear tree of this planting at Third avenue and Thirteenth street, New York City, until 1866.

1616 - - First known cultivation of tobaceo in the state of Virginia.

1617. - This is mentioned as the remarkable period of the first introduction of the labor of the plow in Virginia.

1618, January 17th-m patent was granted in England to David Ramsey and Thomas wildgosse for a machine to "plouglie grounde without horse or oxen, and to enrick and make better and more fertill as well barren peate, salte and sea sande as island and upland grounde, within sande, as island and upland grounde, within our Dominyon of Wales, etc, etc." It was the first patent granted in which the great Hower of steam for the purpose of assisting in the cultivation of the soll was applied.

1618.-In this year, at Epsom Downs, in England, the saying originated: "It is one ihing to take a horse to water and another to make him drink." It appears that during a drouth Henry Wicker, a herdsman, discovered water in a small hole on the Epsom commons, He used a spade to widen the ole and then discovered that neither he nor his stock could irink the water. This led to the discovery of the well-known mediine, Fpsom Salts.

1619.-Grapes mentioned in history as rowing at Jamestown, Va.

1619.--Negro labor first introduced into Grgini: Twenty purchased by tobasco lanters from a Dutch trading vessel.

1630.-Coaches as means of public conin England and Franse, slow in coming into genera

16:0, December 22d,-The Maytlower anded 102 pilgrims at P'lymouth Rock.

16:0.-The :Pilgrim Fathers found exensive plantings of corn in New England on their arrivat,

1621.-Edward Winslow wrote that in New angland "are grapes, white and red, and very sweet and strong also."

1621. - The Governor of Massachusetts equested the Indian Chief, Massasoot, to xchange seed corn, that he might judge which was best. The Indians selected the inest ears and taught the settlers how to 0 the same.

16:1. - Earliest known experimental cotton blanting in Virginia.

1621. - The Pilgrim Fathers began the cultivation of corn, manuring, as the Indians lid with fish "According to the manner of the Indians, we manured our ground with ,errings, or rather shads, which we have in sreat abundance and take with ease at our doors. An acre thus dressed will produce and yiold as much corn as three acres thout fish.

1621. - In this year 'The London Company sent "silke worm seede" to Virginia along with grapevines. This was the beginning of many attempts to establish a great silkgrowing industry in America.

1621, March,-Record of Plymouth Colony: They sowed six acres of barley and pease and set twenty acres of corn, making use of ten hushels which they brought from subcerranean storehouses of the Indians. In this work much assistance was rendered them by Squanto, a faithful Indian, who taught them how to plant corn, manure with fish, and hill it."

16.1--Eleven women emigrated from England to become wives of colonists in Virginia. The passenger fare across the cean was paid by 120 pounds of tobaceo for ach person.

1622.- - In New Fngland it is recorded at this time that the Indians made a habit of setting fire to the country twice a year, in the spring and in the fall, because it would therwise be overgrown with weeds and brush.

1622.-An chiserver at Plymouth Colony in this year said: "The chestnut, hazelnut, butternut and shagbark yielded contribuwinter."

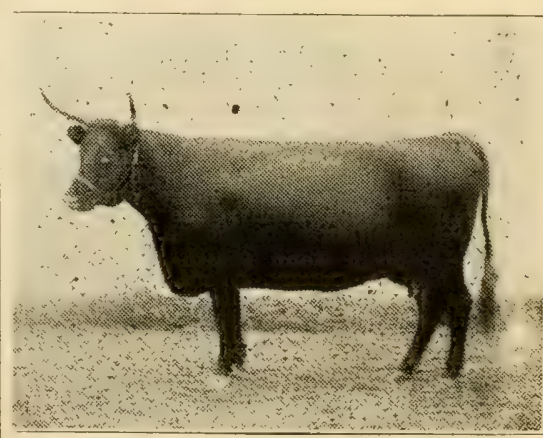

DEVON COW-PRETTY PET. The Devon breed of -cattle passes as a dual-purpose breed-good for beef and good for the dalry. 
PRETTY PET is a handsome example of the Devon: she was first-prize cow at the PanAmerican Exposition at Buffalo, 1901.

1623.-A few Devon cattle crossed the Atlantic ocean in the ship Charity; said to be consigned to a Mr. Winslow, of Massachusetts.

1623. - Demartment of Agriculture report says that about this time flax was introfuced upon the continent of America solely for the fiber. For a period of 150 years thereafter, or until cheaper cotton fabrics began to supplant linen ones, flax played an important part in the progress of the country, becoming, as it did, the basis of that famous household industry Whose home-spun products

1623.-New Iampshire settled by the English in this year.

16\%3,--Indefinite information concerning importation

1624. - Early settlers introduced sheel from England into the New England States.

1624.-An early importution of cattle to New Fingland, consisting of three heifers and a lull, having been made in this year, the herd had increased to twelve by 1627 , and in that year was divided into twelve lots. "These lots were drawn for," says

Russell, in Pilgrim Memorials, "affording the fir'st recorded cattle show in New Fingland."

1625.-Buckwheat flrst cultivated in America, on Manhattan Island.

1625. The Dutch Colony on the Hudson was supplied with all sorts of plows and agricultural implements.

1626.-Flax taken to Holland that was grown on Manhattan Island.

1626. - The Dutch bought the island of Ianhattan from the Indians for $\$ 24,00$.

1627.-First important cattle imports into New York state from Holland.

1627.-In this year only fifty Irackney cabs or coaches were in use in London England, as public conveyances.

162\% - John Speed, agricultural author mentions the excellent condition of cattle in Herefordshire, England.

1627. - Sir Anthony Ashley, of Wimborne, St Giles, Dorset, England, died in this year. He frst planted (improved) cabbages in England, and at his feet a cabbage appears ehiseled on his monument.

1629.- In this year six vessels arrived at Boston from Fngland, bringing with their other gools some twenty-five mares and stallions. In the same year a number of Dutch, Swedish, Danish and French horses arrived in the colonies of New York, Connecticut, Maryland and New Jersey.

1629.-The Spiderwort was one of the first native jowers to find a home in England, it having been sent there from Virginia about the year mentioned.

1629. - First attempt at hop raising in the United States made in Netv Netherlands, now New York state.

1629.-Plymouth Colony cultivated potaoes.

1620.-Rev. Francis Higginson, writing from Massachusetts Colony in this year, said that excellent vines were there and that the Governor had planted a vineyard, with great hopes of "encrease."

1629.-THIllam Wood, twriting from New England, said: "There is likewise strawberries in abundance, verie large ones, some being two inches about; one may gather halfe a bushell in a forenoone."

1629.-Captain John Smith, Governor of the Jame'stown Colony, wrote, saying: "One Mistress Pearce, of Jamestown, an honest, industrious woman, had gathered from her garden in one year neere an hundred bushels of excellent firges."

1630. - In March of this year the Colonial Assembly of Virginia determined the eash value of tobacco for the first time in history. The price was six pence, equal to twelve cents, per pound.

1630. - In this year wa's written a poem
Gy a New inglander, which shows how cable that early

Stead of pottage and puddings and custards and ples,

ur pumpkins and parsnips are common supplies:

We have pumpkins at mornings and pumpkins at noon;

if it was not for pumpkins we should bo undore."

1630 (about.) - Swedish immigrants introroduced sheep into New Jersey and Delaware.

1630.-Earliest record of pear tree planting in New Fngland was a pear tree in the garden of Gnvernor Endicott's house, in Boston.

1630.-Origin of the saying "Hobson's Choice." This adage has been handed down to us from the Seventeenth Century and had its origin in the eccentricities of one Tobias Hobson. This worthy was a carrier of Cambridge, England, who died in the year 1630 . In addition to his ordinary business he kept a stable and let out horses to the students at the university. He made it an unalterable rule, however, that each animal should have an equal period of work and rest, and would never let one out of its turn. Consequently, instead of being allowed to select the steed they most fancied, his customer had to take the one that s.tood next to the door. If it did not meet with their approval they had to go without a ride. Hence, the proverbial expression, "Hobson's Choice," used to signify a choice without an alternative.

1631.-Cattle importations into New Hamphire from Denmark arrived in this year.

1632. - Governor's Island, in Boston Harbor, Was granted to Governor Winthrop on colldition that he should plant a vineyard ox orchard unon it.

1033. - A list of vegetables grown in New Fngland before this year was given by a Mr. villiam Wood. He said also: "Whatever grows well in England grows well there."

1633.-In Virgina, in this year, tobacco inspection warehouses were established, in which th tobacco grown for sale was examined by Colonial inspectors, "who 'shall cause all the bad and ill-conditioned tobacco instantly to be burned, and the planter thereot' to be disahled further from planting any more of that commodite of tobacco."

1634.-Olives introduced into Southern colonies without much success.

1634.-Cecil, the Second Lord Baltimore stablished a settlement near the mouth. of the Potomac river

1654.-An act passed in the Irish Legislature against the cruel and common practice of plowins by fastening the plow to the tall of an $\mathrm{OX}$ o1. horse.

1635. - "Canadensium Plantarum," an lllus. trated book issued by Jacques Cornutus, is generally supposed to be the first published work on American plants.

1636.- Poger Williams settled what is ow the state of Rhode Island.

16:36. - At this time in the colony of Massachusetts Bay a red calf came to be cheaper than a black one on account of the sreater liability to be mistaken for a deer and killed by the wolves. This is from Kettell's Chatter on Agriculture in the United States.

1637.-At this date only thirty-seven piows were in the colony of Massachusetts.

1639. - It was reported that one man made 500 barrels of cilier in New York state, indicating earlier general planting of apple urees in this country.

1610. Pork packing in barrels as an industry said to have begun in this year at Salem, Mass.

1610.-William Kelft Governor of New Netherlands, erected a private establishment on Staten Is]and, "which produced the first beer made in this country," says an duthority.

1610.-Tobaceo first reported a's being grown in New Fingland colonies.

1641.-Newmarket, England, as a racing eadquarters dates from this year. 
1644.-The Haymarket of the city of London established in this year; abandoned in 1830 .

1645.-Sir Richard Weston, Ambassador from England to Bohemia, credited with first introducine "the great clover" in England, and turniog also. He was a useful writer on agricultural subjects.

1646. - In this year Joseph Jenckes, of Lynn, Mass., a native of Hammersmith, in England, was granted a state patent privilege for inventions, making mills for the manufacture of "sithes and other edge" tools for ye more speedy cutting of grasse."

161\%. - The apple recorded as grafted on the wild stocks of Virginia.

1617.--Iice muture in the United States began with half bushel of the grain sent over from England to the Virginia Colony in this year, from which a yield of sixteen unshels was obtained. The industry afterwards gave way to tobacco gruwing.

1647. - Exportation of wool first prohibited from Great Britain: also in 1660 and 1668 .

1618. - An apple tree planted by Peregrine White, the first white child born in New England Says the author of "Pilgrim Memorials," written in 1655: "It still produces apples, and the orchard in which it grows Is now owned by his descendant's, near the int which he occupied in Marshfield."

1648. - Ioys first raised in Virginia.

1648. - Rye as a field crop first grown in America in New England.

1649._- "The Improver Improved," an agr' cultural work by Blythe in England, recommenis that turnip cultivation should be extended from the kitchen garden to the field as food for stock.

1650.-Hartleb, an Finglish writer, men. tions the practice of steeping and liming 1650.-French Work on Agriculture published by Oliver de Serre's.

1650.-The "Thite Turk," 'Turkish stallion, owned by Mr. Place, stud groom to Lord Protector Cromwell, credited with being one of the originators of the thoroughbred horse.

1650.-A pearl barley mill invented in Germany.

1650.-Horses imported into South Africa from the island of Java by the Dutch East India Company.

1652.-Cape Colony, South Africa, fir'st colonized under Van Riebeek. The sheep which the European discoverers found in Cape colony were the flat-tailed sheev. Cape Colony were the flat-tailed sheep. variety.

1653.-Van der Donck, the travcler, wrote that by this vear the Dutch settlers of New York had already blonming in their rardens white and red roses, eglantine, dî̉ferent varieties of tulips, violets, white lilies, anemones and marigolds.

1656. Covent Garien market, the great wholesale fruit and vegetable market of the city of London, originated about this time by the construction of wooden sheds and selling stalls, Covent Garden was in earlier days the garden of Vestminster Abbey, when it was properly named Convent Garden.

165\%.- The exportation of horses from Virginia was prohibited in this year.

1660.--Earliest record of the use of mineral salts for increasing the yield of crops appears in a work entitled "A Discourse Concerning the Vegetation

Plants," Tt was read before Gresham College, in England, by Sir Kenelm Digby.

1660.-Ray, a writer, made a tour of the southern counties of Scotland. He said: "We ubserved little or no fallow ground in Scatlind: some ley ground we saw, which they manured with sea wreck."

1661. - The Dutch East India Company sent trvo pounis two ounces of Chinese tea to the King of Fingland as a rare and valuable offering. The first known tea to arrive in England.

1662.-First statute for levying tolls at turnpikes to make or repair roads.

1662.-The Dutch colony on the Hudson river. New York, added "a tirst-class wheel plow" with its pulleys, etc., to the stock of asricultural implements at a cost of sixty forins.

1663. - In this year, when the second harter was eranted to Rhode Island by Charles II., King of England, it contained in inducement to anyone who would plant vinevard.

1665. - Minister Colbert, Prime Minister o Louis iV., éstablished government stud

1669.-The "Byerly Turk," a Turkish stallion, ridden by Capt. Byerly, of the English army, at this time, is credited with reing one of the foundation stock of the English Thoroughbred.

1670.-Permanent settlements in the tract f land south of Virgina, called Carolina, honor of Charies II., of England.

167\%.- Tohn Josselyn published a book entitled "New CMgland IRarities," discovered in birds, beasts, lishes, serpents and plants country.

1674.-Malpighi publishes a paper on the structure of plants.

1676.-Tax derived from tobacco export this year amounted to $£ 120,000$ English money, or, in round ngures, $\$ 700,000$ in merican money of the present day.

1680.- It is sald that peaches were intro duced ahoit this timie into America by the arly sett?ers.

1681. - In Houghton's "Collections on Husbandry and Trade" appears the first notice of turnips being eaten by sheep.

168:- William Penn established the first ettlement in what is called Pennsylvania.

168: - The Imperial stud of Russia reeived importations of Arab stallions, whici caused a deciled improvement in the horse of that country. It was by direction of the Great.

1683.- Sheep raising in Pennisylvania dates from about this year.

1685. -This year witnessed the beginning of a small French colony in Texas under the Chevalier LaSalle, who landed on the shores of Matagorda Bay. The occupation was brief.

1686. - William Fitzhugh, in Virginia, cescribed his own plantation and mentions a large orchard of about 2,500 apple trees, inostly grafted, well fenced with a locust

1688.--Persian-Arab horses introduced into South Africa by the Dutch East India Company.

1688.-An English writer, Rav, mentions eventy-eight varieties of apples.

1688. - St. Marys, the oldest settlement in Michigan, established by the Jesuit Missionaries.

1690.-The first work treating of roses with any degree of method published. It was that by LaQuintyne, and issued in Paris.

1090.-Potaloes were beginning to attract notice in Scotland. "The potato is a baccif. erous herb, with esculent roots, bearing vinged leaves and a bell tlower.

1690.-The Mango introduced into hothouse cultivation in England from the East Indies. 1690. - At this early date Boston, Mass. was doing quite a trade in packing and uring pork.

1691. - The Phlox, an American genus of plants, mentiuned in a work published in iondon by Plukenet, a writer living beforu he time of Linnaeus.

1691. Experimental proof of the sexuality of plants published for the first time by Canerarius, a German botanist. He was in charge of the gardens at Tuebingen.

1694.-A ship captain, seeking shelter in the harbor of Charleston, S. C.. presented Thomas Smith, Governor of the province, with a sack of rice. From this the rice industry of the present was established.

1695.-In this year John Houghton, an Englishman, writing of dairy subjects, speak's of the Irish as rotting their butter and burying it in bogs. The burying of and burying it in bogs. The burying of 
storing in lime of need, or to hide it from invaders, or to ripen it for the purpose of developing flavor

169\%- - First agricultural work in Scotland printed under the title of "IHsbandry Anatomized; or, An Inquiry Into the Present Manner of Felling and Manuring the Ground in Scotiand," by Donaldson.

1700.- Trustworthy records of the breeding of the thoroughbred horse were first begun in the stud book by Messrs. Weatherby

\section{THE FIGHTEENTI CENTURY.}

1701.--Jethro Tull, a gentleman of Berleshire, in Ensland, adopted the system of sowing his erops in rows or drills so wide
inart as to admit of tillage of the intervals lioth by plowing and hoeing.

1704.- The beppermint plant mentioned and named by Ray in his book, "Historia Plantarium

1706. - Practice of cutting clover green and giving it to cattle, now called soiling, menlioned as being a common practice at this lime

1710-- First attempt to grow lig trees in the state of Calfornia.

1712.-Naraldi, of Nice, invented glass be-hives, enabling naturalists to study the in-dcor proceedings of bees.

1714.- - Father Iirtoux, a missionary among Chine'se published a description of a Tartarian plant called Ginsens.

1716. - In this year, through efforts of Iather Iafitau, a missionary amongst the Canadian Indians, the plant now known as American Ginsen was discovered near Monireal.

1716.-Thomas Fairchild, an English rardener, crossed the Carnation with the Sweet Williant. This is the record of the lirst hybrid (mixture of the species) in flowers.

1718. -The English thoroughbred stallion Bulle Rock foaled in this year was imported into Virginia by Patton \& Gist in 1730, and is said to have been the first thoroughbred to arrive in America.

1719.-An inundred families from Ireland having settled at Londonderry, N. H., they introduced the foot spinning wheel, the manufacture of linon and the culture ot potatoes.

1720.- Joseph Foljambre, of Rotherham, Fingland, took out a patent for a plow with moldhord and landside of wood sheathed with iron plates. the share and coulter being made of wrought iron with steel edges.

720.-In this rear a Galloway horse ivas foaled at a village near Haddington, in Fcotland, which lived to be sixty-nine years ild. Wilkes' Spirit of the Times, authority for this statement, mentioned him in later years as being eleven hands high, and that he trotted clever!y right up to a few weeks of his death.

1:21. - First efforts to grow cotton in Virginia date from this year.

1723.--Iord Bellhaven, of Scotland, published a book which he described as a "good, easy method of husbandry."

1723. - Mr Alstroemer an enterprisin: Swedish farnier, introduced Merino sheen into his own countrv. He encouraged the vovernment to e'stablish an agricultural school, which ofierer premiums for Spanish Merinos and the best wool.

17:3. - "Society of Improvers in the Knowledge of Agriculture in Scotland, rrganized. First of its kind in the United Kingdom.

1724.--Tie horticulturist Dudley said that Indian corn is of several colors, as blue, red and yellow: and if they are planted sept rately ly thamselves they will keep their own color: but if they are planted one color near another they will mix and interchange their colors.

1724.-Godolphin Arabian, the most noter of all the Eastern thoroughbred sires. fnaled in this year. He was imported into England from France by a Mr. Coke. This great stallion was said to have actually becn a catr horse on the streets. of Paris. Colonel S. D. Bruce, authority on the thoroughbred horse, said of him: "He unquestionably contributed more to the breed of thorougl ureds than any stallion either before since his time.

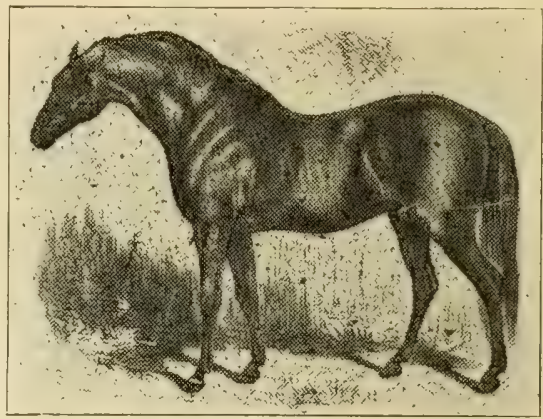

GODOLPHIN APABIAN. - The thorough lirefl horse that worked as a cart horse in I'aris and was discovered in time to be the most viluable foundation sire of the breed.

1\%26.-A village near Boston, Mass., l'eported making 19,000 barrels of ciler.

17\%6.--The horticultural writer Dudley, in is paper in the Hhilosophical Transac tions, said: "Our apples are without doubt ds rood as those of England and much fairer to look to, and so are the pear's; but we have not all the sorts."

17:7. - The loss rose was introduced into Enrland from Holland in the sixteenth cen tury, and is first mentioned by Miller in the year given. Miller supposed it to be a sprout of the Provence rose, which opinion as heen confirmed by modern botanists.

1727. -Hale's work published on respiraion of plants and formation of sap.

17.28. - The first botanical garden in the Inited states founded by John Bartram on the banks of the Schuylkill, not far from hiladelphia.

1 198.-.-In this year mention is made of "little machines which, being played by the motion of a wheel, the cotton falls on one side and the seed on the other, and thus they are separated," a primitive cotton-gin.

1730.-In this year the first English cotton-oil mill was erected in Gloucester. The eily of Gloucester is one of the im portant centeis of enterprise in the west of Bristol, which is in the same county.

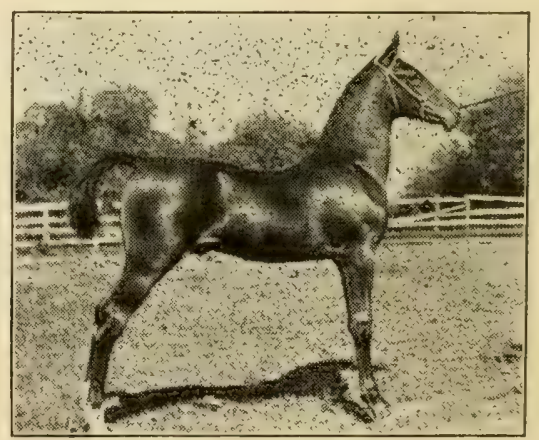

JUBILEE KING-SADDJE COLT. Foal of 1911. Already winner of first prizes at leading Blue Grass-Fairs. Bred and owned by J. F. Barbee, Millersburg, Bourbon county, Kentucky.

1730.-The Jlain-gaited saddle horse, without education, developing at this time into the five-gaited saddle horse. 
1731.--Spealing of the tomato, Philip Miller, in his Gardeners' Dictionary, says: "The Italians and Spaniards eat these applos (love apples) a's we do cucumberswith pelper, oll and salt-and some eat tilem stewed in sauces."

1731.-Iorse-hoeing IIsbandry published liy Jethro Tul!, of Berkshire, England.

173\%.-Iwor IBichard's Almanac first pub lished by Benjamin Franklin at Philadelphia.

1732,-John Kirby, traveler in England, writing of the Sulfolk led Polled cattle districr, said that the butter "was justly esteemed and the pleasante'st in England."

173:- In Maryland tobaceo was made legal tender at the rate of one English benny (two cents) per pound for all debts, including customs dues, the salaries of state wlicers and ministers of the gospel.

173:- - Justice Dudley, of Massachusettis. writing in this ycar, says: "An onion ret int for seed would rise to four feet nine feet."

1735.--The Fompone roses found growing wild by a gardener of Dijon, in France while cutting wood on a mountain near the eity.

1735.- - A stallion named Old Traveler, owned by Mr. Osbalde'ston, of North Ens= land, ancestor of Cleveland Bast.

1737.-The Studley bull dropped in this year became one of the first great stock setters of the shorthorn breed.

1\%3\%. Hugh Orr, a Scotchman by birth, arrived in Massachusetts and erected a trip hammer at Bririgewater for the manufacture of scythes and axes and acquired a wide reputation.

1740, The Tarpan, a IRussian horse, considered as being the wild ancestor of European horses, described by Guelin as a mouse dun in color, with dark points, short, crisp mane, with a short, bushy tall.

1740.-About this time James Small, of Berwickshire, in Scotland, first introduced the plow with the cast-iron mouldboard, still using wrought-iron shares.

1741.--Jolly Roger, a thoroughbred stallion, was foaled in this year. He was known on the English turf as "Roger of the Vale" He was the first horse that gave distinction to the racing stock of Virginia, where he was imported and commenced service as a sire in 1748 . He was by Roundhead, who was by Flying Childers, who was by Darley Arabian, 'The rlam of Jolly Roger tras not horse in his day.

1742.-The Baldwin apple, a chance seedling, sprang up this year on the farm of Mr. John Ball, in Eastern Massachusetts, ind bruught inte seneral notice by a Colonel Baldwin, who named it.

174:. - Iereford cattle improvement began vy Benjamin Tompkins, the elder of Canon Pyon, Herefordshire, England.

174\%. ML. Dubreuil, a planter of New orleans, invented a cotton gin, which was so far successful as to give quite an impuls io cotton raising

1741.-William Ellis, agricultural writer commended Iolderness cattle of Yorkshire for wide hags, short horns and large bodies.

1745.-Suffolk Punch horses famous for draft qualities. Norman stallions on Suffolk mares credited with the production of the hreed.

1745.-.- Beet-root sugar discovered by Margeral, a German chemist.

17.17.--James Elliott, a clergyman of Conrecticut, mublished a series of valuable essays on "Field IIusbandry."

1747-Agricultural speds first sold commercially in the United States about this time.

1747. "Memoirs on Wool," first publica tion of its class in Great Britain.

1718.-Rev. Jared Eliot, in a hook on farm hushandry, urges the growth of clovel for the reason that an acre of it would produce two bushels of seed, worth thirtyfive pouncls in the currency of that period.

1748. - In this year the Province of New
Jeisey passed a law requiring that trotting and pacing races be held only at Fairs.

1750.-First act of Parliament for collecting tolls on the highway of Scotland.

1750 (about).-Iames, the VIth. Duke of Hamilton, introduced a Flemish stallion for use of his tenantry in Clyde Valley, Seotland. This is said to be the origin of Ciyclesdale horses, but is disputed.

1750 (about). The commercial history of the peppermint plant hegan at Mitcham, is Surrey, Fngland.

1750. - Red clover known to be grown in rhode Jsland as early as this year.

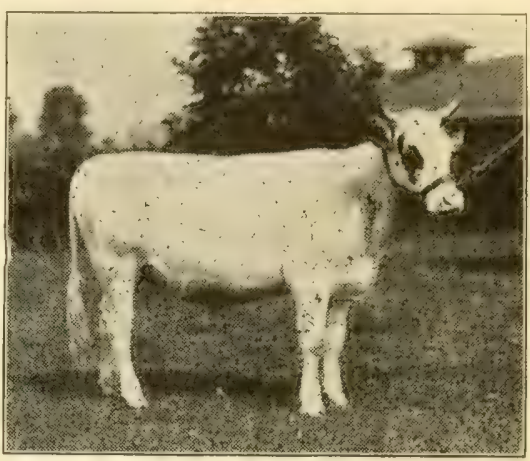

WILLOWMOOR BROWNIE-AYRSHIRF HEIFER Champion junior female at the National Dairy Show of 1911: daughter of Netherhall Brownie. 9th, world's champion Ayrshire cow. Bred and owned by Willowmoor Farms, Redmond, state of Washington.

1750.-About this time the Earl of March. mont purchased from the Bishop of Durham and carried to his estates in Berwiclshire, Scotland, several brown cows spotter with white. These vere the foundation ows of the Ayrshire breed of cattle

1750.-A herry having a pleasant pinepple-like aroma arrived in England from thili, South America, under the name of Pine strawberry. Credited with being imrover of wild berries.

1751.- Jesuit Fathers brought to Louisi ina samples of sugar cane for the purpose of adding to the resource's of the colony. his is now called "Crenle" cane

175\%.-Lightning conduetors first used for rotection of buildings.

175:.-The French government offered to burchase all the tobaceo raised in the province of Louisiana at a price equivalent en cents per pound.

1753.-The year usually taken as the beginniug of botany. Linnaeus grouped all the tulips, which he named under the classification of Tulipa Gesneriana.

1754.- In this year a Gallowas horse owned by a Mr. Crocker went an hundred miles a day for three days over the Newmarket Course in England and showed no distress. The Galloway was a hardy cob horse, the breed originating in Scotland, but is now extinct.

1754. - The best known of the Cape jasmines (which are not relater to the true introduced into England from China in this year.

1755.-From silk manufactured near Charleston, S. C.; in this year, three dresses were made in Fingland-one presented to the Princess Dowager of Wales, another to Lned Chesterfield, and the third to a erson, name not given.

1756. Marggraf, a German chemist. found the wugar beet contained only 1.5 per cent, of sugar, which is increased to an average of 13 per cent. by selection and mproved methods of cultivation.

1759.-First sugar house equipped with machinery erected at New Orlean's by
Dutreuil. 
1759.-The Bird's-foot violet was sent to the Apothecaries' Gardens, at Chelsea, near Iondon, as early as this year-probably by botanist, who sent many plants to England.

1760.-Commencement of memorable improvement in British agriculture.

1760.-The cow "Tripes," Shorthorn cow, hought by Thomas Hall, in England, earliest recorded cow of the Shorthorn breed.

1760.-First known commercial nursery in this country establi'shed by William Prince, of Flushing, Long Island, Pioneer of the industry, and published a catalogue of fruits.

1760.-MeCullough's Statistics of the British Empire records that in this year William Dawson introduced the custom of plowing two horses abreast with lines.

1760.-In the list of flower seeds published in a Boston newspaner advertisement this year are those of the marigold, sensitive plant, branching larkspur, white and yellow chrysanthemum, sweet peas, tall hollyhock, pink, Sweet William and French honey suckle.

1761.-The first known veterinary sehool established at Lyons, France.

1761.-First exact knowledge of hybrids obtained from a work by Koelreuter. scientist.

1762.-Fahrenheit used ice and salt mixture in fixing scale for the thermometer which bears his name.

1763.-Bartram in his "Travels" mentions having seen in this year near Mosquito Inlet, Florida, a ridge a half mile wide and forty miles long, which was one dense orange grove.

1763.-Nathaniel Bird, a book dealer. artvertised in the Newport ( $R$. I.) Mercury that he had garden seeds for sale just arrived from England. This is one of the earliest records of seeds being for sale.

1763.-In this year Laclede, Maxon \& $\mathrm{Co}$ estahlisher the first fur-trading depot at St. Louis. Mo. The brothers Auguste and Pierre Chouteau were connected with it. In those days the farmers tributary to St.Louis were hunters and 1 rappers.

1763. - In his book entitled "The History of the Jersey Cow in America," by Valancey E. Fuller, he said: "From the evidence I think it may be claimed that as early 1763 the purity of the Jersey cattle breed was a subject of great care, and it hay been scrupulously guarded till this day. ween scrupulousiy guarded the possible exception of an isolater with the possible excep

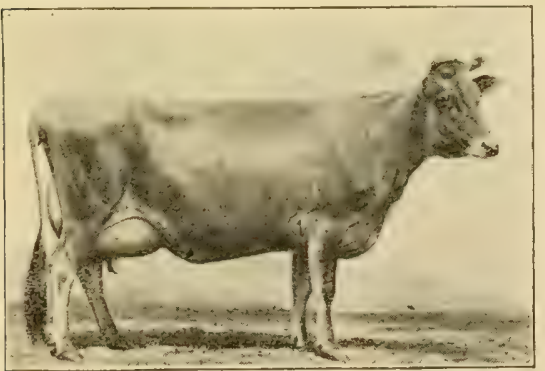

TERSEY COT-MATY ANNE OF ST. LAMBE:RT. 36 pounds 12 ounces of butter in one week: $\$ 36$ pound's in one year. Owned at that time by Valancey E. Fuller, of Hamilton Ontario, Canada. From Schreiber photo, 1882.

1761.-Alexander Garden, Scotch scientist, of Charleston, $S$. C published an account oi pink-root, the use of which as a vermufuge he had introduced. The botanisa genus Gardenia was named in honor of Mr. Garien.

1764-Giden TVelles announced in the Newport (P. I, ) Mercury that he had some choice Connecticut onion seed for sale.
1764.-Mr. Dawson, of Frogden, believed to be the first in scotland to grow turnip. for stock to a large extent.

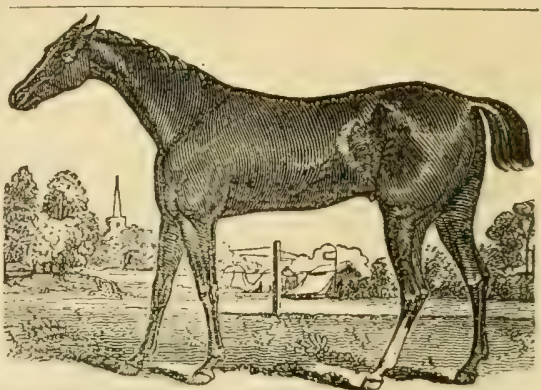

ECLIPSE - The Thoroughbred.

1761. - Eclipse foaled during the eclipse of that year: the most wonderful horse ever produced on the English turf; bred by the Duke of Cumberland; got by Marske, a granrison of Bartlett's Childers, out of sipiletta. "He puffed and blowed like an otter and galloped is wioe as a barn door." tivrence.

1761.- - Improved cotton-spinning machinery invented in England by Hargreaves.

1761.-First grephhouse on modern plans in this country constructed in New York.

1765.-The London (England) Society of Arts awvarded a gold medal to Benjamin Gale, of Killingworth, Conn. for a dril blow, the invention of which was claimed by Benoni Hilliard, of the same place.

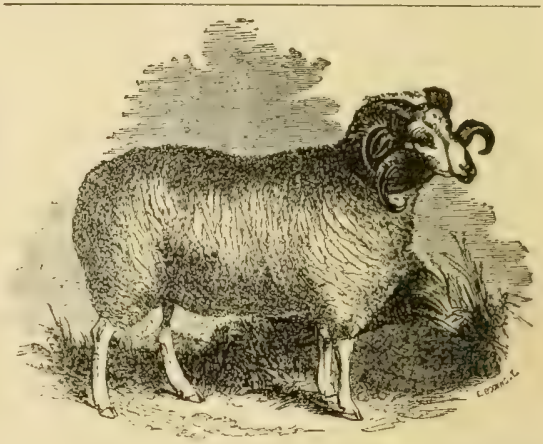

A SAXONY MERINO RAM. - A picture presenting this fine-wool Merimo breed, which at one time was a rival of the represents a ram of the early importations from Saxony.

1\%65.-Genrge Washington reecived a pair of blooded pigs from the Duke of Bedford, itled Bealford breed.

1765 - Merino sheen introduced into Germany iy grant of the King of Spain to the Filector of Saxony.

1765.-Saxon Merino sheep originated Ly flock of 300 Spanish Merinos 'sent by King Louis, $X T^{\prime}$ of France, at the request of his brother-in-law, Prince Xavier.

1766. - In this year samples of home-made cythes, shovels, spades, hoes, etc. were aid before the Society of Arts in New York and apliroved.

1766.-John Wynn Baker, of Kildare, in Ireland, commenced a system of ruralaconomi experiments and showed by actual experiment that the saving effected by the irill and horse hoe amounted in fifteen years to the fee simple (value) of all the cultivated lands in the kingdom.

1766. Field seeds first advertised in the New Ingland Gazette.

1767.-William Dunbar, a New England gardener alvertised seeds for sale as foilows: Peas and beans, 30 shillings per 
yuart: Strasburg onions and orange carrots, 25 shillings per ounce; early cabbage, 40 shillings per ounce; and "Collillower," 6 pounds per ounce. Ho also sold llower seeds.

1767.-M. Burinf, a Berlin merchant, lais a plan betore the King of Prussia, which ied to the organization of Land Mortgage Associations in Germany, the first organized or Brandenburs in 1850 .

1767.-In the Poston Gazette of this year six out of twenty-six advertisers were dealers in seeds.

1767.-Discovery by surengel of fertiliz: tion of plants.

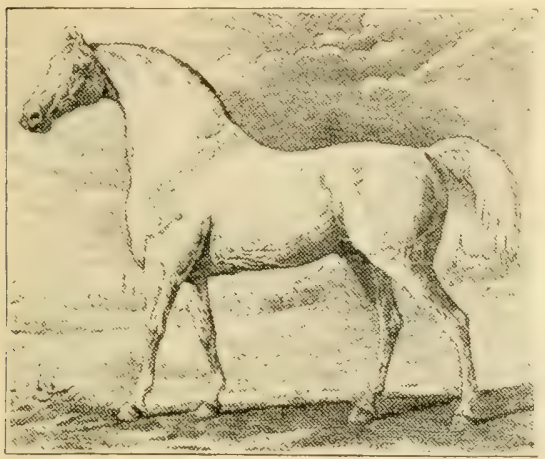

ENGLISH MAMBRINO-Thoroughbred.

1768. - Finglish Mambrino, a grey horse, sire of Messenger, was foaled in this year. Mambrino was a thoroughbred, and is the fountain head of the Imerican trotter. His son, Mressenger, was reputed as being the best horse ever brought to America.

1768. - This is the date generally agreer upor when the father of Hugh Watson, of Keillor, Scotland, first began gathering the cattle which were afterwards known as the original herd in the establishment of the Aberdeen-Angus breed.

1768.-Messrs, Culley settled on the Northumbrian 'side of the river Tweed. Great improvers of agriculture in border counties of England and Scotland.

1769.-Wdward Antill, of Monmouth, N. J., wrote the first American treatise on the grapevine.

1769.--The French settlers of Kaskaskia. southern Illinois, made 110 hogsheads of wine from wild srapes.

1769.- "Eclipse first, the rest nowhere." Eclipse first on turf this year, and for seventeen months won every race, closing his career by walking over the Newmarket course for the King's plate. His full speed was never tested, no horse ever having put it to the proof.

1769.-Olive trees planted at San Diego, Calli., still in bearing.

1769. - First investigation of pleuro-pneumonia in cattle by Bourgelat, the founder of veterinary schools, brought about by prevalence of the disease in Europe.

1770.-First plantings of grape at the Míssion ot San Gabriel, in California.

1730.-The popular Bartiett pear originated in England, it being propagated by a nurseryman named Williams; but having been disseminated in this country by Enoch Bartlett, it thus acquired its new name.

1771. - The great fringed orchis first made known to botanists through D. Pitcairn, who introduced it into the Kew gardens from Newfoundland.

17\%1.-Silk culture begun in Pennsylvania and New Iersey. It was interrupted by the Revolutionary War, and only revived in a small way after the treaty of peace.

1771.-Baron William Stiegel, who came to America twenty-one years before, gave the land for in church at Manheim, $\mathrm{Pa}$, this clause being in the indenture: "Yielding and onying therefor unto the said Henry Willam stiegel, his heirs and assigns, of the said Lown of Manheim, in the month of June, yearly, forever hereafter, the rent of one red rese, if the same shall be lawfully "temanded."

17\%2.-Priestley's treatise on breathing of bants issued in this year.

17z:-To Mrs. Ifartin Logan, daughter cf Robert Daniel, a Governor of North Carolina, is accorded the credit of publishing the lirst Ameriean treatise on garclening, which was written in her seventietl year.

17\%:--In Philadelphia, this year, Petelial Webster sold clover and duck gra'ss seed, heing one of the earliest in the red busines: in that eity.

177\%.- Nitrogen discovered by Rutherford in this year.

1773.--James Vaux, of Pennsylvania, imported clover seed from England because it was diflicult to obtain in America.

1753. - One of the early veterinary colleges established at Copenhagen, in Denmark.

17\%3.-Spanish sheep introduced on the Pacific coast of the United States; same Find as in Florida.

1773. - An iron plow was presented to tho Society of Arts in London, England, by a Mr. Brand.

1784.-During the Revolutionary War. Kinsey Borden, of St. Paul's Parish, South Carolina, invented a roller gin for the cleaning of long-staple and silky cotton, of which he was a large grower.

1775.-Empress Maria Theresa of Austria imported several hundred Saxony Merin. hlieep and placed them in Hungary at Merepail. Where an agricultural school veas (at)livilect.

1775. - The Cherokee rose, a Chinese species, known to have been cultivated at this time in the Southern states.

17.5.-Improvement in cotton-spiming machinery by Dr. Cartwright in England.

175.- Bartram's tree orchis, the first of its kind found in the Middle States, introcluced into Fothersill's gardens, in London. it having leen discovered in Florida a year or two before.

1775.- -James Jonghead advertised seeds in J'hiladelphia, 'saying that he kept "a quantity of the largest kind of collyilower seed, found on trial to be extraordinary

1775.-Count Orloti Tschismensky a lover of horses, inuported the grey Arabian stallion Smetanxa, and, crossing on Danish, butch and English mares, originated the reed of Russian trotters.

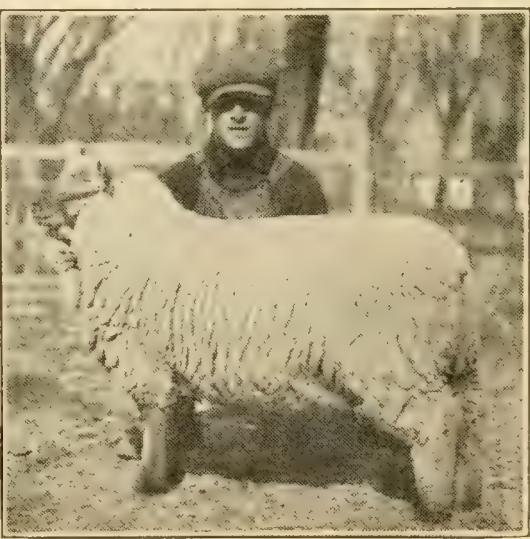

SOUTHDOWN IVETHER-GRAND CHAMPION, WESTERN NATIONAL SHOW DENVER, COLO., 1912. Exhibited by the Agricultural College, Fort Collins, Colorado. 
1775.--Improvement in Southdown sheep began about this time.

1775. - The first Austrian veterinary coilege ésiablished at Vienna.

1776. - The first artificial road in America was built in this year, from Philadelphia to New York.

17\%6.-In New York City, Samuel Deall, dealer in merchandise on Broad street, hejt a general assortment of seeds, including rerl clover, grass and "Saintfoine," for inprovement of land.

1776. - M. de Trudaine introduced Merino heey in France.

$1 \%$ 6, July 4.-Declaration of Independence.

17\%6. - The famous French nurseries at Ussy, afterwards acquired by Levavasseur \& Sons, established by Mons. Turgot, Comptroller General of France under Louis XIV.

177\%.-Poll tax levied for Baltimore ounty and city fixed at 17: pounds of tobacco. Une of the latest payments of axes in produce.

17\%7-Highland (Agricultural) Society cotland instituter

17\%7.-Fath anil West of England (Agricultural) Society estabished.

1\%7. - Large importation of Suanish Itrino sheep by the people of Saxony.

17\%7.-.John Bartram, born in 1699, died $n$ this year. He was called the "Father of Americain IBotany," He founded at Kingesinc the Grst imerican Botanical Garden and published many valuable writings on botarica! subiects.

1789.-The inhahitants of New England ohtained their tirst sweet corm from the indiuns in this year.

1779.--In this year the expedition of General Sullivan against the Six Nations in the Genessee country, New York, ascertained that the Indians harl ficlds of corn, and farclens of beans, peas, turnips, cabbages, melons. carrots, parsnips and potatoes.

1779.-Womatoes first used in catsup - in Orieans cibout this time.

1'79.-An early sweet corn introduced into Connecticut by an officer of the army reLurning from ar expedition against the luans in the Genessee country.

17\%9.- Tmprovements in cotton-spinning machinery in England by Compton.

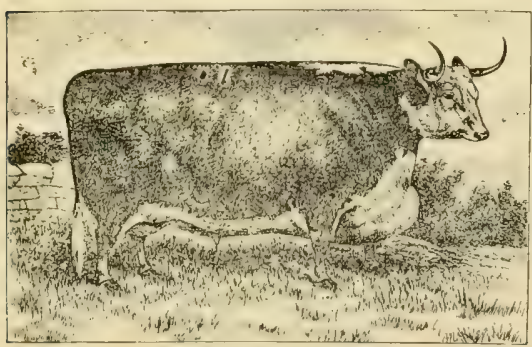

The Sntithfield beef champion.

1739--J H Campbell, of Charlton Kent, England, red and exhibited a famous Heroord ox at Greenwich. Live weight, 3,36 lounds: fore guarters, 1,016 pounds; hind fuarters, $\$ 96$ pounds: aressed weight, 1,912 pounds.

1780. May 1 th. -This wa's the first Derby Day in lugland. The race was won by Dioned. the property of Sir Charles Buin nury. All the competitors were colts. The distance was rne mile.

1780-Imuprted Messenger (a thorough ired), foaled in 1780 , imported to the United States in $17 \mathrm{SS}$ and died in 1808 . He Was of Arahian lescent. First in list of original sources of American trotting blood. Great-

1780.-William Pitt, of Pendeford, England, invented a reaping machine suggested by the description of Pliny and Palladius.
This was described in Young's Annals of Agriculture in 1787

1780.--Practice of drilling and horsenoeing crops introduced into Northumber

1780.-Mr. John Fllman, of Glynde Farm near I,ewis, in Sussex, Fngland, commenced breeding and improvement of Southdown heep, continted fifty-two years.

17x:--The Mango reached the West Indies from Brazil and soon became natur alized.

1783.-Iondon Society for the Encourage ment of Arts, Manufactures and Commerce called public attention to the existence ani value of cotton-seced oil.

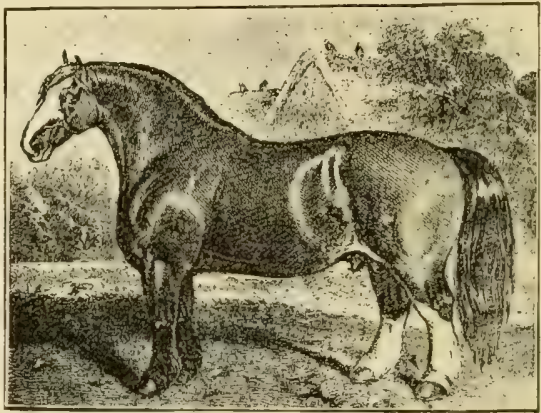

A Clydestale stallion.

1783.-Exhibition of stallions at Edinburs, Scotland. Highest prize won by "Blaze," first hoise causing marked improvement in Clydesdales.

1783.-First Gough \& Miller Shorthorn cattle importation via Baltimore to Virginia.

1783, September 3d.-Peace in Amerik's after eight years of war for independence.

178....."Huhback," a great foundation bull of Shorthorn family, bought by Robert Colling and $M r$, Waistell of Mr. Fawcett, near Darlington, England. This bull was the vreatest factor in Shorthorn cattle improvement. Had been used berore the discovery of his merits for service at one 'shilling per'

1784...-Plow with cast-iron mold board and wrought and cast-iron shares invented by James Small, of Scotland.

1781. - David Landreth established himself near Philadelphia in market gardening, nursery and seed-growing business.

1784, A ugust 2d.-The first mail coach in history started from London to Bristol, in England.

1784.-Charles Colling, of Ketton Hall, England, bought it cow at. Darlington market of Thomas Appleby for \$85, which he afterivards named Duchess-original stock cow of the famous shorthorn Duchesses.

1784. - First exportation of cotton, eight bags, weighing in all 1,200 pounds,

1785.--Power loom added to inventions for manufacturing cotton goods by Dr. Cartwright, of Fingland, greatly increasing the cemand for raw cotton.

1785.-First organization of American agrieuitural societies at Philadelphia, then the National Capital. George Washington, Benjamin Franklin and Timothy Pickering, orominent members.

1785.-Robert Ransome, of Ipswich, England, introduced plows with cast-iron shares.

1786. - Before this year cotton was a domestic manufacture amongst Southern ilanters. A letter from Thomas Jefferson suid: "The four southernmost states make great real of cotton. Their poor are almost entireiy clothed with it in winter and summer.

1786.--Franz Karl Achard, German chemist, discovered the true method of separating the sugar from the sugar-beet plant 

1786. - - Island cotton introduced in

1786.-Mrs. Colling, wife of Mr. Charles Colling, of Shorthorn breeding fame, first knotvn and recosnized as cattle breeder or in modern terms, a Cattle Queen.

1;86.-The French government purchased 300 shew from spain, the foundation of the French (Ramboullet) Merino.

1787.-The King of Spain presented a jack and jennet to General George Wasinington. The jack was caller the Royil Gift.

178\%.- 1 mill for the manufacture of cotton erected at Beverly, Mass.

$178 \%$ - 1 mill for the manufacture of cotton was erected on James Isliund. South Carolina

1788. In this year a Mr. Bisset, of Georgia contrived a cotton-gin having two rollers revolving in opposite directions by which five pounds of cleaned cotton wero unade per day.

1788.-President Stiles, of Yale, wore at ine commencement exercises, this year, a ill sown from material made and woven in Connecticut.

1788. - As early as this date the American seariet rose-mallow, said by Meehan to be "the most gorgeous of all the plants indigunous to the United states." was mentioned in WValter's "Flora Caroliniana."

178x. - First exten"sive production of Sea Island cotton. T'homas Proctor raised 5, (100) jounds upon a plantation near Savannah,Ga.

1788.--Swedish turnip and potato' oat adfled to farm croos in Ensland and Scotiatut.

1788.-King George, III., introduced Merino sheep in Fnciand. They did not thrive in that country.

1789.-First authentic notice of Jersey cuttle by the Iegislature of the Jerse Island passing an act to keep out fraudulent cows from France.

1789.-George Washington, President of the United States, and served eight years, to 1797 .

1789.-Jussieu founds the Natural System of Plants.

1789- Eclinse, the peerless thoroughbred died at the age of 25 . He was sire of 334 winners at the race course. Owned by Mr. 0. Kelly.

1789.-General Lafayette presented a fine Maltese jack to General Washington, named the Knight of Malta.

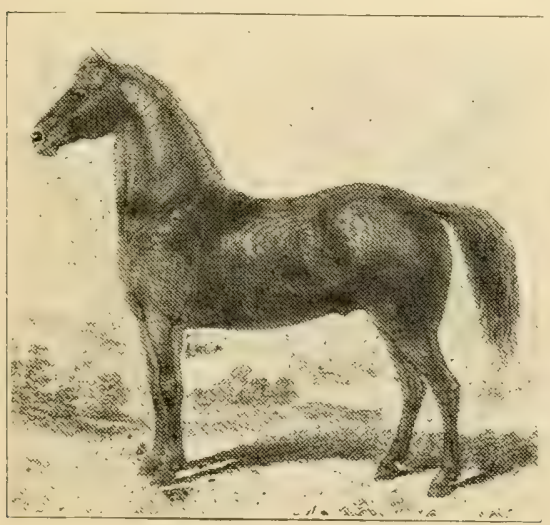

The foundation sire of the Morgan breed.

1789. - Justin Morgan, famous horse, parent. sire of Morgan horses, foaled this year at Springfleld, Mass.; died in 18:1: II as moved to Randolph, Vt. Justin Morgan was descended from the English thoroughWas descended from the English thorough-
bred, also from Arabians and Turks. Nin Morgan horse can be resistered without one sixty-fourth of his blood in the male line.
1789-Commodore Gardner sent orchiul blants of Enididendrum frasrant from the woods ot Jamaica One flowered two years ifter and was the first orchid figured in the Botanical Misazine.

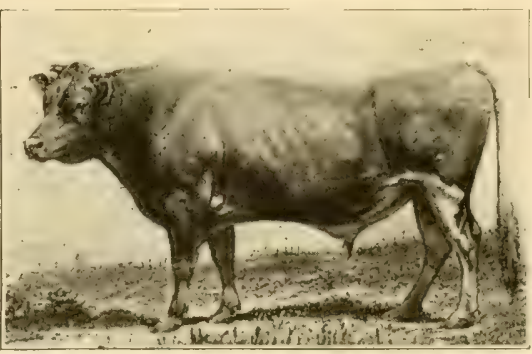

TORMENTOR-A typical Jersey bull

1789,- - On the Island of Jersey an act of the local Legislature probibited the impor ation of any foreign breed of cattle.

1790.-A cotton mill, driven by water, with ginning, carding and other machines, also spinning machines with eighty-four spindles each, put in operation at Statesurg, S.

1796.-Great injorovement in the trealli: cotton gin made by Joseph Eve, of Providence, 12. I., then residing in the Bahama. 1790.-Almy \& Brown established cotton mill at Pawturket. F. I. In the same year a mill was erected in South Carolina. 1790.-.-Successfu: attempt to grow Seg Island cotton in the United States by Mr. Wm. Elliott, near Beaufort, $S$. C. Seed procured from the Eahama Islands.

1790.-Small's swing plow and Meikle's threshing mathine brought into general use.

1790.-When Alexander Hamilton was Secretary of State under George Washing ton as President, the exports of tobaceo constituted 21.5 per cent, of all exports, and only second in importance to flour.

1790.-Gnethe writes on the metamorphosis of plants.

1790.-Thomas Booth, founder of a Shorthorn cattle family, commenced breeding at Rillerby, in lorkshire.

1790.-The New Ingland Farmer, volume of over 300 pages, published Worester, Mass

1790. - The first Prussian veterinary college establislied in Berlin

1\%90.-The Hugarian government estalulished a sturl of Arab horses at Babolna, under the lepartment of Agriculture, for the purpose of raising army horses.

1791. - In this year Mr. Heaton, a butcher, who had settled in New York about 1775 . imported some Shorthorn cattle from the herd of Mr. Feorace Culley. of Northumberland. What becane of them is unknown.

1791. February 26th.-New York Society For the Promotion of Agriculture, Arts and Manufactures organized on this date.

1791.- Asrieultural sciciets formed at Kennebec, Mass. (now Kennebec, Me.).

1791. - According to Dr. Elwood Harvey, in an essay on the American trotting horse trotting as $a$ spor began in Fingland in this vear. He mentions an account of a brown teen miles in the Essex Road in fifty-eight minutes.

1791.-Otter sheep, with a long body and short, crooked legs, originated from a malformed twin ram. Ffforts were made to jireserve this sporadic variety on account of its inalility to run and jump and thus cscape from an enclosure. In the Jastern States it promised to become a. distinct species, but it has lisappeared. Imagining that the ewe had been frightened by an witer (then orcasionally seen in the vicinity) leople called it the otter shory. This state. ment is from Harper's Book of Facts." 
1791. - The first English veterinary college established in London.

1791. - Four S'banish Merino rams received into the United States, one ram supposed to have been used in the vicinity of Delaware until $180 \mathrm{~s}$

1792, March 7th.-Western Society of Middlesex IIusbandmen formed in Massachusetts.

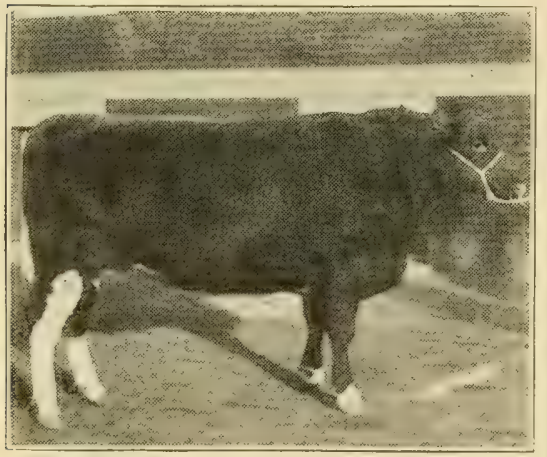

BUTTONWOOD DICK, 7th-CHAMPION RED POLLED STEER, CHICAGO LIVE STOCK EXPOSITION OF 1911. Exhibited by the Iowa State College, Ames, Iowa.

1792.-Pierre Legaux, a Frenchman, torether with a number of Philadelphia people, set ont a vineyaral at Springmill, on the Schuylkill river.

179:, April 11th.-The New York Legislature appropriated a sum for the Columbia College to endow an agricultural professorship.

1792,-As an experiment Mr. Charles Colling, Shorthorn eattle breeler, used a bull which was half shorthorn and half Galloway. This was called the "alloy" strain and was afterwards bred out.

1792.-Arthur Yourg, of West Suffolk, in England, mentions "universally Polled cuttle, red, inrindle or yellowish-cream color, famous for their quantity of milk:" the orjginal Red Polled rattle.

1792...British TVool Society of England mentions sheer of Morfe common near Bridgnorth, spotted-faced Polled breed, origin of Shropshives.

1793.-Vineyards planted in Jessamine county, Kentucky, by a colony of Swiss grape growers.

1793.--The Macartney rose brought to Fngland from China by Iord Macartney.

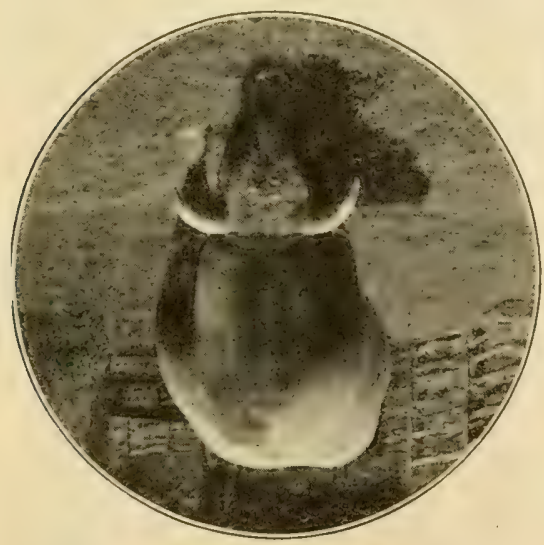

YOUNG AIICE'S PRINCE. $A$ St. Louis World's Fair champion Shorthorn bull.
1793. "Favorite," Shorthorn bull calved this year, was an inbred bull and was used co inbreed to an extraordinary extent. His son by his own dam, the bull "Comet," was the first of the Shorthorn breed to sell at $\$ 5,000$.

1793, Fetruary 27 th.-By act of Congress, hreeding and useful animals were admitted into this country free of import duty.

1793.-- Jil Whitney's cotton gin invented, Ereatest stimulus to cotton production ir this country.

$179 \%$ - It appears that the invention of the cotton gin not only stimulater cotton production, but it also made cotton a com. petitor to flax, checking the production of bax for fiber and indirectly causing more attention to be paid to flax seed as a commercial product.

1793. - National Roard of Agrimulture of Great Britain organized, Sir John Sinclarr incipal advocate.

1703.-Hon. Wm. Foster of Boston imjorted two Mcrino eves and one ram from cadiz. He presented them to a friend, who cilled and ate them.

1793.-Sout - African white-haired eves crossed wich imported Spanish Merino rams, same being from the royal flock of King Gcorge, 117., of Fingland.

1793. - The latest form of foot or trealle gin for cotton was introduced in Georgia from the Iatiamas.

1791. - Accorling to the 1960 United States Census, a French traveler named Volney went to see all the American vineyards bo could hfar of in this year. even so far as IKaskaskia, on the Mississippi river, whero he was informed that the Tesuits har planted a vineyard, but that the French cuvernnient had ordered or influenced its destruction to prevent French grapes growing in Americá.

1794.--Society for lromoting Agriculture in the state of Connecticut organized.

1794. - Arthur Young published a book entilled "A Survey of Suffolk," in England, atnd mentions the hornless cattle of that country, sayins: "There is hardly a dairy of any consideration in this district whici ices not contain. cows which give in the height of the season eight sallons of milk a day and six are common among many for a large part of the season. For two or three months a whole dairy will give fivo allons "day on the average."

1791.- In this year, a writer named Rawin, in speaking of the cattle of Ayrshire, said: "They have another breed, called the Dunlop, which are allowed to be the best pace for giving milk of any cows in Great Britain or Ireland, not only for large quancity, but for richness and quality." The Dunlops are a family of the Ayrshire breal of cattle.

1794.--Matthew Patten removed from Hardy county, Virginia, to Kentucky, and carried with him some Fnglish eattle which he had bought of a Mr. Goff, of Maryland.

1794. - The Shaker Community at Mount Lebanon, N. Y., l,egan growing farm seeds and developed a large trade in them.

1795.- One of the earliest seed farms was established at Fnfield, N. H., in this year.

1795.- Sieur Etienne De Bore, of Louisiana, announced that he had discovered a process necessary to obtain crained sugar. He demonstrated it on his plantation.

1795.-In this year Nicholas Appert, a Frenchman, discovered the art of hermetical sealing of food, now well known under the title of canning. Fourteen years later he was avarded $a$ prize by the government. which had been offered, long before, for a method that would preserve alimentary substances without robling them of their satural qualities and juices.

1796.-Charies Colling, breeder of Shorthorn cattle, exhibited a steer in England and Scotland known as the "Durham ox;" weighed 3,024 pounds at six years old.

1796. December $7 \mathrm{th}$.- In his message to. Clongress President Washington recommended pecuniary encouragement for the establishment of institutions to promote agricultural interests. 
1796. - In Jancaster county, Pennsylvania. an outbreak of eattle fever was caused by South Carolina cattle being brought in and sold there. First report of splenic cattle fever, afterwards attributed to the ticks in southern cattle.

1796,-Mr. Johr Ellman, of Glynde, Sussex, Fngland, called a meeting at the town of Lewes to collect money for prizes to be awarded successful breerlers, which action ural Society.

1796.-Owing to the deficient harvest and foreign wars, English wheat rose from ordinary price of fifty shilling per quarter to ninety-six shillings per quarter.

1796.-In this year, according to tho American Shepherd by I. A. Morrell, an thibit of wool was made at Rambouillet in France, in order to boom the Rambouillet breed of sheep, of which the French government had a monopoly. A large number of the exhibit and unanimously arreed that the wool on exhibit there was the finest, longest, softest and strongest they had ever seen. wut they promptly got together and formed a combination to keep down the price.

1797.-John Arlams, Iresident of the United States, and served four years.

179\%.-Trustees of Massachusetts Agricultural Society commenced issuing tracts or bulletins.

1797. - Leiters patent, signed by Joln Adams, President, were issued in June of this year to Charles the first cast-iron Jersey, who inverted the frst cast-iron the farmers had an idea that the cast-iron plow poisoned the lind and promoted the rrowth of rocks!

1797. - In this year, from the flock of Colonel Gordon twenty-nine Spanish Merimo sheep were taken from Cape Colony, South Africa, to establish the fine wool flocks of New South Wales, Australia.

1798. - Robert Colling breeder and improver of Shorthorn cattle, exhibited a beautiful pure-bred heifer, known as "the whits heifer that traveled." Estimated live welght, 2,390 pounds.

1798. - In this year Thomas Jefferson wrote an essay in which he discussed the best form and curvature of tha mold hogral of plows, this being as far as known the first attempt in this country to apply scientific principles to such a prohlem.

1798. - The tomato first brought to Phlladelphia from Santo Domingo, but not regarded as a marketable product.

1798. - The shaker Community at Waterviet, N. $Y$., made brooms of broom corn.

17!8. - In this year, in Kentucky, was begun the Dufours vimerard. Where the first Ereat American grape, the Cape-an offshoot of the fox-grape-ivas propagated. This grape was popular in the early half of the nineteenth century.

1798.-Smithfield (I,ondon) Club organized. Duke of Bedford. President: Arthur Young, Secretary. Object, to promote improvement in cattle. Annual Cattle show instituted: first exhibition the following year.

1798. - The MeIntosh apole, a winter variety of Northern origin, discovered ظy John MeIntosh, of Dundela, Ontario, Canada.

1799. July 4th. - The flrst patent for a reaping machine in England was granted to Joseph Boyce, of Pine Apple Place, at Mary-le-bone, a northwestern suburb or London.

1799.-On the 13 th day of October a trotting match was decided on Sunbury common, Fingland, between Mr. Dixon's brown gelding and Mr. Bishop's grey gelding, each carrying $16 \mathrm{~S}$ pounds. The race was won in 27 minutes 10 seconds. The distance is not stated, but the time shows that it was a trial of endurance as well as speed. This item is from the book by Dr. Elwood Harvey.

1799.-First Tunis sheep imported into this country from Africa by Gen. Wm. Eaton, United States Consul. He sent ten head on the ship Sophia, bound for the United States. One ram and one ewe only survived the voyage. This pair was bred under care of Judge Richard Peters, of
Belmont, near Philadelphia, until he had i tine llock. The imported pair vere finally killed by does, the ewe raising her last lamt at the age of sixteen years.

1799.-Old Dionede, a thoroughbred the first Derby winner in Enclaud, imported into Virginia it the inge of twenty years. F'ather the American sallile horse.

1799.-Mr. John Westcar, of Creslow, Buckg, Englatod, commenced attending and exhibing at Iforeforl latirs. He won tiventy-one first prizes in succession at thr smithield Cattle show

1799.-In this year I,ouis Lesson established it tradiug post at Montrose, in Lee rounty, Iowa, and planted near his cabin a small orchari of about 100 trees that he brought from st. Charles, Missouri. This is the first quthentic record of fruit culture in

1799.-One of the earliest works on horticultural subjects published in North America was an American edition of "Marshall's Introduction to the Knowledge and Practice of Gardening," issued in Boston in this year.

1800.-Peter J, Curtenins, a large iron founder of New York City, advertised castron plews.

1800.- John Patten removerl from Kentucky to Chillicnthe, Ohio, taking with him some cattle o!: the English breed which his father had moved from Virginia to Kencky.

1800. The Northern Swy, a famous apple, was originated in New York state about this year.

1800.-In this year Leicester sheep were imported into Canada by Rev. Mr. Toofy, of Quebec.

1800.--In this year Mr. Ben Daris began the cultivation of the orchard in which was )riginated the aprle bearing his name. He was born in Prince Edwards county, VirButler county, Kentucky, where he acquired a large tract of land, and up to the outireak of the Civil IV ar owned about twenty siaves. He was the pioneer apple grower and nurseryman of that section of country, und his long experience in propagating finally produced the Ben Davis apple.

1800.--Bernard MeMahon, gardener, seedsman and author, opened a seed store in Philadelphía.

1800.-Thomas Bates of Kirlevington, appears as breeder of Shorthorn cattle. This herd was hred and held together fifty years. 1800. - The rigate Constitution brought a Maltese iack 10 the United States from her first cruise in the Mediterranean.

1800.-Faxmars' Magazine established. Faited by Robert Frown, of Markle; continued until 1827. Great help to British agriculture

1800.-Fichard England, of Bingham, and Jonas Reeve, of Wighton, Norfolk, England, (commente.

1800.-In England, Robert Meurs, of Somersetshire, was granted a patent for a reapins machine propelled on wheels but workerl by hand.

\section{THE NINETEENTI CENTURY}

1801.- Thomas Jefferson, President of the United States, and served eight years, to 1809 .

1801.- - Edwin Hammond born; died 1870; great improver of Atwood Merino sheep.

1801, - A communication to the Massachusetts $A$ gricultural Society contained the germ of a movement in behaif of agriculture, resulting in the holding of Fairs. It was recommended that "small bounties be given for certain articles."

1801.- - In this year MT. Delessert, a French banker, owning a farm near Kingston. N. Y. made an attempt to import some sheep of the French Ramboullet Ierinos. Unfortuwately three out of four perished during the voyage, and the survivor, a ram. was placed on his farm. According to A. I. Morrell, author of the American Shepherd,
this was the first individual of the breed introduced into this country. 
1801. In Gotober of this year Mr. Seth Adams, of Massachusetts, imported a Merino v'rum and ewe from Irance. He received an award of $\$ 50$ from the Agricultural Society of Massachusets for the importation of a pair of sheep of superior breed.

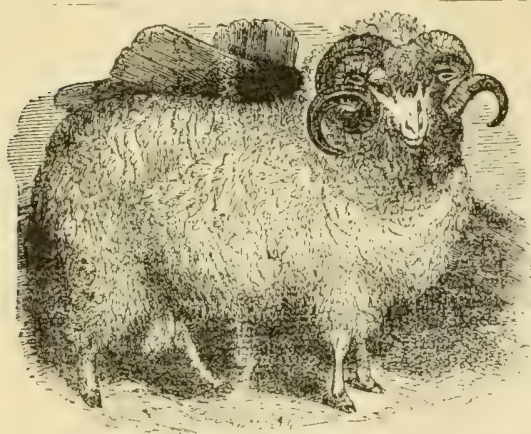

SPANISH MERING $\mathbf{H A M}$ - Picture repr. centing this breed when they were first im forted an hundred years ago. The improve ment by the American breeder represe

1801. - Straw 1 chaft-cuttins machine in vented by Lesier.

1801. - It was about this time that an eccentric man, known as "Johniny Appleseed," began planting apple seed througrous indiana and adjacent territory. His methou was to scatter them broadcast, and he lived io see 100.000 acres in orchards of his 1. lanting.

1802.- John Biddis, of Pennsyivania, making potato stareh.

180\%.- Tomatnes intruduced at Salem, Mass, by Michelo Corne, an Italian litinter, but he had considerable dificulty in persuading people to eat them.

1802 - 1 Pennsylvanian named Murruy migrated to Buncombe county, North Carnlina, tfn miles southeast of Asheville, and in this year found the Catawba grawes growing wild This grape was brought into general notice by Major John Adlum, of Georze. w.1, D. C.

180?.-Mr. Livingson, of New York state, Minister to France imported txo pairs ot Ifrino sheet).

180:-Col. Davict Humphreys, United States Minister to the Court of Spain, beins succeeded by Hon. Chas. Pinckney, was tenuered by the King of Spain a customaly present to retiring Minister of ten bars of wold weighing one pound each, but as the law forbids a United States Minister re ceiving nresents from a foreign court, Colon? liu:nphreys declined it, but requested the privilege of buving and taking 200 Merinn -heep out of the country The Spanish Court fid not formally grant permission, but alinwed the exportation to be made. Tlis heep were pure Transhumantes or herder sheep, and represent the Spanish Merin. heep in America.

1803.-Teri Thurston employed the first litt hammer at orange, Mass. for the purpose of making seythes.

1803.- A Shorthorn cow returned to Eing land from America: the owner also returning to his native country

1803. - Ameriran cranberry first grown at Cape Cod. Mass.

1803, Apri] 30th.-Louisiana Territory purchased from the French.

1803. May 1st.-The first American patent for a machine for cutting grain was issued to Richard French and J. T. Hawkins, of New Jersey. This machine was propelled on three wheels, one of which extended into the grain.

1803, November 19th.-Jedediah Turner, of Cazenovia, N. Y., took out a patent on it ihreshing machine to be operated by horse, ox or wind power, and warranted to thresh 150 hushels of wheat per day.
1803. - Steam engine first used as thrashpower by Mr. Aitchison, of Drumore, England.

1801.-Banauas were first imported into the United States in 1\&)4 by Captain John N. Chetser, ol the schooner Reynard, and nsisted of thirty bunches.

1801.-Dr. James Mease, in Willich's Domestick Encyclopedia, describes the Wineatp apple as follows: "Winesap-An autumn ruit of deep red colour, and sweet, sprightly aste: makes excellent cvder. * + * cultivated by Samuel Coles, of Moorestown, New Jersey.

1804.-Iorticultural Society of London founded by Sir Jos. Banks and associates.

1804.-Mr. John Price, of Kyail, Herefordhire, first bought Iereford cattle, breedin? chtinuousiy until 1841 .

1804. -Whe I'ennsylvaia Farmer," puhisher in ['hiladelphia, describes broom corn: -A useful plant, the cheapest and hest for making brooms, relvet whisks, etc,

1804 -Dr. 'Thurston. first United States onmissioner of l'atents, proposed that Fair he liela on market days at Washington, atter the Jinglish fashion. First Fair helu in Octolver of this year.

1804,-Humboldt wites on distribution of liants.

1805. Ice, uow so much used in keeping meats and fruit, hegan to be exported the pinneer being Frederick Tudor, of Boston. The first caryo of ice was sent to Martinique.

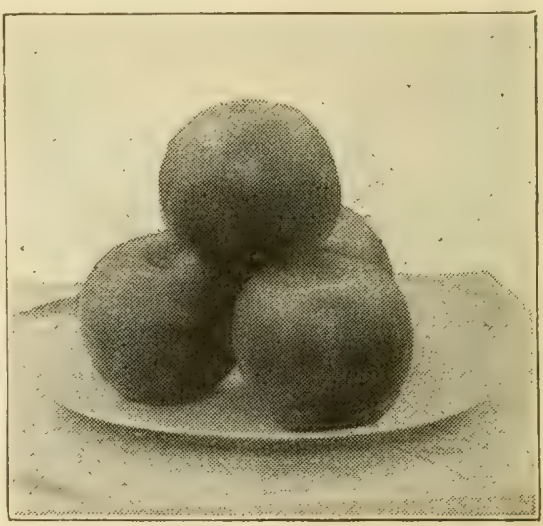

I tribute to Johnny Appleseed.

1805. - Ground bones began to be used in Fingiand as manure for turnips.

1805.-- In the fall of this year Grant Thormrn besan to sell seeds in New York and uilt up a substantial business.

1805.- In this year record was made of a erry pear tree in Holme Lacy, Hereford: hire, England. It covered more than hali in acres of ground, the branches bending town and laking root, and in turn producins rithers in the same way. From this tree fifteen hogsheads of perry was made in : single year.

1805.-Thomas J. Plunkett, of Kent England, received in patent for a reaper having the cutting apparatus suspended beneath and in front of the axle and the power behind.

1806.-Publication of Bernard McMahon's Imeriran Gardeners" Calendar, first wa corded history of American horticulture.

1806.--Wm. R. Dickerson, of Steubenville, Ohio, commencer sheep raising by a pur chase of Spanish Merinos from Mr. James aldwell, of Jennsylvania

1806.-.-Velocity, dam of Bellfounder trotted wil the Vorwich road, in England, sixteen miles in one hour, and thourh she broke lifteen times into a gallop and as often turned around, she won her match. Two years later she trotted twenty-eight miles i1 one hour and forty-seven minutes. 
1806.-In France, Napoleon restored goveroment stud establishments destroyed by lie revolution.

1806. What is eenerally accepted as being the first authentic fast record of mericin troters is spokem of. This was $2: 59$ for a mile trotting, made by the horse "Yankee" (breeding unknown) at Farlem, New York.

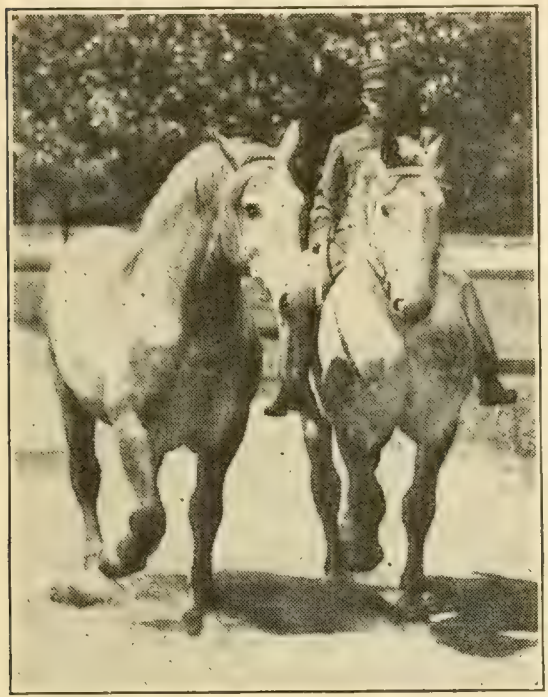

PAIR PERCHERON MARES-Sold to John H. Wray, of Fort Worth, Texas, for $\$ 2,400$ by $\mathbf{J}$. Crouch \& Son, after winning the highest prizes at the Dallas State Fair, 1911, and at the National Breeders' and Feeders Show of 1911 .

180\%.-In this year Lieutenant Zebulon $\mathbf{M}$. Pike, of the [nited States Army, who had ureviously explored the WVest and discovered Fike's Peak, was arrested in Spanish territory as a trespasser and escorted back by way of New and Old Mexico to the sea coast, thence to the United States. In pass11:g through the Mexican province of Turange he found a stock ranch on which in 000 sheep, cattle and horses vere owned by nne ranchman.

1807.--In this year Mr. George Culley, of England, published a book entitled "Observations on Jive Stock," in which it was ations on aive stock. in were kept by the Nobility for the rich milk which they gave io support the luxury of the tea table.

$180 \%$-The double white Bamksan rose introduced into England from China, and riamed in honor of Lady Banks.

1807. - The Beurre Bose pear raised by Dr. Yon Mlons and named Calebosse Bose in honor of a distinguished Belgium cultirator.

1807--Count Fumford observed that plants deprived of carbonic acid die, and about this sime Ingenhousz, another investigator, proved that they absorbed carbonic acid under the intluence of sunlicht. This led to the general basis of agricultural chemistry, that plants live mainly on inorganic mater.

1807.-Marty's edition of Miller's "Garleners" Dictionary," published this year, enumerated 124 orchids. The orchids now number about 10,000 species.

$180 \%$ - In this year it was reported that il Bates Shorthorn cow (Duchess) gave fourteen qualts of milk twice a day on grass alone, making forty-two ounces (two jounds ten ounces) of butter per day.

1807.-Eleazer Carver, of Bridgewater. Mass, eommenced the manufacture of roller yins and saw mills in Mississippi and Louisiana.
1807.- M : Basse Muller imported six Texino sheen at Philadelphia from the flock of the Prince of Hesse-Cassel.

180\%.-Elkanah Watson, of Massachusets, beginning with an exhibition of two Merino she(e) on the lublfe square at pittsfield, Mass, soon leveloped an interest in llvo

1807.-John Macarthur, of New South Wites, Australia, sent home to England simples of his clip, representing the beginning of the Iustrulian wool shipments.

1808.- - It the show of the East Norfolk Igricultural Society. Mr, Jonas Beeve, of wighton, exhibited a Polled bull combinin the merits of the Norfolk and suffolk rartement of Rea folled eattle.

1808, July 11th.-Siamuel Griflith, of st. Louis, who appears to have been a trader in 'ive stock arberriser for good beef cattl vitahle for the New Orleans market.

1808.-Commencement of public sfreen shearines by Georse Custis, at Arlington. Va, near Washington,

1808. First jack stoek imported into the New England States from Cape de Verdo sland:

1808.-Hugh WVatson, of Forfarshire, Scotland commences hreeding Aberdeen-Angus caftle, he bejng nineteen years or age.

1808, December.-Four of the best flocks of Merino sheep in Spain being confiscated by the Junta, were sold at Badajos to buyers from the United States and England. This was after the second invasion of the French into Spain.

1808. In this year Hon. Wm. Jarvis importerl Merino sheep from Spain. They were Paulars, Aiguerras, Negrettis, Escurials and Montarcos He bred them separately until isto, when he mixed them all together fol the reason that they were very much alike, ind he knew of no good reason why they hould not be bred together.

1808. The Thereford bull Wellington calved this year; bred by Benjamin Tomplins, Jr: one of the famous sires of this breed: sold for $\$ 1,400$.

1808-Mr. Seth Adams moved his Merino sheep from Massachusetts to Muskingum county, Ohio.

1808. - In this year Albert Gallatin mentions a cotton mill as being operated by water power at Petersburg, Va.

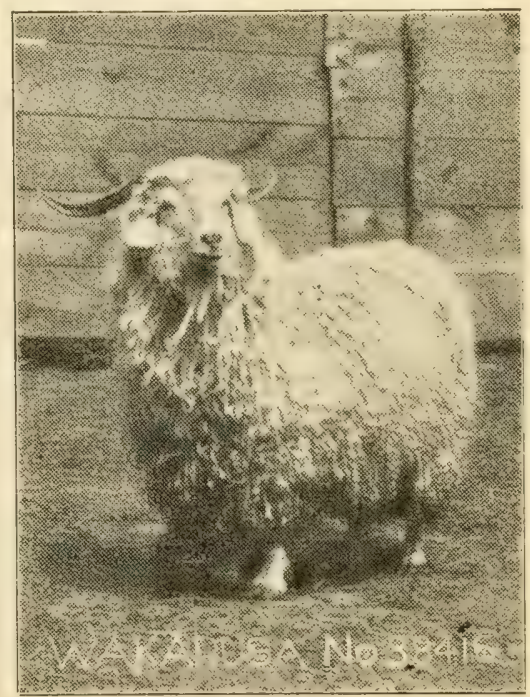

CHAMPION ANGORA GOAT owned by R. C. Johnston, Lawrence, Kas. 
1809.-In July of this year Col. Richard Feters proposed that the Philadelphia Society for the Promotion of Agriculture plements i manufictory of agricultural imfor receiving and vending them. He stater that no manufactory of agricuitural implements in general existed in the United States, although the demand was prodigiously great.

1809.--James Madison, President of the United states, and served eight years.

1809.-Mr. Thomas Rotch migrated from Connecticul to Stark county, Ohio, with a 1ew Merino sheep.

1809. - Twelve sheep of the Spanish Mrerino Escurial llock imported by Mr. Jarvis for a total of $\$ 15,000$

1809. - The Columbian Arricuitural Society instituted: first organization to hold important Fairs.

1309.-Mr. Wns. Jarvis, of Vermont, Minister to Portuga!, sent home 200 Spanish Merino sheep.

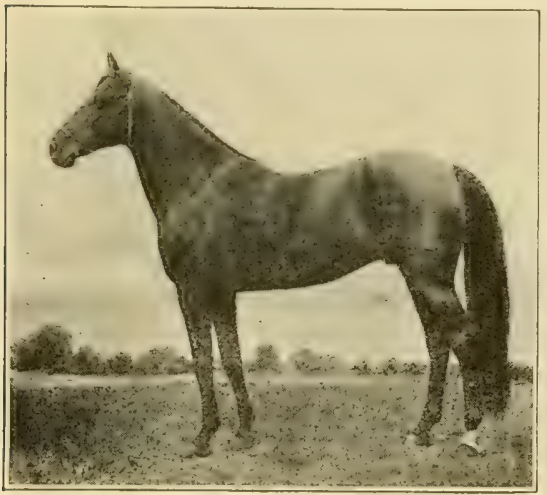

WILLIAM PENN, 2:071/4 - A COLT TROTTER. A free-for-all trotter and sire of trotters Sire of Miss Penn, 2:16: A. Penn, 2:173/4; Steel Pen, 2:181/; Voca, 2:191/4: Silver Pen, 2:151/4; and others. Owned by N. Wr. Bowen, of Delphi. Ind From photo by Schreiber, of Philadelphia

1810. August 25th.-At Philadelphia, "Boston Florse," a chestnut gelding, fourteen vears old, trocted one mile in $2: 4 \mathrm{~S} \frac{1 / 2}{\text {, in a }}$ sulky, for $\$ 600$. This record is vouched for l,y J. $H$. Wallace, trotting authority, and now generally accepted as the first reduction of an established time record by an American trotter.

1810.-A well-known firm, Reitz, Van Breria \& Joubert, agriculturists and extended land proprietors in the districts of Bredasiorp and Swellendam, South Africa, made first successful importation to that country of Spanish Merino sheep, there being two bucks and twenty-five ewes in the importation. During the Napoleonic wars in wirope the wool of these sheep sold for 90 cents per pound.

1810. - The making of cheese as a business began in Herkeimer county, New York.

1810. - First American cigars made in the United States by Mrs, Prout, wife of a farmer of South Windsor, in the Connecticut alley.

1810.--Partial sale of Shorthorn cattle by Robert Colling. Sixty-one cattle averaged 617.94 per head.

1810.-Mr. Seth Adams, of Zanesville Ohio, sold a pair of Merino sheep to Judge Todd, of Kentucky, for $\$ 1,500$.

1810.-Hon. Henry Clay, of Kentucky, introduced fine jacks into that state from Spain.

1810. - Searcely more than one variety of the Moss rose was known at this time, though now there are more than an hundres?
1810. - The tea plant introduced into Brazil it Rio de Janeiro.

1810.--By this time the invention of Nicholas ippert was userl in Fngland for canning fruits and regetables. In this year an English patent was granted to one Peter Durand for a can made of tin to ne used in bermetically sealing food, the patent also covering the use of glass, pottery and other fit material.

1810.-Captain Wm. Smith bought a shorthorn bull and took it to Fayette eunty, Kentucky.

1810. - Sale of Shorthorn cattle by Charles Colling at Ketton, Wngland; average for forty-seven head, \$757: top price for the luull Comet, $\$ 5,000$. This was the dispersion of one of the greatest herds of cattle in Shorthorn history. The brothers Charles and Robert Colling had separate herds, and this was the first to be dispersed. The Collings were the first great improvers of modern Shorthorn cattle and they were first-class advertisers also by show-yard methods.

1810. - The cranbery first cultivated from wild bog iruit in the vicinity of Cape Cod, Massachusetts.

1810.-- In this year Albert Gallatin said of American household manufactures: "By far the greater part of the cotton, flax and woolen soods was manufactured in private families, mostly for their own use and vartiy for sale.

1810.--Sorghum recommended as a soiling (rop under the name of Guinea corn by lohn Lorain, in memoirs of Philadelphia Agricultural society.

1810. - In this year $2 S 3$ linseed-oil mills were enumerated in the United States,. of which 171 were in the state of Pennsylania.

1811. - The Merino Society organized in Fingland with Sir John Banks as President and fifty-four Vice-Presidents.

1811.- In this year Lord Braybooke, of Audley Ind, Fingland, established a herd of Alderney cattle with one bull and edght cows which cost $\$ 94.70$ per head delivered this estate.

1811.-Spanish Merino sheep introduced into Silesia by Ferdinand Fischer, of Wirchenblatt. They were Nigrett $\theta$ and Infantado Merinos.

1811. - Mr. Alraham Heaton imported panish Merino sheep, forty-two head.

1812,-Shorthorn cattle of Virginia importations taken to Ohio.

1812. - This is rear in which the state of Louisiana was admitted into the Union.

1812. - Artificial heat first employed in curing toliacen to protuce the piebald or swangled tobreen of Virginia to satisfy the oreign demand.

1812.-A Mr. Cox, of England, arrived with a few Shorthorns, taking them into ew York state.

1812. - A party of twelve men of St.Louis, under the leadership of Captain McKnight, established what was afterwards called the Santa Fe trail, marvels of the New West.M. B. Thayer.

1812.- English wheat advanced to 126 shiilings and 6 pence per quarter. Highest in history.

1812.--Importations of Leicester sheep by Christopher Dunn, of Albany, N. Y.

1812.- At this time the factory of $\mathrm{S}$, \& A. Waters, of Amsterdam, N. Y. Was turning out 6,000 sexthes annually.

1813. - Fnster \& Murray, of Pitsburgh, Pa., carried on the manufacture of seythes, sickles, hoes and shovels by steam power.

1813. - E'stalishment of the famous flock of Stephen Atwood, who was the breeder of Merino sheep for fifty-four years. He started with one ewe bred to a neighbor's buck: result, twins-a buck and ewe lamb.

1813. - The thoroughbred horse imported into Cape Colony, South Africa, by Lord Charles Somerset, who was then Governor of the province.

1813 -Duncan, in his "Farming of Herefordshire" said of the Hereford cattle: Large size, an athletic form, an unusu:zl 
neatness, characterize the true sort; the prevalling colnr is a rerblish brown, with white face."

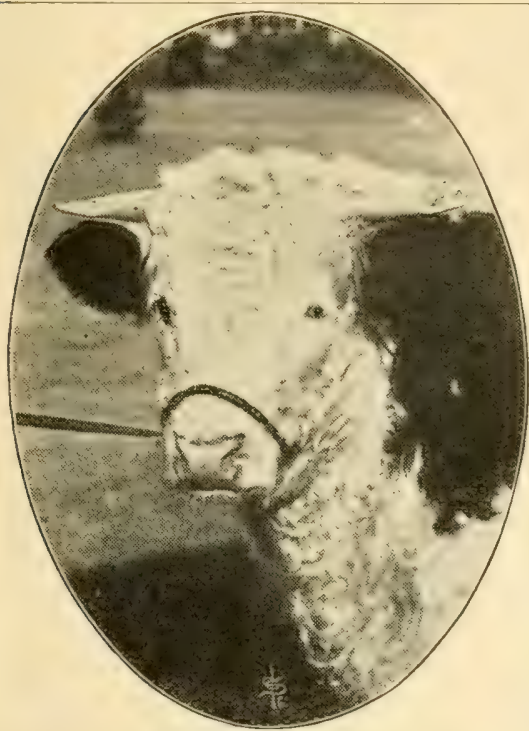

HEAD OF DEFENDER-International grand champion steer at Chicago. A pure-bred Hereford.

1814. - The seer of the Miner plum planted in Knox county, Tennessee, by William Dodd, an officer under Gen. Andrew Jackson. It went by different names for some time, and it is not became known as the Miner.

1814.-Accordins to DePronville, a French writer, in this year there were only 124 varieties of roses, but by the advantage of multiplication by seed there are now more multiplication by see
than 6,090 varieties.

1814. - Valuable purple and striped variety of sugar cant brought to Georgia from the Vest India isiand of St. Eustatius.

1814.--Fichard Booth (son of Thomas) commenced breeding shorthora cattle at Studiey, in Yorkshire

1814-Mr. Bezaleel IVells, of Fort Steuben. Ohio, bought large numbers of Merino sheey from Hen. WVm. Tarvis.

1814- - Texas or Southern eattle fexer, first mentioned Dr James Mease of Philadelphia, said that cattle from South Carolina so certainly diseased all others with which ihey mixed in their progress to the North that they were nrohibited by the people of Virsinia from passing through that state.

1814. - "Let us cultivate the ground, that the poor as well as the rich may he 'fillerl, and happiness and peace be established throughout our borders." - On title page of Third Volume Memoirs of the Philadelphia Society For Promoting Asricullure, puv. lished by Johnson \& Warner.

1814.-In July of this year Jethro Wood, of Scipio, N. Y., was granted a patent for a cast-iron blow, having the mould plate, share and landside cast as three parts. This i.ecarne the foundation of many improvements of later date.

1814.-Mr. Bezaleel TVells, Mr. Patterson Henry Baldwin and James Ross erected a woolen factory at Steubenville, Ohio.

1814, December 2Sth. Birth of sir Joln

Bennett Lawes, of Hertfordshire, England, student of agricultural chemistry, whose field and animal experiments are of great service and value throughout the world.

1814.-Nicholson, in the Farmers' Assistant, describes modern grasses and mentions that they seed freely.

1815. Corn (wheat) laws of England reenacted.
1815. - In this year Joseph Louden Macallam, a Scottish engrneer, became Surveyor General of Roads at Bristol, England, and put into practical use the theories he luad thouglit nut. This resulted in the invention and develorment of what is now called the maradam road.

1815.-General failures of American woolen manufacturers had disastrous results on the sheep-raising industry.

1815.--In this year I, Inis Downing. of Salem, Mass., moverl to Concord, and there began the manufacture of coaches and waturs.

1815.-Rohert Barclay, of Bury Hill, near Dorking, in England, received two plows, sent him liy Judge I'eters, President of the "ricultural society of America. When lested arainst the best English plows, they lid the work with two horses which lingiisl plows did with four

1815.-Wirst references to the compeas as od for foraze and soil renovation.

1815.--Ahout this time Ezra Doggett, an cnflishmail, frought the secret of eamning roods to inerica and engaged in packing if hermetically-sealed food and engaged in the business with his son-in-law. Thomas Kenset:

1816.-In this year died, on Boone's Creck, Washington county, Tennessee, a armer whes pros was Jacob Hoss, rreat-grand ather of Bishop s. H. Hoss, and came there from Pennsylanit in 177

1816.-In this year, at Montreal, Canada, French draft horse was imported that was owned by James McMatt, of Washington county. New York state, as late as 1833. He was called Furopean and supposed to be a Percheron.

1816. - The Oakes cow, famous in Massahusetts this year gave forty-four quarts inilk per lay; and made 467 pounds of inter in one year.

1816. - The Isabella grape, supposed to be native of Dorchester county, South Caroina, was taken north this year. It was introduced into New York by Mrs. Isabella Gibhs, of Brooklyn, and was named for her. it was the third great American grape, being a shoot of the wild fox-grape.

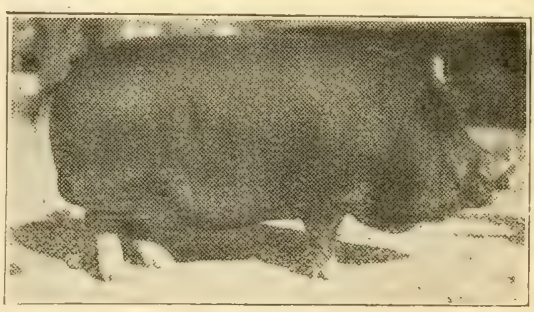

A TIPICAI, POIAND-CHINA BOAR.?OYAL DUDE, as a yearling, weighed 540 jounds. This is one of the champions at the freat St. Louis Fair. which at one time was the greatest Fair of all.

1816--The "Esig Chinas," large, white hof's, with sandy spots, taken to IVarren county, Ohio. Therkshires following in $1830^{\circ}$ Irish Grazjers in 1839 : and a breed called Byfields. All had something to do towards establishment of the breed of Poland-China sivine.

1816. - This is known as the year without a sumner. The corn crop failed for want of sunshine throughout the country. At Watertown, $N$. Y., on June 7 th, there was l'e three-eighths of an inch thick. In Maine, commencing on June 12 th, snow fell for three days, and the earth was frozen half an inch deep.

181\%.-James ALonroe, President of the Inited States, and served eight years.

181\%.-In Philadelphia appeared "The "iew of the Cultivation of Fruit Trees," hy Wm. Coke, credited as being the first American pomological book. 
181\%. - The Hessian fly, so called from the supposition that it was brought to this country in some straw by the Hessian soldiers during the Revolutionary War, scientifically described by the naturalist homas Say.

181\%. - The "Missourt Intelligencer and Boon's Lick Advertiser," the first newspaper publication in Missouri, printed at Old Franklin, in Howard county. It was neces sarily somewhat of a farmers' paper.

1817. - First pure-bred Devon cattle imported by Mr. Patterson, of Fialtimore, from the English herd of the Earl of l.eicester.

1817.-First nedigread Shorthorn bulls imported into the Enited States by Samuel M. Hopkins, of Moscow, N. Y.

181\%.-Fion. Henry Clay, of Kentucky, improrted Hereford cattle, four head.

181\%.-Colonel Lewis Sanders, of Kentucky, imported cight shorthorn cattle and four Longhorns.

1817.--Felix Fienick, of Kentucky, drove 100 prime fat shorthorn steers to Phila delphia, and sold them for $\$ 134$ per head on the beef market. Mr. Renick was tho lirst man to drive cattle over the Allegheny Mountains to the New York market.

1817.- In his book, "View of the Cultivation of Fruit Trees," nublished in Philadelphia by Mr. Coke, he illustrated and described the Winesap apple and characterized it as then "becoming the most favorable cider fruit in West Jersey." This book is considered as being the beginning of systematic pomology in America.

1817.-A few Longhorn cattle-from England imported into Kentucky, but soon crossed with other breeds and lost sight of

181\%.-The Noisette rose, raised by John Champrey, of Charleston, S. C.. from seed of the Musk rose, fertilized by a blush China rose. From the seed of this hybrid Thilippe Noisette; a Horist of Charleston, obtainer a rose which was afterwards disributed as Blush Noisette by his brother rouis, of Paris.

1818. - In this year Elisha Mills, from the New Engiand îtates, established himself is a pork parker in Cincinnati. This was the besinning of a Freat industry in Cincinnati, which gave that rity prominence for many years and became for a time the great fork packing center of the country

1818. - Crimson clover introduced into the United States by Bedingfield Hands, of Chestertown, Md.

1818. - Importation of Devon cattle from England by Uon. Rufus King, of New York

1818. - High water on the river Nile, $3 \frac{1}{2}$ feet ahove proper level, destroving crops. First record of great flood in modern agriculture.

1818. -Dearhorr's seeding pear raised this

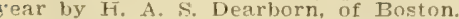

1818.-Robert IValker, of Kincardshire, Scotland, commencerl breeding Mberdeen-

1818-. New York Ilorticultural society cstahlisherl: first organization of its kin in the United States.

1818. - Mr. James Prentice of Lexington, $\mathrm{Ky}$., imported hulls of shorthorn blood.

1818. - Sale of shorthorn cattle by Mr. Robert Colling, of Brampton. Sixty-one head averaged \&644.35.

1818. - Steam engines on condensing principle erfeted wt Fast I, ithian, Scotland, to propel thrashing machinery. One of thes - doing sood work fifty-five years later.

1818, September $15 \mathrm{th}$.-Five great abatcolds in Paris, France, opened up, where al cattle, hogs and sheep for Parisians were slaughtered. These were the models of the world and had no rivals until in recent years American slaughter and packing houses have surpassed them.

1818. - Porter's Spirit of the Times of December 26th, 1856, says: "The first time ever a horse trotted in public for a stake was in 1818 , and that was a match against lime for $\$ 1,00 \%$. It was a bet that no horse could trot a mile in three minutes. It was accepted by Major Wm. Jones, of Long Island, and Colonel Bond, of Maryland. The horse namer at the post was Boston Blue, who won eleverly and-gained great renown. Boston Plue was taken to England, where he trotted eight miles in 28 minutes 55 seconds. He was a rat-tailed, iron-gray gelding. 16: hands high, and nothing is known of his pedigree.

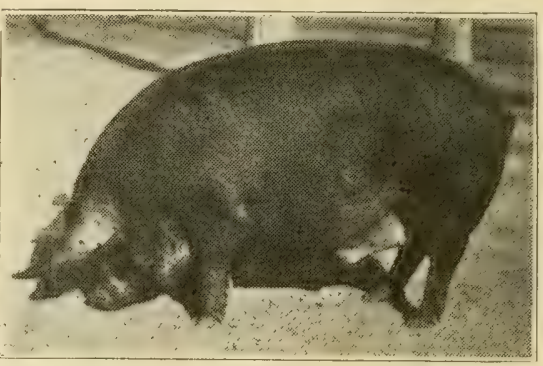

DUROC-JERSEY BARROW - GRAND CHAMPION AT NATIONAL WESTERN SHOW, DENVER, COLO., 1911. Exhibited by the Agricultural College, Fort Collins,

1818.-A sea captain, James Jeffrles, rought over a pair of white hogs showing r.juish spots on skin. since known as Bedford hogs, from English county in which they originatirl. He placed them on his farm at West Chester, Pa.

1819. - In this year Chevalier barley, best type for malting, was originated in Suffolk, England.

1819. -First American patent for 1mproveovement in farm hoes was registered by Buililey, of Colchester, Conn

1819---In April, John Stuart Skinner, of Marvland, estahlished The American Farmer it Baltimore. the first agrieultural journal in America. "homas Jefferson and Andrew Jackson were patrons.

1819. - The Bowbon rose was introduced nto France by Jacques, head gardener of the Duke of Orleans, at Neuilly, who received it in 1819 frnm T3reon. Director of the Royal Garrlens in the Isle of Bourbon.

1819. - Part of the Hereforl cattle herd of B. Tompkins, Jr., sold at auction after his death. Average for twenty-eight cattle, highest-priced cow, $\$ 1,365$

18:0.-Charles Mitchell, a London-born Linglishman arriving from scotland, entered the employment of $\mathrm{Wm}$. Underwood \& Comtrany, forried for the purpose of engaging in the business of canning food.

18:0. - In this year, Colebrook, in Litchfield cunty, Massachusetts, returned the largest manufacture of seythes of any town in the Inited States.

18:0.- Appearance of the midge in Vermont, the first insect known to ravage tho wheat erop.

18:0. - At this time the firm of $F$. F Farvell \& Co., of West Fitsburs, Mass., was making a good reputation as manufacturers of scythes, which industry was kept up many rears

1820.-In the Sydney, Australia, Gazette of this year it was reported that in England hadly-bred Australian wook sold at 40 to 44 cents a pound; light and fairly-bred at 42 to 46 cents: fine heavy wools at 48 cents: the best light wools at $\$ 6$ to 90 cents a pound.

1820.-.Richard W. Meade, Minister to spain, imported Merino sheep from spain ut Philadelphia; principal foundation stock if Delaine Merinos.

1820.-." "Young Clydesdale," stallion gained highest premiums at Scotch Agricultural shows. Sold at five years old for $\$ 600$ at zenith of popularity

1820.--Alfalfa clover was tried this yoar in New York state. 
1820.-Dr. Waring made a good edible vil from cotton secel at Columbia, S. C.

1820.- In this year the price of seythes langed from \$12 to \$1s per dozen.

1820.-Colonel James Ridley, of Davidson county. Tennossee, earliest pioneer juck hreeder of that state, hought the jack Compromise in Virrinia.

1820.-The vensus of this year enumerated a population of $9.637,999$, including $2,07 \%$, i. 16 persons engaged in agriculture.

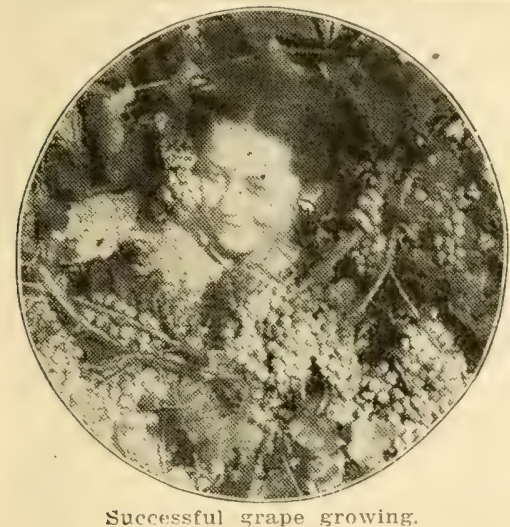

18:0. - The United States Department of Agriculture credits Mr. John Adlum with making the tirst really successfui effort at arape rrowing on the Atlantic Coast. In this year he planted a vineyard near Georgetown. D. C., consisting of native vines. His meneral cultivation was the beginning of a new era in grape history.

1820.-A stallion. "Young Rattler," noted for stlish, high-headed appearance and proud-stepping action. Incestor of Irench coach horses.

18:0.-Steam in closed circuits introduced in greenhouses, foliowed by luot-water lieating.

18:0.-Closing out of the shorthorn herd ci Mr. Rohert Colling, of Brampton.

1820.-The great Irabian stallion. Gallilolis," imported into F'rance. Great orifinal sire of the Iercheron hreed.

1820.-Lord Barrington, sreat early imrover of Berkshire swine, commenced selection and breeding.

18:1.- A. I, and F. A. Stevens, of IIohoken, N. J., obtained patents for improvements in cast-iron plows, designed to make them easier of draught.

1821. - In this yent William M. Muldrow, a famous adventurer. started a drove of milch cows from Jainjra, Mro., to I,ord route was a trackless territory infester isy Indians, but a remnant of the party with $a^{-f e w}$ cows finally arrived at their destina$a^{-}$fe
ilon.

18\%1.--Philin Jauncer, of England, father of Engish Jersey eattle breeders. tought a row which he called "l'ug." She gave is "jarts of milk per day, from which he made $121 \%$ pounds of butter a week.

18:1. - Lucerne or alfalfa elover mentioned hy a writer in south Carolina as a most valuable solling crop.

18:1. - In this year Thomas Massey, of Delaware, advocated soiling for the dairy, recommending corn as heing of grent value for the purpose.

1821. - Keene's Seedling, a variety of strawberry, raised by Keene, of Isleworth (near London), the celebrated English strawberry grower.

18:1. - In The American Farmer of this year Caleb Kirk rescribed a mill for cleaning clover seed.

1821. - First steam-driven mill for crushinc sumar cane erected in Louisiana.
1821. -Wm. Berry, of Washington county, Pennsylvania, purchased a ram and ewes from W. R. Dickinson's llock and established the black Top Spanish Merino sheep.

182:- In January of this year, in the sland of Tasmania, the first agrieultural society of the new Southern world was organized. Its professed objects were the protection of llocks and herds from the depredations of thieves and irresponsible depredations of thieves and irresponsthle
nomads, and for the encourafement of better moral hahits among the population.

189.3 - Aceording to Major Henry E. AIord, authority on diry cattle, the first Iyrohires in Imeviea is ere brought to New York in this year.

183:-The Taston (Mas3.) spade and Shovel Manufactory commenced by Oliver imes was making 2,500 dozen shovels annually.

$182 \%-T u l y$ - 11 th of this year records the mportation into 4 merica of the thorouglibed stallinn Bellfounder, bred in the district of Norfolk, Fingland, and bought by Tames Bbot, of Boston, and imported by Bellfounder was a bright, beautifil With black legs, fifteen hands high. He was said at the time to be the fastest and fist hred horse sent out of England. At five years old he trotted two miles in six minutes and later trotter nine miles in linty-r.u

18:2.-Thomas Green Fessenden founded the New England Farmer at Boston, Mass. and edited it until his death in 1837. This publication is now discontinued.

18\%.-Weter Henderson, market gardener. seed grower and horticultural author, born in this year near Erlinburgh, Scotland.

18:' - The seven sisters' Ionse introduced nto England from Japan by Thunberg.

1822.-In his American Orchardist, the fator. James Thatcher, gave valuable lirections for thw selection of seed in at tempting to produce improved fruits and regetables.

18:"3. July ith. - t Sydney, Australia was held the preliminary meeting organizing the lirst Australian Agricultural society. Presi. dent. Hon. Baron Field; Patron, Sir Thomas Brisbane: Vice-Presiclents, Rev. Samuel Marsden. Wn. Cox. Robert Townson and Iannibal Macarthur: Secretaries, Alexander Berry and George 'Jhomas Palmer.

18:2.-First Shorthorn Herd Jook pub. iished ir England. It was hrought out by Mr. George Coates in his old age and coninued toy his son.

18:2. - Nicholas Longworth, of Cincinnati. Chio, receired cuttings of the Catawba Hrape from Major Adlim and thereupon cstablished a vineyard. His grape growing and wine making were eminently successful or many years:

1822.-First Shorthorn IIerd Book published in Fngland.

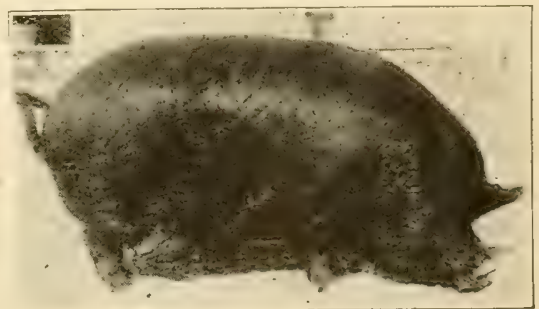

DUROC-JERSEY SOW - HATTIE SECK. as a yeariting, Weighing 500 pounds. Won sweepstakes at the St. Iouis Fair. Exhjbited by N. B. Cutler, of Carthage, Ill.

18:2.-Henry Kelsey, of Florida, Montgomery, count, New York, imported a pair of red hogs from England. These hogs were afterwards called Durocs, named for a famous horse he owned. 
1823. - At one of the quarterly meetings the Australian Agricultural Society paid for and destroyed 387 native dog tails, it being a fair presumption that previously the dogs had been destroyed.

1823, January 1st.-Sturients first received at Carliner Lyceum, an institution for instruction of mechanirs and fammers. Rev. Benjamin Hale, first Iresident. The institution was named in houor of Robert Hallowell Gardiner, who obtained the grant of 41,000 per year to put the first agricultura college on its feet. They had. wenty regubar students the first year, besides others who attended the short course in winter.

18:3.-At a dinner given by the Australian A gricultural Society the gardens of . Dr. Townson and Mr. Piper furnished eighteen kinds of fresh fruit and four kinds of dried fruit. The banana, the Orlean plum, the real peach, the cat-head apple and a fine kind of muskmelon were specially mentioned.

18:3, May 23d.--Historic sectional contest in liorse racing between the North and tha South. American Eclipse represented the North, and Henry, or, as he was originally nameri Sir Honry, remresented the South. Cclipse won two four-mile lieats out of three. Time, $7: 371 \%, 7: 49$ and $\delta: 24$. Average heats, $7: 57$, or $]$ minute 57 seconds to the mile.

18:3. - Grant Thorhurn's (New Jork) seel catalogue at this time was the only one issued in vamplilet form

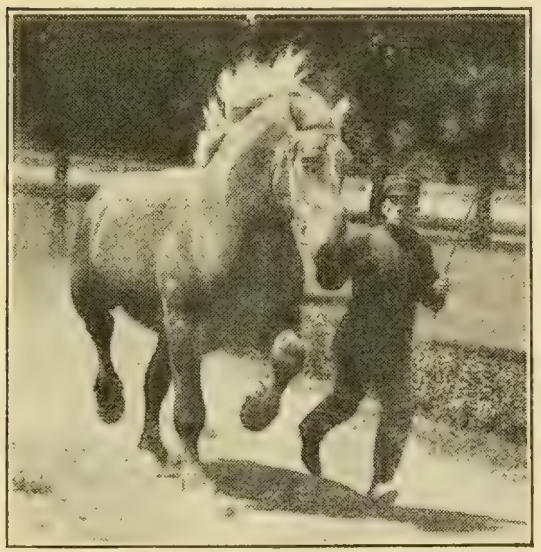

HULOT-PERCHFIRON STALLION. Champion any age or breed at the Fort Worth ited by J. Crouch \& Son, Lafayette, Ind.

1823.-Jean-Le-Blanc, a remarkable I'ercheron stallion, foaled in this year. To this sire a great portion of the finest, laryo J'ercheron horses trace their "rigin. He is considered as the great improving agent of his race. He died at thirty-two years of inge, the property of M. Miard, of Villiers. Department of Orne. He was a Percheron of the purest blood, strengthened by infusion of the Arah.

18:3.- Henry Eckford, famous as improver of plants, born in Scotland. "Our gardens 1) We much of their eweetness and beauty to him, anil his work has brought a blessing to many an humble flower lover who never heard his name."

18:3.-Abdallah, son of Mambrino, and sire of Hambletonian, a horte of very remarkable and positive character, was foaled in this vear on I.ong Island, New York, and bred by John Treadwell. Abdallah lived until 1854 .

18:3.-James NLDovell, improver of bickinson Merinos, comanenced heriling sheep in stark county, ohio, ending as breeder in 1587.

1823.-Hon. Chas, Rich, of Shoreham, Vt. establishea: a flock of Suanish Merino sheep.
1823.-Wherkshire swine introduced into the United States by John Brentnall, an inglish farmer living in New Jersey.

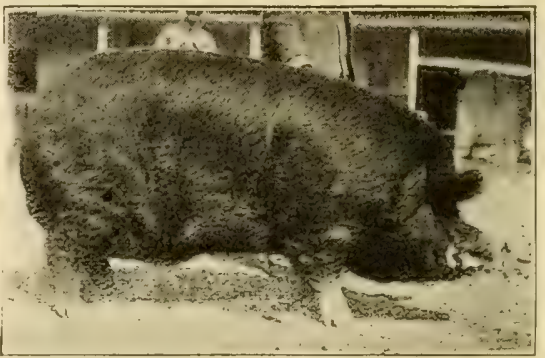

BERKSHIRE BOAR - CARLOS VICTOR. 2d. A three-year-old. weighing 700 pounds. Took first prize at several State Fairs and at St. Louis. Exhibited by Etzler \& Moses. f Convoy, Ohio.

18:1.--By act of Parliament, the English acre was required to contain 4,840 square ards.

1829.-Thomas Berwick, an English animal cy.tist, said of the zebra: "Such is the beauty of this creature that it seems by nature itted to satisfy the pride and formed for the service of man. and it is most probable hat time and assiduity alone are wanting bring it under subjection."

18:4. - The Merino buck Bolivar, owned hy $m$. $k$. Dickinson, of Steubenville, Ohio, on first premium in wool sheep classes at shington. D. C.

18:4. - The Acadians in Louisiana introuced a new method by which toluaceo was "lied under intense pressure in its own

$18^{*}$ T.-Mr. John J, Coiron introduced new sesil piants of sugar cane from Georgia, but riginally from the island of Eustatius.

18:5. - First tohaceo warehouse established $n$ Connecticut at Warehouse Point.

18:5,-Jolun Quincy Adams, President of the United Siates, and served four years.

18:25.-Floriculture, orignated in Philaidelphia, commenced to be of importance about this time.

18:5, Mirch 15th.-The following advertisement appeared in the Indianapolis Journal: "seed oats and potatoes. The subcriber has for sale at his residence on Circle street, Indianapolis, a quantity of seed oats, Jargely Early Blue, White Marino ind red potatoes." The advertisement was igned hy Isaac Coe.

18:5.-James Moores, of Steubenville, Ohio, nld the woot clis from one hundred sheep t $t$ one dollax per pound.

18:5. - Avrshire cattle mentioned by agriwiter Alton.

18:5. - At a meeting of the Australian Aricultural Society Mary Kelly received an award of twenty Spanish dollars for an exhibit of silk, and at the same meeting a threshing machine made by John Blaxland was exhibited.

1825.- In this year a large ox was mentioned in the newspapers: "A fat ox in tended for the New York market was reared at Shaftesbury. $V t$, and was exhibited at Troy, N. Y. March 38 . It was seven years old arid of the real American breed and said to weigh ",77? pounds."

182.5.-Colonel W. S. Hamilton, son of lexander Hamilton, made a contract to cupply beef to the garrison of Fort Howard at Chicago, Ill., and for this purpose bought and started a drove of cattle from springfield, Ili. This was the first shipment of Illinois cattle to Chicago. Previously the garrison had been supplied from Cleveland and Buffalo. The cattle referred to cost $\$ 10$ per head, and a young man named John I Iamlin accompanied them as drover.

1825.- In this year Iucien B. Maxwell, an American, who traveled to the Cimarron 
river, was married to a daughter of Charles Beaublen, a ploneer Frenchman, inheriting an immense tract of land since known as the "Maxwell Grant." In his later days Mr. Maxwell owned 10,000 horses, 10,00 cattle and 40,000 sheep. He employed 500 men, and was the first Amerioan ranchman of prom
west.

18:25.--The Daily Advertiser in Sentember of this year said: "The saxon sheep $1 \mathrm{~m}$ ported by G. \& $T$. Searle were sold at Brighton, near Boston. The highest price fiven fir a single one was $\$ 450$, and another was sold for $\$ 325$, and the average price, including !ambs, was $\$ 160$ per head. The purchasers were nearly all fentlemen exfrerienced in mising sheep.

18\%5, August 1st.-The following arlverifsement apleared in the Indianapolis cents is pound in specie for all the freslldug dinseng that is delivered to them. The dug (xinseng that is delivered to them. The from curls and cut roots."

1825. - In this year a party started from Franklin, Mo. to New Mrevico. They were eighty strong and had with them 200 horses and mules, They reached Santa Fe, 931 miles froh the place of starting. in due time. In record of this expedition it is said that after reahing New Mexico the first civilized habitation met with was owned by Juan Peno, who, in addition to owning cattle and horses, has flocks amounting to 150.000 sheep.

1825, Octnber. - f fat hog news item appearing this year gives come ldea of swine raising at the time. "A hog is feeding in Forks township. Northampton county, Pennsylvania that weichs more than 800 pounds. is eight feet nine inches long and seven feet in circumference. He is rapidy increasing in bulk and expected to weigh above 1,000 pounds at Christmas,"

18:6.- - In this year this horticultural item appeared and reac as follows: "It has been ascertained by experiment that linseed wil being washed over trees previously to their budding out will render them impervione to frost."

1826.-Rev. Patrick Bell, of Scotland, produced a mowing machine, having, in addition to previous inventions, a revolving apron or endless web for gathering. This is the oldest machine which came into general use. McCormick's cutting apparatus adopted in 1851 gave it renewed life.

1826. - In this year Hon. Wm, Jarvis, IVeathersfield. Vt., said that he began cross his imported flock of Spanish Merinos with Saxony sheep. At that time his average flece was three pounds fourteen ounces age fuece was three pounds fourteen ounces
to four pounds three ounces. His buck fleeces ranged from five and one-quarter to six and one-half pounds.

18:26--According to a letter written hy Hon. Wm. Jarvis, a great importer of sheep. foot rot was brought into this country with the sheep imported from Saxony in tinis year, He also said: "Foot rot was totally" unknown among Spanish Merinos:"

1826. - The Indiana Journal, published at Indianapolis, contained advertisement of Iohn Francis Dufour, Postmaster at Vevay, Indiana. He proposed to publish a weekly agricultural journal under the title of the Western Farmer. The announced subscription price was 32.00 a year.

1826.-A horse named Trouble trotted a mile in $2: 43$.

1826.--"Leaming," a deep yellow corn, originated with Mir. J. S. I Leaming, of Wilmingtor., Ohtis. This is the earliest of eight varieties of corn recognized by the Illinois Seed Corn Breeders' Association.

1826. - First mill established for the extraction of oil from cotton seed - at Columlus, S. C.

1826. - Finst offleial cotton quotation record. Middling upland cotton, New York market, highest price of the year, 14 cents; lowest, 9 cents per pound.

1826.-Maryland Agricultural Society offered a special premim to owner of lamb shearing the greatest quantity of picklock wool; won by W. R. Dickinson, of Steubenville, Ohio.
1826. - A gricultural school founded as prirate institution at Griznon, near Par's. The whest agricultural inatitution in France.

18:6.- The tirst drove of logs on record as heinf received at Chionso were driven from the TVabash rivar during the winter of 1826-7. They were brought in by Gurdan $s$. Hutbard, who sold them to the soldiers at Fort Howard and the citizens surrounding the fort.

18:7.-Mr. l'ars.ns forham, of Cincinnati. old seeds ind was one of the early Western merchants carrying a supply of seeds.

182\%. - Iirst slanghter house in Chlcago built of logs l,y Arehilsald Clybourne. The irst drove of hogs was received at Chicago this year.

18:\%. Octoher :31.- "I Iattler," (pedigree unknown, maced the trottint record for two iles at $5: 24$.

18\%.-In this yคar, in Wngland, a Mr.Clark of Canwick, exhibited two wether Lineoln heel in the Lincoln market. The lleeces had yielded twcive pounds each. When slaughtered, the carrass of the larger ong Weighed 261 pounds; each of the fore quarlers weinhed 73 pounds, and the hind quarers $57 \frac{1}{6}$ pounds. On the top of the rib the lid fut measureat nine inches in thickness.

18:3. - The enrliest recorded apple tree blanting in Kansas was in this year by $\mathrm{Rey}$ rend Thomas Johnson, near shawneetown, on county

18:27.- The lilea of contensing milk to make it kepis better occurred this vear to a French chemist named Appert. Seven yeary later the method of evanorating the milk !n rarefied air to prevent it from reaching the boiline point was first used.

18:7. - In this year Archibald Clybourne opened a butcher shop in Chiengo, and slaughter house on North Franch, south of Bloomingdale Roar. This is the beginning of Chicago's manufacturing and packing terests.

1827.--Statement by Grant Thorburn: "Besides good seeds good rardeners are necessary in making a garden flourish.

18:\%.-As marking the Gevelopment of the Western country it is recorded that in this year a permanent settlement was made by white men on the west bank of the Missour river. It was first protected by a military cantonment afterwards called Fort Leavenwortl, in honor of Colonel Henry $\mathrm{H}$ worth, the commander of the troops.

1827. Thise South Carolina Railroad Comyany organized and operated by horses.

18:8.- "A Treatise on Iorticulture," the first comprehcnsive book on the subjetiam Prince, of Long Island.

1838. - Nicholas Iongworth, of Cincinnati, by introducing native vines or their seerllings, produced from Catawba and Isabella srapes wine of a high marketable value.

1828. - A Mr. Corhett attempted to raise Indian (American coru) in England, He

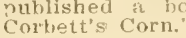

1828.-A: Fast Hartford, Conn., Timothy Deming first undertook the manufacture of lorse collats. He invented the short strow vollars and the blocks on which to make them.

18:8.-In old market report. From the Indianapolis Inurnal, July $3 \mathrm{~d}$ : "Market at this place-Flour, $\$ 2.50$ per 100 pounds; corn meal 50 sents per bushel; bacon. $S$ cents per pound and much in demand. A scarcity of the latter article may be attributed to the number of hogs which were driven from this section of the country during the last fall to a foreign market." "The foreisn market in all probability was Cincinnat.

1828, August 3 d.-Birth of Andrew $S$. Fuller, farmer, mechanic, horticultural writer and improver of llowers and fruits. He died in 1896 . His "Small Fruit Culturist" is published in several languages.

18:8.-A treatise on the rearing of silk worns by Ir. De Hazzi, of Munich, was iranslated from the German by Mr. James Tease, of Washington, D. C., by order of the United States Congress. 
1828. - The following item appeared in the newspapers in November of this year: "We are informed that Mr. Israel Cole, of the season 16,000 pounds of cheese from the milk of only twenty-eight cows, being on an average $0 \ddot{i} 571$ pounds to each cow. His cheese is of the best quality and fetches ivith his established customers in New York one or two cents per pound more than that of ordinary dairies. The average price of cheese at this time was $121 / m$ cents pel pound.

1829.-A M R. Riley and Mr. Richard Jones were awarcied medals by the Australian INelv South Wales) Agricul‡ural Society for intrortucing Saxony sheep into Australia.

18\%9.-Ar act of Parliament passed in Fngland reoulating the package, weight and arle of intter.

18:8. - In this year Peter Hayden, of Cummington. Mass. commenced the manufacture of harness and saddlery at Auburn, N. Y. this being the foundation of the largest American saddlery house, So great was his uccess that for the time being the importa. ion of foreirn saddlery ceased almost en turely turough his eflorts

18:9. - Topgillant, a son of Corlander, dam y Bishou's Hambletonian, established the three-mile trotting recort of $\delta: 11$.

18:9.--Andrew Jackson, President of the

United states, and served eight years.

18:9.-The soy bean first grown in America in the botanic garden at Cambridge, AI: 5 :

18:29, September $7 \mathrm{th}$, - The first pacer men croned in the history of the light harnes: turf', Bowery Boy (pedigree unknown), established the two-mile pacing record at $7: 0432$

18:9.-First locomotive engine tried on American continent to run on rails imported hy the Delaware and Hudson Canal Comrany. Tt weighed seven tons and was considered too heavy. The engine was known as the Stourbrige Lion.

1829, September.-The first number of the American 'Turf Register and Sporting llagarime was issued in New York, with lohn s. Skinner as editor. Ten years later this paper was absorbed by The Sipirit of the Times.

1829.-In ths year the first poultry incubator constructed was exhibited in London, F.ngland. It was a hot-water inculvator, and was not at all satisfactory.

1829. Whe tomato first sold on the market n Fhiladelphia.

1829. - The Jonathan apple originated in New York about this year.

18:9. - Straw and grass first utilized in the Tnited Sitates for the manufacture of paper by G. A. Schyrock, of Philadelphia.

1829. November $26 \mathrm{th}$.-Great inundation of the Nile, in Egypt, begins. About 30,009 people perish by the overflow.

1830.-First practical locomotive engine for every-day work built at West Point Foundry, New York, for the South Carolina Railroad.

1830. - In the early part of this year the 13. \& $O$. Bailway was finished from Baltimore to Ellicott Mills, a distance of thirteen miles, It was operated by horses.

1830 -Prince, in his "Treatise on the vine," purlished this year, described eightyone native grapes of America. Two or three thousand varieties have been disseminated since. which are the offspring of our nativo species.

1830.-Oxford Bown sheep originated by a rross of Cotswolds, Hampshires and probably Southdowns.

1830 - Iersey cattle first imported into the United States from the Channel islands.

1830.-The vacum van erected in sugar house by Mr. Thomas Morgan in Louisiana, the pioneer of these appliances.

1830.-Major Knox, of Danville, Ky., great breeder and prize winner, commenced breeding jacks and jennets.

1830.-Wm. Ensign, of Wilbur's Basin, Saratoga county, N. Y.. commenced breeding red hogs.
1830. - Light one-horse wagons first appeared in Connecticut.

1830.-Wm. McCombie, of Tillifour, Scotland, founded a herd of Aberdeen-Angus cattle.

18:30, June-In the American Turf Reg.ister and Sporting Magazine a contributor suggests that troting matches at regular periods would be as useful as the running aces hy thornughtoreds.

18:0.-Jonathan Curran of Murfreesboro, enn., started breeding jacks and jennets. 18:0.- Tohnson grass introduced into this 1830.- Javan clover first coming into hotice in this country. It was an accidentil introduction from Japan.

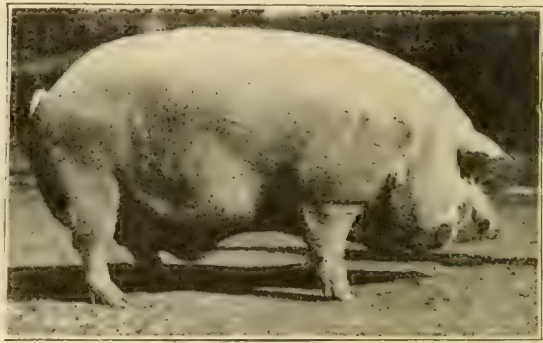

CHESTER WHITE BOAR-EXPORT, as two-year-old, weighing 700 pounds; was Exhihiter by J. W. Dorsey \& Sons, of Perry, i1. The st Louis Fair referred to is the Great St. Louis Fair, first openerl in 1856.

1830.--First appearance of the Chester White hos in Ohin. Feeland and Isaac Todd browght a pair with them from East Haven. Conn. to the vicinity of Wakeman. Three years later. Ioseph Haskins also brought a pair from Massachusetts.

1830. - In this year, in his "Treatise on the ine." Mr. W. H. Prince enumerates eightyight varioties of American grapes.

1831, January 1st. - The Genesee Farmer rounded by MIr. Iuther Tucker at Rochester. $N$. $Y$ and was the forerunner of The Country Gentleman, the oldest agricultural periodical in the world, having been published continuously and without interruption.

1831. - In this year superior steel ho's made at Pittsburgh were sold at $\$ 4.50$ per dozen. Iron and steel were low in price at that time.

18:31.-. The steel soring (prong) pitchfork introducer and patented in the United states in this year by Charles Goodyear, of r'hiladelphia.

1831.--Denjamin Warfield, of Lexington. $\mathrm{Ky}$., purchased the first pure-bred Shorthory cow owned by him. Foundation of Grasmere horthorns.

1831.-Prince, the naturalist, gave the lirst native raspluerry to come into cultivation its proper name-Common Red. It had een callex Fnglish Red.

1831.-Redfield, investigator of weather comditions, published his first essay, describ. irg action of storms and hurricanes.

1831.-Silk Culture Manual published i) H. Cohb distributed by Commonwealth of Boston and the United states Senate.

1831- - S. C Parkhurst opened a reed storo in Cincinnati, Ohio, and did a large trade in rass and clover seeds.

1831.-- In this year The American Farmer described 3 , nichine invented by Thomas $D$. Jurrall, of Geneva, N. $Y_{\text {., for the purpose }}$ of cleaning clover seed.

1831. December 10.-The Spirit of tho Times, great sporting paper, started as a weekly, with Wm. 'T. Forter as editor, in New York City. The last issue of this paper was in December, 1902, when it was consolidated with the Chicago Horseman.

18:31. - Yowatt, eminent writer on live stock subjects, mentions Normandy, in France, as noted for its horses. 
183:- - Alexander Riley of New South Wales, imported thirteen pure-bred Angora koats from France, receiving them at the port of Sydney. On account of death in the family, these goats were afterwards dis. persed. They were the first New South Wales Angoras.

183:- Messrs. Heathooate \& Parker, of Fingland, employed traction steam engines in cleating a large tract of manshy ground lying between Manchester and Liverpont which had been considered unreclaimable l.y any other means at hand.

183:--I.ate in this year Charles Cist, of Cincinuati, instituted the first definits

18:3. pork making in the West.

1833. - Ohio Importing Company organized ly Allen Trimble, Duncan MicArthur. Fellx lienick and others to immort cattle, princtmatly Shorthorns.

183\%.- The first lot of cattle was packed and barreled in Chicago by Geo, IV, Dole for Oliver Newberry, of Detroit, Mich the number being 150 head, They were driven from Wabash and cost $\$ 2.75$ per 100 pound for the net beet, the hides, tallow, etc. lieing thrown in by the seller. The cattle were slaughtered at what is now the corner then the ligh prairie. In December of the same year Mr. Dole also bought and slaughtered the first hoss ever packed in the IVest. there being $33 \mathrm{~S}$ head, average unknown, but cost three cents per pound on foot. The 150 head of cattle referred to in this item Ilickory Creek, IIl. It must be remembered that it was salt-beef packing, largely for the supply of sea-going vessels. This salt-beef packing industry was displaced to a large extent later by dressed-beef transported in refrigerator cars, although salt-beef packing is not a lost art, by any means.

1832.-A pair of Jersey red pigs imported from spain to Salem, N, J.

183:.-Mr. Thomas Hogg devised a system representing important principles of hot water heating for greenhouses.

18:32.-Kenarick, in the "New American olchardist," suggested the blackberry as heing worthy of cultivation.

183\%.-Mr. Jonas Webb, of Suffolk, Ensland, recorderl as successor of John Eliman in improvement of southlown sheep.

1832.-Mr. Hawes, of England, imported Berkshire swime at Albany, N. $\mathrm{Y}$.

18:2. - In this year Mr. David Bradley; timmous as nianufacturer of agricultural implements, commenced work in plow making at Syrcuse, N. Y. Three years later he removed to Chicago to help erect the first foundry there and was the first man to bring pig iron into that city. The establishmerit soon began the manufacture of llows. He worked at the bench wooding "Garden City Clipper" plows, whose name and fame have become world-wide. Leaving the employment of others, he soon had a plow shop of his own, and for fifty years saw it growing to larger and larger proportions, right in the heart of Chicago, until it became one of the largest manufacturing establishments of agricultural implements and compelled him to get larger ground space. Which he finally did in the town which saw fit to honor his coming by taking upon itself his name. Mr. Bradley died at the age of 87 years, the oldest plow maker in the United States.

1833.-- Product of wheat on Island of Jercy. Five-years' average ending this year was forty bushels per acre.

1833.-- In this year a royal decree in France established the Govermment Stud lBok, which had considerable influence in the improvement of French horses.

1833. - The Maine Farmer established at Augusta, Me.

1833. - Isaac Hoskins moved from New Bedford, Mass, to Wakeman, Ohio, carrying with him white hogs that helped to establish the Todd Improved Chester Whites.

1833, November 19 th. - A patent for a method of eutivating or working land by steam power was first issued in the United States to E. C: Bellinger, of South Carolina, but the invention never went into general use.
1833. - In this year, in the New American Orchardist. William Kenrick mentlons cwenty-three varieties of figs.

1833.-Daniel l'ratt, a native of New Hamphire, commenced the manufneture of cotton wins in Autauga county, Alabama.

1833.-Antoine LeClaire established an orchard at Davenport, in Scott county, Iowa. This orchard contained about 400 trees. which were brought by boat from. Cincinnati. Ohio, and was the second orchard tarted in that stite.

1833.- - In this year four tons of silk cocoons were broduced in Windham county. Commericut. The interest in silk culture it partcok of the nature of a craze insteacl a legitimate industry.

1833.-Charles Mason Hovey pegan a serles cf experiments and finally produced Hovey's ing berry for thirty years and actually caused strawberry culture to became a popular and profitable industry. It was the first strawberry suited to climate and conditione of America. It is now extinct.

1833. - William Smith was born in this year. He invented the stump puller in 1861 He died in 1910 at LaCrescent, Minn.

1833.-Boston. the phenomenon, a thorongred horse, foaled in this year, He ahoe, virginia. IJe was "a horse with backbone like a frnce rail and a stifle like a Durham buil." He ran a mile in the first lieat of a longer race in $1: 46$, which was three-fourths of a second faster than the record at that time. At the height of his career his owner advertised to match lioston against any two horses in the world to run four-mile heats for no less a sum
than $\$ 45,000$, taking one horse in one heat and the other in the next. The challenge tood in the alvertising columns of the pir't of the Times without takers.

1833.- Rice successfully threshed out in the Southern States by animal and steam power.

1833. - Sylvester Marsh arrived from the Vast in Chicago, and after working in the new tnwn three years projected a packing house on Kinzie street, near Rush street. they packed 6,0ino hogs in 1\$36. He useu to go 150 miles to the Wabash river driving cattle, hogs and sheep and whatever he could pick up on the way. The canal hrroads were running into Chicago.

1833. December-Obed Hussey, of Cincinnati, Ohio, received a patent for a reaping machine which olitained favorable recognition in several states. Five years later a manufactory was established at Baltimore.

1834, October.-A steam plow was tested by the inventor, Major A. Tyrrebl, in Genesee county, New York.

1834.- - The lioval Jersey Agricultural society held its first meeting on January 18th. This society played a very important part in the early development of Jersey attle and continued to do so.

1834...First breeding of Berkshire swine on farm of Richard Gentry, in Pettis county. Missouri. He was uncle and steptather of N. H. Gentry, the famous improver of Berk-

1834-Old Grannie, calved on the farm of Wugh Tatson. of Keillor, Scotland. First cow recorded in Aberdeen-Angus lterd Book. This famous cow lived to be thirty-five years of age.

1834-Edwin Forerst, black gelding of unknown brecding, reduced the trotting record to $2: 3]^{1 / \mathrm{s}}$

1834.-A cotton-seel oil mill erected at Natchez, Miss.

1834.-A "Howard" vacuum pan established in the sugar house of Mr. Valcour IIme, planter, of St.Janies Parish, Louisianu. 1834. - Shorthom cow Princess sold by Ir. Clay, Jr., of Kentucky, for $\$ 2,000$.

1834. March.-The Cultivator, an eariy agricuitural paper, was founded by Jesse Buel under the auspices of the New York State Agricultural Society. Edited by Judge Buel, who afterwards became proprietor. 
1834- - ITm Fullerton, of Ardovie, Scotland. started a breeding herd of AberdeenAngus cattle.

18:34. - Tyler Stickney Hock of Spanish Ievino shcep estahlished at Shoreham, Vt.

1834.--Importation of heifers Rose of Sharon and Young Mary, famous for shorthorn excellence.

1834.- $A$ vessel from feghorn arrived in America, and a part of the cargo was it small shipment of towls, which were at once named "Jeghorns." They became populat on account of their good laying and non-sitring qualities.

1834. - First patent for his reaping machine issued to Cyrus H. MeCormick, of Rockliridge sounty. Virginia. It was worked in 1831, improved many times, and "a great boon to this country and foreign lands."

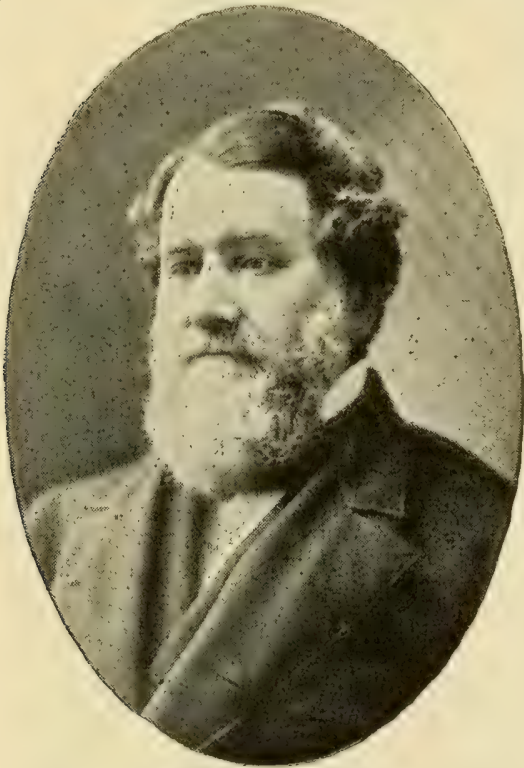

CYRUS HAIL MCCORMICK, inventor of the reaper. Born February, 1809; died October, 1865. Inventor of the first practical reaping machine

183.5.-The Blondgood pear brought into notice by James Bloodgood, of Flushing Long [sland.

1835.-A. C. Mrore and D. M. Magie, in Ohio. two of the originators, breeders and principal improvers of Poland-China swine.

18:35.-Niorton's Virginia grape-an offspring of the wild summer grape of the Southern and Middle States-round on Cedar Island, in the James river, near Richmond, Virginia.

1835. - Iifty miles were trotted in three hours and fifty-seven seconds by a horse of unknown pedigreo called Black Joke.

1835.-Mr. "Thomas Ferguson, of Kinoctry cotland, founded a herd of Aberdeen-Angus cattle.

1835. - In Warren and Butler counties, Jhio, a local breed of swine known at this time as the WVarren County Hog and the "Big spoited," were afterivards included us Poland-8hinas.

1835. - James Smith, of Deanston, England, promulgated his system of thorough draining and deep plowing.

1835 -Captain James Knight, of Nashville, Tenn., bought a fine jack in Virginia named John Full, third desceridant of loyal (xift

1835.- Lord Western of England introduced Neapolitan swine from. Italy to improve the Essex pigs.

18:35.-- Baling presses known to be made in the state of Maine about this time.
1835. - In Fngland, Sir Robert Peel presented a farmers' club with two iron plows, went. back afterwarts to see the work done with them, and found the plows with wooden moliboards again at work. "Sir," said a member, "We tried the iron and be all of one mind that they made the weeds row.

1835.-A new variety of potato callea Perkins' Seedling, was originated at this time by planting a seed ball a year or two efore.

1835. - In September of this year the first Acricultural Fair in Missouri was held at Columbia, Boone county.

1835. - The Magazine of Horticulture established at Boston. Mass., by C. M.Hovey.

1835. - By this time extensive greenhouses had been erected in the vicinity of Nely York, Boston and Philadelphia. One estal. lishment at Long Island had houses aggrerating 400 feet in length.

1835. - It was announced in December of this year that a Mr. Bailey, of IIartford, Conn., had invented a cast iron grist mill, which had becn tested by grinding wheat rye and corn as well as most kinds of proventer, corn in the ear, oil cake, etc. and its work was pronounced by experienced millers to be equal to that produced by the common millstones, One horse could grind ten bushels of rye or wheat per hour sufficiently fine for Hour. The cost of a mill with the machinery for a horse to work it was mentioned at $\$ 250$ to $\$ 300$.

1836.-Daniel Webster, the statesman, invented a plow for work twelve and fourteen inches deep, cutting a furrow twentyfour inches wide. It is still in existencetwelve feet long, the beam twenty-eight inches from the ground. and the landside four feet long. It was designed for a field wnich was full of roots.

1836- - James Jackson, of Alabama, sent to England for the best thoroughbred there, and the horse imported was Glencoe. He was sire of Pocahontas, the great thoroughbred matron. Glencoe died at the age of 26 years: owned by A. Keene Richards, of Kientucky

1836. - Tomatoew began to be cultivated in this country as food; had been raised wrincipally for ornament under the name "love apples."

1836. -The Western Province Agricultural Society of South Africa offered a silver cup value fifty pounds sterling, to be awarded for the best 100 pounds of Merino wool, and had to be won three times in succession before becoming the property of an indiridual cwner. Won in 1846 by Reltz, Van Breda \& Jnubert, original importers of Merinos into that country.

1836. - The Baltimore Belle and the Queen of the Frairies Roses named this year by a Baltimore florist, They carne from the Michigan Rose.

1836- - Erastus Corning, of Albany, N. $\mathrm{Y}$. imported shorthom eattle.

1836.--Joel Nourse \& Co., of Worcester. Mass., commenecr the manufacture of garicultural inplements and made impostint improvements on the cast-iron plow.

1836.--On July 4 th of this year the United Staten I'atent Otfice was made a separate bureau, and Hon. Henry L. Eills. worth, of Connecticut, tvas Commissioner. $\mathrm{He}$ had been a practical farmer, and he considered it within the proper scope of his office to help farmers by distributing seeds and plants.

1836---Cantain James Knight, General A. vilson and General I. M. hnight of Mar shall county, Texas, bought the Kentueky jack Maringo Mammoth. Sold at nine years old to 1. W. Knight for $\$ 2,160$. This jack won many premiums.

1836. - Templemoyle Agricultural Seminary established in county of Londonderry, Ireland.

1836.-Devon cattle imported by Mr Vernon, of Neiv York state.

18:6, Oetoler 29th.-At Felix Renick's farm, Ross county, Ohio, imported Shorthorns sold at an average of $\$ 803.25$ for forty-nine head Seven bulls and seven heifers each sold for upwards of $\$ 1,000$ each. 
1836.-Pay, a pacer of unknown pedigree, vaced two niles under saddle in $5: 041 / 2$

1836.-Char!es Mason Hovey, an American horticulturist. called attention to the change in color produced in the flower calceolarius by the introduction of a different colorer species. An evidence of distinct results in plant breedinz:

1836. Mr. H. Clay, Jr., of Fayette county, Kentucky, began importing shorthorns.

1836.--Lew Jotanieal Gardens in England foundeal by Sir WV. Hooker

1836. November. - The French War Deportment, after three-years' experiment, could not determine whether or not rlanders in horkes was a contagious disease.

18:7.-Martin Van Buren, President of tho United statex, and served four years.

1837--Ross' Phoenix strawberry rased by Alexander Ross, of IIudson, N. I., from Keene's Seedling

183\% October 24th-Final sale of Ohio Importing Company shorthorns. Fifteen head averaged $\$ 1,071.65$

183\%.-Lewis $\mathrm{F}$. Allen, in his "American Cattle" mentions appearance of a fine Galloway cow in Philadelphia.

18:37.-I.egislation in North Carolina to prevent the driving of cattle from South Carolina or Georgia through that state on account of the cattle lisease caused by them.

18:3\%.-Amos Cruickshank, of Sityton, rear Aberdeen, Scotland, first began breedins shorthons, foundation of what are now called Seotch or "Cruickshanks.

1837.-Henry Clay, 2:35, famous trotting sire, foaled in this year; bred by Geo. M. Patchen, of New Jersey, This horse was aftervards sold for $\$ 1.050$ (which was a dollar a pound). He made his record of $2: 35$ in a five-heat race which he won, having been driven ninety-eight miles the day before.

1837. - Three steel plows made by hanil this year by John Deere, said to be the first steel plows made.

1837.--Henderson Lewelling started nursery near Salem, Henry county, Iowa, which was continued by his brother John until 1850, when he closed out the stock and went to oregon.

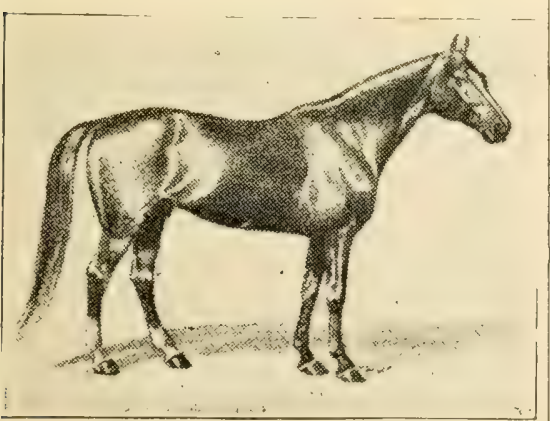

SEELEY'S AMERICAN STAR.

1837.-Seeley's American Star, recorded as American Star, 14, foaled in this year, bred by Henry $H$. Berry, of Pompton Plains, N. J. He is noted as sire of speedproducing brood mares.

1838. - First Chicago grain elevator established this year and made the first shipment of wheat.

1838. - Royal Agricultural Society of Enrland established with 466 members.

1838. - First direct importation of Shorthoru cattle from Eingland to Indiana by $\mathrm{Mr}$ Chris. Whitehead, of Franklin county.

1838. - The metnod of imbedding glass in vutty in construction of rreenhouses known to be in use in Fingland at this time.

1838. - Shorthorn cattle first introduced into France.
1838. Glasnevin Training Farm estah. lished in Ireland by Commissioners nf National Bducation.

1838. Herkinire hogs introduced into Canada.

1838. - Iutel Jelted eattle first imported int the Iinited States by D. H. Haight, ot Goshen, N. Y.

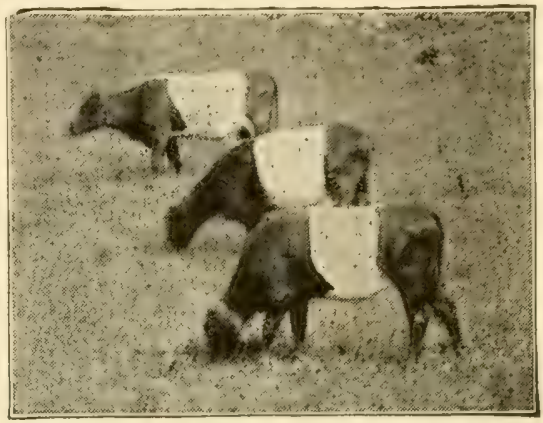

DUTCH BELTFD CATTIE - Bred and owned by G.G.Gibbs, of Marksboro, N. J.

1839. - In this vear the horse Dutchman obtaineal a mile trotting record in $2: 32$.

1839 - In this vear the first cargo of thax seed imported in America arrived fron Russia. The Tnifed States had already ex ported as high as 292,460 bushels of tlax seed in one year.

1839. - In the summer of this year R. II schombursk, a German explorer, returnec from 'Pritish Guiana to london with collections of the magnificent water lilies known as the Victoria Regia and the Clizabelha Regia, and several new species of orchids-one of which has been named for him the Scliomlurgkia orchida.

1839. - Dutchman, by Tippoo Saib, Jr., ani whose dam was by a son of Messenger, trotted three miles arainst time under saddle in $7: 3: 3 / 2$

1839.-Denmark, a thoroughbred horse, foaled in this year, is first foundation sire of the Kentucky saddle horse. He was by Imp. Hedgeford, out of Betsy Harrison.

1839.-Edward Harris. of Moorestown. N. Y., earliest importer or high-class iraft horses, imported two draft mares and the balion "Diligence," They were Fren.h horses.

1839.-Messrs. Bagg \& Wait, of Orange, county, New York, made large importations of Berkshire wibe from England.

1839, March 3a.-During the closing hours of the Twenty-fifth Congress, Hon. Henry 1. Ellsworth. Then Commissioner of Patents, secured an appropriation of $\$ 1,000$ for "the collection of agricultural statistics, invesigating and promoting rural economy and the procurement of cuttings and seeds for gratuitous distribution amongst farmers.' 'his is the orizin of the United States Defartument of Asriculture.

1839. - N. I weonard, of Cooper county, Missouri. founded the Ravenswood herd of Shorthorns, first perigreed herd wost of the Mississippi.

1839.-Oxford Royal, the first English vational Show. 'Thomas Bates' Shorthorns on sreat houns.

18:39. - Fayette County (Kentucky) Importing Company sold twenty-six Shorthorns at an average of $\$ 627.35$ per head.

1839.--The Boston Cultivator establisher at Poston. Mass.

1839, June-Hereford cattle imported into this country by IV. H, Sotham.

1839, Octoher 3d.-The first mile below 2:30 was by Drover, who in this year pacer it 2:2s at Beacon Course, N.J.

1810.-Dr. Perrine at Indian Key, Fla., introduced the Mango plant from the West indies. 
1840.-About this year Plymouth Rock fowls were originated near Woodstock, Vt. Messrs, Giles, Clark, Thayer, Spaulding and Rev. H. S. Ramsdell being the originators The Plymouth Rock was the result of a cross of American Dominique males with single comb black Java females.

1840.-The sroup of carnations now most cultivated in America, known as perpetul flowerinz, tree or monthly carnations, originated in France about this year, as the result of crossing and selection.

1840, - In this year the subsoil plow, adapted to teams up to six horses, was introduced from Sicotland into the United Sitates.

1840.-First Cheviot sheep imported into the United States of America.

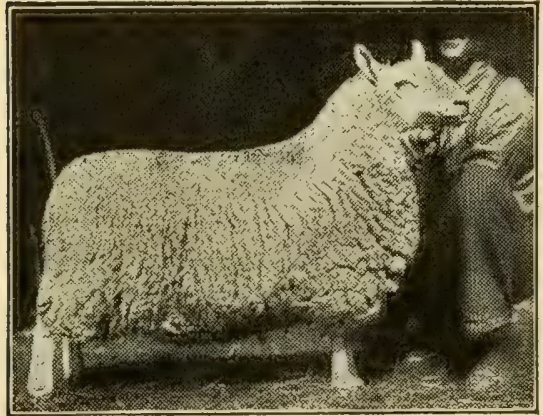

CHAMPION CHEVIOT EIVE at the Indiana and Illinois State Fairs of 1900 Exhibited ly J. Kiolin, of Brooklyn, Wis.

1810. June 10th.-Furs-The St, Louis Bulletin of the 5th said: "Two Mackinaw boats arriced here yesterday from Iowa, loaded with buffalo rohes."

1810. - The Angora goat first imported into Cap. Colony, South Africa, by Colonel Henderson, an officer in the Britisls army.

1840, January, - Mr. Luther Tucker, Fochester, N. Y purchased The Cultivator ipon the death of the owner, Judge Buel consoliditing it with his paper, The Genempe Inmer, under the name of The Cultivator

1840 - Twenty ewres and two rams selected from the lambouillet Merimos of France IVere imported into the United States by D. C. Collins, of Hartford, Conn.

1810.-Abcut this year Mr. Ephraim Bull, of Concord. Mass, discovered a wild grape vine, from which he grew, developed, culti vated and improved the grape now ealler the "Conrord." It is ronsidered the greatest advance in grape growing in this country.

1840.-Justus von Ifiebig published famous work, entitled "Organic Chemistry, in Its Relation to Agriculture." He estab. lished in the popular mind the theory of the plants almost entire dependence

mineral food. He founded artificial fertilization: demonstrated the value of potash a rlant food; and many other valuable dis coveries are attributed to him.

1810. - Imported jack Knight Errand brought to Maury county. Tennessee; owned hy Mr. Thomas: afterwards sold to General J. Pillow.

1810.-P. T. Barnum and $W$. $R$. Coleman imivortfi Iutch Belted cattle into the inited States.

1810.-Mr. Fisher Hobbs, tenant of Lord Western, in Fngland, established accepted iype of Essex hogs.

1840.-Colonel Wm. Johnson, plantation ovner near Marion Junction, Alahama, first nowed the grass which now bears his name.

18.10.-A. C. Clark, of Jefferson county, New York, originated breed of swine called Cheshires. Sires were large white Yorkshires and bred on the best sows of his section.
1810.-Mowing machine improved by $\mathrm{Mc}$ Cormick.

1840. - Cheese exportations from the United States began to be of importance. mainly from New York, Vermont and Massachusetts.

1841. - First sheep introduced into New Zealand from New South Wales, Australia. 1841.-In this year a few bushels of lover seed were sent from Cleveland, Ohio (1) Canada. The first record of this char-

1841. - Tilliam Henry Harrison inauguated President of the United States, March $1 \mathrm{th}$, and died April $4 \mathrm{th}$ of the same year.

1811.-John Tyler elected Vice-president. wiceneds to the Presidency of the Unitert States. April 4th, and serves nearly four 1841.--The Murrain, or "vesicular epizoo1jc," appeared in "ngland, supposably introilucerl by foreign cattle; affected all live ck excent norses.

1841. - Mirst commercial record of disposition of American cotton crop, season of 1841-42. Crop, 1,684,000 bales, disposed of as ollows: 'To Great Britain, 936,000 bales; to Europe and Mexico, 480,000 bales; homo consumption, 268,000 bales.

1811.- (hina fertilizer introduced into 1811. - Grade llereford ox exhibited by $\mathrm{Mr}$ sust at the first New York State Fair, veighing 3,700 mounds.

184\%.- Fivst important importation of wool into lingland from Australia, about thirteen million pounds during the year.

184\%-Professor Lotv said: "The Dorsets are the most productive of milk of any of our races of sheep.'

$181 \%$--In this year the Erie Railroad first jecame engaged in the transwortation of milk and established a freight rate of onehalf cent per quart.

184\%, Gray Clyde, 78, Clydesdale stallisn, imported by Archibald Ward, of Markham. Ontario, Canada.

184\%, Anril 11th - French experiments inally determined ylanders in horses to be contagious disease.

1812.-Early in this year Philo Gregory, of Chester, N. Y., was induced to try the experiment of shipping milk by rail to New rork City. The termius of the Erie Railway vas then at Goshen.

1812.-Professor I ow mentions improved ivrshire cattle as owing superior charactur mixture of races from the continent of Eurnpe and the dairy breed of Alderney.

1842.-It was not until after this date hat Robert Fortune, naturalist, went to china and sent back many speeimens of flowers, that the White Chinese Wistaria ind Fortune's Yellow Rose hecame known here.

184:-Agricultural Chemistry Association (first of its kind) organized by Mid-Lothian. Scotland, tenant farmers, at suggestion rif Mr. John Finnie, of Swanstone.

184\%-Professor Jow classes all the Channel Islands cattle under the name $n$ ? one of the islands. "Alderney."

1842 - Highest price of upland middling cotton for the year on the New York market helow 10 cents per pound for the first time in history. Highest price of the year, 9 cents; lowest, 7 cents.

1842. - Professor Low, in his book entitled "Domestic ! Animals of Great Britain"' attributes superior condition of Noman Inorses to abundance of grass and food in that province.

184\% Duke of Northumberland, famous Bates shorthorn bull. at three years and eight montlis weished 2,520 pounds.

1812. - American Agriculturist, great agricultural naper, founded by A. B. Allen, assisted by Richard I. Allen.

1812.-Meeting of Booth and Bates Shorthorn cow's at York, England. The ten-yearli Bates Duchess, 34 th, took the premiun ver the Booth cow Necklace.

1842. - Tohacco warehouse established at Clarksville, Tenn. 
1843.-The Southern Cultivator established at Aurusta, Ga, by J.W \& W. S. Jones.

1843. - Martin Doyle, writing in this year, asserts that the Cleveland IBay horse is a descendant of the old war horse of Great Britain.

1843.-Philo Buckingham bought of Stephen Atwood, of Connecticut, the best Spanish Merino ram that Mr. Atwooc would spare and two cwes,
to Muskingum county, Ohio.

1813. - In this year, according to the United States Department of Agriculture Year Book of 1904, Reuben Ragan, of Put nam county. Indiana purchased a part of the stock of Josiah Iindley, who had conducted a nursery at Monravia, Ind. Among it was a long-bodied seedling pear tree in peir. 'This was a rare and high-priced variety at the time, and was given special uttention. After being attacked by the pear attention. After being attacked by the pear it finally produced a delicious late fall pear of nedium size. It was afterwards called the Philopena by the originator.

1843. - In this year George Funk, a welllinown stockman of McLean county, Illinois, drove his first cattle to Chicago. then beins sixteen yaars of age. He drove from Funk's Grove, Mclean county, to Chicago in twelve days. Jn an address before the MeLean County Historical Society of Illinois, sixty years later, speaking of the
cattle sold and delivered in early days, re said: "We sold by the dressed weight, th packer getting the hide and tallow.

1843. - According to the book entitled "Industrial Chicago," the packing house of Dyer. Chanin \& Wadsworth was established on South Branch, near North street. During that winter Archibald Clybourne killed 3,000 cattle, which were shipped to New York early in the spring. Others followed Clylourne's example, for beef could be bought ior $11 / 2$ to 2 cents per pound, according to the grade of the cattle. The packers cleaned out the Western country of its live stock and made hay while they could, rewardless of to-morrow's demands. This is ahout the first item which mentions the packing relates to salt beef.

1843. - In this year, at Chicago, corn solu for $1 \mathrm{~s}$ cents per bushel, and

1843. - The new Diana grape, a seedling of the Catawba, first exhibited before the Massachusetts Horticultural Society of Baston by Mrs. Diana Crehore, of Milton, Mass, It was named for her.

1813.-First Agricultural Experiment Station established on his own estate, about forty miles north of London, England, by Mr. John Lawes.

1843. - A pear treo planted by Mr. Ockletree in 1805 in Illinois, about ten miles north of Vincennes, produced 184 bushels of pears. The girth of the tree one foot from the ground was twelve feet, and nine feet from the ground it was $6 \frac{1}{2}$ feet.

1843.-Plenro-pneumonia in cattle first introduced into the United States in the vicinity of New York City.

1814.-- "O!d Jack," a famous AberdeenAngus bull, bred and raised by Hugh Watson, of Kolllor. Scotland, sold for a hundred guineas ( $\$ 50 \mathrm{~s}$ in American money)-a big price at that time.

1814-In January of this year the Price Current, famous statistical paper in regard to packing-house interests and products, was started br A. Peabody.

1844.-It was reported to the editor of the American Agriculturist by $\mathbf{M r}$. Wm. H

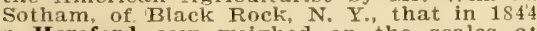
a IIereford cow weighed on the scales a Albany 2,313 pounds alive. Mr. Bennett, of Brighton, Mass, sold this cow to a Boston butcher for $\$ 150$. She was exhibited in Bogton for a month at a shilling a head Her beef was of the finest quality, and the nwner exhihited the quarters round the cit: on a warm, sunny day, and spoiled the whole of it.

1814.-Towards the close of this year vadsworth, Chapin \& Dyer, Chicago pork packers, packed a tierce of beef for the English market, the tlerce being made by Hush Maher. During the winter of $1845-46$ they killed no less than 2,000 cattle brought they killed no less than 2,000 cattle brought indiana. The price on foot was then about 52.50 per 110 pounds. This is the beginning of salt-beef packing for export, the business upon which stockmen had to rely to disposo fheir surplus before the better methods f canning and refrigerating of beef were nausurated.

1814-Boussingault, an eminent French hemist. published a work, entitled "Rural conomy, one of the first great books ubon agrieultural chemistry.

1814, - Tenants on New York "patroon" estates refused longer to comply with old eudil customs of paying a few bushels of wheat, or a day or two service per year, in order to hold land under them. This ed oblin clear titles without a subservience to estate owners.

1814.-- Royal Agricultural Society of Ireind organized.

1844. - At Southampton, in this year, the A gricultural Society of England offered IIorn cattle.

1814. - TVilliam W. Plant began the sale of farm tools and seeds in St. Louis, Mo.

1814.- The Touisville (Ky.) Journal men jons a large pork-packing establishment fstablished in this year on Pearl street, of that city.

1844 - First cotton mill erected in Missiscave Hill, Washington county.

1844. First cotton mill in Arkansas rected at Cave iHll, Washington county.

1844.-Dr. Brinckle, of Philadelphia, rower of raspberries, produced an imjortant variety called Brinckle's Orange, Trom an

1844. - Witnesses examined by a comnittee of the Finglish House of Commons agreed that in many parts of that country at that time lands were rented for separato ise of individual possessors from seed timo tu harvest, afler which they were open and common to all for pasturage. They were lesignated "lammas lands," or "open, commonable, intermixed fields. that $\mathrm{En}$ land had free range as late as 1814

1845.-Newtown Pippins from the orchard fobert L. Pell, of Ulster county, Netw harrel.

1845-Tames K Polk, President of the United states, and served four years.

1815. - In this year a Cincinnati journalist published the following: "Our pork business is the largest in the world, not even excepting Cork or Belfast, in Ireland, whense country puts up and exports stranger who moints in that line: and the season of cutvisits Cincinnati during the season of cutting and packing hogs should on no account neglect to visit

1815-Houchton's Seedling, an improved 1rom cooseberry, produced near Lynn, Mass.

1845 - Sovereign, 181, Clydesdale stallion, mported by R. Johnson, of Scarboro, Ontario, Canada.

1815. - An agrieultural school at Cream Hill, Conn. established in May of this year liy Dr. S. Wr. Gold and his son, T. S. Gold. continued in successful operation twentyfour years.

1845 - Dr James B. Davis, of Columbia. 184. sultan in cotton raising.

1815. Hereford cattle introduced into the sland of Jamaica, West Indies, by Mr. Talcolm.

1815, Mr. Norbert Rillieux, of Louisiana, 18cived the idea that the hot vapor arissugar cane juice ing from a vessel of boiling sugar cane concould be user to evaporate the water contained in a second vessel of cane juice, oration in making sugar. 
1845. - French Bros, established a business in Cincinnati for the purpose of supplying fresh milk to consumers, which developed successfilly, leading to the building of a creamery at Lebanon, Ohio, in 1898.

1815. October 13 th-Lady Suffolk, first 2:30 trotter, appeared, making the mile over the Hoboken, N. J., track in $2: 291 / 2$. She was a gray mare, sired by Engineer, dam by Don

1845. - Potato blizht first appeared in England and Ireland.

1846. - The Bleeding-heart Kose finst introlued people, the Jondon Horticultural Society having received from China a single plant.

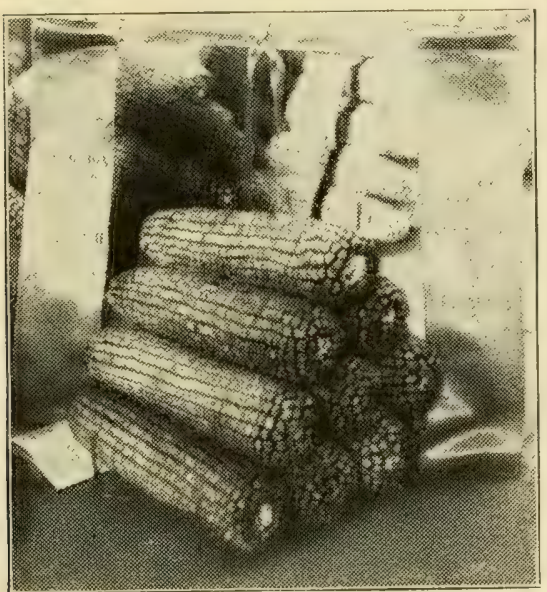

A moctern exhibit of yellow corn at the Illinois State Fair.

1816. Reid's Yellow Dent Corn, a light yellow variety, originated this year with J. L. Reid, of Delavan, III.

1846. The summer of this year was unprecedently hot throughout England, and all the horticultural journals united in pronouncing the bloom of roses that season unsurpassed by the bloom of any previous year.

1816.-First American Shorthorn Heral Book issued by Lewis $F$. Allen, of Black Rock. N. Y

1846.--English corn (wheat) laws abolished.

1846,--The Horticulturist, an influential farm paper, established by $\mathbf{M r}$. Luther Tucker edited by Mr. Andrew Jackson Downing, and discontinued at his death.

1846. - In the early part of this year a $\mathbf{M r}$. J. R. Smith reached Chicago from Nev Jersey. He went down into the state of lllinois and bought. 225 head of good, fat, old-fashioned cattle at $\$ 16.50$ per hear. He drove them to New York and they were the first cattle driven from Illinois to that city of which there is record. In 100 -days' driving over public roads and sivimmins streams the cattle reached their destination the expenses heing $\$ 5.50$ per head, making a tota! cost of $\$ 22.00$. The cattle brought $\$ 40.00$ per head in. New York, netting the enterprising drover more clear profit than the cattle raiser obtained altogether for breeding and raising these good three and four-year-old steers, No truer example can he shown of old-time conditions.

1846. - Experiments begun in New York towards preserving (camning) milk.

1846. - Mr. J. Boydell, of Eingland, constructed an engine that laid its own track as it traveled over the ground.

1846. - The Genesee Farmer for March of this year spealss of the unexpected suc-
cess of the Cortland County Agricultural
School, Mr. Woolworth, the lecturer, addressing twenty-five to thirty farmers once week.

1846. Hereford Herd Book commenced by Mr. T. C. Eyton, of Eyton Hall, Salop, Ensland, in $1 \times 46$. The first two volumes con tained 901 bulls, but no cows.

1847. - First systematic irrigation in the arid West by the Mormons on the land where salt Lake City now stands.

1847-In three years (ending 1847) average wheat crop of Island of Guernsey was serenty-six bushels per acre.

1817. - A Mr. Martin erected a cotton-seed vil mill at New Orleans.

1847. - Extract from the book entitled "The Farmers" Companion." by Hon. Jesse Buel, of Danbury, Conn.: "The new system of husbandry is based upon the belief that our lands will not wear out, or become exhausted of their fertility, if they are judiciously managed; but, on the contrary, that they may be made progressively to increase in product, in rewards to the husbandman and in benefits to society, at least for some time to come. It regards the soil as a gift of the beneficent creator in which we hold gut a life estate, and which, likel our freo institutions, we are bound to transmit un impairec? tis posterity.

181\%.-.Two patents issued by the United States on arificial method of hatching chickens.

184\%.-Millet recommended as a soiling rol in Patent Office Report

184\%.-James IK. Polk, a pacer, whose pedigree has been lost sight of, covered a istance of three miles in harness in $7: 44$.

1818. - Tocld Bros. \& Haskins, near Wakeman, Ohio, bought a boar of what was called the Large Grass 'Breed from Joel Mead, of Norwalk, Ohio, for the improvement of the Cliester White hogs.

1818. March 21st.-Mr. William Saunders, a Scoteh gardener, arrived at New Haven Conn., in serve as sardener for Mr. Bostvick. He vas a great writer on agricultur suliects. He introduced fixed roofs for reenhouses in this country, and for thirtyeight years was in the service of the gov ernment, doing the most important work as landscape artist. He is largely responsihle for the beaufifieation of the Nationa Capital. He died in 1900 .

1848.-David Rankin, famous successful farmer and feeder, fed his first cattle in this year in Henderson county, Illinois. He afterwards moved to Tarkio, Mo., becoming the larcest corn grower and stock feeder in the United States, Ordinary feeding by the year 1900 amounted to 12,000 cattle and 20,000 hogs a year.

1848.-Manual of the Botany of the Cinitei sitates issued by Asa Gray.

1818. - In this year Mr. John T. Alexander. a Virginian by birth, but raised in Ohio, lought land in Morgan county, Illinois, at to 00 Mr Alexander was a great pioneer cattle feesler and dealer, he with Christian Hays being a large buyer and drover of Texas rattle. He used to ship to the Fast by driving to Toledo, Objo, thence to Dunlsirk by lake stenmer, then by cars to New York, a part being afterwards sent o Boston.

1848. -IBull's Ifead Stock Yards, Madison street and ogden avenue, Chicago, established by John B. Sherman.

1818. December. First live stock slipped to Chicago by rail. Millican Hunt, hauling a sled-load of hogs to market, found no snow beyond the Des Plaines river oi Which to draw his piss, chicaso and Northwestern Railroad, then called the Galena western Railroad, then called the Galena Road. His porkers rode ten miles to little engine which also hauled the first load of wheat to Thicago in the same year.

1848.-Alout this time a few Guernsey cattio were owned in the vicinity of Philadelplia, $\mathrm{Pa}$.

1849.-In this year Moyamensing Pine, a straiberry produced from Iovey's Seedling, was awarded the prize offered by the whiladelphia Horticultural Society for the best new berry. 
1819. - At this time the scythe and caststeel fork manufactory of D. G. Millard, near Clayville, N. Y., was manufacturing $j^{\prime}, 000$ dozen of scythes and forks annually hy water power.

1849. - Crown Prince calverl. He was one of the greatest stock bulls of the celehrated Booth Shorthorns.

1819. - Rysulick's Hambletonian foaled in this year in Orange county, New York died in 1376.

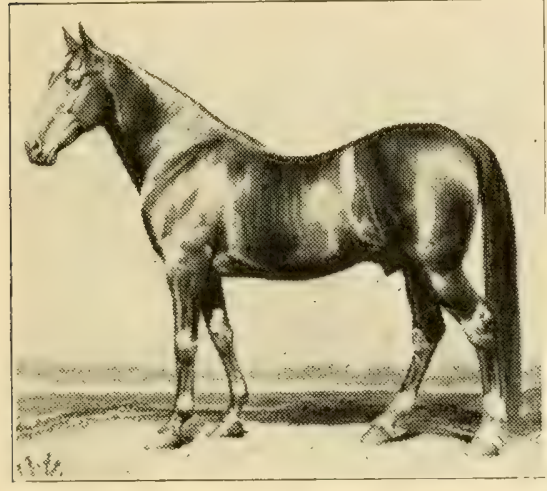

RYSDICK'S HAMBIETONIAN.-Sire of trotters. Pieture taker in his olil age. From copyright photograph, hy permission of Schreiber-\& Sons, of Philadelphia.

1819. - In this year the factory of R. $B$. Junn, in North Wayne, in Maine, turned cut 12,000 dozen seythes.

1819.-The Valley Farmer, afterwards Colman's Iiural World, of St. Lnuis, Mo. established as a monthly by Norman I. Colman, assisted by Wm, Muir and C. W. Murtielt, Associate Editors.

1819.-Zachary Taylor, President of the United states, and served one year until his rleath.

18.9. - Ireguing machine first made in the Champion factory at Springfield, Ohio.

1849. - James Vick began to grow flower needls in New Yorle state.

18.9. July 2d.-Pelham trots a mile in $2: 28$ at centerville, N. Y.. making a world's record.

1849.-Mormons of Utah practice irrigation in agriculture, the first by Anglo-Saxons in the United States.

1819.-Dr. James B. Davis, of Columbia S. C. imported nine Angora goats, a present fromi the Sultan of Turkey. They were two bueks and seven does.

1850.-.-Morre's Rural New Yorker established at Rochester. N Y by D. T Moore, Editor, Hon. Henry S. Randall, LL. D. was Fditor of the Sheep Department, and Dr. Daniel Lee Southern, Corresponding Editor.

1850. - In this year a Shorthorn cow named Crace was killed in New York state. Her live weiglt was 1,795 pounds. She was round, to he with calf. Her calf and appendrges weighed fo pounds. Her dressed carcass weigher 1. pounds, and tand shrinkage, 271 pounds. This is a yield of $S 4$ pounds 6 ounces of This is in yield of $\$ 4$ pounds 6 ounces of
dead weight to every 100 pounds of live weight, making her shrinkage less than 16 per cent. Ife: tongue liver, heart and tripe, if 'weighed. would have reduced her shrinkaye to 14 per cent. Grace was fed by Colonel Sherwood, of Auburn, N. Y.

1850.-Dr. Fiand, of Baltimore county, Marvland, began his work which finally produced the "Trophy," the variety which made the tomato a profitable garden ve:retable.

18.ั0.-John Johnston, a Scotch farmer near Geneva, $N$, $Y$ introduced and arocated a system of farm drainage by tilin.
18n0.-The Wild Goose blum was first wrought to notice by James Harvey, of Columbia. Tenn. Some time before 1850 a man shot a wild goose neur Columbia, and on the spot whero the carcass was thrown the plum came up the following spring. It is our most popular plum, and was introduced by D. S. Downer, of Fuirview, Ky., in the year mentioned.

1850.-Dr. John Gorrie, of Florida, the original inventor of the artificial production of ice, patellted his ice-making machine.

18.50.- The Ingram apple, famous for productiveness and long keeping qualities. originated from planting seeds of "Ralls" sivringfield, Mo

1850. Whe Dorchester, the first named ame blackberry, introctuced by Mr. Lovett, of Massachusetts.

1850.-Cattle bred in Texas heing driven hrough Arkansas, Missouri and Kansas, for distribution and sale to feeders, causnd 2 mysterious and fatal disease amongst the native eattle First mention of fever caused by Texas cattle.

1850.-About this time a Mr. Goodrich introduced new wild strains of potators from South America, and, growing them for fifteen years, produced the Garnet.

1850. - Previous to this year practically "ll the eheese mole" in this country was a farm and not a factory product.

1850.-The Delaware-the fourth great Imerican grape-found in a New Jersey rarden. It enjoys the distinction of being the only one of the four which gives strong evidence uf "foreign blood," being considered between the fox-grape and a European vine.

1850, May 15th-Dispersion sale of Shorthorn eattle bred by T'homas Bates, deceased, at Kirklevington. Sixty-eight head weraged \$3.24.28.

1850, July 16th.-Millard Fillmore, elected Tice-President, succeeds to the Presidency of the United states, and serves nearly three years.

18.50.-Aruilla Young \& Everette, of lount Sterling. Ky., owned Imp. Mammoth, the largest inci imported up to that time.

1850. - Abel Houghton, of Massachusetts, 1) roduced the lougliton rooseberry from sees of the wild berry.

1850.-The mmount of butter made this vear on the farms of the United States was $: 13, ; 45,306$ pounds.

1850.-Ethan Allen, 2:25 1/2, famous trotling sire, foaled in this year.

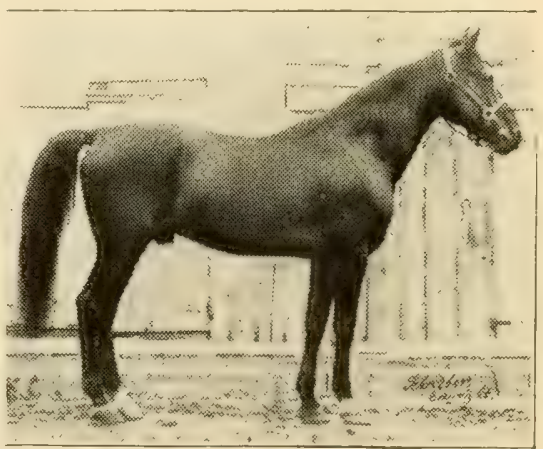

ETHAIN ALI,EN, 2:25 1/2.-The first stallion to beat 2:30. From a copyright photograph by lpemission of Schreiber \& Sons. of Philadelphit. This is one of the earliest high-class untouched animal photographs in existence. Although it is forty-six years old, Messrs. Schreiber \& Sons are still the leading photographers of domestic animals.

1850. - Importation of Spanish red hogs by Hon. James B. Clay, of hentucky. 
1850.-First steam engine for purpose of tillage placed on the market by John Fowler s'son, of Cornhill, London.

1850. - Wm. Chamberlin, of Duchess county, New York, imported 250 head of Silesian Merino sheep.

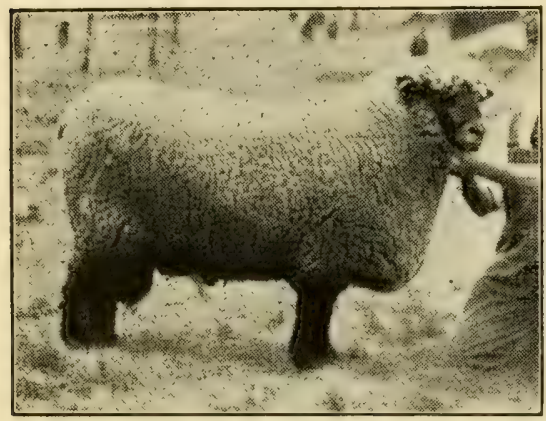

OXFORD DOWN RAM-A champion at the Iowa State Fair.

1850.-Oxford Down sheep coming into notice, principally in oxfordshire, Engand.

1850.--First recorded Galloway cattle im ported into Canada by Graham Bros., of Taughn, Ontario.

1850.-United States Census reported

$1,449,073$ farms in the United States.

1850.-The peppermint plant industry assumed its greatest proportions in England, declining since that year.

1850. Only three states reported over $20,000,000$ acres of farm land. Virginia, 26,152,311 acres; Georgia, 22,821,279 acres: and North Carolina, 20,9966,983 acres.

1850.-Center of number of farms in the United States, ten miles south of west of ]'arkershurg, W. Va., in Athens county, Ohio.

1850.-Center of United States population twenty-three miles southeast of Parkersburg, W. Va.

1850, Decemter 29th,-Commissioner J, JR. Bartlett, appointed to run the boundary line letween the United States and Mexico isitel the hacienda of Senor Won Manuel Candera in the province of Sonora. This ranch had 16,000 sheep, 700 mules, 108 stuci horses, 1,620 breeding mares and 6,600 calves. The farm produced 26,000 bushels of grain a year.

1851.-First public Agricuitural Experiment Station established at Moczern, Germany. under the atuspices of the University of Leipzig.

1851.-Mr. Lorillard Spencer, of New York, imported the Bates Duchess Shorthorn bull Duke of Athol, first bull of this family to arrive in the Uniter States.

18.51, January.-Here are a few items from an old New York market report in the American Agriculturist: White beans, $75 \mathrm{c}$. to $\$ 1.50$ per bushel; table butter, 15 to $25 \mathrm{c}$. per pounil; shipping butter, 9 to $15 \mathrm{c}$. cheese, 5 to to $10 \mathrm{c}$, per pound; cotton 12 to 1 fic per pound: wheat, Western, $\$ 1.00$ to $\$ 1.25$ per bushel; red and mixed wheat, $90:$ to $\$ 1.10$ per bushel; rye, 75 to $80 \mathrm{c}$; corn, Northern, 69 to $74 \mathrm{c}$; ; corn, Southern, 68 to $72 \mathrm{c}$ : : barley, 88 to $93 \mathrm{c}$; oats, 48 to $53 \mathrm{c}$. hay in bales, per 100 pounds, 70 to $175 \mathrm{c}$. mess beef per barrel, $\$ 7.00$ to $\$ 10.00$; beer, prime, per barrel. \$3.75 to $\$ 5.25$; smoked lieef, 6 to $12 \mathrm{c}$. per pound; rounds in pickle 4 to $6 \mathrm{c}$. per pound

1851. - Charles Fullington, of Union county, Ohio imported the famous French draft -tallion, Louis Napoleon, a short-legged. closely-ribbed, blocky and compact gray three years old. He was afterwards sold to A. P. Cushman, of DeWitt county, Illinois.

1851. - In this year Jacob Fussell, a milk dealer dellvering on four routes at Baltimore, Md., engaged in the wholesale ice cream business. In those days the little ice cream which was sold was by confectioners. They bought cream of him in an irregular way, and, as sweet cream was hard to keep oll hand, he began using up his surplus by manufacturing ice cream. He also did business in Wasinington, D. C., and in 1863 established the tirst wholesale ice cream istablishment in New York City Mr. Fussell was in active business for forty-five years, when his sons succeeded him.

1851.-A European grape successfully cullivated around Missions, in California, now known as the "Mission Grape."

1851.-In the American Agriculturist of February, 1851 an article appears entitled "Larke Cattle in Kentucky," by James G. Kinnaird, of Solitude, Fayette county. The fat cattle belonged to $\mathrm{Mr}$. C. W. Innes, of l*ayette, and won prizes for beef cattle. On exhibit, these steers weighed 2,710 and 2,740 pounds at five years old. The same exhibitor had thirty-nine head, averaging in weight from 2,000 to 2,435 pounds. $M r$. Innes also had a shorthorn bull which weighed 1,753 pounds. This was at the first Kentucky Faix, held at Lexington, Octoher IS50.

1851.-At Mount Fordham, New Yorls state, in the year 1851 , and the 24 th of June, a public sale was held by Mr. Morris, a Shorthorn cattle breeder. Colonel James M. Miller was the auctioneer, "who conlucter the sale with his usual ability and dispatch." The sale included bulls at $\$ 50$ to $\$ 175$, and females at $\$ 30$ to $\$ 175$. The inp-price bull was Logan, twenty-three months old sold to Oliver slate, Jr., of Throgs Neck, N. Y. The top-price female was the four-year-old Red Lady, sold to Ceneral Cadvallader, of Philadelphia. The sale was reported originally by the American Agriculturist.

1851. - A Mr. Wolfskill planted eights acres of apricots and peaches and 9,000 rrapes in the town of Winters, in Yolo county, California, in 1851. In 1885 the first apricots from these trees were sold. First commercial orchard of record on the Pacific coast.

1851--Reaping machines (McCormick's and Hussey's) first introduced in England from the United States.

1851.-Fire in Edinburgh, Scotland, destroved all pedigrees and papers relating to Galloway cattle.

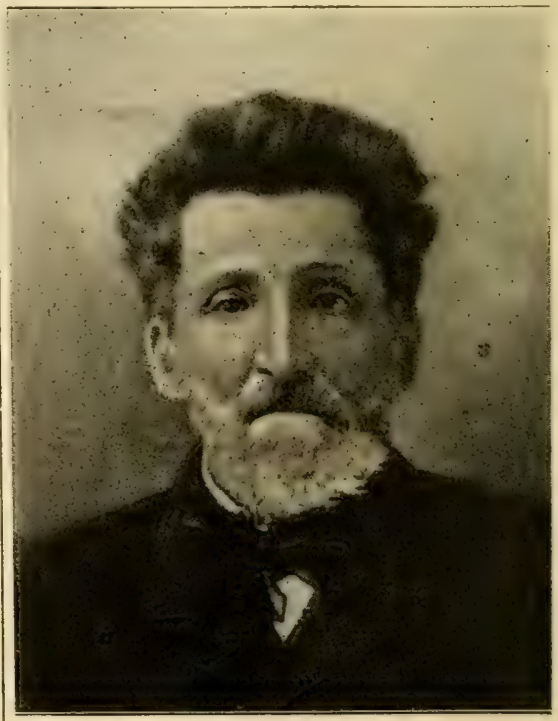

MR. W. H, SOTHAM, early Importer of Hereford cattle into the United States and a great advocate of the breed.

1851. - Exhibition of the Industry of All Nations at London; great help to agriculture. 
1851.- In this year racing was inaugurated in California. A small sehooner Asutralia, called the Sea Witch. Among her passengers was an Englishman named J Cooper Turner, who had with him twe hay stallions, a black mare and a gray Felding. The mare was called Black Swan, and she afterwards won a great race of six miles, ridden by Alexander Marshall, for a cattle (then worth about $\$ 4.00$ per head) hetween Ion Pio Pico and Don Jose hetween Don Pio Pico and Don Jose Siarco, who started favorite in the race. Black Swan led by seventy yards to the three-intle stake, where David $K$. Tidwell held a bucliet of water and sponged her mouth out. She was at least two hundred yards behind Sarco when her rider got her going again, but she won by over thirty lengths. The stallions of the importation were named Chloroform and Muley.

1851.-Captain J. T. Davy began the publication of a Devon Iferd Book, recording $\Delta$ merican yedigrees ten years farther than the oldest published for English herds.

1851. - First cheese fretory in the United States established in Oneida county, New york.

1851.-At the first International Exposition held at Hyde Park, London, in this vear, four prize medals were awarded to American sheep.

1851.-Messrs, Calloway \& Purkis, of England, with a view to improvement in steam culture, constructed a neat locomolive with two main traction wheels of eighteen inches tread with a truck forward for a steering apparatus.

1851.- American plows demonstrated their superiority over English plows at Hounslow England, during the first International Exposition.

185:- Mr. John Delafield, of Oaklands near Geneva. N. Y.. imported the first tilemaking machine for farm drainage.

185\%- - In January of this vear the Ohin Farmer was established at Cleveland, Ohio, by Thomas Brown.

1852. - irirst crop of "lemon yellow" to baceo produced on Sandy Ridge, in Caswell count:, North Carolnia.

185:-General trial of mowers and reapers at Geneva, N. Y.

185\%-Large importation of Andalusian iscks by Leonard Bros, of Mount 1.tonard, Mo.

185:-Reaying machine of home production invented by Rev. Patrick Bell, of Forfarshire, awarded premium by Highland Society. Had been in use fourteen years.

1852.-In the early summer of this year 'lom C. Ponting, ot' Moweaqua, Ill.. went to Texas on horseback and bought $\mathbf{8 0 0}$ steers there which he drove home and fed, the shipped them from Muncie. Ind. to New sork.

1852. - At this period, at the site of the present city of Fi Paso. Texas. there were ranches of Mr. Coon and Mr. Hugh Stevenson, and a small group of buildings called Magoftinsville, owned by James IV. McGoffin, a pioseer ranchman.

1853. April $15 \mathrm{th}$. - Through the action and rnergy of Mr. John Delafield, of Genevil, N. Y. an act was passed by the New York Legislature, establishing a state Igricultural college, which was opened seven years later end then closed down again.

1852. December 30 th. - A herd of wild mustangs stampeded the wagon train of Inited States Boundary Commissioner Bart lett in the vicinity of Loma Blanca, on the route to Corpus Christi, Texas. A few the horizon seemed to be moving with long undulations like the waves of the ocean The whole prairie was alive with mustangs. "h $\theta$ mules in the train became restive and the ceamsters hastened to pack the wagons, but one of the mule teams started the damede by springing from the horses. The avalanche of wild horses swept horsefi. The avala
1852.-The prairie dog was mentioned in John Russell Bartlett's Explorations and Inicdents in Texas: "One of the most interesting animals met with on the prairies and high table-lands is the praire dog. which in fact no other than a marmot, having no character in common with dogs. The first community was in Texas, near Brady's Creek, a branch of the Colorado of the East. This was the largest we ever saw, nor have we heard of one as extensive. The extent was ten miles in one direction and fifty in another. Fistimate was made of 30,000 habitations to the square mile, or 15,000 . 100 in all-a population of $30,000,000$ prairie dogs when figured at one pair to each habl ation or hillock.

185:, September 9th.-At Union Course. ong Island, an early pacer named Pet established a mile record of $2: 181 /$.

185*. - First trotting sulky without springs built for Flora Temple. The welght was about ninety pounds.

1853.-Prince, a horse of unknown breed in, trotterl ten miles in 28:081/2 minutes.

1853.--In the winter of this year a $\mathrm{Mr}$. Renick bought 1,200 cattle in Northern rexas and sold them in Illinois. This trade continued until it was exploded by the Texas cattie fever.

1853.-Belmont, a thoroughbred stallion bred by Carrett Williamson, of Springdale, near Cincinnati, and three mares were im porteu into California and left a lasting mark on the thoroughbred horse of Caliornit.

18.3.-Firanklin Pierce elected President of the Cnited states, and served four yeans.

1853.-Throush the Scupperning grape, a irect offspring of the Muscadine dis overed on Roanoke Islands, Sidney Waller of Brinkleyville, $N_{\text {. }}$ C., began extolling it in 1853 to the Commissioner of Patents as "he grape of grapes for the Scuth."

1853. - Uhe record for trotting one hundred miles was broken by Conqueror, a bay gelding by ta Tourette's Bellefounder, dan Lady McLain by imported Bellefounder. The time was eight hours, fifty-five minutes and five seconds.

1853, June 15th.-Highland Maid, a converted pacer, by Soltram, dam Roxana, She was piloted by $F^{*}$ J Nodine, of Centerille, N. Y.

1853, July - R. A. Alexander established a shorthorn breeding cattle herd at Woodburn, Ky. by generous importations of the cest of the breed.

1853, July 14.- Tacony trots in $2: 27$ on Union Course, L. I.

1853. - In this year a writer in the New York Herald said that four-fifths of the horses hauling the cars on the Sixth Avenu Railroad, New York, were from Vermont and New Hampshire, and nearly all of the celebrated Morgan breed.

18.5:3, September 27 th. Shorthorn cattle -ale at London, Ohio, by Madison County Importing Company. Average for twenty four cattle, $\$ 1,000$ per head, including elght wich sold for $\$ 1,000$ to $\$ 3,000$ each.

1853.- Kentucky sale of Shorthorns at the farm of B. J. Clay, in Bourbon county. $\$ 1,941.40$ each. Ten bulls sold from $\$ 1,000$ $\$ 6,000$ each

185.3.-Mr. Davis, of South Carolina, pur chased two head of Brahmin cattle from the English Earl of Derby, and brought them to the United States.

1853.--Captain Richard King established himself as a ranchman in Southern Texas and purchased 75,000 acres of land there by starting the Santa Gertrudes Ranch, in Nueces enunty.

1853.-At Royal Show Yard, Gloucestershire, England Shrooshire sheep were rec ognized as superior. Considered the turning point of the breed.

1853. - In this year special classes for Welsh cattle were first instituted at the English Royal Show.

1854. - The Tappahannock found in Virginia, the first variety of American wheat. 
1854, June, Cogs in driving wheels of mowers and reapers invented by James Buckingham, of Muskingum county, Ohio.

18.34. The Lasvton, or New Rochelle,blackberry was found on the roadside by Lawton at New Rochelle, $N$. $Y$., and was valuable and popular for many years.

1854, January 6th. The Country Gentleman established by $\mathbf{M r}$. Luther Tucker, of Thany, N. Y., under the editorship of Inther Tucker and John Jacob Thomas

1851. - The first authentic hybrid grapevin" vas exhibited hy John Fisk Allen-a hybrid hetween the Golden Chasselas and the Isabella.

1851.-First importation of Scotch-bred Shorthorns by the Shakers of Union City, Warren county, Ohio.

1854. - Michisan Southern Railway opened stock rards at corner of State and Twentysecond streets, Chicago, III

1854.-First importation of Shorthorn erttle into Wisconsin by Mr. John P. Roe of Waukesha county.

1854. $\rightarrow$ Royal Agricultural Society of England awarded silver medal to Mr. John Fowler's Draining Plow.

1854. -Dillon Bros, of Normal, Ill, pur chased one of the horses of the rrench importation of 1851 and won many prizes under the name of "Norman."

1855.-Mr. Wrm. Smith, of Woolston, Berlfordshire, England, used steam power in plowing; also a subsoiler of his own invention.

185̃.-Hamphire Hown sheep introduced into the United States, mainly in the South scattered and practically exterminated luring the war.

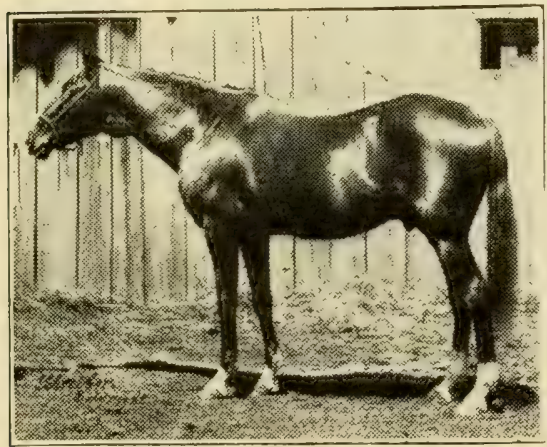

THOROUGHBRFD HORSE-IEXINGTON. From copyright photograph by Schreiber, diated 1372. He was the greatest race horso of his day and famous sire. He was then twenty-two years old, and died three years later.

1855, April $\angle d,-$ A great race between the thoroughbreds, four miles, Lexington reduces Lcompte's time of $7: 26$, establishing it record for the time of $7: 193 / 4$, which was unbeaten for many years.

185.5.-A conibined cover huller exhibited at the New York State Fair at Buffalo.

18.5.5.-A few Shropshire sheep imported from England into the state of Virginia.

1855.-Lewis F. Allen, of Black Rock, Y. Y. issued second volume of the Shorthorn Herd book.

1855.-Obed Hussey, of Baltimore, invented and put into operation a steam plow.

1855. - According to A. C. Landry, "the two successful pioneer oil mills of New Drleans were the Bienville, built and operated by Messrs. Pierre Paul Martin and Paul Aldige, and the Magazine Oil Mill, owned Poth of these mills were built and began coerations in the fall of 1855. There is a rivalry between these mills as to which was the actual pioneer, and the question was ever settled to the mutual satisfaction of the contending parties." By other authorities the Martin Mill was credited with having started in 1847 .

1855 - In a review of the Chicago live tock history by the Drovers' Journal, Mr. Ino. $T$. Alexander is mentioned as one of the createst cattle buyer ever on the ('hicago market. In this year he shippad , 000 head: in $11856,10,000$ head: in 1857 he shipped 15,000 head. Ife was a cattle raser in illinois and a speculator alsn. During that time he practically monopi. Jized the huying of cattle suitable from Eastern markets. With the principal railroad then running to New York Mr. Alexander made a contract to ship 1,000 cattlo a week, thereby securing a greatly reduced freight rate, which cattle raisers and other dealers could not touch. Mr. Alexander did not own a packing house, but he made larger amounts of money in rebates than re now considered to be fair backins ouse profits.

1855, June 11. - Snithfield, in London, market.

1855, June 21st.-At Union Course, Long Island, the mare Pocahontas established the macing record to wagon at $2: 171 / 2$. She was bred by John C. Dine, of Butler county, Ohio, by Iron'is Cadmus, he by Cadmus, son of American Eclipse.

185.5,-Colonel C. Is. Carter, pioneer Texas ranchman, settled in Palo Pinto county. He was afterwards one of the original organizers of the "round-up" system of gathering cattle, and President of the Northwest Texas Cattle Raisers' Association.

1855.-Col. Agoston Haraszthy introduced French srapevines into California after an extended European investigation.

1855, October:- At the Florence, Kentucky, Fair, Black Hawk, a Morgan stallion, exhibited by P. \& L. Melendy, of Hamilton county, Ohio, won the first prize in class for harness stallions four years old and up-

1855.- It was in this year when eattle iirst began to arrive at Chicago from Texas in droves. J. G, Law $\mathbb{E}$ Co, packed 3,000 head of them in 1559 , and other packers salted large numbers of them. The Civil Var temporarily stopped this trade.

185. - In this year Mr. Peter M. Gideon. f Minnesot $n$, began a series of discouraging experiments in order to discover an apple ree able to withstand tile severe winters of his section. In tivelve years he grew one seedling of the Cherry Crab, which prover hard. This was named "IVealthy," and upon this founstation the apple culture of the Northern Minmenota region has been built.

185.5. - The Royal Herd Book of Iereford attle it the Fleming Farm, Windsor, Engiand, was inunded in this year.

1856.- Charles Goodnight. Texas pioneer cattle roiser, arrived at the San Saba river with his partner and IV. J. Sheek, and came from tllinois.

1856. -George Wilkes, $2: 22$, a great sire of trotters, a famous son of Hambletonian, 10 , was foaled in this year. His dam was Dolly Spanker. He died in $18 \$ 2$.

1856.-Richard Ten Broeck sailed for Fngland with a stable of thoroughbredsfirst American to invade the English turf.

1856.-In this year the seed of the "hinese sugar cane, or sugar variety of the sorghum, was introduced into the United

1856. - The process of condensing milk invented by Gail Borden, of Galveston. Texas. He was horn at Norwich, N. Y., in 1802 and was the first white settler at Calveston. Texis.

1856. - First Parisian live stock exhibition under the patronage of the Emperor of English, Scoteh and Irish cattle.

1856. - I fis tree planted in this year is now one of the great hortjcultural curiosities of Californa. On Bidwell Ranch, 113. miles north of San Francisco. 
18.6. - In this year J. P. Anderson ensaged in catte raising in California, being one of the pioneers of the Pacific coast in that occupation. Forty-nine years later he shipped train consignments of his own cattle f
inarket.

1856.-Rev. Benjamin M. Nyce, "preacher, teacher and chemist," of Decatur county, Indiana, through insulation of l,uildings, developed an icestorage house, whlch is the origin of the moilern refrigerator. He stored fruts successfully for a rise in market prices.

18.36. -This year was noted for fuilure of crops in France.

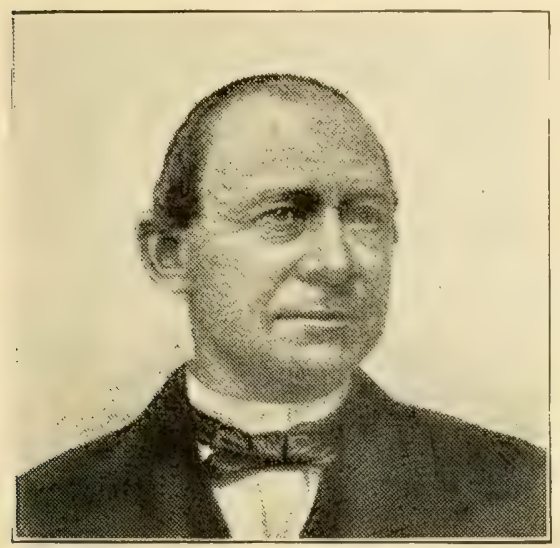

HTRAM WOODRUFF-Born, 1817; died, 1867. Famous as trainer and driver of trotters. He had the skill of the master, the affection of animals and the confidence of men. Picture from his book. "The Trotting Horse in America."

1856, Septenber 2d.-Flora Temple, by Fogus Hunter, dam by Terry Horse, trotted the Union course, Fast New York, in $2: 241 / 2$ she was driven by the renowned horseman. Hiram Woodruff.

18.56.-The Collynie herd of shorthorns. established by Mr. Wm. Duthie. Sr.. of Aberdeen, Scotland.

1856.-Lear Bros., of Kentucky, owned the large jack Buena Vista by jmported Mammotli.

1856--Colonel Richard Peters, of Atlanta, Ga., commenced breeding English Berkshire wine.

1856.-The inited States A Tricultural Society at Philodelphia awardeed Colonel Fichard Peters, of Atanta, Ga., a special fremium of $\$ 1,000$ on the Angora goats of the Davis importation.

18506.-American Aqriculturist, monthly farm paper. purchased by Mr. Orange Tudd. Alssociate editors, Rev. iv. Clift, M. C. Weld, Dr. Geo. Thurber, Joseoi Halstod.

1856.-In this year the first Angora goats received from Victoria, Australia, consisted of seven head, brought from Turkey by Mr. Sichel, a Melbourne merchant. These goats averaged a fleece of two pounds nine ounces when the Hock harl increased to los head.

1856.- First grafting of the prune at San Jose, Calif.

1856. - In his "Fruit and Fruit Trees of America," published this year, A. J. Down-

ing claimed that the Ameriean or Newtown idmittedly the finest apple in the world.

185ti. October 16th.-Opening of the Great St, Louis Fair, Original Directors: A. Harper, T. Grimsley, J. M. Chambers, J. R.

Parret, 11. T. Jlow, H. C. Hart, J. WVithnell,
T. 'Tanuary, $\&$ I. Ifunt, H. S'. Turner, F. bings and Norman J. Colman. Otticers were: T. R. Parrett, Fresident: A. Harper, $T$ ? Crimsley and H. 'T. Hart, Vice-Presidents: Norman J. Colman, Jecording Secretary Oscar Collet, Corresuondine Secretary; ani H. S. Turner. Treasurer.

185\%.-On February 9th, Congress passed bill providing for the construction of a wagon roal neross the country to the Pacific Ucean

185\%.- James Buchanan, I'resident of the Cnited states, and served four years.

185\%. The Cumberland Agricultural Society organized, becoming afterwards the Igricultural society of New South Waleg, Australia.

185\%. - In the "American Journal of science" Dis Gray showed that, although the pumpkin's origin was popularly sup poseri to he in the Ievant, there is good reason for believing it to have been cultivated in America by the Indians before the coming of the whites.

1857. -The United States War Department introduced camels into the country for use in the dry territories. Seventy-five were bought in Fgynt and Asia Minor by Major Charles Wayne. The naval transport Supply brought the eargo of camels. They were landed on the Texas coast, and under the care of Captain J. N. Palmer half of the herd was driven overland to Camp Verde. Ariz. and the others left at Indiancla. Texas. The campls did not thrive under treatment by Amerjcan teamsters, and. being neglected during the war, the experiment was a failure.

1857.-A gray horse named General Taylor, hy Morse Horse, dam Flora, un traced, trotted thirty miles in 147:59.

185\%.-Between this year and IS62 Mr. Winthrop IV. Chenery made three importa tions of pure-hred liolstein-Friesian cattle. 185\%.-Samuel Tyillam Johnson appointer? gricultural Chomist at Yale colleg. Author of famous popular works: "How I"lanis Grow," "How Plants Feed."

185\%.- The trotting record for three miles to wagon in a race was placed at $7: 531 /$ by Prince, a chestnut gelding, whose pedigree unknown.

1857, April.-Hereford Journal established OWego, N. Y., by W. H. Sotham.

185\%, May 13th.-At Lansing Mich., the itate Agricultural College was formally opened with sixty-one stundents and five professors, This is the first of the states to put in actual operation a true agricultural ollege.

1857. August 27th. Shorthorn cattle sale 1 springfiela, I11. Average for twenty even animals, $\$ 1,165$ per head.

18.7\%.-Mr. B. F. Harris, of Champaign, III. marketed a load of cattle at Clicago averaging 2.736 pounds, and the heaviest load ever sold on that market. These cattle were picked out of 100 head which $\mathbf{M r}$. Harris had fed to the remarkable average of 2,:77 pounds, Mr. Harris at this writing is alive and well. He is the champion feeder of heary cattle.

185\%, December 14th.-Mr. Morrell introtuced a bill in Congress providing for donations of land to states and territories which may provide agricultural colleges.

18.5\%.- In this year the Globe Sickle Faciory of Pittshurgh, Pa., was turning out sickles to greater value than all the other factories in the United States.

1857.-In this year, in the state of Mississippi, a law was passed requiring ever. cotton ginner to remove and destroy al! cotton seed. Failure was punishable by a fine of $\$ 20$ for every day in which he nes: lected to do so. Thus it appears that cotton seed was considered to be a nuisance, and itn accumulation thereof a danger to the community. Cotton seed was usually dumped into a stream of flowing water.

1858.-The first Argentine (South America) Rural Society organized through the efforts and advice of Don Eduardo Oliver a student in London. The first President was Gen Gervasio A Posadas was Gen. Gervasio A. Posadas. A mor 
1858. October 10th. At nine o'clock in the evening the first overland mail from California was delivered to the proper officlals in St. Louis, Mo.

1858. -Messrs. Gundlach \& Dressel, of Sonoma, Calif., imported choice varieties of French grapevines, especially from the Hhine provinces.

1858. - Nelson Morris commenced slaughtering operations at Twenty-first street Chicago-origin of one of the greatest packing houses in this country.

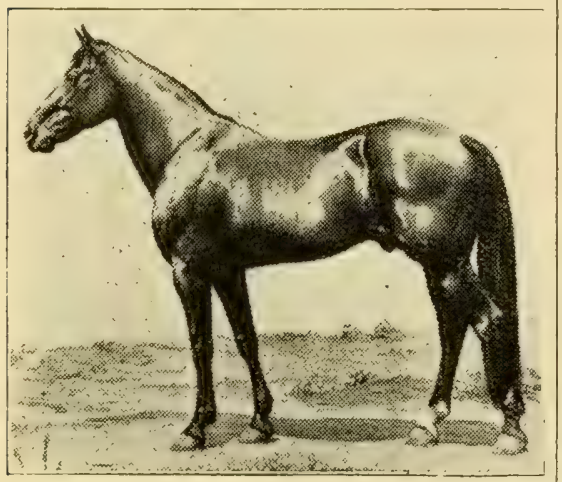

GEORGE WILKES, 2:22-Son of Hambletonian and sire of a distinguished family of trotters, whose name and fame are growing greater every day. From copyright picture by permission of Schreiber \& Sons.

1858. - In this year Thomas $H$. Burridge, of St. Louis, Mo., invented and built a traction steam engine intended chiefly for field culture.

1858. - J. S. Rarey, an American, first exhibited in London, England, taming vicious horses.

1858. Clydesdale stallion imported into Ohio by Fullerton \& Co.

1858.-Colonel Richard Peters, of Atlanta, Ga., imported Brahmin cattle.

1859, May.-Farmers Iprospecting on the plains of Nebraska, reported snow two feet deep.

1859. - In the month of April of this year the flrst issue of the Nebraska Farmer was published by Mr. R. W. Furmas. It was a monthly, sixteen-page, three-column paper, the columns being nine inches long. Mr. Furmas continued publication until April, 1862, when he exchanged the pen for the sword and went to the war. He was afterwards Governor of Nebraska, and at the time of his death w was Secretary of the State Board of Agriculture.

1859. A National Fair was held at Chicago in this year.

1859. $\rightarrow$ Mr. J. H. Pickrell, of Harristown, 111. first actively identified with Shorthorn (rattle interests. Afterwards Secretary of the American Shorthorn Herd Book.

1859.- Inmpshire Down sheep mentionad as probably a cross breed of Cotswolds and Leicesters by Royal Agricultural Society.

1859. Shropshire sheep arvarded a place on prize sheet of the Royal Agricultural Society of England.

1859.-Cotton shipments from Bombav, East Indies, to Europe and England, 622 319 bales. American crop same year, 4,861, 000 bales; total exports, $3,774,000$ bales.

1859.-Pleuro-pneumonia in cattle appeared in this country, being imported from Holland.

1859.-In September of this year tha Maryland Agrieultural College was formally opened.

1859, July 20th.-Fawkes' American Steam Plow, a gang of fourteen-inch prairie plows, was tried at Phlladelphia in this year. The mean rate of speed was four miles an hour and the united furrows were nine feet four inches wide. It plowed 4.3 acres an hour and was satisfactory to the committee and spectators.

1859 - The Farmers' High School of Pennsylvania (now the Pennsylvania State Col lege) opened for students in this year. Dr. Evan Pugh was the first President.

1859, October 15th-Flora Temple reduced the trotting record to $2: 193 / 4$ at Kalamazod Mich. She beat her own record three times in two months during this year under the guidance of James D. MeManus.

185\%. May 5th,-First shipment of cattle from St. Joseph, Mo., to Eastern markets.

1860. - The Tnited States Census Superinendent, in his introduction to the agricult ural division of his work, said: "We have two agricultural colleges in active operation and others in progress of organization. Our young men are beginning to realize that agriculture is worthy their highest ambition, and that in no other pursuit will in telligent labor meet with a surer reward."

1860.-Owing to the scouraging and exhaustive system of husbandry practiced in the United States, it was stated in the Mark lane Express of England that the grainaxporting mower of the United States was ikely to diminish rather than increase.

18100.-Goodenough's horseshoes, made by machinery, put on cold, patented in this year.

1860, September 27 th- Visit of the Prince of Wales, then heir to the British Throne, o the st. Louis Fair.

1860.-The Chautauqua grape industry began. In 1900 the Chautauqua grape bel contained 25,000 acres of vines, of which 85 per cent. were of the Concord variety.

1860.-Freat deposits of potash salts found near Strassfurt, Germany, which are now largely used for fertilizers.

1860.-Census of this year the first to report in detail the quantity and value ci commereial fertilizers manufactured in the nited States.

1860,-Lincoln sheep first given a class in English Agricultural Society.

1860.-Small Yorkshire swine introduced into the United States-a pure hog of English York and Cumberland breeds.

1860.-Paris green first used in Wastern States to kill potato bugs.

1860. - A grower of Garnet Chili potatoes preserved a seed ball of this /variety, pinning it against his window until it was old and dry, when he gave it to Mr. Albert Breese, of Vermont, who planted the seed and produced a number of good, bad and indifferent tubers and including one plant which surpassed all others. This was named the. Early Rose, which became the leading ariety in America.

1860. - In this harvest season four thousand-McCormick reapers were reported to have been sold to farmers around Chicago.

1860.-Flora Temple trotted three miles in harness, against time, in $7: 33 \%$. She was by Bogus Hunter, dam Madam Temple, by Terry Horse, and was one of the greatest time.

1860. First cotton mill in Texas built at Huntsville by the state government.

1860. - In the fall of this year the first New Tork Agricultural College was opened at Ovid under Presidency of Major M. IR. Patrick, but was closed again, owing to the breaking out of the Civil War, and was not opened again as a college.

1860.- In the year 1860 Illinois was seventh in the number of states as a porl and beef-packing center. California was first, with 199 houses; Pennsylvania second with 106: New York third, with 91: Ohin fourth. with 55: New Hampshire fifth, with 46: New. Jersey sixth, with 28; and Illinols seventh, with 22. Ten years later chicago alone had 31 packing houses, In 1850 Chicago had 70 packing houses.

1860, December 11th.-Parker Curle, Superintendent of a Louisville slaughtering house, with one set of hands, killed 2,171 hogs in one day. 
1860.-Ground broken at Kansas City for the Western Pacilic Railroad.

$1860, \cdots$ At the beginning of the sear 1860 the book entitled "Industrial Chicago" enumerates the beef packers as follows R. M. \& O. S. Hough established in 1850 Cragin \& Co. in 185t, Van Brunt \& Watrous in 185s; Gurdon S. Hubbard in 1834; Hayward, Rloomfleld \& Co. in $185 \mathrm{~s}$ : A. S Erown \& Co. in 1853; and Clybourne \& Co. in 1827. The hos packers were Jones Culbertson in 185s; Tobey \& Booth in $185 \%$ Leland \& Mixer in 1859: George Steel in 1843 ; C. \& J. Stewart in 1857 ; Thomns Nash in 1857; J. G. Law, succeeding Moore \& Seayerns, in $185 \mathrm{~s}$; Patrick Curtiss in 185

Burt \& Higgins in 1S5s: Itolder \& Priest in 1858; Louis Richber in 1858; Smith \& Son in 1858; Reynolds \& Lunt in 1857 ; Noyes . E. A. Kent \& Co. in 1860 . The first summer meat packing is credited to Tobey, Booth \& Co., and Van Brunt \& Watrous.

1860. - Bone black as clarifying or refining agent no longer used in sugar relining, being substituted by a sulphurous gas.

1860.- In this year five bushels of corm were raised in the United States for every single bushel of wheat. Illinois led the corn with 125,174,774 bushels: also the wheat with $23,837,023$ bushels.

1860.-Allen's Red Prolific and Allen's Antwerp raspberries introduced to tho public, heing improved surts of the English of Black Rock, N. Y

1860.-The census of this year says that the premium on goll increased the price of large margin was in favor of the Western wheat grower

1860.- No. 2 eash wheat ranged from 66 cents per bushel in December to $\$ 1.13$ in April.

1860.- The Department of Agriculturs introduced the Italian bee into this country.

1860. - Truck growers in Norfolk, Va., first to demonstrate that strawberries could be grown and ripened long in advance of the Northern crop. The industry failed because the crop spolled in transit, the

1860.-The United States Census reported $2,044,077$ farms in the United States, an increase of 595,004 in ten ycars.

1860. - Center of number of farms in the Inited States, forty miles northeast of Cincinnoati, in Clinton county, Ohio.

1860. - Center of United States population, twenty miles south of Chillicothe, Ohio.

1861.--Youatt (on the Horse) said: "The

Enolish (Shire) (Iraft borse sprung from Flemish blood.

1861.- Duchess Shorthorns exported to England by $1 \mathrm{r}$. Samuel Thorne, of New

Yorle state.

1861.-Early war prices of cotton: Highest price middling upland cotton, 35 rents; lowest of the year, $11 \frac{11}{2}$ cents.

1861. - Iow price of wheat: June and July, 55 cents; highest, in May, \$1.25.

1861.-Mr. Alfred I. Smith, improver of Suflolk horses, established a stud

Wondbridge, Suffolkshire, England.

1861.- Roval Agricultural Societ

Fngland awarded Mr. John Fowler $\$ 100$ for the most economical application of stean power to the cultivation of the isoll.

1861.-First creamery or butter factory in the United States started in Orange county, New York.

1861. - In the season of 1861-2 the distinction of being the leading packing point in the coluntry passed from Cincinnati to Chicago.

1861. - Of the small fruits the strawberry crop is more than all the rest. Average of the United States, 1,701 quarts per acre on 150,0110 acres.

18f1.- Jerry Eurnett, from Bates county Missouri, pioneer ranchman, settled in Denton county, 'Texas.

1861.-Abraham Iincoln, President of the United States, and served uncil April, 1865. when he was assassinated.
1861. - In this sear J, D. Ulrey and his partner, Wm. Veach, were conducting $a$ ive stock eommission business and stock cards it the corner of Irvin and North I'a, and practically cepresented all there was in the P'ittsburgh vack market.

1861.-I. Prevost, a Frenchman, began ill culture of the l'urilic Coant near San ose, Calif., an industry which did not suceed and was almost extinet by 1877 .

1861.-Thomas MeCrae, of Guelph, on ario, Canada, began breeding Galloway eattle and started successfully to prove the eat merits and high value of the breed

1861.- Modern herd of Aberdeen-Angus atile established at Ballindalloch, Seotlanu, y Sir George Maepherson Grant.

1861.-Mr. Wm. Landrum was awarded silver froblet and auction of the first goats (called Cashmeres the timel into California.

1861.-Atwood Merino sheep introduced into Ohio by Mr. Minortone, of Lewis

(enter.

1862.-Mr. Abram Fultz, of Pennsylvania cound some beautiful heads of smooth ariety which is known by his name.

1862.- On April sth of this year I. Winlow, of Hhiladelphia, obtained a patent for a new method of preserving green corn which ine assigned to J. W. Jones, of Portland, Me. This was the French process inventei Nicholas Appert, in 1795

1862, May 15th.-President Iincoln approved the bill establishing a Department of Agriculture, the Department being organized on July 1st of the same year. Hon. Isaac Newton, of Pennsylvania, was the st Commissioner.

186:- - In England, attention first drawn the probabilities and possibilities of heat hreeding.

1862.-Towest wheat, in January, 64 in

186i2. - First volume of Polled Herd Book, compiled by Mr. Edward Ravenscroft, of Galloway and Aberdeen-Angus cattle.

186\%, -Norfolk and Suffolk Red Polled cattle formally recognized in classes at the nternational show, Battersea Park, London.

1862,- Royal Agricultural Saciety of Englani, introduced special classes for Galloway cattle at International Show at Battersea, near London.

1862.-Gail Borden, of Texas, patented a process by means of which the juice of fruit, such as apples, currants and grapes, could be reduced to one-seventh of its orignal bulk.

1862. - The Massachusetts State Board of Agriculture held the first Farmers' Institute. 186:. - In this year C, Aultman \& Co., of Canton, Ohio, made 3,100 "Buckeye" mowng and reaping machines.

186:- The Free Homestead Law as wo understand it to-day was enacted this year and approved by President Lincoln.

1862, Marcli 5th.-Formation of the Kansas State Agricultural Society at Topeka. Officers: President, Lyman Scott, of Leavenworth: Secretary, F. G. Adams, of Shawnee; Treasurer, Isaac Garrison, of Shawnee.

186\%, July 2d.-Prassage of an act by the United States, apportioning lands for the establishment of State Agrieultural Colleges.

1863,-A. W. Hall, of St. Louis, Mo., took out a patent for a steam plow.

1863. - New York Central Stock Yards at Buffalo, N. Y., opened this year.

1863.- - In this year, at the Internation Exhibition at Hamburg. Germany, wher all. the finest flocks of Europe were rep. sented, two first-class prizes were awardel to lerino sheep from Vermont.

1863. - In this year Barbour Bros estah lished the first factory for making harness threads in this country. Previously all this product was imported from Ireland.

1863,-George M. Patchen, trotting under saddle, made the recora of two miles in $4: 56$. 
1863, January.-Isaac Newton, United Strtes Conmissioner of Agriculture, commenced analysis of vines, soils and grapes with a view to assisting the culture of the vine".

1863. - Lowest wheat, in August, s0 cents; hichest, in I)ecember, $\$ 1.121 / 2$

1863.-First 160-acre United States homestearl filed on by D. Freeman, five minutes after noon, near Beatrice, Neb.

1863,-In this year the Grand Prix de Paris was instituted, the horse Ranger being the first winner.

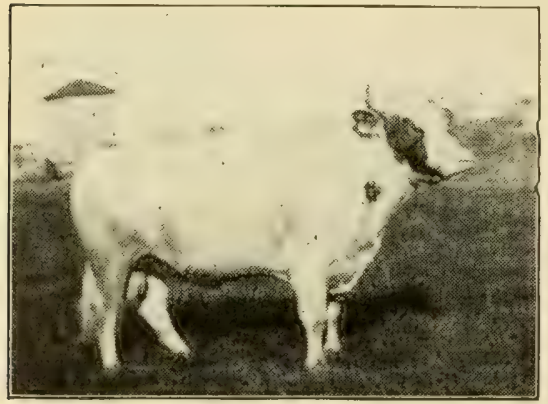

PRIDE OF AVON-AYRSHIRE BUIL. Champion at Detroit, 1911; champion and grand champion Grand Rapids, Mich.; also champion at Arizona Fair, Phoenix, 1910 and 1911. Exhibited by W. A. Macdonald Mesa. Arizona.

1863. - Ayrshire cattle breeders in America organized and begun the publication of a new herd look.

1863, February.-List of agricultural papers in the United States published by Norman i Colman in his Valley Farmer of this New England Farmer, Boston Cultivator, IIassachusetts Plowman, Hovey's Magazine of Horticulture, American Agriculturist, Workins Farmer, Horticulturist, Farmer and Gardener, The Gardeners" Monthly, Country Gentleman, Genesee Farmer, Ohio Farmer, Michigan Farmer, Prairie Farmer, llinois Farmer, Wisconsin Farmer, lowa Homestead, California Farmer and Canadian Agriculturist.

1863.- The American Devon Herd Book the first volume of a new serles, published in this year.

1864.- Ahout this time, in Warren county. Miscissiupi, Peeler cotton, the first longstaple upland variety, was introduced, by whom not known. The most widely-grown of Ions-tapled cotton in Mississippi and I.ouisiana.

1864. - Smaliest crop of cotton grown any time in the United States after it became a crop. The crop of $1864-5$ was about 250,000 bales. The Civil IV ar was responsible for the shortage.

1864.--Iighest wheat, in June, $\$ 2.26$ per husliel: lovest, in Mareh, $\$ 1,07$

1861.--High war prices of cotton: Highest frice of the vear. $\$ 1.90$ per pound; lowest, 7. cents. This for upland middling on the Now York market.

186.1. - Year of the birth of the "cigarette" mace from I'erigue tobaceo of Louisiana ind the bright yellow types of North Carolina and Virginia.

1864. - White Burley tobacco originated in Brown county, Ohio, from a sprout of the red Burley. Well adapted to plug filler: and plug ard twist wrappers.

1865.- Ixtract of meat, invention by Jiebig.

1845 - thout this time vegetable growing under glass began to attract wide-spread attention.

1865. February... Act passed in Kansas to prevent Texas stock being driven into the state on account of Southern fever.
1865. - Beginning of the spread of the peauut industry. Soldiers campaigning in East ern Virginia acquired knowledge of the piants and carried the seed over the south.

1865, February 13th--Special charter cranted hy the legislature of Illinois to the Union Stock. Yard and Transit Company of thicago, 111. Incorporators: John L. Hartgock. Virginius A. Turpin, Roselle M. Hough, Sidney 4. Kent, Charles M. Culbertson, Lyman Blair, Martin L. Sykes, Jr., George IV. Cass, James F. Joy, John F. Tracy, rimothy B. Plackstone, John H. Moore, bon S. Barry, Homer iv. Sargent, Burton C. Cook, John B. Drake, William D, Judson, David Kreigh, Joseph Sherwin and John B. Sherman.

1865. A plil 14th-Andresv Johnson elected lice-I'resiffent, succeeds to the Presidency of the United statos, and serves nearly four

1865. - National Wool Growers' Association reanized.

1865.-Captain McGowan, a roan horse of unknown breeding, established the twentymile trotling record of $58: 25$.

1865.-L. B. Silver, of Cleveland, Ohio, bought the follndation of his Ohio Improved Chester hors and commienced to build a train or family according to his idea.

1865.- - Auction of Shorthorn Grand Duchess eattle by catalogue at IVIlis' Rooms, Lonton, no animals being in sight. Thirteen eatile veraged $\$ 2,177.25$ per head.

1865. - The rinderpest, originating in Russia, reached London by importation of foreign catlle.

1865.-Dexter, by Hambletonian, 10th, dam by American Star, trotted two miles to vagon in a race in $4: 561 / 2$.

1865.-Lowest wheat, in December, 85 cents; highest, in Janury, $\$ 1.55$.

1865, December 25th.-Union Stock Yards, Chicago, Ill, thrown open for business.

1865.- "Gardening For 'rofit," by Peter Henderson, issued in this year-the first important work devoted exclusively to market garuening.

1865. - In this year the Turf, Field ant Farm was founded by S. D. Bruce, B. C. Bruce and Hamilton Busbey.

1865. - The territorial government of Montana passed an act concerning marks and brands at the request of cattle raisers then engaged in the lusiness.

1865. - J. M. Daugherty, famous driver of trail herds, engaged as cowboy for James Adams at San Antonio, Texas, He after wards delivered 40,000 Texas cattle in one year at govermment Indian agencies in the Northwest.

1865, July.-Birth of noted sow mentioned as being one of the best of the early I'oland Chimas - "Lady Pugh, white; one of the best sows in IVarren county, Ohio, Farrowed in July, 1865. Bred by J. B. Pugh, of Franklin, Warren county, Ohio, in the fall of 1868; owned by him until she died, August 29 th, 1876. Sired by Young Bob, 300; dam, the old Harkrader sow."

1865. - In this year the total recorded live stock receipts at St. Louis amounted to 94,$3 ; 0$ cattle, 99,663 hogs and 52,133 sheep.

1865. - About this time Paris green was first applied for the destruction of the potato nug and other leaf-destroying insects.

1866. - In this year a Colorado Cattle Growers' Association was partly organized; was completed in November of the year following with John Lilly, President; and J. S. Wheeler, Secretary. It was the year 1875 before colorado had an important cattle-growing interest.

1866.-First Belgian draft horse importation to this country by Dr. A. G. Van Hoorebeke, of Monmouth, Ill. Horses were called Boulonnais.

1866.-Henry L. DeVilmorin, a French plant breeder, found that 1,000 to 1,300 feet part was sufticient to prevent spontaneous intercrossing by wind-blown pollen. He was experimenting with Indian corn.

1866. - Ancona fowls first brought to public notice in the United States by the late Francis A: Mortimer. 
1866.-Practical Floriculture by Peter Ifenderson appeared this year; first important volume on the subject.

1866, January.-Mr. Luther 'Tucker, of Albany, N. Y.. publishing two farm papers, The Cultivator, by consoliclation with The Genesee Farmer, dating back to 1831 , and The country Genteman, founded in 1840 , combined the papers under the name of The Cultivator and Country Gentleman, the title being izbloviated to "The country Gentlemun" in $189 \mathrm{~s}$.

1866. - The fastest mile record trotting under saddle up to this period was made by lexter, the great son of Hambletonian, 10th, the time being $2: 18$.

1866. - In this year 262,000 head of Texas eattle were driven across the Red river into the Indian Territory and started for Sertalia, Mo., then the western terminus of the Missouri Pacific Railway; but local organizations of settlers barred the wav
and the drive ended in disaster and ruin to and the dri

1866.-After-the-war cotion prices: Upand middling, highest of the year at Nell York, 52 cents per pound; lowest, 32 cent:

1866,-- In this year Charles Goodnight, famous Texas ranchman. together with Oliver Loving, a native Texan, drove a herd of eattle from southern Texas up the Pecos river valley to Fort Sumner in order to fill a goverrment contract. At this period the trail was not established and no cattle were rancing between Horsehead Crossing and Fort sumner. In one of these trips Oiver Loving was killed by Indians.

1866.--.T. O. Sheldon, of Geneva, N. Y. hought all the available pure buchess shorthorns in America.

1866. -Dr. J. Stayman, of Leavenworth. Kas., grew a lot of apple seedlings, the seed being selected from a choice lot of Winesap apples grown in the county. He originated what is now known as the Sayman Winesap apple.

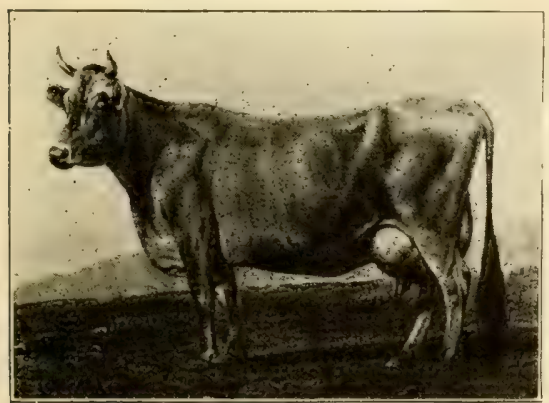

IDA OF' ST I AMBERT-Jersey cOW

18t6. - The Island Herd Book of Jersey Cattle-was started in this year. The first Cxamination for qualification was held on the 4 th of April. Forty-two bulls were registered as frunilation stock. Later 182 cows were examined and approved, and by the end of 1863 altogether 92 bulls and 381 cows and heifers had been examined. All these were qualified as foundation rows col. Le Conu wats

1866.- "Prince of Wales" foaled: most prominent Clydesdale sire, hred by James Nicol Fleming, of Ayrshire, Scotland: was sold at five vears old for $\$ 7,500$; sire of Alhion, 3,060-guinea colt.

1866.--I.owest wheat, in February, 77 cents; highest, $\$ 2.03$.

186\%.-The first United States patent for dise plow granted to M. A. \& I. M. Cravath of Bloomington, Ill.

186\%.-Bailey's Annals of Horticulture says that in this year the experiment of shipping green fruit hy express from Caliresults, as the excessive express rates, in connection with the fact that the fruit did not arrive in very rood condition made the experiment a losing one on the part of the shipuers.

1867.-.The Willet peach originated about this time from is peach stome brought by Cornelius O'firien, of Bryant's Minstrels from South America, and by him sown in his garclen at 110 Whest Fortieth street, Nett lork city. The property came into possession of $\mathbf{H} r$. Wallace $\mathrm{E}$. Willett when the tree was in full bearing. Twelve selecter specimens of the fruit of the original tree weighed twelve ounces each and measured twelve inches in circumference. It is de scribed in the Department of Agriculture $1867-M r$ Andrew Aibright of New Jersey, patented a process for the introduc tion of hard rubber covered harness trimmings, a purely American invention, which has figured conspicuously as a mounting for

186i7.-Gerritt $S$. and Dudley Miller, of New Fork, imported IIolstein-liriesian cattle from the hest herds in Holland.

1865\%.-First selection of Griltin cotton produced by John Griftin, Refuge Plantation. Greenville, Miss. One of the best lonstaple upland cottons.

1867.-At the Paris Exposition, a Poitou iack sold for $\$ 3,200$, to go to South America.

1867. The Englinh Derby was won by Hermit, a horse owned by Mr. H. Chaplin. There were thirty starters, and the time was 2:5\%. A horse called Marksman was

186\%_-A pear tree planted by Governor Peter Stuyvesant at the corner of Thirteenth street and Third avenue, New York, was destroyed in this year, after having attained to more than zuo years of age.

186\%, July 30th-Dexter, the first great son of Hambletonian, 10th, dam Clara, by American Star. made his famous trotting reeorl af $2: 1 y$ at Riverside Park, Boston, Mass. The track was a half-mile one, and he was driven by the celebrateed Budd Doble.

1867, November 26th.-First patent for refrigerator car taken out by J. B. Sutherland, of Detrolt, Mich.

1867.-American shorthorn eattle sold at the Queen's farm, Wrindsor, consigned by Non 615.50 per head. These cattle were sold by candle light.

1867.-C. W. Chenery, of Massachusetts mported Angora goats.

1867. -S. T. Todd, son of the originator of the Tout hog, began crossing with pure Whester Whites; origin of the $\mathbf{0}$. I. C. Improved liog.

$186 \%$ - Mr Israel S. Diehl commissioned 1.y the United States Agricultural Depart ment, isited the province of Angora to investigate the mohair inlustry.

186ir.--In this year a cattle trail was established, extending 1,200 miles from Corpus Christi, Texas, 10 Ailene, Kansas, mainly through the exertions of James G. Mccoy. This trail lasted without change for four years, and the northern terminus was afterwards changed several times. notably to Wichita and Dodge City. In twenty years $9,999,970$ head of cattle passed crer the trail, which finally extended by way of Ogallala, Nebraska, to the British yossessiuns.

186\%.-A. C. Frankin and Major Tul Craig. of Sumner county. Tennessee, made a large importation of Catalonian , jacks, first importation after the war.

1867, August 14 th. - The famous Dexter reduces the mile trotting record to $2: 171 / 4$ at Buffalo, N. Y.

$186 \%$. - First of many Shorthorn cattle importations by Fion. M. H. Cochrane, of Hillinurst, Quebec, Canada.

1867.-Frahmin eattle introduced into Mexico. F: McManus \& Sons shipped twenty head (from the Davis importation) to a farm near the City of Mexico.

$186 \%$.- Lowest wheat, in August, \$1.55; highest, \$2.\$5, in May. 
1868. - Mr. James Duncan, sugar refiner, of Mincing Lane, Iondon, erected first beetsugar factory in England at Lavenham, in Suffolk.

1868.-Mr. Parlier Farle, of Cobden. Ill.. successfully transported strawberries to Chicago, New York and New Orleans in lefrigerator cars.

1868.-John H. Potts \& Son. of Jacksonville, Ill., commenced breeding Shorthorn cattle which developed into a great show herd.

1868.- IBef eattle were driven out of Montana Territory by D. Hogan, of Augusta, in the interest of a firm named Orenstein \& Pouper of Salt Lake City, and bought from a range cattle owner named $P$. I Jargey.

1868. - The dirst I'ercheron horse importation west of the Wabash made by W. J. Edwards, of Chicago. He imported two great itallions called Success and French Emperor.

1868.- The seedless apple reported to the New York Farmers' Club as having beem found in West Virginia.

1868.-Longfellow, a chestnut gelding by Ped Bill, paced three niles to wagon in a

1868.- Iowent wheat, in November, $\$ 1.041 \%$ : highest, in July, $\$ 2.24$

1868. On tile 11 th of July, 1868 , Major $11 \mathrm{~m}$. Noble Davis, of Kendali county, Iliihois. bought 181 head of Texas cattle at the Chicago Union Stock Yards as feeders for $\$ 20$ per hear. He paid $\$ 550$ damages for introducing Texas fever to the cattle of walker whu was one of his neighbors.

1868.-In the spring of this year, A. C. and IV. L. Cassidy, together with D, Sam Irons and Johis 'T', Berry, formed a partnership in the lize stork commission business at the Froadway Stock Yards, St. Louis, Mo. Others engaging in the business about the came time were J. I. \& R. F. McCormack, Buchanan \& Hurley and Tom Gregory. All vere pioneers in the live stock commission husiness.

1868.-Sir .T. Hawley's Blue Gown, sired hy Beadinan, won the English Derby in the remarkably fast time for that period of $43 \mathrm{j}$. Eichteen horses started,

lfred licing the second.

1868.--The lirst person who engaged in Dacling pork at Kansas City was Thomas J. Piger, in the fall of 1869. Mr. Bigger encaged exclusively in preparing meats for hipment to Belfast, Ireland

1868. - The twelfth census of the United tates says that the most important step in the development of American beef as an "rticle of commerce was the invention of the refrigerator car by William Davis, of Detroit. The patents were issued in $186 \mathrm{~S}$, ind in september, 1869 , the first cargo of rresh beef wats shipped from Chicago to Boston. This was the commencement of a reat industry in the United States and the initial step toward the roreign trade. The ars now useal by the great meat packers "if the West are founded on the Davis patent of 1868 .

1868. - The Chicago house of Armour \& Co. hegan making hogs in 1868. The beef packing was of later origin. Armour, Plankingten \& Co, had previously organized in 1.563 at Milwaukee. In 1870 they absorbed a large portion of the pork-packing interests of Chicazo. The Kansas City house vas established in 1871 .

18f8. - Annals ot Forticulture by Bailey says that in the month of November, $186 \mathrm{~s}$, $N$. B. Doe, at that time located on Vesey Pier. New Yurk. received one car of California grapes and three cars of pears. The yrapes consisted of several varieties, bux mostly Tokars, and arrived in good condition, selling from $\$ 10$ to $\$ 15$ per crate of forty pounds net. These grapes came through by passenger train in a ventilated car. with freiglt charges of $\$ 1,200$. The pears were winter Nells and Easter Buerre and arrived in very good condition. They realized from $\$ 3.50$ tin $\$ 5.00$ per box." The pears came by freight train in ventilated cars and were in transit twenty days, freight on same being $\$ 609$ per car. The result of the shipment aftorded sufficient encouragement for shippers to continue with consignments.

1868.- - In the year $186 \mathrm{~s} \mathrm{Mr}$. P. Hutchinson oought ground adjoining the Unjon Stock rards, Chicagro, and immediately proceeded to huild a Jarge parking house upon it. This is the leading item in the conceniration of packing houses in tive icinity of the stock yards.

1868. - The perpetual flowering carnations first imported into America, and growitl thein under glass was commenced.

1868.-D. Hogan drove a herd of beef cattle from Montana for the purpose of filling contracts along the Union Pacilic liailroad. 'The contractors were Orenstein \& Eof.jer, of Salt Iake City, and the cattle were purchased by $\mathrm{P}$. Largey.

1868. Checsemaking reported as being an important industry at Centralia, Nemalia county. Kansas.

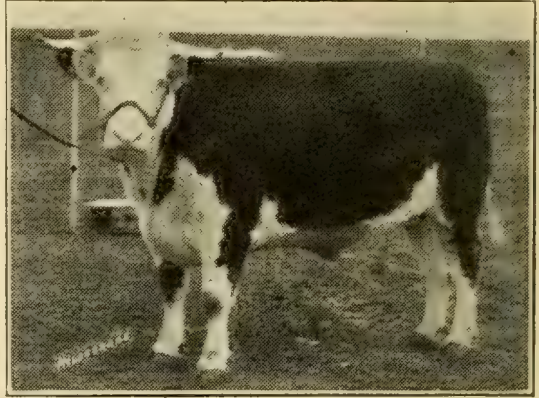

CLIFTON - CHAMPION HEREFORD STEER AT THE CHICAGO INTERNATIONAL LIVE STOCK EXPOSITION, 1911. Exhibited by J. P. Cudahy, Kansas City, Mo.

1868. - In this year a four-year-old Hereford ox vas winner of the gold medal as the best ox or steer of any breed. This at the show of the smithfield club in Londun.

1869. - The English Derby was won by Pretender, a horse owned by. Mr. J. Johnstone. The time was $2: 521 / 3$, and Pero somer was second.

Is6\%.-Fxperments of F. A. Carriere wiun the wild radish form a classical example of plant brecling. In five years by means of cultivation and celection alone he producri from it troublesome veed practically all the 5pe forms of radish ir: cultivation.

1869,---In. this year only four varieties $n$ swept corn were to be found in the seed

1869.-Longfellow made the record for four miles paced in harness in a race, the time being $10: 34 \%$. Longfellow was sired by Reat Bill, but his dam is unknown.

1369.-Dr. IN. Nobbe, in 'Tharand, Saxony. legan testing seeds, and was the beginning of extensive seed central work in Europe.

1869.--The fasteat record for four miles trotted in harness in a race was made hy Lady Dooley, a brown mare by Black Hawk. The tinc for the distance was 11:05.

1869.-Iriysses \&. Grant elected I'resident of the Tnited sitates, and served eight years.

1869. - A native of Angora, in Asia Minor, A. Iutvehides, bruight 175 Angora goats tis this country.

1869.- - A writer in the Agricultural Journal of the Cape of Good Hope says: "A feature worthy of nole is that Bredasdorn opene. the new industry of ostrich farming, as in the spring oi 1 sig the first lot of chiciss were domesticated with remarkable success on the farm of Zoetendal's Vallei, where the Ivild ostrich was to be seen stalking the lowns in large flocks. It was of these birds, twenty-one in all, of which one of the Dulse of Edinhurgh's party shot one by mistal: $\theta$ near the yard, taking them for wild birds, after the Duke had bagged a fine wild cock not far off." 
1869. Downing"s "Iruits and Fruit Trees of America," published this year, mentions more than $1: 6$ varieties of peaches in thi country, a!so 970 rarieties of pears.

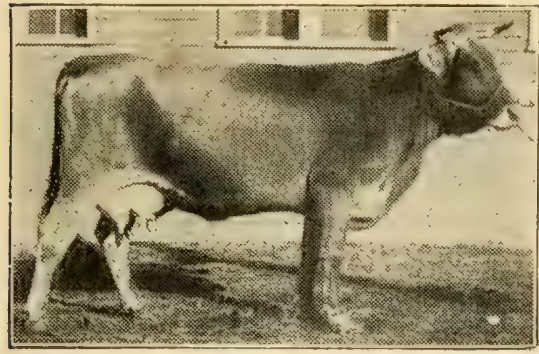

MCAIPINF-Champion Brown Swiss cow at the Illinois State Fair, 190 b. Owned and exhibited by $\xi_{s}$. M. Barton, of Hinsdale, III.

13h4.--In the autumn of this year one bull and seven heifers received in Massachusetts of the lisrown swist herd represent th

1869.--The first commereial orchard the Southwest planted five miles west of sipringfield, Mo., by Hon. Ira $s$. Haseltine it consisted then of ninety acres, and in creased until 2,000 acres or more of apple crchards were plantei by this family.

1869. - The disease first called dikkop, laler known as wire worm, developed to an alarming extent sinongst sheep and goats in South Africa, killing eighty to ninety oer cent. of lamks and kicls.

1869. - A count of cheese factories showed 1.000 or more to be nwernted in the United States.

1869. - James 'T', Worthington published a "Manual of Fir Culture in the Northern and Middle states. It was issued at Chill: cothe cinio.

18199. - On December $15 \mathrm{th}$ the Kansas Cit

Ponulogieal cociuty was incorporated, the

tirst presilent beine IVilliam Tanner of veswenworth This was changed later

the Kousa state Horticultural Society.

1860. May. -Mr. J. H. Sanders began the pubifation of the monthly Western Stock Journal i-sued at Sigourney, Iowa, afterwarls consoljdated with the National Live Stove Jowrmat.

1869-Diehl \& Brown of Ohio, imported 335 Angora suats.

1869--Extensive markets and abatoirs of 1 , it Vilette, concentrating the seven live stock inarkets near Faris, France, were opened in th?s year.

1819.-Jondon Smithield Club heef eattle clampions for previous thirty-three years ilere as follows: Shorthorns, fourteen times: iverdeen-A r $u=$ rime. Crosses, four: Devons, ihree: and Hereiords, three.

1864.-Ilighest wheat, in August, $\$ 1.46$; iowest, in December, $76,1 / 6$ cents,

1869. September. - I successful shipment of dresiced beef to boston in a refrigerator car made by D. W. Laris of Detroit, Mich. sald to be the besinning of the dressed-ben industry.

1870.- In this year was the first recorded export of cotton-ased oil, amouliting to 414,946 in value. This increased to $\$ 2,514$, in $\vdots 278$

18:0. - The Superintendent of the Unitod sitates Census of this year mentions corn selling at 90 cents a bushel in New England, and being burned for fuel in Iowa: wheat celling at $\$ 1.35$ per hushol in New. York and 15 cents in Minnesota: beef bringing $\$ 7.00$ yer hunilred on the hoof in the East and at the same time cattle being slaughtered for their hides in Texas.

1870.- In this vear a large cargo of live cattle was exported from a Southern Texas port to Glasgow, Scotland, and only 15 per cent. arrived. These shipments became more regular afterwards, but the shipping ex- penses were advanced to $\$ 48.66$ per heal and the trade was closed on that ascount.

1870.-Mr. Enverson, of Mountain View, anta Clara county, introduced pure-bred IIolstein cattle into the state of Callformia. 1870.-I.ord F'tulrnouth won the English Berhy witl kingeraft, by King Tom, in $2: 45$. F'almerton was second in a field of fifteen stirters.

18\%0.-In this year oleomargarine was inented by a Frenchman named Megemouries. 18\%0.-The first Jabanese olum to grow in this country, the Kelsey, was introduced in his yeat

187(). John Reher, of Lancaster, Ohio, befan the work of importing Clydesdale horses into the IInited Sitites.

18\%0.-United States Census reported 2.659,9\$5 furms in the United states, an in. crease of 615,908 farms in ten years.

1870.-Genrge Waring, farmer and sanitary engineer, introduced the Trophy comato, the result of twenty-three years' areful selection.

18\%0.-Clark \& Green, of Jefferson county, New York, made an exhibit of Cheshirs wine at the St. Louis Fair, and won $\$ 500$ affered by pork nackers for the best heral cor packers' use

1870. Bolgian draft horses imported by Massion son, of Minonk, Ill.

18\%0.-Hrown swiss cattle first imported H. M. Clarke, of IBelmont. Mass.

1870.-More than 80 per cent of the sheap in the United States were of Merisin

1870. June sth,-Daniel McMillan kale of Shorthorns at Xenia. Ohio. Seventy-four cattle averared $\$ \$ 64.60$ per head.

18\%0.-First large prune orchard planted at San .lose, Calif.

1870.-William Deering, of the state of Maine, arrived in Chicago, and with. $J$. D. Easter as partner established the great agricultural implement factory which now bears his name, manufacturing the Marsh Harvester and the Whittington WVire Binder.

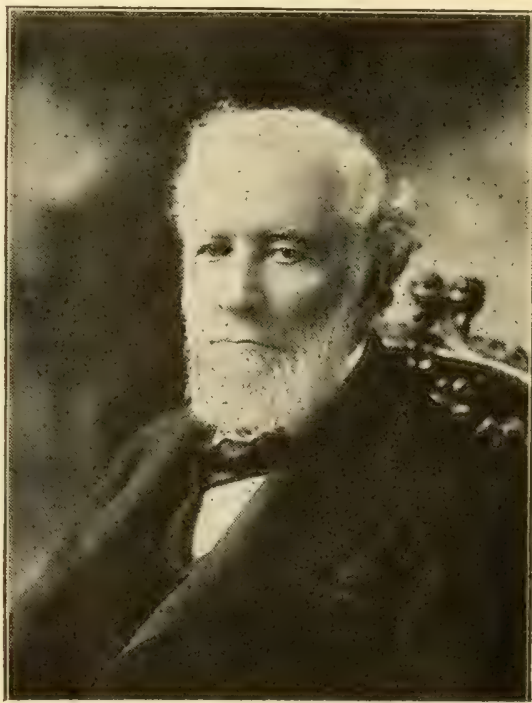

MR WILLIAM DEERING, one of the founders of the farm-machine industry and for many years a great manufacturer. Born April, 1826, at South Paris, Maine; died December, 1913 .

18\%0.--One of the greatest show yari contest in history-Shorthorns at the St. Louis Fair. Colonel Wm. \&. King, of Minneapolis. Minn winner of the herd prize defeating Illinois, Missouri and Kentucky. 
1870. The census of this year shows the wcet potato crop of the United States to be $21,709,824$ bushels-Vermont producing only

1870 -Center of the number of farms in the United States, thirty-one miles eastnortheast of Cincinnati, in Brown county. Ohio.

18:0.-Introduction of "new process" of reducing wheat to flour at Minneapolis, wheat section of the Northwestern States to settlement.

18\%0.-The Union Colony settled areeley, Colo. beran irrigating.

18\%0. November 1st.-First systematical veather bulletin issued by the United States Signal Service. Twenty-four stations reported.

1870.-Gen. Charles P. Stone, an American serving in the army of the Khedive of Esgypt, sent shoots of the Date l'alm to Southern California.

1870.--In this year Nutwood, 23:18 $3 / 4$, was fonled at Woodburn Farm, Ky. He was a noted sire of mandard speed and Ereatly Ianuary, 1906 , his daughters had produced 268 performers with records in standard time, of which number 200 were trotters, No other stallion has nearly so food recuril.

18\%0. Center of United States population, forty-eight

1870, November 17 th.-First bect-sugar factory in California opened on the farm of F F. Dyer, of Alvarado, Alameda county, hy the California Beet Sugar Company. The stockholders were: C. I. Hutchinson, Flint, Bixby \& Co., T. G. Phelps, E. H. Dyer, E. R. Carpenter, E. F. Dyer, W. B. Carr, W. T. Garratt, F. G. Rolins, all of California, and A. D. T3onesteel, A Gtto and Ewald Klinean, of WVisconsin.

1870.-Lowest wheat, in April, $73 \frac{1}{1}$ cents highest, in July, $\$ 1.311$

18:1.-Baron Rothschild's horse, Favorius, caytured the Emglish Derby, Albert Victor and King of the Forest runing a dead heat for second place. Time, $2: 50$.

1871.-Creat year of the Texas cattle drives to Kansis, Colorado, Nebraska, Wy oming and Montana. About 600,000 cattle went north on the various trails.

1871.-The National Live Stock. Journal of Tanuary, 1s71, cuntains a write-up from puchess Farmer of the largest emporium for live stork but one in the United States. l'his emporium was owned hy the New Yorlk Central and Hudson River Railroad at West Albany, N. Y. The yards were constructed in accommodite 8,000 cattle and 10,200 sheep. 'The peris for hogs contained 1,141,nกी square feet. The article concludes by saying that 3,000 cattle are often sold, weiched, paid for and shipped within the space of three and one-half hours.

1871.-At the Weehawken (N. J.) Stock Yards, way back in the past, they charged forty cents vavdage on Texas cattle. newspaper calied the Globe said in January, 1871. .Those cattle from Texas have wide spreading liorns and look lean and lank It would be impossible to fatten such creatures or cut a tender steak from them." This item was discovered in an investigation of the cattle irarle of the Lnited States, and is an example of old-time conditions. Texas cattle were shipped all the way from the range country to Weehawken, N. J., and were sinrunk of their fat in transit anil eaten up by expenses. This accounts for the immense number of beef cattle that net their owners liut $\$ 10$ per head on the home ranges.

1871.-Lowest wheat, in August, $92 \frac{1}{2}$ cents: highest, in February, April and sep tember, \$1.32.

1871, December 28th.-Formal opening of the foreign cattle market at Deptford, near tondon England mainly for receipt of cattle from the continent of Europe.

18\%1.-Golden Eagle, one of the eigint races of corn, recognized by the Illinois Corn Breeders Association, originated this year with H. B. Perry, of Toulon, Ill.
18.71. - The American Trotting Register tarted by J. 11. Wallace in New York.

18\%1, June 1st. -The first opening of the Kansas City stock Yards as a live stock narket. First President, James F, Joy; Superintendent, J. G. Smith; Secretary and 'Treasurer, Geo. N. Altman. Receipts for' seven months of 1871 were 120,827 cattle, 41,036 hogs, 4,527 sheep and 809 horses and ules.

18\%1. - In April of this year the National Live Stock Journal of Chicago contained an tem which conmences by saying that Texas has 500,000 inhabitants and $2,000,000$ head of caitle. It mentions the ranch of Col. Richard Iing, who owned 65,111 cattle, 10,006 horses, etc. The article concludes by saying: "A steer is worth about $\$ 10$ in Texas."

1871. - "Billy Atlanta," famous Angora male, killed by accident, at ten years old was sire o1 $3000 \mathrm{kids}$, and was sweepstakes winner during his entire life. Owned by IVm. Landrum, of San Joaquin county, California.

18\%1, Septemler.-National Live stock Journal established at Chicago by John $P$. Reynolds and George P. Rust.

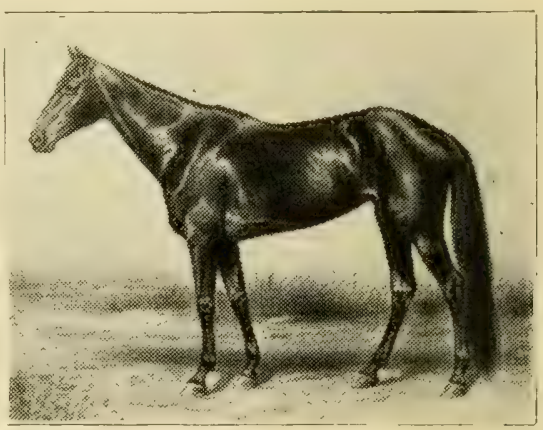

GOLIOSMTTH'S MAIU.

18:1, September fith.-.Goldsmith's Maid placed the trotting record at $2: 17$ at Milwaukee, Wis., driven by Budd Doble. She vas sired by Abdallah, 15, her dam Ab, by lbrlallah, 1

187\%.-In a book entitled "One Hundred Years of American Commerce," by Hon. Chauncey M. Depew, a chapter by Philip D. Armour mentions this year as the first of consequence in summer pork packing, there being 505000 hogs packed in the summer season of that vear.

1979. In this vear the first commercial rganization of packers of canned goods met in convention in Philadelphia.

187: June 9th-In a race against time, Goldsmith's Maid reduced the world's trotting record to $2: 16^{3 / 4}$

187:--In November of this year the first north-hound shipments of Texas beef cattle were shipped from Denison to the Chicaso market. The route was by the M., K. \& T. Railway to Hannibal, thence to Chicago. The first shimment consisted of fifty-five cars, thr principal shipper being Jerry Ellis, of San intonio Mr. John G Taylor represented the railroad interest as live stock gent of the M. K.\& T, and C. B. \& $Q$ Systems.

1872. From this year dates the cattleranching period in what is called the Pecos viver country in Texas. John Chisum. pioneer ranchman, and the only one distincuished by having a trail named after him, was the one cowman known to ranching on the Pecos at that time.

18\%*-'The National Swine Breeders' Convention mentions one family of pigs, known as Virtorias, originated with Colonel Frank v. Curtis, of Kirby Homestead, Chariton, Saratoga county, N. Y., referred to as Curtis Victorias. Descended from a sow called Queen Victoria 
1872,--Olive oil first made in California at Santa Barbara.

187:- Ipoland-China swine oflicially adolted by the National Swine I3reeders' Convention.

1872. - Iin the second successive time

horse sired by Harnesan won the Englisi Derlyy. This year it was Cremorne, the property of a Mr. Saville. The time was 2:45 i2. Pell Mell came in second.

18\%:-National Swine Breelers" Convention mentioned description of Neapolitan log, a few being in this courity

1872. September 5th.-Earl Dunmore's cattie, forty-eight shorthorms, sold at an average of $\$ 1,250$ per head.

187\%- National Sivine Breelers' Convention mentions description of American suffolk swine.

18\%2, Novemiver 17 th.-Permanent National organization of Ameriean Shorthorn Breelirs. First ofticials elected: President, Dr. A. C. Stevenson, of Greencastle, Ind.: VicePresidents, Wm. Warfield, of Lexington, Ky. and Hon. David Christy, of Paris, Canada: Treasurer. John G. Dunn, of London, Ohin: Secretary, B. H. Camplell, of Batavia, Ill.

187\%.-Flgin 13oarl of Trade organized. Fstablishes weekly butter quotations in the istgin district and has great influence in regulating the price of butter production in the United States.

1872. Mr. P. M. Iar.Price introduced a valuable greenish-yellow sugar enue into I.ouisiana tron the Eastern hemisphere.

18\%2.-Lowent wheat, in November, $\$ 1.01$ highest, in August, $\$ 1.61$.

1873, January.-Daily Drovers' Journal founded at the Chicafo Union Stock Yards by Harvey i. Goodall.

1873. - In this year Florida oranges began to arrive at the New York Produce Market, some of the eamliest arrivals being consigned to Walter Carr \& Co. For severa years the price of these fine oranges was $\$ 6.00$ per box. In the beginning it is sair that a larga number of irresponsible dealers obtained consicnments of oranges for which they made no returns. A book entitled "Annals of Horticulture" says: "It is uncioubtedy true that the fruit growers wero swindled right and left, so that it is no wonder they looked about for a remedy, and soon afier the Florida rruit Exchange (now the greatest frut organization in the world) entered

18\%3.-In this year a shimment of dresserl beel was made from Denison Texas, to New Yorls city. 'I'he parties so the experiment tvere John G. Taylor, Iive Stock Agent M. K. \& 'T. Railway; John Bates \& Bro., bankers, 5" Wall street, New York; George H. Rankin, owner of an ice machine at packer, of Haminond, Ind. Four loads of cattle bought by Mr. Taylor were slaughtered by a huccher named Quinn and placed in refrigerator cars, which were imperfeet in construction. Althoigh the train was delayed and behind a wreck at Parsons, Kas., and wert to New York via Chicago, the meat arriced in good condition. Defective cars and poor icing communications interfered with later shipments, and the death of Mr. Join Bates put an end to the experiment.

18\%3. "In this year the railroad companies of the United States demanded payment in lind for the carriage of com, and it appears exacted in some cases as much as two statement was made in the Republic Francalse, a Hrench paper, then reviewing calse, a French paper, then reviewing American agriculture, and said: "Owing to farmis, the grangers of the Far West will soon exhaust the soil, and the exaggerated production of corn in the Far West will not last forever.'

1873.--In this year the St. Louis Slaughtering and Rendering Company opened up for business. It was located opposite the Iioad. Mr. Joseyh Mulhall was President, and the capital stock was $\$ 500,000$. Before the days of cold storage and refrigeration this was onc of the rrentest Westery aughtering plant.

1873.- In this year M. Coffart successfully kept maize ath (msilage. He is generally retited with being the originator of the

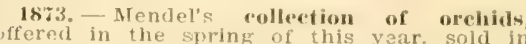
England as high as $f 20,\{40$, and one ylant f5y $17 \mathrm{~s}$, the returns for the whole eollection being $\ell 4,361$.

1873.-Henry Evans. Jr., of Baltimore, fitted up a camnery for eanning sweet corn. Which afterwards was sold to Mr. F. is sears and successfully run to he the largest cugar corn factory in the Fast in the hands i his widow, Mrs, Sears.

1873.-Un March 3 d Congress passed an act to reeulate the shipping of live stock. familiarly called the twenty-eight-hour law. it requirer all stocli in transit to be unloaded, fed and watered every twenty-eight hours, unless transported in cars, boats n. other vessels, where they could be properly watereal and rested.

1873.-Doncaster. owned by Mr. Mierry. took the English Derby in a small field of Welve starters, the time being 2:50. Doncaster was sired by Stockwell. A dead heat Face resulted between Gang

18\%3.--George Grant. of Victoria, Kas., in ported three Iberleen-ingus bulls.

1873. - First importation of IRed I'olled attle into the United States by G. F Taber. Paterson, N.

1873.-Dr. Wm. MeMurtrie, Chemist of the Department of Asriculture, commenced in. Festigation to determine suitable locations for production of the sugar beet.

1873.--Aberleen-Angus cattle imported from Secitland by Mr. Grant, of Vietoria

1873. A ugust 9th-Fubbard, the great race horse, established the two and three-quartes. mile record at $4: 58 \% / 4$, which stands to-day is the greatest performance of its kind fubbard was by planet.

18:3, September 10th. Shorthorn cattle sale at New York Mills. 110 head sold for $\$ 383,000,0 *$ an average of a trifle over per head.

1873, September 10th. -Seven-year-old Shorthorn bull Second Duke of Oneida. solu by Waleott \& Campbell, of New York Mills. o ' 1 . J. Megibben for $\$ 12,000$.

18:3, September 1ith.- Seven-year-old Shorthorn cow, Eighth Duchess of Geneva. sold at New fork Mills io R. Pavin Davis, of Eingland, for \$10,000.

1873, Saptember 10th-Seven-year-old Shorthorn cow, I'enth Duchess of Geneva, cold at New York Mills by Walcott? Campbell to Farl Bective for $\$ 35,000$.

1873, September 10th. - Two-year-olil Shorthorn cow, First Duchess of Oneida, sold at New York Mills by Walcott \& Camphell to Lorul Skelmersdale for $\$ 30,600$.

1873, September $17 \mathrm{th}, \ldots$ At Sacramento. Calif., Occident establishes a world's trotting record in $2: 163 / 4$.

18:3, November $19 \mathrm{th}$. - The st. Louis Nailonal stock Yards were officially opened is a live stock market, although some stork had been recoivel and handled as early luring the vear as the latter part of June. I'he tirst oflicers were: A. M. Allerton, Pres. ident and R. M. Moore, Secretary and Treas. urer. 'The first Board of Directors was oomposerl of A. M. Allerton, T. C. Eastman, John B. Dutcher, Alexander ir White, Andrew Pierce, Augustus Schell, Azariah Boodl, Oscar 'Townsend, John B. Bowman. E. W. Woodward and William R. MeKeen.

$18 \% 3 .-1 t$ the cluse of this year 397 places were enumerated as containing one or more pork-packing entablishments.

1873. - A herd of fat beef cattle from tho range oi Mohtana, driven by a Mr. Forbes to Ogren, Jtah, and shipped to "Whicago. The cattle were ranged by Conrad Kohrs in the Sun River country.

1873.-Paris green first used as a spray for fruit trees about this time. 
1873. - Towest whent, in September, 89 cens; highest. in July, $\$ 1.46$.

1874. - In this vear the Wyoming Cattlo Growers Association was organized.

1874-Mr. Cartwright's honse Ceorre Frederick captured the Inglish Derloy in the time of $2: 46$. George Frederick was sires by Marsyas. The winner of second was Couronne de Fer.

18\%4.--In February. the National Livo Stock Journal reported pure-blood shorthorn bulls sold to Pexas cattle raisers whose names are mentioned here: Capt. of Mckinney, Collin county; Capt. Carr, also of Collin county; Capt. A. H Shoemaker, of Decatur, Wise county; Capt. $1 \mathrm{Ym}$. A. Rheea, of Colin county; John D. county: Gilles Flipnin. Samuel Skinner, Geo. Herndor and H. M. Porvin, all of Denton county: and D. C. Jordan, of Montague county. The importation was by W. R. Duncan, of MeKinney, Texas.

1874.-M. W. Dunham established an importing and breeding farm for Percheron lorses in DuPage county, Illinois.

1874.--First cotton-seed oil mill in Louisiana established at New orleans.

18\%4, July 1st... At a meeting held at Willis's Rooms, London, England, under the Fresidency of the Duke of Devonshire, to consider the retirement of Mr. Henry Stafford as publisher of the Shortiorn Herd liook, a shorthorn society was formed. which, among other duties, undertook the maintaining and yearly issue of the Herd Book.

1874.-Mr. If, F Euren, of Norfoll established the Fnglish red Polled Ilers Hook.

18\%4, July 16th.-Three-quarters of a second was taken off the world's trotting record, which had stood for two years, by Goldsmith's Maid at East Saginaw, Mich. This was in a race. The same year, against time, she further reduced it twice, the first lime to $2: 151 / 2$ at Buffalo, N. Y., August Tth, and Jater at Mystic Park, Boston, September 20 , to $2: 14$. Two full seconds were clipped off during this year, and all by the sreat daughter of Ablallah, 15.

1874.-Colonel Wm, S. King Shorthorns at Dexter Park, Chicago, May 21st. Seventynine animals sold for an average of $\$ 1,6 \% 8$ per head.

1874.-Lowest wheat, in October, $811 /$ cents; highest, in April, $\$ 1.28$.

1874.- Herd Bonk of So:tth Wales cattle issued. Tht "Castle Martins," or Black Cattle of South Wales.

18\%4. - The Buftalo eattle market received 504,594 cattle in $I \$ 74$ and shipped out 468, s. 1 of them. At that time Buffalo was the second largest live stock market, receiving 504,594 cattle, $1,431,800$ hogs, 783,800 sheep and 21,336 horses. In 1866 Chicago yassed Buftalo in cattle and hog receipts but not in sheep and horse receipts until much later.

1874.-First American Galloway Herd Book issued in Canada, bought in 1893 by American Galloway Breeders Association and brought to the United States.

1874. The Cullivator and Country Gentleman, issue onf October 29th, said: "English papers mention the arrival at Liverpool of 270 head of cattle from Ameriea, by steamer, to be disposed of in the Liverpoo niarket. The appearance of the cattle is spolien of as excellent. They weighed 1, Son to 2,000 pounds, and realized from seventeel to twenty-nine pounds in English money. They sold for $\$ \$ 2.2 S$ to $\$ 140.36$ per head in American money.

18\%4, August 13th.-Mambrina Gift be comes the first $2: 20$ stallion by trotting the mile in that time at Rochester, N. Y.

1874.-- English Christmas beef was mentioned in English papers of December, 187., as being the highest in thirty years. The figures mentioned were from $14 \frac{1 / 2}{2}$ to $22 \frac{1}{4}$ cents per pound.

18\%4.-Alex No, 1, a Poland-China boar and one of the earliest high-bred animals of the breed, sold by W. W. Greer, Ohio, to Klever Bros, of Bloomsburg, Ohio.

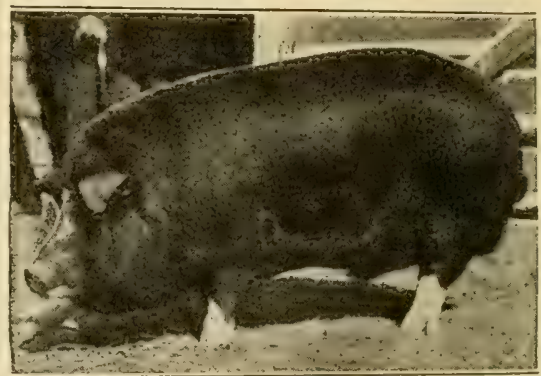

TVAIT OVER-POTAND-CHINA YEARLING BOAR. Champion Indiana State Fair. 1905. Exhibited by Pumphrey Bros., of Burney, Ind.

1874,--F, B. Rerlfield, of Batavia, N. Y. imported Aberdeen-Angus cattle.

18.5.--The Butman, originated by $\mathrm{Mr}$ Clarenclon Futman, of Maine, was the result of crossing the Hubbard squash with it Japariese race. It was the first American wquash.

18\%5. Fehruary 25th-American Berkshire Ismeiation organized at springfield, Il] First organization to systematically record Jedigrees of this breed.

1875.-Prince Batthyany won the English berby with the horse Gallowin, a son of Vedette, the time being 2:4s. Claremont was second.

1875. August 25th-Two-year-old shorthorn bull, Duke of Connaught, sold at Dunmore, Scotland, by Earl Dunmore to Lord Fitzhardinge for $\$ 26,904$

18\%5. -Bailey's shorthorn Reporter issued from ofice ot Mr. Allen, proprietor of the Shorthorn Herd Book.

1875.-Dispersion sale of Shorthorn herd of iVm. Torr, deceased, tenant farmer of Aylesly, Enfland. Mr. Torr once said: "It takes thirty years to make a herd and bring it to one's notion of perfection." His eighty-five animals sold for $, 943,144,57$, an average of $\$ 2,860.52$ per head.

1875, August 25th.-Earl Dunmore, of Stirling, Scotland, sold thirty-nine head of Shorthorns for $\$ 3,2 \$ 9$ per head, including a hull, the Duke of Connaught, for $\$ 26,904$. Highest prices were for cattle descended irorn American Shorthorns.

187., October 14th.-B. B. Groom \& Son, of Winchester, $\mathrm{Ky}$., imported Bates-brod Shorthorn cattle and held sale of these and others. Seventy-three head averaged $\$ 1,691$ er heed.

1875.-First regularly organized Experiment Station in the United States established $y$ the state of Connerticut.

1875. Lowest wheat, $831 / 2$ cents, in Februry; highest, in August, $\$ 1.301 / 2$,

1875.--In the Cultivator and Country Gentleman of February, 1875, Hon. George Geddes, writing in regard to the cost of beef, said: "Within a mile of my own house lives a Inan who lills about fifty beef cattle cvery week. He buys them in Buffalo and hrings them by rail to Syracuse, then drives them to his own farm, there slaughters them and sells their meat in syracuse. Mest of these catile have long, wide horns und are called Cherokee cattle. They averaged in live weight from 1,000 to 1,109 pounds and kill remarkably well, having lost in their long journey much of the liuids that helped to make up their weight where they were raised." The average cost to the buyer was four cents per pound at Ruffalo. He sold the beef at nine cents per pourid, the hitie and tallow at current prices. Speaking of the New York farmers, Mr. Geddes said: "Our farmers have found that L ruise a stuer to be three years old and more and sell his meat at nine or ten cents per pound is losing money, and they leave the production of heet for our own markets to Texas, the Chernkee Indians, or whoever may like to do that kind of business." 
187. - Southern-grown vegetalbles appearing in Northern markets began to have important effect about this time causing Northern growers to use more foroing louses in competition with them.

1875. - First shipmicnt of American fresh beef to England ty Timnthy C. Eastman, of New York, in October of this year.

1875.-Dr. Manley Miles bullt the first American siln for the storage of green focider.

1875.-Professor Carl I.inde invented the ammonia contpression machine, the basis of successful mott'rn refrigeration.

1875.--An era of speclalization in flower rrowing assumied considerable importance as this time.

1875.-On January 20 th of this year. Tohn B. Sherman, Superintendent of the Chicagrs Union Stock Yards, offered the ase of Dexter Park Pavilion, when not otherwise occupied, for the purpose of hotding public sales of pure-bred stock. In dates, such sales were to be under the management of Geo. II. Rust \& Co. promanagement of Geo. W. Rust \& Co., pro-
prietors of the National Live Stock Journal, which was the leading live stock paper in the United States during that verind.

1875.-In this year Mr. J. Moon, of Peytonville, Ark. selected seed from a single flant now called the
staple uplaind cotton.

1875. - First American Agricultural Kxperiment station begun by Wesleyan Unilersity, Middletown, Conn.

1875.-Preparing ensilage begun in this country, thoukh the Poman writers show that the process is a very old one.

1875.-R. W. Wilson, of California, planted fiftr acres in beets, onions, lettuce and car rots. for seed purposes. First systematio development of the seed-growing industry on the Pacific Coast.

1875. April 1/th, - Advance, Hereford bull. bred by ' $\mathrm{I}$ ' L. Miller first bull recorded in American Hereford Pecord. His sire, Success, 5,031, an imported bull, ivas recorded No. 2 .

1875. April 14th-Sale of Shorthorns first held at West Liberty, Iowa, by Mr. W. S iacobs. Finhty-three cattle averaged \$611.

1875, April 27th.-J. H. Pickrell sale of Horthorn eattle. Twenty-three sold at an average of $\$ 1,265$ per head.

1875, July, -The famous Poland-China boar, Perfection, 447, bought by Oliver Paddock, of Indiana, from IV. C. Hankinson, of Middletoivn, Ohio.

18.5.--Dairy farmers began to skim their milk and sell only the cream to the creameries.

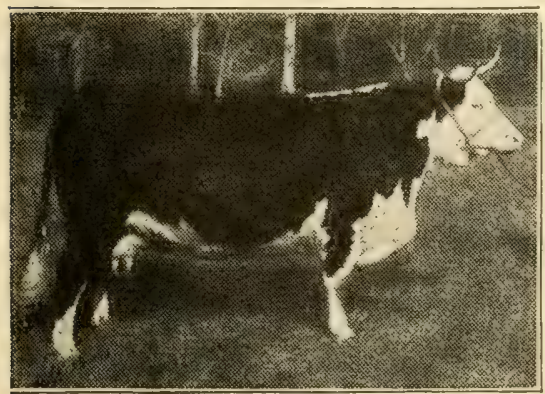

CHAMPION HFREFORD COW at the Jive Stock Show, Buenos Ayres, South America, 1906. Exhibited by Senor Pariera, This picture was obtained by Mr. C. $R$. 7 homas Secretary of the American Hereford Association, during a visit to Argentine.

1875, August.-At New York Mills, Almon IV Griswold sold thirty-three Shorthorn for an average of $\$ 1,697$ per head.
187..--Fitst important agrieultural and live htuk how at Palermo near Buenos Ayres, in somth America, given under the ussuices of tho hurat biocter

18\%6.-In this year I. B. Harris, of Tom reen county, leaxs drove zonot cuttle from Texas to slilene Kas, sajd to be the largest number driven by one outfit during the great dass of the cattle trall. They ere driven in difierent herds or bands.

18\%6.-Boone Cousity White Corm, one of ight recosnized varjeties, orifinated with lames liley, of Thorntown. Ind

1876, January 12th. - The Pliladelphin stock lards Company started in business this daie and went out of existence December $31 \mathrm{st}$, 1s96, succeeded by the West Phlladelphia Stock Jards Company.

1876.-Kisber, a son of Buccaneer, won the English Derby, the principal contender being the lorse Forerunner. The time, 2:44, was fairly fast. Kisber was owned by Mr. A. itlitz:z

1876. August 26th-Smuggler reduces the rorld's trotting stallion record for one mile 1876- At a poultry exhibit at Bangor. Maine, six white fowls were exhibited, called Snow Flakes and Dirigos. They were afterwards admitted to the poultry standard as White Plymouth liocks.

1876.-It was about the year 1876 when the cattle raiser obtained the benefits of the beef-canning business. The salt-benf trade had been very unsatisfactory for years. The inmense number of inferior to fair ivould be practically unsalable. In this emergency George Brougham, an Australian, arrived in Clyicago, bringing with him a practical knowledge of the beef-canning business, which had not been previously known or followed in Chicago. Mr. A. A. Libby, of the firm of Libby, McNeil \& I,ibby, employer Brougham and placed a fine article ot canned lieef on the market, and by the year 877 the firm had furnished a market for 100,000 cattle a year. The Fairbank Canning Company and Armour \& Co. soon became large operators in the canned-bee ade.

1876.-The Asromomic Institute of Paris. the highest institution giving agrieultural instruction in France, first opened to students.

18\%6. August 10 th.-The eight-year-old shorthorn hull, 14th Duke of Thorndale, soid at Paris, Ky., by George M. Bedford to Levi sofi

18:6--Percheron-Noman Stud Book issued, afterwards cailed the Percheron Stud Book. 1876.-At the St. I.ouis Fair in this year Mr. Alhert Rhodes, of Bridgeton, St. Louis county, $M \mathrm{C}_{\text {, }}$, had 125 varieties of apples on exhibition.

1876.-IIrid of Shorthorns established at Lintvood, Kas., by Colonel WV. A. Harris.

1876.-Charles Goodnight and John G ldair, pioneer cattle raisers in the Texas Panbandle, moved there from Colorado. Mr. roodnight had previously ranged in Palo Pinto county, Texas.

1876.- - National Norman Irorse Association rqganized.

18\%6. - In the winter of this year the outfit of Causey \& IVest operating around Yellow House Canyon, killed and skinned 7,000 buttalo. This was the last grand stanil of the immense herd, several million strong, that used to range between the Texas frontier settlements and the staked plains,

1876, September 16th.-Ten Broeck, the ramous race horse, established the record for two and five-cighths miles at $4: 5 \mathrm{~S} 1 / 3$ This record was made at the old Lexington tracl.

18\%6.-In the fiall of $1876 \mathrm{Mr}$. G. F. Swltht hipped from Chicago to Boston two cars of refrigerated beef. The establishment of the creat hnuse oz Swift \& Company dates from this time. The two cars went fcrward on a train which was mostly made up of stock cars. Dressed beef had been shipped before. but this shipment was followed up immediately and developed into an immense trade. 1876.--John S. Harris, of California, later of Oakley, Idaho, imported Angora goats. 
18\%6.--Beginning of low prices for cotton. Tpland midalins on New York market, highest of the year, $18 \mathrm{3} / \mathrm{s}$ cents per pound; bwest, $107 \%$ cents.

1876. - The germ theory of disease settled and accepted by veterinarians about this time.

1876. - The Journal of Commerce of New York, of December 30 th, 1876, said that the average price for the average grate of beves for the year was $\$ 11.13$ per 101 pounds aressed weight. The hide and tallow went to the butcher.

1876. - Lowest wheat, in Juily, \&3 cents; higliest, $\$ 1.26 \% / 4$, in December.

187\%.- The first number of the Farm and Fireside, an important and meritosious illusirated farm and family journal, was issue in this month at springfield, J. S. Crowell Manager; and T. J. Kirkpatrick, Editor. the paper was started as a semi-monthly at ,0 cents per year.

18:7.-Rutherford B. Hayes, President of the United States, and served four years.

18\%\%.-American Association of Importers and Breeders of Belgian braft Lorses organized. J. D. Connor, Jr, of Wabash, Secretary.

1437.--In this year Prof. E. H. Jenkins began testing seeds at the Connecticut Experiment Station.

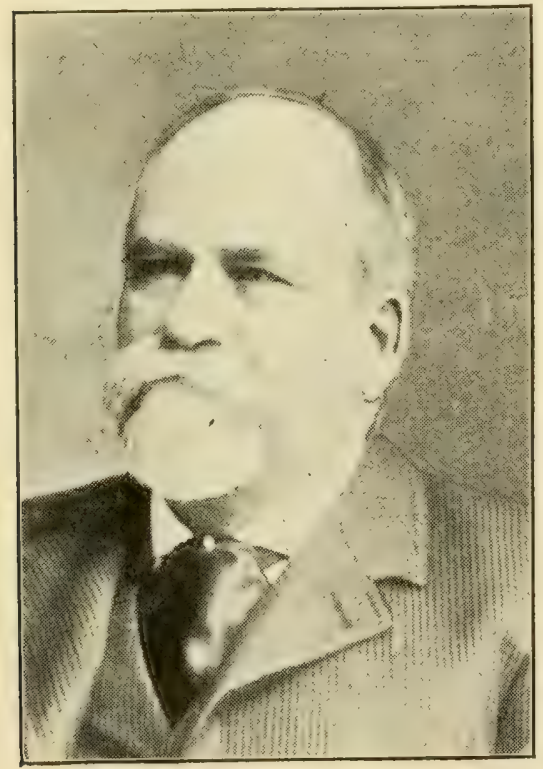

TAMES C. LOVING, of Lost Valley, Jack county, Texas. In the organization of the Northwest Texas Cattle Raisers' Association, in the year 1877, the matter of suppressing cattle thieves on the range and the recovery of stolen cattle in market was placed in the hands of JAMES C. LOVING, Secretary, who held the office for many years. Under his management the association became the greatest live stock organization in the United States of America, first embracing the whole state of Texas and later including a membership from Oklahoma, New Mexico and Arizona.

1877. February. - The Northwestern Texas Cattle Baisers' Association oranized at Graliam, in Young county, with C. L. Carter, President, and J. C, Loving, Secretary. This organization was afterwards enlarged to include the whole state, becoming the Texas Cattle Raisers" Association.

187\%-The Book on Swine IIuslsandry hy Hon. F. D. Coburn, of Kansas, issued in this year, had great influence in guiding and stimulating the production of hogs for marliet.

197\%. May 29 th. - The classic race horse Ten liroeck, a marvel of hi stime, went two miles over the Louisville rrack against time in $3: 27$. It was a most phenomenal perorrmance for the period. Ten Broeck was y Imported l'haeton.

187\%.-Cigdesdale Stud Book of Scotland suated.

187\%.-Galloway Society established in ireat Eritain.

18\% November $9+h$ and 10 th.-First Shortlorn sale at Kansas City held by $T$. Corwin Anderson, of Mount Sterling, Kentucky.

187\%.-Clydesdale Society of America ornized First Stud Book issued in 1882

187\%.-Mr. J.eDuc, Commissioner of Agri"ulture, introduced the "Zevinga," a Japanese variety of sugar cane, into the United States. 18:\%.-Great Eastern, bay gelding, by Walkill, dam Hamill mare, by Riley's Consternation, made the mile trotting record under saddle of $2: 15$, which record stands to-day, this fashion o fracing having fallen into

187\%.-Lowest wheat, in August, $\$ 1.01 \%$; highest, in May, $\$ 1.761 / 2$.

$187 \%$-- In September of this year a herd of cattle was driven from Yankton. Dakota, to the Cheyenne liver Agency, thirty-five miles ahove Fint Pierre, for the purpose of distributing them in the Indians to replace the ponies which had been captured from them in the campaign following the Custer massacre. The herd consisted of five hulls and 560 two-year. old heifers. The officer receiving and delivertng the cattle under contract was Lieutenant F. W. Mansfield, Eleventh Inited States Infantry, and the herd was in wharge of Mr. Philip $H$. Hale, editor of The History of Agriculture hr Dates, who was then an employe of the United States Quartermaster's lepartment. This was the begimning of domestic eattle raising on the lart of the Indians of the Northwest.

187\%--Tord Falmouth's Silvio won the Engiish Derloy, his principal contender being Glen Arthur, which finished second. Silvio was sired l,y Blair Athol. The time was 2:50.

18:7.--The Champaign County Gazette of 1llinois, of October, 1877 , reports the sale of 700 head of grass-ferl steers by Mr. B. F. Jarris to Monroe \& Son, of Albany, N. Y. of which the first 400 head shipped averaged 1,450 pounris, the others, equally as good, to follow. The report at the time was that $\mathrm{Mr}$. Harris sold the steers at five cents per pourd, live weight, delivered at the railway station.

187\%.-In this year the Chicago Drovers' Journal mentioned that an enterprising canring firm has received an order from the Russian government for every can of beef they conld put up in a year. This was the heginning of the large orders which packers have oncasionally obtained to clear away the inferior grades of cattle and which could not be lought for any other purpose.

18\%, Ontolver,-Tom Corwin, 571, one of the farly famous Poland-China boars, bought by $W$. O. Reveal, of Clermont, Ind, of James Duflield, of Sumerville, Ohio.

1878. -The National Live Stock Journal mentioned a Champaign county (Illinois) iarmer who in April, 1878, bought a lot of 1,040-pound steers for $\$ 3.75$ per 100 pounds as feeders and returned them to the chicago market, December inth of the same year, weighing $1,4 s 0$ pounds. He sold them at $4.121 / 2$ per 100 pounds, This was before the iressed-heef houses were in the business.

1878, August 3a.-After four years of reign as Queen of the Trotting Turf, Goldmith's Maid was dethroned by Rarus, who, triven by John splan, at Buffalo, N. Y.. brought the trotting record to $2: 13^{3 / 4}$. $\mathrm{He}$ was a bay geiding by Conklin's Aldallah, his lam by Telegraph.

1878.- The Pictet Artificial Ice Company fitted up a building in Greenwich street. New York Citv, for the purpose of holding fruits in cold storage for the people.

1878. August 7th.-Sleepy George makes world's record by pacing a mile in $2: 15$ at Rochester, N. Y. 
1878. Galloway Society of Scotland published first volume of pedigrees.

1878. - The IBamanas rose sent to America from Japan by Thomas Hogg ahout this time.

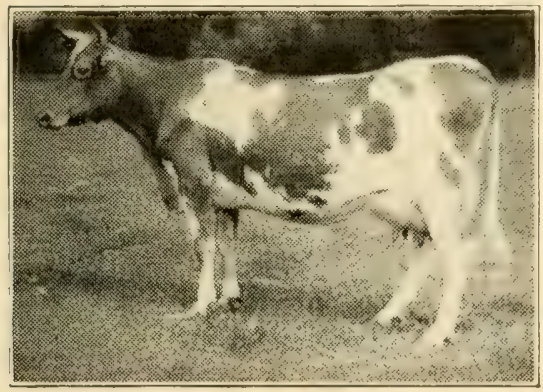

DOLLY BLOOM-Guernsey cow. One of the most famous of that great dairy breed.

1878.-American Guernsey Cattle Club or ranized in this year.

1878. - English shire Ilorie society formed and a stud hook provided for.

1878.--First American lat stock show. Champion beef animal, the Shorthorn steer John Sherman, exlibited by Colonel John D Gillett, of Fikhart. Ind.

1878. Hog prices at Chicago, January 1 st. 1875: Heavy shipping hogs, $\$ 2.75$ to $\$ 2.45$ ner 100 pounds; heavy packing, $\$ 2.60$ to \$270: ight iacon grades, $\$ 2.70^{\circ}$ to $\$ 2.75$ skips and cul!s. $\$ 1.50$ to $\$ 2.25$ per 100 pounds,

18\%8. Young Perfection 631, one of the hest loland-China boars of his day, sold by Josewh Mortor, of Oxford, Ohio, to D. M. Magie, of the same place.

1878. Lowest wheat, in October, 77 eants: highest, in April, \$1.14.

1878. - The record for a ten-mile trotting race was made hy Controller a son of General Taylor. The time was $27: 331 /$, and was the hesi, in a race. since $1 \$ 53$.

1x78-- Anderson $\&$ Findlay, of Lake Forest, [1]., imported Iberdecn-Angus cattle.

1878.-Mr. J. J. Gregory, of Marhlehead, Mass, an authority on the subject, esti. inated 7000 acres as the total area devoted to commercial seed growing.

1878.- The knylish Merby was won by Mr Crawford's horse Sefton, sired by Speculum. The time was slow, being "2:56. Insulaire ran a good second.

1879.-On the 31 st day of October the husiness career of the Matadior Cattle Company hegan, with headquarters at Teepee (ity, Motley county, Tcxas. Judge $H$. (Paint) Garnpbell was General Manager.

1879.--The Shorthorn steer Nichols, three vears old, champinn at American Fat Stock Show, exhibited by , J. H. Graves.

1879. - American llereford llerd l3onk founded at Heecher, Ill, by 'T. L. Miller.

1879. - Dark days of the shorthorn cattles hreeding and speculative interests. 2,865 Shorthorns soid at an average price of $\$ 115$ ler head.

1879--Lowest wheat, in January, $81 \mathrm{z}$ cents: highest, in December, $\$ 1.331 / 2$

18\%9.--The Allen Long Staple, an upland rotton intrinduced by Mr. J. B. Allen, of Port Gibson, Miss. This caused a marked advance in the development of long-staple upland in the development of long-staple upland stalk of Bohemian cotton, a Louisiana variety. origin unknown, and from this developed several other seed cotton varieties originated hy Mr. Allen.

1879.-In Eebruary of this year, in the Cultivator and Country Gentleman, a reference was made to the Chicago Live Stock Reporter, whirh thinks that the driving of

Texas catile up the trail will soon cease.

This opinion is based on the fact that a large shipmert of Texas cattle had been receiver at ("hicago from S. R. Hilbourn, of Waxahachic, Texas, who had feri them thero

18\%9.--Sir lievys, a horse hy Favcrius, won the English berloy for Mr. Acton. T'le time was the slowest in the history of this great (lassic, heing $3: 0$. The field consisted of venty-three holves.

1879.-.-The National Live Stock Journal of Chicago, of June, 1879, writing on the price of beef cattle, said that a zood steer would soll for $\$ 5 .(4)$ ber 100 pounds in Chicago, and that first-ciass steers would bring more. The item began 1, saying there was discouragenent, lewression, sometimes present loss in the prorluction of a number of prominent arm products, but cattle were an exception.

18:9.-From an aunual review of the live tock trade oi Chicasn for 1879: "Warly in the vear the export trale in live cattle with Great Pritain was brnught to a sudilen check fy regulations which prohibited our ship. inents from entering their ports, except inder such restrictions as practically ended il business in this direction thus reducine the shipments of live cattle abroad to a minimum, but the increased exports of dressed and canned beef by the refrigerator ystem have fully made up the dificit.

1879.- The date of the opening of the prinipal beci-pacting houser is a very importint iten, because there hegins the general stability of the beef trade. Nelson Morris \& Co. commenced lusiness in a portion of their resent packing house at Chicago on June 7 , 1579. The Fairbank ('anning Company, which was under the same management and control is Nelson Mrrris \& (o., started cannins meats about two weeks later. Mr. Nelson Morris nreviousiy owned and conducted a laughtering house on the Chicago lake ront.

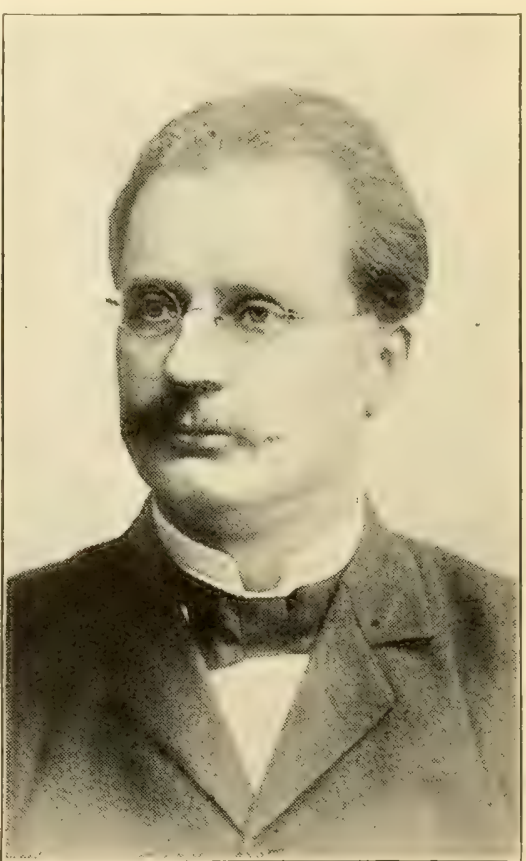

DR. CARL GUSTAF PATRICK DE LAVAI, of Stockholm. Siveden, inventor of the Centrifugal Cream Separator.

1879. Centrifugal cream separator inrented by Dr. Gustav De Laval, of Stockholn. Sweden. Great benefit to dairy interests, enabling the separation of cream from the milk while both are sweet and fresh from the cow. 
1879. - St. Julien placed the trotting record at $2: 133 / 4$. The performance was made at Oakland, Calif., the horse being driven by Orrin flickok. He was a bay gelding by Volunteer, dam by Henry Clay, 45.

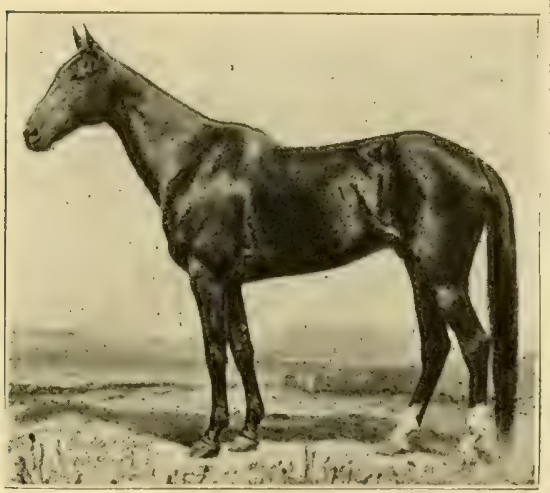

ST. JULIEN, $2: 11 \frac{1}{4}$.- Schreiber photo.

1879. November $19 \mathrm{th}$. - The trotting standard adiopted.

1879, December $2 \mathrm{~d}$.-At Billerica, Mass, on "Willing Farm," owned by Mr. Jno. M. Bailey, the first American silo was opened in the presence of a distinguished gathering of agrirulturists. oflicials and editors. The silo contained 120 tons of ensilage. The experiment was a success, and with the exception or two or three inches at the top, which was musty, the silage vas good and readily eaten hy stock.

1880.-J. B. Evans, an enterprising farmer in Cape Colony, South Africa, went t"s Angora, in Asia Minor, and obtained the finest specimens of the Angora soat which up to that lime hal reached the colony.

1880. - White Superior, a standard variety of corn, orisinated in this year by $P, R$. perry, of Moninouth, Ill.

1880.-Ascociation of official agricultural fhemints organized.

1880. - Special contest of baling presses for hay and straw at New York State Fair. First lirize a warded to Whitman Agricultural Company, of St. Louis, Mo., the same firm winning four successive years.

1880.--Irown swiss cattle breeders organized and commenced publication of a herd iecord.

1880. - Center of population of the United stales. eight miles west by south of Cincinnati, Ohio.

1880. - Last class for four-year-old beef neers at American Fat Stock Shows.

1880. - The Shorthorn nteer Nels Morris, weighing 3,125 pounds, exhibited by $\mathrm{Mr}$. John B. Sherman at the Union Stock Yards.

1880.- Importation of Gothland swine from Sweden by Mr. S. V. Anderson.

1880- First volume of the English Stud bool for shire or Cart Horses published.

1880. April 29th.-American Jersey Catle ('lub ineornorated hy Richard M.Hoe, Thomas H. Faile, Wm. B. Dinsmore, Erastus Corning, John D. Wing, Samuel J. Sharples, John Carter Brown, IVilliam S. Taylor, Joseph H. Reiman. John Hoey, Ldwin Thorpe and Herhert M. Howe.

1880 - On June $25 \mathrm{th}$ of this year the German government issued an edict prohibiting the importation of "chopped or in a similar manner divided or prepared pork. and of sausages of all kinds, from America."

1880.-The American Wonder a dwarf pea, produced this year, was a combination of McLcan's Little Cem and the champion of New England. It was a distinct step in the improvement of pea culture

1880. - First fencing in the Panhandle of Texas on the ranch of Adair \& Goodnight. The barbed wire cost nine cents a pound.
1880.-Mr. E. Moullee, of Jacksonville, Fla., started a perfumery farm at San Mateo, of that state, using orange and lemon fruits and flowers.

1880. - The United States Census reported 4,005,307 farms in the United States, an increase of $1,384,922$ in ten years.

1880.-The Elberta peach (Chinese Cling) introduced into the Southern States.

1880. Center of the number of farms in the United States, twenty-one miles south by east of Cincinnati, Ohio, in Kenton county, isentucky.

1880.- The Duke of TVestminster captured the American Derby with the great horse Ben d'Or, by Doncaster. Robert, the Devll, was second, and the time was 246 .

1850.-Mr. Gulian P. Rixford, of the San Erancisco (Calif) Bulletin, imported cuttinurs of the best varieties of smyrna ligs from Smyrna, in Asia Minor. This importation was a fillure, supposedly owing to bad faith on the part of the Smyrna fig growers who old the cuttings.

1880, April.--George F. Loving commenced publication of Texas Live stock Journal at Weatherford.

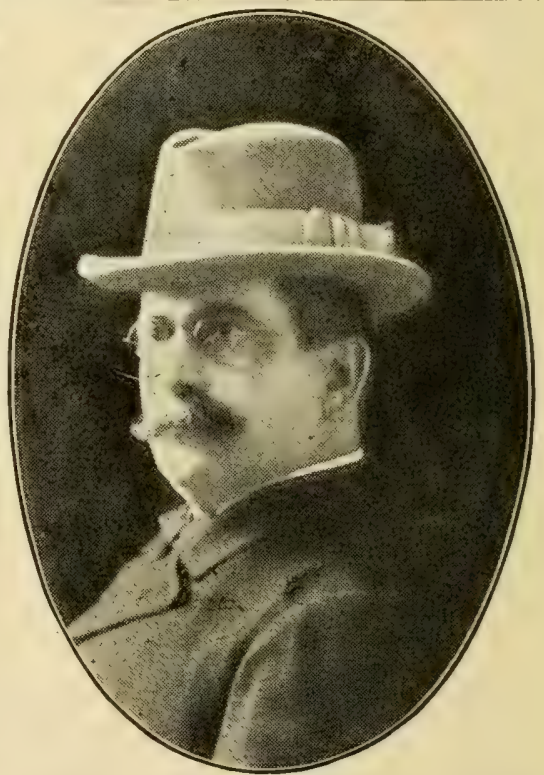

GEORGE B. LOVING, of Fort WVorth Texas, in publishing the Texas Live Stock Journal, the first ranchman's paper, invited the attention of the world to the ranch cattle industry, and more especially to the cattle-raising interests of Texas. He was the son of a pioneer cattleman, Oliver loving. who tost his life in defending his herd from Indians on the Chisum cattle trail.

1880. Alusut 12th.-Maud $\mathrm{S}$. made her appearance as trotting champion at Rochester, N. Y., where, driven hy W. W. Blair, she look a full second off the trotting record croins the mile in ?:11 s, She was a chestnut mare by Harold, dam Miss Russell, by Pilot. Jr.. and in her six-year-old form. Fifteen days later St. Julien reduced the malk to $3: 11 \frac{1 / 1}{1}$ at Hartford, Conn. Before the vear was uut Maud $S$, again assumed the record hy a mile at Chicago, Ill., in $2: 10 \% / \mathrm{s}$.

1880, Septentber 16th.-Goat show at Alexandra Palace. North Iondon, supported by the Birisish Goat Society.

1880.-During the week ending November ?0th, the record for a week's receipts of hogs was made by Chicago, Ill. The total was 300,488 head.

1880 - During November, record receipts of hogs for a month were made at Chicago, Ill, The record is $1,111,997$ head. 
1880.--Lowest where in August, $861 / 3$ cents: highes?, in Janiary, \$1,32.

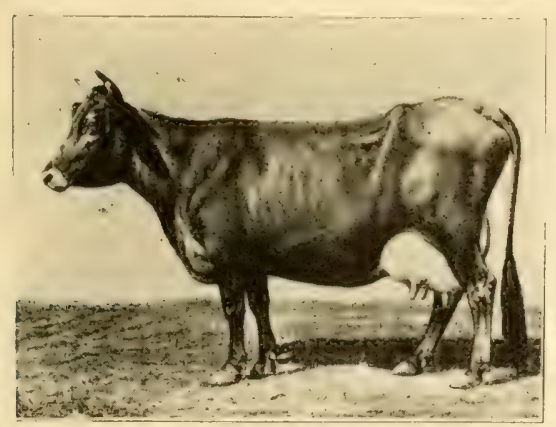

MATIIDA, 4th-Famous Jersey cow.-From nhoto by schreiber.

1881.-In tize Januarv, 1SS1, issue the Tansas City Live Strock Indicator reported that J. C. Jones, of Coiorado, had soll $\mathbf{3 0 , 0 0 0}$ cattle to Towers, Gudgell \& Smart at $\$ 17$ per head, calves counted.

1881.--First improved stock car originated liy Mr. A. C. Michers.

1881, March 1st.-First recorded contrivance for mechanically pressing silare, patented by Iavi H. WWhitney, of Lowell, Mass.

1881, March 5th.-First number of the chicagn Horseman issued, with E. L. Stotve as editor.

1881- The English Derby went to Pierre Lorilard's grand race horse Iroquois, by leamington, with Peregrine second. Time, $2: 50$.

1881.-Apricot, or Simon Plum, native to China, introduced into this country.

1881. - James A. Garfield, President of the United States, and served until he died, September 19th, from wounds inflicted by the assassin.

1881. - Mcchanical Refrigerating Company opened a commercial cold-storage plant in Bosinn, marking the beginning of mechanical refrigeration in resard to horticulture.

1881.- The first iron greenhouse in the linited states eercted this year.

1881. Tune :2a-American Hereford Cattle Brepleas" Asaciation organized. C M Cul hertson, President; 'T'. E. Miller, Secretary.

1881, July 16th.-Swannanoe, an aged horse by Red Dick established the mile record of $1: 50$ in a hurdle race at Brighton Beach, N. Y. He carried 120 pounds.

1881: Juiy 19th.-Speculation, a running horse by Daniel Boone, ran a mile and a half oier hurdles at the Brigton Beach Course, New York, in 2:47. The same time under the same circumstances and at the same place, was made by Kitty Clark, by Glenely, on August 23 d, the same year.

1881, A ugust 11 th. Trotting record reduced twice by Maud S., finally placed at $2: 10^{1 / 4}$ at Fochester, N. Y.

1881.--Turkey prohibited the exportation of Ingora goats.

1881.-." "The coming American cow will be of the Shorthorn type and hornless." - Hon.

I. N. Bonham.

1881 - - John D. Gillett's red Shorthorn bulluck Mclullen. champion of American Fat Stock Show, weighing. 2,095 pounds.

1881. - Stud Book issued in France for the Nivernais (black) draft lorses.

1881. - Little Brown Jug, brown gelding, by Gibson's Tom Hal, dam Lizzie by John Netherland, reduced the mile pacing record to $2: 11 \%$. This at Hartford, Conn., August tith.

1881.- Hreeders' Gazette established at Chir:ago by Mr. 'J. H. Sanders.

1881.-Lowest wheat, in January, $95 \%$ cents; highest, in October, $\$ 1.431 / 4$

188: - The sweet pea began to be placed in flower seed catalogues about this time.
188:- - In his American Orchardist, James Thatcher says: "The sedelo for plantior should allays be selecterl from the most highly-cultivited fruit and the finest and ripest specimen of such variety.

188:, January - I Jarge hog was exhibited at Junction City, Kansas, said to weigh 1,532 pounds.

18.:- - Il, II Hate of chleago, formerly of Menry count: Jllinois beran a series of articles in favor of feloorning eattle.

188\%, Felimary 224.-Ohlo Suanimh Merino

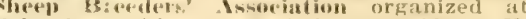
columbus, ()hio, (i, H3, Ouinn, President: $H$ Denter, First Vine-president: B. IV. Bell. Second Vice-president: ('aut J (4 Blue secretary; $1 \mathrm{Vm}$. Kennndy, Treasures.

188:- Brienzi lfs, a noted IBrown swisis "ow, intuorled this yeit she lecame the most nuted colv of the lreed in this country. At eleven years oin she weighed 1,410 pounds. lier three-day show record was 81.7 pounds of huter-fat equal to 313 pounds of merchantable hutter each day.

188\%, February. - In this month the great cight-year-old white steer. Nels Morris, that and been exhibited at several Chicago Fat stock Shows, was slatehtered. His gross eight was isSo pounds, and he dressed 076 pounds.

188:. March, - In this spring a feature of the live stock trate of Chicago was tho arrival of large numbers of stock rattie from Western Pennsylvania. This indicated the lonal abandonment of cattle raising as a business and the weakness of the seaboard markets as regards anything except choice cattle and calves.

1882, April.-Sheen sold at the Chicagn market at $\$$. per 100 pounds, highest price on recoril.

188\%.- "I2atis" victuria swine oiven a class at Illinols Strce Fair. Originated by George Poland-China. Chester White, Berkshire and American, or White Suffolk.

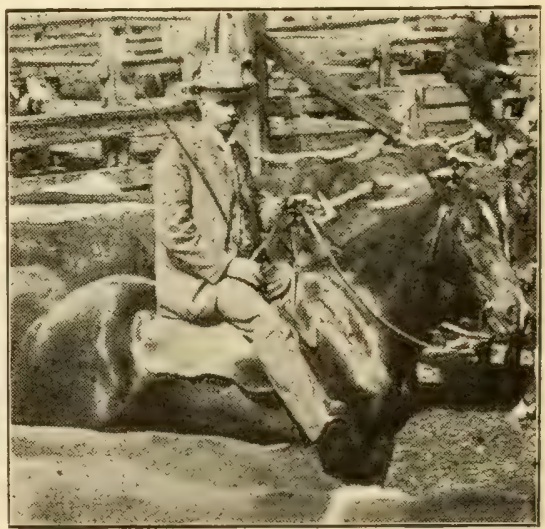

THE FIRST TRAIN OF GRASS TEXAS CATTLE to sell at seven cents per pound were sold by Hunter, Evans \& Co. on the St. Louis market. The picture is that of MR. M. P. BUEIs of the firm of Hunter, Evans \& $\mathrm{Co}$

184:. May, - A train of Texas oattle shipped hy Colonel $C$ C slaughter, of Dallas, sold on the St. Luuis markit at seven cents per pound.

1882, June-Native beef cattle sold at Chicago on the general market at $\$ 9.30$ per pounds.

188:, Ju!y 25th.-At Saratoga, N.Y., Ben WOr by Bucleden, placed the record for mile and tive humblred yards at $2: 101 / 2$

188\%, September.-Heavy logs sold up to $\$ 9.35$ per 100 pounds at Chicago; highest price on record. 
188:- First Ensilage Congress held in New York City, It was resolved that the ensilage system is of great advantage to the farming interest and to all mankind.

188:- John D. Gillett's Shorthorn steer time victor at the American fiat stock Show having sained 470 pounds during the Show weisht, 2,565 pounds.

1882, November 9th.-The mile and a quarter race record over hirdies was placed Dance rinis time was made at Brighton Beach. N. Y.

188\%.-One of the early farm newspaper articles concerning the great packing houses appeared in the Country Gentleman, of Albany, N. Y., December 7th, 188\%, as fol lows: "A single meat factory, so to speak, the noted establishment of Arnour \& Co., every day of 700 or 800 cattle, mostly Texans, and $\delta, 000$ to 1:000 hogs, every one of which is slain on the premises and worked up into all possible products, hardly au ounce of the whole vast hulk going "ntirely to waste. A visit to this establish ment is of the utmost interest to those who care to see the wonderful results that can co-0peration and the emmloyment of steam iriven machinery for the relief of human muscle

188\%.-Lowest wheat, in December, 911/8 cents: highest, in April, \$1.40.

188:-Shotover, ownerl by the Duke of Westminster, won the Lnglish berby in Quicklime finishing second.

188:- The tuberculin test for tuberculosis first seriously considered as practical by Dr. D. E. Salmon, Chief of the United State Bureau of - Animal Industry.

1883.-Ormoude, the thoroughbred, was foaled at Eaton Hall, seat of the Duke of Westminster. He died at Menlo Park. Califorma, twenty-ore years later. He started the English Derby, two thousand guineas, and st. Ledger. IVm. O'Brien McDonoug? of California, paid $\$ 150,000$ for him. He was a majestic bay, 16.1 hands, and conhis day.

1883. - The Wyandotte breed of fowls received their name in this year. It was proposed hy Mr. Houdlette at Worcester. Mass. Pay, of Hemlock, N. J., by a eross of a Sebright Bantam male with a yellow "Chitatong," which he named Sebright Cochins, Rey. A. S. Baker and Mr. Benson also produced similar fowls.

1883.--Roan Bov, Shorthorn steer, champion of American Fat Stock Show Exhibited by $C$, M. Culbertson, of Newman, I11.

1883. - Peter Collier of New York, patented an invention for recovering sugar from begasse, or refuse of sugar cane and sor žnum.

1883.-American Red Polled Cattle Society organized, J. C Murray, of Maquoketa, lowa, Secretary.

1883.-First volume of the North Wale

black Catte Iterd Book issued: the second in 18.86 .

1883,-Fercheron Iorse stud Book established in France.

1883, April 18th.-R. Gibson, of Delaware Ontario, and Rigdon, Huston \& Son sold Shorthorns at Dexter Park, Chicago, and thirty-two animals were sold for $\$ 33,645$ an average of $\$ 1,1+1,35$. The highest anima in the sale was the First vuchess of Hilldale. sold to Charles DeGraff, of Winona, Minn,, for $\$ 6,1000$.

1883.--De Laval eream separators first introduced and sold in the United States.

1883. - First year that middling upland cotton reached 20 cents per pound in New York City.

1883.-The Grove, $3 d$, Hereford bull, at in wine years

1883, April 19th,-Two Shorthorn sales: Launcelot Palmer's Scotch at Dexter Park Chicagn; twenty-five head averaged $\$ 625$ Bow Park/Bates cattle, thirty-six head. averaged $\$ 325.55$
1883.- Lowest wheat, in October, 90 ents; highest, in June, $\$ 1.131 /$

1883. - St. B!aise, the famous race horse and sire, won the Fnglish Derby for Sir F. Johnstrue, the time heing $2: 482-5$. He was the second son of Hermit in succession that n the Derby.

1883, September $3 d-$ - Jay-Eye-See trots in $: 10 \%$ at providence, Fi. I., establishing the vorld's gelding record.

188:- The Allen Shorthorn cattle recoris curchased by the American Shorthorn Breeders" Association for \$25,000.

1883.-The London Mark Lane Express ays: "The clead-meat tratlic is beating the live-cattle traftic in the United States, and it would inat it in the trans-Atlantic business if it hark fain play"

1864. The Isureals of Animal Industry istablished to investigate and report upon lomestic animal riseases.

1881 - At the sit. Touis Cattle Growers onvention, hela in November, 1884 , Mr. D. Wetzel, Assistant Secretary of the Colorado Cattle Growers" Association, said: "At this time there is an irrepressible conflict between the live stock shippers and the claughterers. The live stock dealer, the middleman, is only a speculator and the midaleman must $r o$, and the two controlling and only elements of the beef trade of the country will be narrowed down to the ranchmen and the slaughterers.

1881.- - it the Cattlemen's Convention, hela at St. Louis, November 17, 1884, Mr. Isaac II. Knox, then President of the St. Louis National Stock Yards, said: "It is one thing to kill cattle and another to dismose of the product. Slaughtering is the cheapest part of the whole business: the thing is to find a market. To sell the refrigerated product requires agencies and cold-storage houses in the East, and as it costs at least $\$ 1.500$ to build the smallest kind of a cold-storage house, it can easily we inderstond that to conduct a business of such a character requires enormous capitat," "This was in the early days of the lressed-heef business.

1884 - $\Delta t$ the St Iouis Cattle Growers' Convention, held in November, $1884, \mathrm{Mr}, \mathrm{H}$ L. Faust, of Salt Lake City, said: "In addition to the other schemes to be considererl we will present the question of refrigerator cars. Jt is one of the utmost importance to the beer consumers of the East. If we could slaughter out West, instead of shipping our live cattle to the East, it would be an cnormous saring to the consumer."

1884.-In this year a shropslire record was established in Indiana by Mortimer Levering, Albert Henderson, Walter J. Quick, John L. Thompson, I. J. Farquhar, Geo. Allen, Sr. and W. C. Latta. The association was and is known to-day as the 1 merican Shropshire Fegistry Association.

1884-A variety of Jong-staple upland cotton named "Conk," after the originator, was selected this year in a field of ordinary cotton hy Mr. Wr. M. Cook, of Newman, Miss. Extensively cultivated in the Delta Region of Mississippi.

1884.-Beginning of four-years' low prices of wheat. Lowest price for No. 2 cash wheat, in Dectmber, $691 \%$ cents; highest of the year, in February, 96 cents.

1884.--A dead heat was run in the Wnglish Derby between Mr. J. Hammond's great horse, St. Gatien, by Rotherhill, and Sir S. Willoughby's Harvester, by Stirling. The time was $2: 461-5$. This was the first time in history that the Derby went undecirled.

1884. April.--National Stockman, published nt Fast liberty, Pa., mentions 1141/2-pound Yelaine Merino sheep fed by James McCleliand, of Cannonshurg, Pa., which sold at ren cents per pound.

1884. May Sth.-The National Dickinson Suarish Merino Register incorporated in chio by James NeDowell, H. G. McDowell, TVm. Beecher, Henry Everhard, G. W. Heldenbrand and A. C. MeDowell.

1884, May 19th. National Meetting of Wool Growers presided over by Hon. C. Delano at Chicago.

188t--Boulonnuis Stud Book established in France. 
1884, June J1th and 12th.-A. C. Hamilton held a male of shorthorns at his farm near I.exington. Ky., at which an

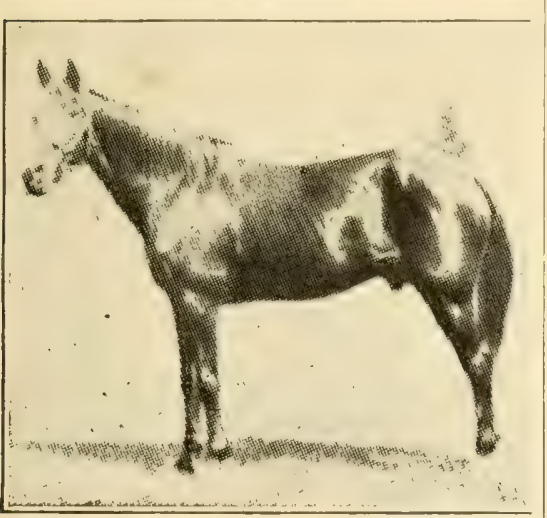

J $\triangle Y$-EYE-SWE. Picture taken in his old age. This famous black gelding by Dictator was the first $2: 19$ trotter, having trotted a mile in that time in record of $y: 0 ! ; 1 / 4$ as a pacer. He is therecore champion combination trotter and pacer of the world.

1881. August 1st--Jay-Eye-See, a hlack gelding, becanie the first $2: 10$ trotter, establishing, that reeord at Providence, $R$. I He was a son of Dictator, his dam Midnight, i) Pilot, Jr.. and was driven by Edward Bither. The next day Maud s., driven against time at Cleveland, Ohio, set the mark at $2: 093$, and later in the year, at Lexington, ky brought it to ":09 1/4.

1881. August 2sth.-At Leominster, England, the Iferctord bull Lord Wilson, at nine rears olr, sold for $\$ 20,000$.

1881.-Clarence Kirklevington, the 2,400, pound White shorthorn, won the championship at the (hicago trat Stock Show.

1884. - National Norman Horse Association incorporated under name of National French Draft Horse Association.

1884, Seotember fith-Drake Carter, a son of Ten Broecle fixed the three-mile rumbing mecord at $5: 24$ at Sheenshead Bay, N. Y He carried 115 pounds in foing the distance.

1884. Detober. - Famous Poland-China boar, Bravo, 337 , bought of 5 lever 13 ros. of Bloomingshury, Ohio, by Walker \& Son, of New Madison, Ohio, for $\$ 300$.

1884, October yth.-At Chicago, Johnston, the reat pacer, by Joc Bassett, dam by Ned Forrest, set the pacing record at $2: 061 / 4$.

1884. November $18+h$ - In a few remarks adidresser to the Cattlemen's Convention at St. Louis, Gen. W. T. Sherman said: "I sometines deplore the disappearance of the biffalo, olk and antelope; but although these animals have disappeared, you have replaced them with probably 20.000 .000 of fine bred stock which sumply us with meat we eat ind surply too much of the meat which is waten in lurope.

1885,-In January, 1SS5, the Commercial Bulletin of Boston expressed satisfaction at a decision of Judge Cooley, fixing rates on dres-ed beef 75 per cent. higher than the rate for live cattle. Attention to this discrimination against dressed beef was invited by an article in the National Live Stock , Journal of January 6. 1885.

1885. - F T. Maslin of California, planted Smyrna reeds from best figs imported by the wholesale trocery house of $H$. K. Thur her \& Co., of Ne'v York, from which were wrown large and llourishing trees.

1885.- On March 10; 1885, a London paper announced that P. D. Armour \& Co, had sold five million cans of fresh and corned beef to be used by the British army then
Joing service in the souclan. 'To supply this ontract refuired 70,000 liead of live cattle. 188\%.-The Boston Inally Advertiser of March 14. 1S35. anmounced an auction sale of Wentern dresmed becef, the first sale of Its kind ever hold in that city. Over 300 market men werc assmbled. The heef was sent there in refrigerator cars liy the st. couis Beet ('anning (ompany, Wm. H Monsoe, Manarer. \t lirst the hind fuarters olil at $111 / 6$ cents, and fore quarters at is cents per pound; later the prices ranged rom $\mathrm{S} 3 / 2$ to do cents for hind quarters and chis for fore quarters.

1885--10r. W. \& Caruthers, of Cotulla. exas, a retired army surgeon, associated ith Mr. 'T. R. Keck, originated a machine hereby the prickly mear, abundant in sonthern Texas, could lie cut up and fed to rented to huru the thorns ofl as a further 1885 - First meting of the society of Imerisan florists held in this year. M. ohn 'Thorve was Presiclent. 1885.- - The Lnglial, Derloy was won by ord Hasting's Nelton in '2:4.4 $1-5$, Paradiox finishing second. The winner was sired by 188.5.-Crover Cieveland. I'remilent of the united staten, his tirst term, serving four

188.j-National Lixe Stock lixchange or anized, President, WT. H. Thompson, Jr. ice-Iresident, Levi H. Doud; Secretary, $\mathrm{C}$ IV. Baker: Treasurer. G. W'. Shannon.

1885,--liley's liavorite, one of the recognized varieties of corn, originated in this ear by James IRiloy, of Thorntown. Ind. 1885.-In this year a ehestmut horge amed Bull, but of pedigree unknown. rotied eighteen miles in harness, in a race,

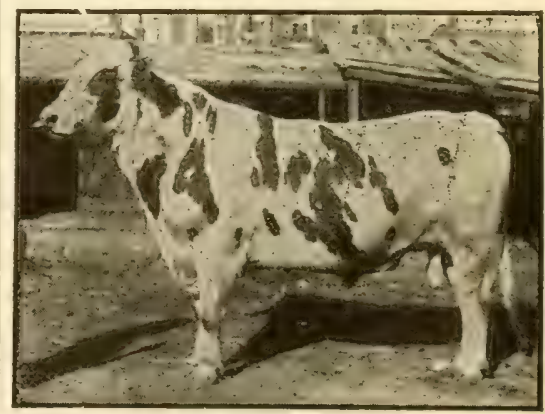

HOISTFIN-FRIESIAN BULL-Champion $t$ the St. Inuis Fair. Owned by M. E. Ifoore, of Cameron. Mo.

1885, May 25th.-Holstein-Friesian Association of Imeriea incorporated by Theron i. Jenmans, William M. Singerly, William Brayton, Thomas B. Wales, Jr., Gerritt S. Miller. Frederick C. Sterens, Wing R. Smith, 3. D.Guthie, Freflericl? J. Houghton, Francis II. Patlerson, Ware Emirick, George A. Jackson, H, H. Hatch, William IJ. Heningway, Daniel D. Durnall,
Irwin tangworthy. John B. Tuckerman, charles R. Payne, Robert Burch, E. R. Phillips anil sulomon Hoxie.

1885, July - J. J Coffman, of Danvers, Ill.. bought of Klever Bros., of Bloomingshurs. Ohin, the famous Poland-China boar recuimseh, 4,339 , for $\$ 500$.

1885.-Clingstone, by Rysdyk, and Guy, by Kentucky Prince, trotting together as a team against timie, set the mile recori at

1885 - "Dandy" seven-months-old Davis Victoria boar. vinner of grand sweepstakes over all other breeds at Worla's Industrial and Cotton Exposition, New Orleans, La.

188.5.--MI: 3. B. Warren, of Larchwood, Invil imported thirteen head of Nortin Wales IBlack Cattle from the Island of Angleseit. 


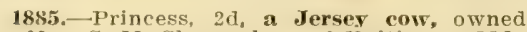
hy Mrs. S'. M. Shoemaker, of Baltimore, Md. reported as havins made over 46 pounds of butter in one week. Actual 46 and 50-64th younds. The milk yield was 16 per cent fat

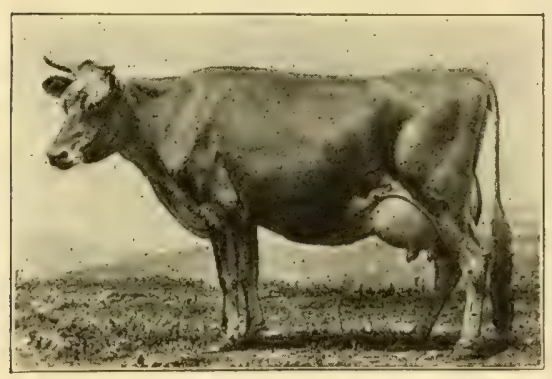

JEIRSEY (OW-PRINCESS, 2d, 8,046: Reputed record, 46 pounds $121 / 2$ ounces of lutter in seven days. Owned by the late 5. M. Shoemaker, of Baltimore, Md. From copyright photograuh by permission of schireiber \&: Sons, of Philadelphia, Pa.

1885. - Mr. J. C. Duncan, of Normal, Ill., imported "Normandie" cattle from France.

1885.--fuly, at son of Narragansett, negotiated a mile and threc-eighths over hurdes in 2.35 , at Latonia, Ky.

1885. Mr. Albert Montgomery, of New Orleans, La imported Brahmin or "Bouchour" catlle from India.

1985.--Tine Hereford steer Regulus, exhibited by Fowler \& Van Natta. champion 1885.-Lowert wheat, in March, $73 \%$ cents; highest, in April, $913 / 4$ cents.

1885. December- - "The champion bef nnimal at Birmingham and I,ondon. England, Mr. Clement Stephens' Hereford leifer Luxury, yielded the extratordinary and hitherto unexampled proportion of $783 / 4$ ver cent. of dead meat." This is from John Coleman's Book on Cattle, Sheep and Pics of Great Britain.

1886.-Hereford steer Rudolph, Jr., exhibited by George Morgan, champion steer it the Imerican Fat Stock Show. Finst of the pony class to win the prize. His age was $\$ 83$ days and show weight 1,530 pounds.

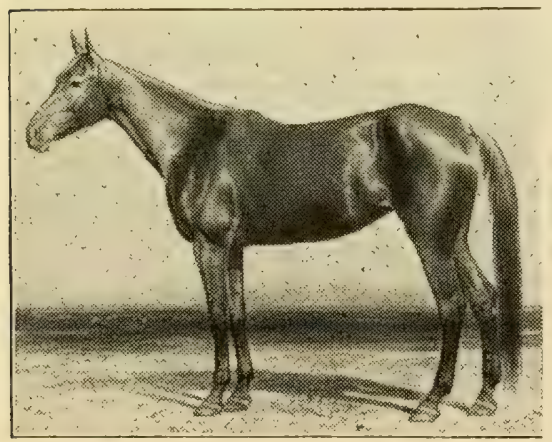

THE PEERLESS MAUD S.-On July 30 , . 885 , at Cleveland, Ohio, in her fourteenth year, MAUD s $s$ reduced the one-mile trotting record to $2: n s 3 / 4$, which reigned supreme for six years. She was driven by $W$. W. copyright photo by permission of sichreiber \& Sons.

1886.--Rev. F. von Sichluembach, of Perry, Texas. imported two bulls and two heifers of the simmenthal (Bernese) cattle breed of Switzerland. First ever brought to America.
1886, March.-Tennessee importation of jacks and jennets from Spain by J. D. \& W. H. Goodpasture and R. H. Hill.

1886. - At the Weatherford Convention of the Northwest 'Texas Cattle Raisers' Association, held in March, 1S86, there were two resulutions adorted in regard to dressed lieef, and the second one grew out of the fact that the Eastern railroads in the hands of a pool controlled by Commissioner Fink had arranged a discrimination against dressed beef. The action taken by the Texas cattlo raisers was as follows: "Resolved, That we believe it to be to the interest of the producers and consumers as fostering competition among buyers in our principal Western markets and among sellers in the Eastern markets that the rates of transportation on iressed beef and live cattle be as two to che. Resnlved, That we endorse Commissioner Fink's action in advancing the rate on dressed beef to the Eastern markets."

1886. Crmonde, the celebrated son of Ben "'Or, owned by the Duke of Westminister, ivas the victor in the English Derby, winning in 2:15 3-5 from that grand horse The Bard, which finished second

1886, August 2d.-An act of Congress was passed specially authorizing the use of harmless butter color.

1886. - Sufolk sheep first given a class in cngish Royal Agricultural Exhibitions.

1886,--The first lorkshire hogs recorded in Janada.

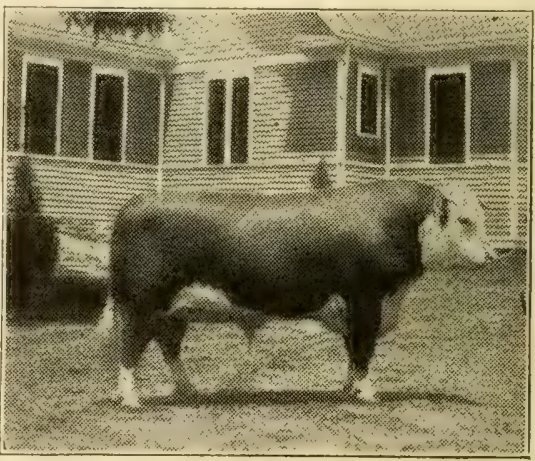

IMP. SAIISBTRY-Prize-winning Hereford bull, highiy representative of the breed. Owned by Murray Boocock, of Keswick, Alliemarle county, Va.

1886.-Highest price for middling upland cotion on New York market: Market below in ceris, for the first time in forty-four years. Highest price of the year, $99-16$ cents; lowest, \& 13-16 cents per pound.

1886.-Mr. F. Roeding, banker, of - San Francisco and proprietor of Fancher Creek Nurseries of Fresno, sent his foreman, C. S. West, to Smyrna, and was successful in obtaining good eutings of the Smyrna figs; most important step towards establishing this industry in the United States.

1886. May,-At Iatonia Race Track, Kentucky, the mile and one-sixteenth hurdle race recoril of $1: 591 / 4$ was made by the horse Judge Jackson, a son of Buckden.

1886. August 29 th.-Winslow, a son of the great Ten Broeck, made a mile and one-cighth over hurdles at the Westside Track, Chicago, in $2: 023 / 4$.

1886.--Lérry cattle from Ireland imported into the United States by Mr. Edward Kemp, of Rumsen Neck, N. J.

1886. - First volume of American Aberdeen-Angus Cattle liecord issued.

1886.-Lowest whent, in October, $693 / 8$ cents: highest, in January, $843 / 4$ cents.

1887.-Daisy D. and Silver Tail, the former by Black Steer, the other by Tempest, Jr., paced a mile as a team in $2: 181 / 2$. It was not extremely fast, but fast, considering the period. 
188\%.-Mr: Abington's Merry Ifampton, hy Iampton, proved the winner of the English Werly in $2: 43$, The Baron finishing second.

$188 \%$, May 1st.-In this month were de livered at Coolidge, Kas, and Itamar, Colo, 1,035 Ifereford, Shorthorn and AberieenIngus bulls, contracted by C. C. Camphell and T. J. Bunton to J. V. Farwell \& Co., Syndicate in the Panhandle of the Capital largest delivery of its kind in history.

188\%.-Mr. Cohb Gavitt, of Evergreen Park, near Ashley, Ohio, imported three Shetland ponies bought of the Marquis of Londonderry.

188\%, Tune-Live Stock Brecters' Direetory of the liniter States and Canada published by Philip H. Hale, of St. Louis, Mo.

188\%.-Importation of Simmenthal cattlo to this country by John Dick, of Quincy, III.

188\%,-F. A. Thomas, of Chicago, and Mr. Parker Farle, of Cobrlen. III., revolutionized the fresh fruit transportation by shipments 10 all parts of the United States.

188\%, June 21st.-In a lurdle race at Sheepshcad Bay, N, Y. Buckra, an aged horse by Buckden, made the fast recoril for two and a ruarter miles of $4: 26$. He carried $16 \mathrm{~S}$ pounds for this performance.

188\%--Johnston, the great son of Joe

Bassett, dam Cary mare, by Ned Forrest

placed the pacing record to wagon

$14 \%$. This was in a conmetitive race.

1887.-D. M. Moniger's Dr, Glick, Short horn Ateer, champion at American Fat Stock show.

188\%, July 3d.-Notable shipment of a carload of tomatoes from Humboldt, Tennessee, i) W. R. Rea, and consigned to Charles kichardson, of New York City. Practical commenrement of truck farming in Test Tennessee.

188\%. September-First car-load of Colorado celery shipped Last by C. T. Fort from Denver, Colo.

188\%.-American Essex Association incorforated in Illinois.

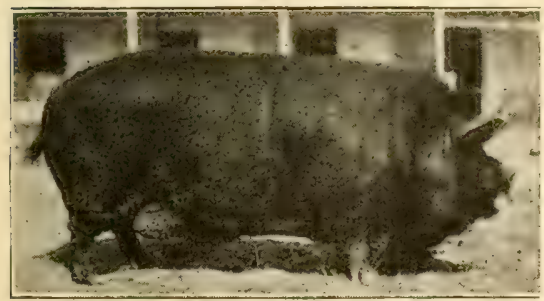

ESSLX BOAR-MODEL JIM, 1,0\$1. First prize and sweepstakes winner at the St. Louis Fair, both years; 1901 and 1302: also winrer of many other first prizes. Never defeated in the show ring. Bred and owned iy Peter Miller \& Son, of Belleville, Ill.

188\% November 1st.-Opening of the sioux City stock rards of Iowa for business. President and Treasurer, D, T. Hedges: Vice-President, James \&. Booge: Secretary, Ed. Hankinson. 'These three with A. S. Garcetson and W. V. Hedges constituted the Board of Directors.

188\%-Galloway steer, winner at Smithfield Show, weishing 2,464 pounds.

188\%.--Introduction of commercially valuable incubators for artificial hatching lates fron this year.

1887.-Lowest wheat, in August, $663 \%$ cents; highest, in June, $94^{3 / 4}$ cents.

188\%. - In this year the experiment of disposing of California fruit at auetion was tried in New York by Messrs. Sgobel Fruit Union, and the result proved favorable.

1888. - The Aberdeen-Angus steer, Dot, exhibited liy Mr. Imboden, champion at the American Fat Stock Show. Age, 863 days, and show weight, $1,515^{\circ}$ pounds.
1888, May 5th.-The Peninsula and Orlental Company's steamer "Oceanica" sailed
from Melhourne, Australia, with 500 tons of Australian apples, reaching London June I"th, mostly in sound condition. Beginning of desan commercial refrigeration.

1888. - Hellriegel, a German chemist and investigator, announced that the nodules on the leguminous plants were colonies of acteria, and that their work was to take up nitrogen from the air and convert it into plant food.

1888. - In this year the White Wyamdotte 1 merican poultry Associntion. The credit of their origin is given to Geo. W. Towle, of Truxton, N. Y, and B. M. Briges, of Vyandale, N.

1888, Dugust 21st.-The record for a mile and three-sixteentlos, whlch is $2: 1$, was made by fim, a four-year-old, by Felweraft, at Saratoga, N. Y.

1888 , september $17 \mathrm{th}$.-Organization of the American IBreeders Association of Jacks and Jennets at springfield. III. President. and Jennets at springfield, Ill. President, President, Alhert Babb, of Taylorvilie, Ill. Socretary, W. H. Gondpasture, of Nashville, Tenn.; Treasurer, Major Wm. Gentry, of Edalia, Mo.

1888. - Johnston bared a mile under saddle in "'l.s hreaking" the record of $2: 143 \%$ Ohl Corbeau. Johnston's feat has never

1888.-Polled Durham cattle first recognized as a distinct breed by the Ohio Cen\& Clawson and Cantain W. S. Miller.

1888. October 19th.-Sunol, a bà filly, placed the one-mile two-year-old trotting record at $2: 201 / 2$ at San Francisco.

1888.-J. I). \& IV. II. Goodpasture, of Nashville, Tenn. made the largest individual jack and jernet importation-fifty-seven

1888.-Lowest wheat, in Apris, $71^{1 / 8}$ cents: highest, in September, caused by the Hutchinson corner, \$s.00, declining io $1.04 \frac{1 / 2}{2}$ the next day.

1888.-Prof. IV. M. Hays, of the Minnesota Experiment station, began a series of sotematic wheat experiments of invaluable service to the wheat growers of the country.

1888, Yovember. - The lamb-feerling industry in Larimer county, Colorado, commenced by Bennett Bros, of Fort Collins, vurchasing 3,500 Mexican lambs, whicin they intended feeding corn at Paxton, Neb. but, being snowkund in transit, the lambs were brouaht to Fort Coliins and fed on alfalfa, with corn added to the ration later. The result was that they gained rapidly in flesh and condition and topped the Chicago market at $\$ 5.40$ per 100 pounds. By the year 1900 the lamb-feeding industry of Colorado had increased to 351,225 head in

1888. - Iron framework first used in greenhouse construction in this year and came rapidly into lise.

1888. - Ayrshire, owned by the Duke of Portland, a horse sired by Hampton, won the linglish Derby, and also incidentally established the fastest time in its history to that date, that of $2: 421-5$.

1889. - An Arkansas firm imported twentyive fine jacks and jennets from Spain. Exhibiter at the St. Louis Fair.

1889.-Dr. D. E. Salmon. Chief of the Burcau of Animal Industry, determined gation of Southern attle fever, resulting in the adoption of the tick theory as the cause of disease. The experiments were conducted by Dr L. Kilhorne.

1889. - Slorthorn steer Rigdon exhibited y Elbert \& Fall, champion at the American Fat Stock Show.

1889.-The white variety of Orpington fowls established a breed that dates from this year.

1889. - The Department of Agrículture imrorted rooted suckers of the Date Palm from Algerian Sahara and Egypt and sent them to Nery Mexico, Arizona and California. 
1889.-The Duke of Portland won the English Derby with the horse Donovan, which was sired by Galopin. The time wsa $2: 442-5$. A horse named San Miguel was

1889. - In the year 1889 the legislators of the state of Virfinia enacted a law which was intendied to shut dressed beef out from that state. The law prohibited the offering for sale of fresh meat at places 100 miles or inore distant from the places of slaughter unless it had been inspected by the local inspectors of Virginia, for which inspection the owner of the meat had to pay one cent per poind. The inspection alone amounted 10 from $\$ 6,00$ to $\$ 10.00$ per head. It was pronounced unconstitutional. This was an examp!e of state enactments passed for the nurpose of interfering with interstate commerce and more especially to please the lutchers who were trying to kill the dressed-beef trade by law.

1889.-The "Carman" peach originated from seed planted hy J. W. Stubenrauch. of Mexia, Texas. Early variety and comyaratively free from rot.

1889-Through influence of Prof. H. Ji. Van Demen, Pomologist, and Prof. C. V Riley, Fintomolorist, the United States Depitrment of Agriculture secured and distributed Cami fis cuttings from Turkey.

1889.-Benizmin Harrison, President of the United itates, and served four years.

1889.--Union Cold Storage Company of Chicago, first Western establishment to offer mechanical refrigeration for general storage, apples heing the dirst fruit stored.

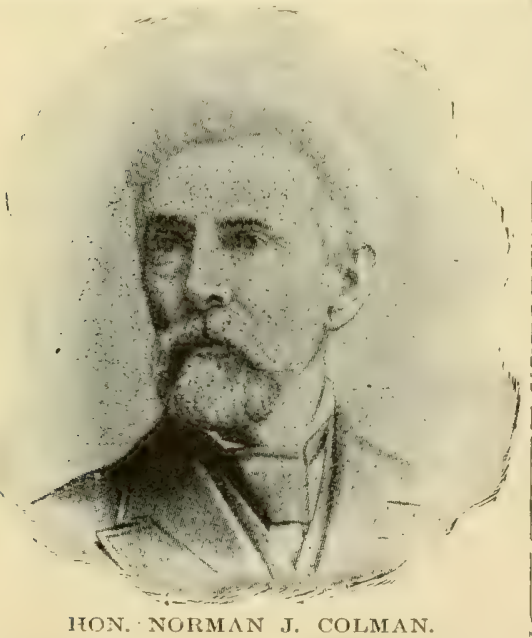

1889, Fehruary 11 th-Hon. Norman J. Colman, of Missouri, eclitor and proprietor of the Iiural World, appointed the first tecretary of Agrieulture by President Grover Cleveland. Previously the highest ofticer of the Ag:icultural Department was Commissioner.

1899.-Lowest wheat, in June, $751 / 2$ cents; highest, in Fehruary, $\$ 1.0 \mathrm{~s} \%$.

1889, August 25th. -Death of Henry Shaw, Born in Sheflelr. Fingland, July 24, 1900 . Ife gave the famous Shaw's Botanical Garien and Tower Grove Park to the city nf st. J,ouis.

1889. A ugust 30 th. - The fastest half mile on the running turf was made by Geraldine at New York in $0: 46$. It was on a straight course, and she was carrying 122 ipounds. Feraldine was by Grinstead, and four years old when this record was made.

1889, October 11th.-At Terre Haute, Ind., Axtell trots a mile in $2: 12$, establish. ing three-year-old and stallion record.

18:9, November 1th - Ameriean Folled Jurham Breeders' Association organized. President, Wrin. W. Crane, of Tippecanoe City, Ohio; Secretary, A. E. Burleigh, of Mazon, III.
1889.-Luke M. Emerson, of Bowling Green, Mo., imported Catalonian , iacks.

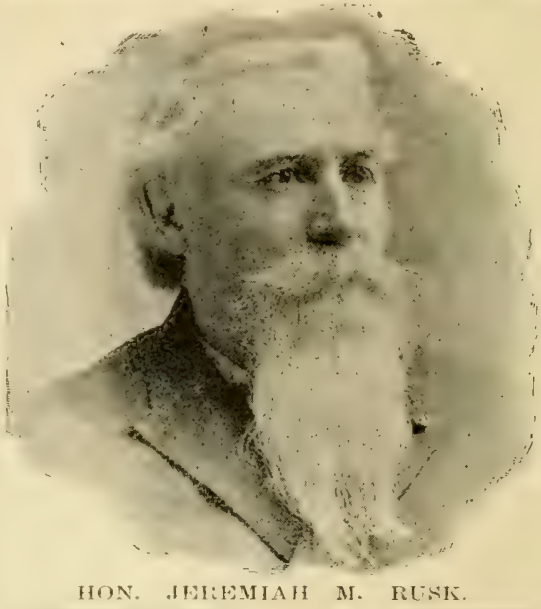

1889,--Joremia il M. Fusk, of Wisconsin, iecretary of Agriculture under Presiden Benjamin Harrison

1889. The American Agriculturist corn coutest for the largest yield of corn on one mensured acre. Grand prize won by Zachariah Jordan Drake, of Marlboro county, South Carolina, who grew 255 bushels of helleri corn or 239 bushels crib-cured corn at a high net cust of 44 cents per bushel. Secund prize won by Alfred Rose, of Yates county. New York, who grew 213 bushels of shelled corn or 191 bushels of crib-cured corn it a cost of 16 cents per bushel. Third prize won hy George Gartner, of Pawnee county, Nebraska, who grew 171 bushels of shelled corn or 151 hushels of chib-cured corn at a cost of 17 cents i)er bushel.

1890.-The census of this year enumerated! $5: 36$ serel farms in the United States, containing $169,8.50$ acres, of which 96,567 acres were actually producing seed crops.

1890. - Silver Mine, a standard variety of white corn, originated in this year by $J, H$ Bearley, of Sibley, Il].

1890, February 20th. The National Live stock Reporter established at the St. Louis National Stock Yards by Philip H. Hale.

1890.-Center of United States population, twenty miles east of Columbus, Ind.

1890.-The Babcock Cream Tester invented by Dr. $S$. M Babcock, of Madison, Wis., ind generously given over to public use and benefit without charge.

1890.-The United States Census reported 4.564,641 farms in the United states, an increase of 555,734 in ten years.

1890. - Dispersion of the Cruickshank Shorthorns, the breeder being 82 years old.

1890.--Great improvement in cream separators by baron von Eechtoldsheim, of Germany, Hand separator made possible by Alpha disc system.

1890. - The Jolstein cow, Pauline Paul, owned l,y J. B. Dutcher \& Son, of Pawling, N. Y., reported as having made 1,153 and 63 64 ths pounds of butter in one year.

1890, May 1st. First alfalfa sown on Woodland Farm, Ohio, by Joseph E. Wing. Really the beginning of successful alfalfa culture east of the Missouri river.

1890.--Village postal delivery recommended by Postmaster-General Wanamaker, a forerunner of Rural Free Delivery.

1890, July 8 th, - The record for seveneighths of a mile, running over a straight colrse, was placed by Bell B., a five yearold, at $1: 23 \%$, at Monmouth Park, with 103 pounds up. Bella B. Was by Enquirer.

1890.-Iouisiana became first in rank $c f$ rice-growing states, displacing South Caro-
linit. 
1890. - Illinois State Fair at Peoria. Great contest of champion shorthorn bulls Cup Betrer, Phenomenon, Goldstick and Younf Abhotsburn, the latter the victor: weighed $\because 800$ pounds; owned by T. S. Moberly, of Kentucky.

1890.- The English Derby was won by Sit* James Miller's Sanfoin, by Springtield. Thero were only eight starters, and LeNord was second. The time was $2491 / 4$.

1890, July $17 \mathrm{th}$, - Banquet the mighty race horse, placed the record for the lyeriby distance (a mile and a quarter) at $2: 0: \frac{1}{2}$ at Monmouth lark over a straight course. Banquet was by Imported Raymond d'Or, ind was one of the preatest horses that exer ilied.

1890. Ausust 20 th. - The fastest horsas ruming recorl ior a quarter of a mile was marle i.y Tol, Wade, a four-year-old, at Buite, Mont. The time was $0: 21 \frac{1}{4}$

1890. -Center of the number of farms in the I'nited States, eighty-two miles south by west of Indianapolis, in Washington county, Intiana.

1890.- The Shorthorn steer Nonesuch, eyhibited by W. H. Renick, champion at the Chirago Fat Stock sinow

1890, $\Delta$ ugust 28th. - The famous ruming horse salvatur made the phenomenal mile record of $1: 3.31 / 2$ at Monmouth Park over a straight course in a race against time Salvator was by Imported Prince Charlif When he performed this feat he was a four year-oid and carried 110 pounds.

1890,-I.owest wheat, in February, 711 cents; highest, in August, $\$ 1.0 \mathrm{~S}^{1}$

1890.- - Swine ire Ireland, 1,570,366 head, the largest number known in that country

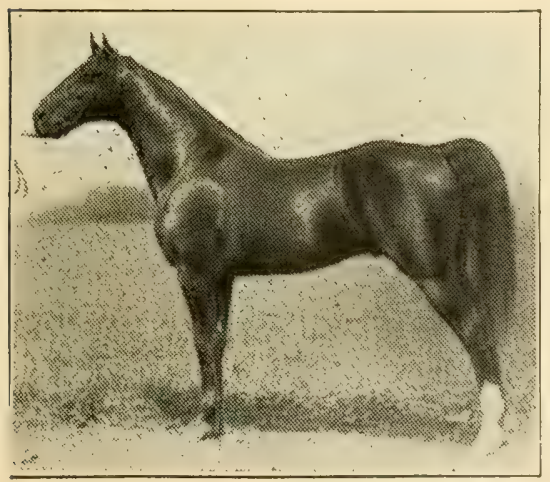

PRX PFAVTNE-Saddle stallion. Owner by Dr. IT. L. Hnckaday, of Richmond, Ky. ivinner at Lnuistille ( $\mathrm{hy}$.) State Fair. Representative imerican saddle horse.

1891. The American (formerly National) Saddle Horsa Breder's Association organized at Touisville, $K \mathrm{~K}_{\text {.. }}$ and issued the first volume of the American Sadale Horse Register tho year following.

1891.-Allerton. one of the greatest rase horses and sires of extreme speed in the history of the trotting turf, was sent a mile froting to wagon, and set the trotting mark at 2:15. He was sired by Jay Birci, and his dam was Gussie Wilkes, by Mambrino Boy.

18:1. - In this yar the unique performance of three horses trotting a mile abreast was marle in the fast time of $2: 14$. The horses were Relle Hamlin bay mare clobe, bay gelding; and Justina, bay mare; all by Almont, Jr.

1891.-Caprain S. F. Fourtain. United States Cavalry, with mounted detachment, rode eighty-four miles in eight hours, a record of horse endurance.

1891.-The Berry Farmer, published by B. F. Smith at Lawrence, Kansas, one of the early fruit publications of the TVest. Short-lived but valuable.
1891. June 23d Kingston, the son of tho reat spend-hrift carrying 134 pounds, net the mark for the ruturity Course, which is 170 feet less than three-fourths of a mile, in 1:08. The nerformance was madc at coney Islanat. N.

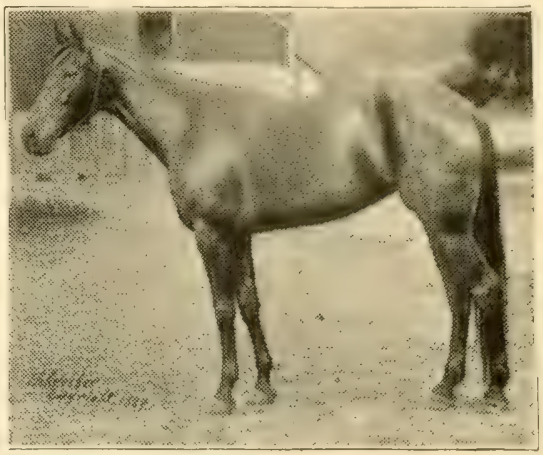

ST:NOT, $2: A \$ 1 / 4$, hy Electioncer

1891. -Sunol, bay mare by Electioneer, dam Waxana, by Ceneral Benton, became champion trotter. clippinf a half second off the tedueing the worla's mark to $2: 0814$. Tho vecord was made at Stockton. Calif, where she was driven by Charley Marvin.

1891.-Mr. James Shinn, of Niles, Calif., ohtained the first specimens of Blastophaga, the fin fertilizing insect from syria.

1891, August 1 ifth. The first horse to run three-cighths of a mile in $0: 34$ on the Amerthe recors frision, a four-year-old, and The record Weord was later equaled on July $22 \mathrm{~d}$. 1s?f hy Reris., an aged horse, carrying 122 pounds, at Butte. Mont., and thus held jointly by the tw. .

1891.- The two-year-old Hereford steer Hickorynut, exhibited by IV. S. Van Natta, champion at the American Fat Stock Show At 354 days his weisht was 1,629 pounds.

1891. Sentember $3 \mathrm{~d}$ - At Independence, lowa. Direct, wlack horse by Director, paces in $2: 06$, making world's record.

1891. - The Blanche Ferry, a descendant of the Painted l,aily, lirst valuable variety of the modern weet pea, introduced by Amerian seedsmen.

1891. - The Iargest week's receipts of cattle any manket were recorded at chicago during the week ending September 19th, the total being 95,521 head.

1891.- - First two-billion-bushel corn erop in the Luited Stales; oflicially 2,060,154,0100 t) ushels.

1891. November. At the Chicago Dairs Show the Brown swiss cow Brienz, owned by Abe Bourquin, of Nokomis, Ill, made 9.32 pounds of butter-fat in three days, being the largest yield in public competition.

1891.-Three-sear-old beef cattle aroppei from classes of the American Fat sitor:k

1891.--Lowest wheat, in July, 85 cents: hishest, in - ipril, $\$ 1.16$.

1891.-A horse named The Common, by Isnnomy, owned by Sir F, Johnstone, was the winner of the cinglish Derby. The time marle, $2: 56 \quad 4-5$, was the second slowest in it: history. Gouverneur ran second.

1891- - The pacer Joe Jefferson made the fastest recoul for tour miles in harness, his time being in:10. This record was made against time.

1891. - The Smyrna fly first hand pollinated hy Dr. Fisen at Niles, Calif.

1891, November 10 th. At Stockton, Calif, Arion trots in $2: 10^{3 / 4}$, the world's two-searold recurd.

1891, November 17th.-Palo Alto establishes a world's stallion record by trotting a mile in $2: \cap 5 \%$ 
1891, December 9th. - At the St. Louis National Stock Yards first exhibition of carloats of live stock for prizes in pens of a public stock yard. Premiums paid by Philip H. Hale, publisher National Live Stock Reporter.

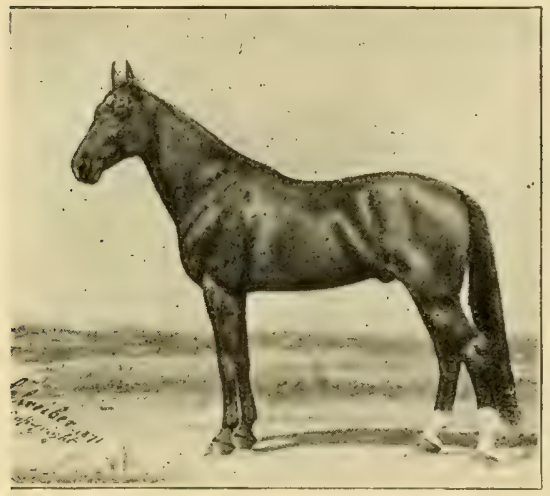

HAPPY MEDIUM, $2: 321 / 2-T R O T T I N G$ SIRE. By Hambletonian. Sire of Nancy Hanks, 2:04; Riley Medium, $2: 101 / 4$; Maxie Cobb, $2: 131 / 2$; and many others in the $2: 15$ list. From copyright photo by permission of Schreiber \& Sons, of Philadelphia. Pa.

189:, Fehruary 4th.-German, Hanoverian and Oldenburg Coach Horse Association of Anuerica bert of Greeley. Iowa: Secretary, Jeptha Crouch, of I,afayette. Ind.

1392. April 27th-First car-load of tomatoes from fiorida shipped to England.

1892. June 5th.-Sir John, by Sir Modrea took a record of $2: 14 \frac{1 / 4}{4}$ for a mile and fivesixteenths over the New York Jockey Club Course.

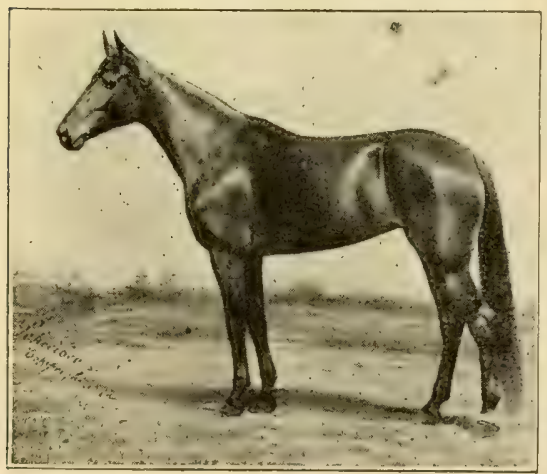

NANCY HANKS。 2:04.

189?.-Nancy Hanks, the famous daughter of Hanpy Medium and Nancy Lee, by Dictator. jumped into fame by lowering the trotting resord to 2:07 1/4. The record was made at Chicago, 111., August $17 \mathrm{th}$, Budd Doble drivinf. It was an attempt against time. On the last day of the same month, at Independence, Iowa, she performed the phenomenal feat of taking two more full seconds off the record, reducing it to $2: 051 / 4$. A month later, at Terre Haute, Ind., driven by Doble, she brought the mark down to $2: 04$, her best record. Thus from August 17th to September $28 t h$, a space of forty-one days, this thrice-crowned champion cut $4 \frac{1}{4}$ seconds from the world's great record. She was inindeed a marvel. The Bike Sulky dates from this time in trotting and paeing races.
1892.-.-Mr. Geo. C. Roedding, of San Franisco Calif secured consigmments of tigs containing Blastophagas (the fig fertilizing insect) from Smyrna in Asia.

189:- - American pears, plums, peaches and oranges were first exported commercially to Finsland.

1892. - Largest receipts of cattle in one year at the Union stock Yards, Chicago, $, 571,796$ head.

1892.-Sheep in Irelani, 4,827,777, the argest numlier known in that country.

189. July 21st. Maid Marian, in her three-ycar-old form, set the mile and twenty vards ruming record at $1: 40$ at Washington l'ark, Chicago.

18:2, September $22 \mathrm{~d} \rightarrow \mathrm{At}$ providence, $\mathrm{R}, \mathrm{I}$, Belle Hamlin and Honest George trotted a mile av a team against time, and brought the record to $2: 121 / 1$, beating the previous record of $2: 13$, made in 1891 by Belle Hamlin and Justina

189:- - Potts \& Son's Shorthorn steer King. champion at Stock Yards Fat Stock Show, Chicago.

189:3 Septeniber-I - Irgest receints of eattlo in one montn at the Union Stock Yards, chicaro, 385, tis heak.

189.3.-Sir Hugro, sired by TVisdom and ouved by Lord Bradford, took the English berby from a field of thirteen starters. The ime, $2: 44$, was fair. LaFleche was second.

1893.-Grover Cleveland, 'President of the United states, his second term, serving four years.

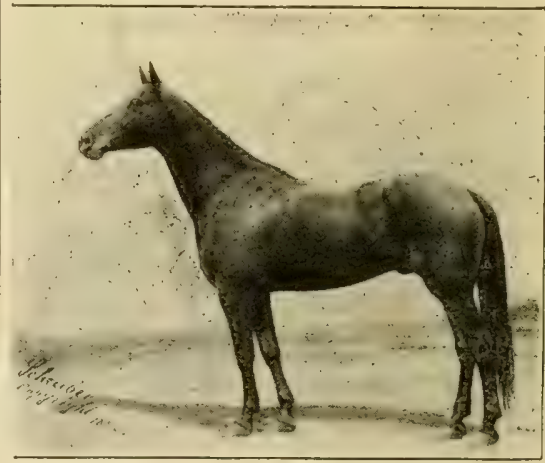

MASCOT, 2:04-PACING GEIDING. In the year 1892 for the first time a trotter. Nancy Fanks, and a pacer, MASCOT, divided the honor of being the fastest light-harness performer.

1892. November sth.-Direct vaces a milo in 2.0 .16 making a world's stallion record. This at Columbus, Tenn.

189:, November 10th.-Western Holsteinliriesian Asmeiation incorporated. President, M E. Moore of Cameron Mo: Vice-Presirent. $F$ T Irwin of Richfield, Minn. Treasurer, .T. B, Zinn, of Topeka, Kas.; Secretary W. F. Whitney, of Marshall, Mo.

189:- Lowest wheat, in October, $691 \%$ cents: nighest, $91 \frac{3}{4}$ cents, in February.

1893.-Columbian Exposition Shorthorn contest. Champion bull, any age, Colonel $T$. S. Moberley's Young Abbotsburn; champion female, J. G. Robbins \& Sons' Gay Mary.

1893. - Early in this year California made her first attempt to export fruit to England under the general management of the Earl Trust Company. The orange growers of Azisa, Duarte and Covina, Los Angeles couniy, contributed the fruit. One car, containing 290 boxes, left New York on the steamer Teutonic on March $8 \mathrm{th}$, consigned to L. Connolly \& Co., of Liverpool. The consignment was a success. The authority of this statement is Balley's Annals of Horticulture.

1893.-Lowest wheat, in July, $54 \frac{3 / 8}{8}$ cents; highest, in April, 88 cents. 
18(3). - Nightingale, by Mambrino King, fam by Hambletonian, 572, placed the throemile trotting recoril at $6: 551 / 2$

189:3-Maseot, bay gelding, by Deceive divided honors with the trotting mare Nancy Hanks by reducing the ommmile paring record to $z: 0 t$. This at T'erre Haute, Ind., Septemker 1 ith.

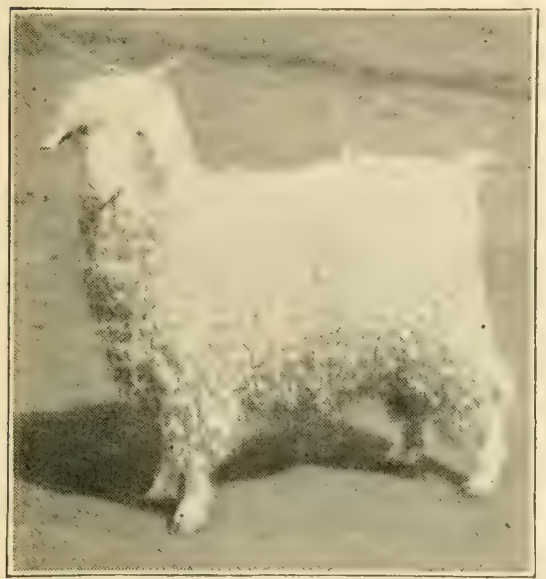

Prize-winning Angoric goat

1893.--Dr. C. P. Bailey, of San Jose, Calif., imported two ingora bucks from South Africa.

1893.-Champion beef animal at Columbian Fxposition, the shorthorn beef steer Cup Bearer, exhibited by Milton E. Jones, of Williamsville, Ill.

1893.-Isinglass, by Isonomy, orrned by Wr H. McCalmont, won the English Ierly in $2: 43$,

1843. March 10th-... First bottle of "certifield milk" delivered by stephen Francisco of Essex county, New Jersey.

1893.-F. J. Merriam, pioneer market gardener of Georcia, commenced operations in this year near Atianta.

1893, July 4th. - It Kirkwoot, Del., Ayres P.. a chestnut gelaing by Prosper Merrimee, trotter a mile against time alongside of a ruming mate in $2: 03 \frac{3}{2}$.

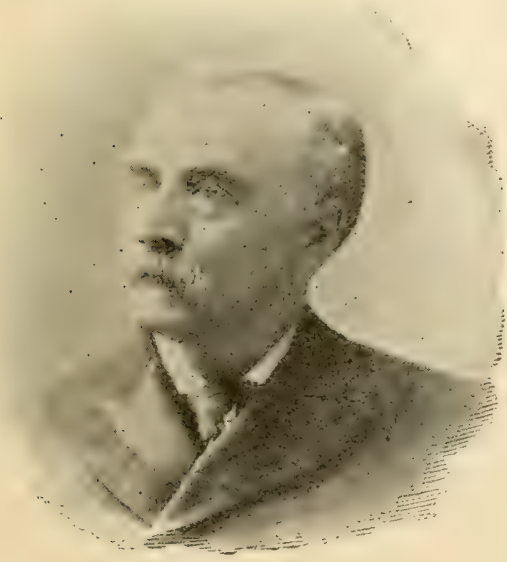

HON, J, STERLING MORTON.

1893.--J. Sterling Morton, Secretary of Agriculture during second term of President Cleveland.
1893.-Ameriesn Yorkshire Askociation ardaniked. Jon. IV. M. Jifgett, President; and Minjor A. C. Wilcox, Secretary.

189:3, Septomber 15th.-Flyinis J1h, bay waldine loy Aigona, waces a mile in $2: 04$ at chicalgo, equaling the world's record. This at a performance abainst time.

1893, Oetoher 17th. - Fantasy, bay mare by chimes, trots in $2: 08 x_{1}$ at Nashville, Tenn., estatilishing the world's record for threevear-old lilly.

189:, Octolier 18th.-At Nashville, Tenn., i) irecturn, liv Director, trots in $2: 051 \%$ stablishing a world's four-year-old record.

18!3.--Tin stan Jove scale, the most damenemy (i) fruit trees, discovered in New Jersey, it was hrourht from california 11) non nurepry stock

1893- - It luenburg, Mass, Juther Bur. ouk orisinited th: famous burbank potato. this first impurtont success in plant im rovemivit.

18:4.--Cotton boll wovil first came to uotice of Jemartuent of A criculture as in ortant enemy of cotton in Fexas.

18: 1 . July 5th. - The fastent time for a mile ame thren-eightis was matle by sabine, by inssington, at Washington Park, Chicagu. 1894 . A 1 gust. First car of crated eabbage hiplued from Denver, Colo., by C. 'T. Fort.

18:4, Sentember 1:3h.-Robert $\boldsymbol{J}$ a bay relding by Hartfork, establishes world's mile pacing record in $2: 01 \frac{1}{2}$ at Terre Haute, Indiana.

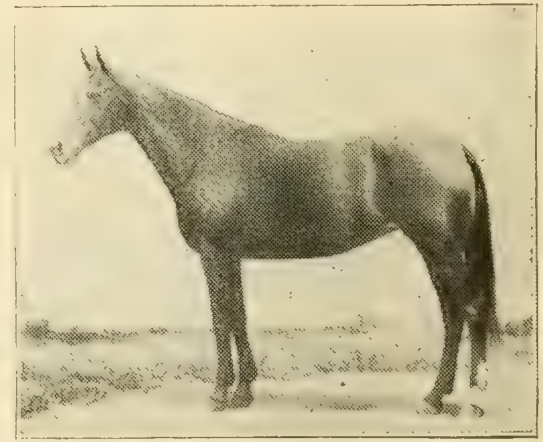

ALIX, $2: 0: 3,1$

1894.-Division of soils organized in the United States Weather Bureau by executive United States Wheather Bureau by executis order, afteris.

1894 . The rastest team record in a trotting race was placed at $2: 511 / 1$ by Sally Simmons, a daushter of Simmons, and Sally Adams, by John Burdine, and Roseleaf, mare hy Goldleaf, dam Florence B., by At tantic.

1891. September 19th. - Alix, bay mare, by Patroniare dam by Attorney, placed the mile trotting match at $2: 03 \frac{3}{4}$ at Galesburg, driven by Andy MeDowell.

1894, September 27th. - Abdell, bay colt, by Adverticer, establishes vearling world's troting record for one mile in $2: 23$ at Stocktan, California.

1894.- The system of putting up cotton in crlindrical hales started at Waco, Texas.

1891, Detnber 3d.-At Chillicothe, Ohio, Flying Jib, the famous pacer, hitched with a running mate, went the mile in the re markably fast time of $1: 5 \mathrm{~S} 1 / 4$, the fastest mile negotiated to that time by a harness horse: but the momentum given by the runner takes some merit from the perform. ance. This style of racing is not now in vogue.

1894. October 9th.-Maid Marian, the fouryear-old daughter of Imported Great Tom, galloped five-eighths of a mile over the New York (straight) Course in $0: 56 \%$, breaking all records 
1894. - At the Dairy Show in England in this year a pair of Single-comb Bufl Orpington fowls were exhibited by Mr. Cook, of Tower House, Orpington, the originator of the breed.

1894.-Iowest No. 2 cash wheat in Septemver, 50 cents; highest, in April, 651/4 cents.

1894,-American Agriculturist chanred from a monthly to a weekly publication.

1894.-Champion beef animal at American Fat Stock Show, the Shorthorn steer "Whiskers," exhibited by J. H. Potts \& Sons. Weight at 1,048 days, 1,776 pounds.

1894.-.-. Whie Cupid, a famous variety of the swet wea, discovered as a chance sport on the seed firms of C. C. Morse \& Co. of California.

1894.-Gilbert H, Hicks placed in charge of first govermment laboratory for testing seerls.

1894.--Tnrd Roseberry won the Finglish Merby with Ladas, by Hampton, in 2:45 4-5. The field was the smallest in the history of the classic, there being only seven starters.

1895. - The trotting recorl for three miles of $7: 161 / 2$ in a race, was macle by Fairy wood, a bay gelding by Milbourne, dam by Fairy Gift.

1895. February 11 th.-Largest receipts of hodrs in one day at the union stock yards, Chicago, 74,551 head.

189\%. Galloway cattle shown at Birmingriain and Snithfield.

1895. April 5th.-Ilorse and mule marlict opened at the St. Jouis National Stock Yards by John Kirk and T. T. Ruby, com mission salesmen, and A. Heiman, mule dealer. John kirk held the first auction.

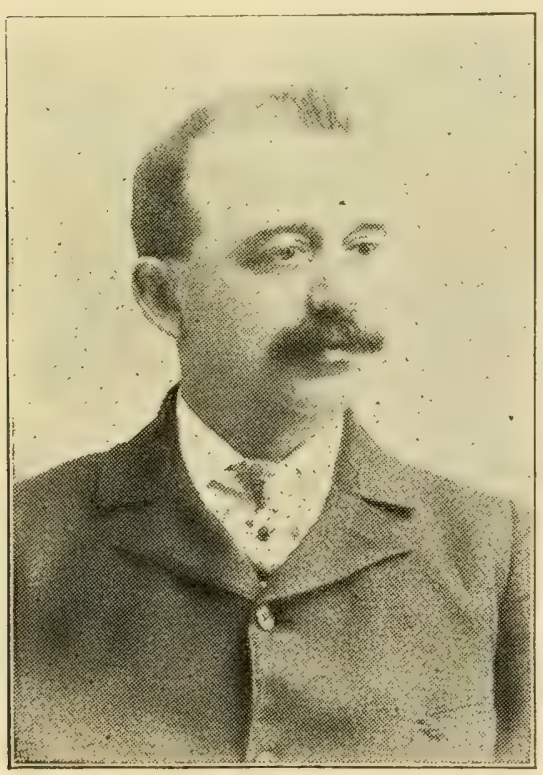

MR. A, HEIMAN, mule deaier, who-as the only operator in the yards at the tirne - established the great modern mule market at the St. Louis National Stock Yards.

1895, July 24th. -The Sioux City Stock Yards passed into possession of the Sioux City Stock Yards Company. Col. I. C. Flston, President, of Crawfordsville, Ind. Nashua, N. H. Mr. F. L Eaton, Secretary and Treasurer, of Sioux City, Iowa.; Mr. H. P. Chesley, General Manager, of sioux City, Iowa. The Board of Directors included Messns. John Fillis, of Kewanee, Ill.; Joseph C. Head, of Latrobe, Pa.; Wm. Reynolds, of Marblehead, Mass.; and Michael Cudahy, of

Chicago, Itl
1895, September 10th.-The steamship Southern Cross, 5,050 tons register, arrived th I,ondion from Sydney, Australia, laden with cattle, sheep and horses. 'This was the first large attle shipment of live animals from the Antaretic eontinent. The ship's voyage was by way of Monteviclio, in oraer to avoid the heat of the Red Sea. The ship ment consisted of 550 cattle, $4 \mathrm{SS}$ sheep and 29 horses, all in charge of thirty men. The deaths er route were fifty-two cattle. eighty-two sheep and one horse. The cost of transportation, feed and attendance was \$68.55 per head for honses and cattle and $\$ 6.90$ per hear for sheep. The shipment was not a financial success.

1895.- Lowest wheat, in January, $483 /$ cents, ineing the lowest on record; highest of the year, in May, S5 $3 / 8$ cents.

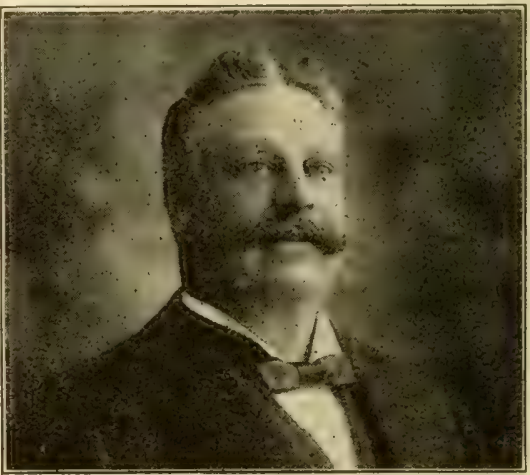

MR. TIIOS.: W. CROUCH, inule dealer and representative of the old Broadway Mule Market of St. Louis, who contracted for the removal of the entire mule trade of the city of St. I.ouis to the National Stock Yards.

1896, February 3d.-The old Broadway horse and mule marliet at St. Louis, which, heginnins at a period around 1853, had become the greatest in the world was totally abandoned, all of the remaining firms removing to the St. Louis National Stock Yards, where the modern St. I,ouis horse and mule market had previously been estabished. The firms which mover across the river were the Western Sale Stables Company: Maxivel: \& Crouch Mule Company: Snarks Bros, charles Cahn \& Son: Jacques, Levy \& Ce.; and J. D. Guyton \& Co. That day's receipts were 1,372 head.

1896,--Tord Roseberry won the Enslish Derby for the second time with Sir Tisto, son of Barcaldine. Time, $2: 43 \quad 2-5$.

1896. This year the maximum crop of Sea Island cotton in the United States xvar grown, there being 103,516 bales reported to the Inited States government as the crop of $1896,-97$.

1896 - In tinis year the record of $2: 30$ for a mile twas marle by a four-in-hand of trotters. consisting of Damiana a chestrut mare Belnut, a chestnut gelding; and Maud $V$. and Nutspra, also chestnut mares; all sired by Nutmeg.

1896. March 24th- - Patent for a single-dise plow granted to C. A Hardy and manufactured by the Texas Disc Plow Co.

1896.- - t Madison Square Garden Live Stock Show the Hercford steer "Jack," yearling, was grand champion.

1896, June,-W'Top native cattle at Chicago sold at $\$ 4.65$ per 100 pounds, the lowest in about twenty-five years.

1896.--Mr. Arnold Cooper, of Richmond, Natal, South Africa, noticed grasshoppers to be dying from fungus lisease. The knowledge since used for destruotion of the grasshopper pest.

1896. - The Prince of Wales' entry, Persimmon, a son of St. Simon, won the Englisl Derby from a field of eleven in the fast lime of $2: 42$, St. Frusquin running second. 
1896, June 6th. The use of harmless coloring matter in the manufacture of cheese was specially authorized by law.

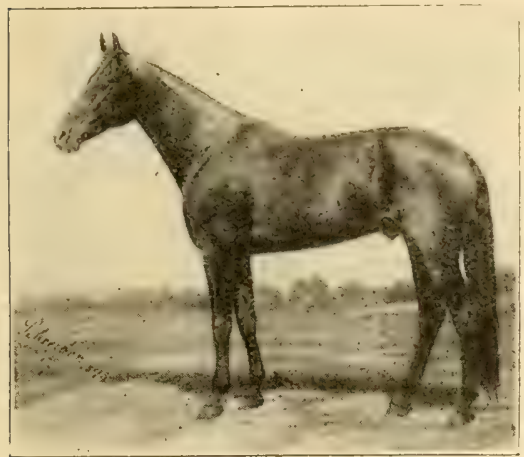

JOHN F. GENTTRY, 2:11:1!,

1896, September "th th...John $R$. Gentry hay horse by Ashland Wilkes, paces a milo in $2: 001 / 2$, establishing a world's record.

1896.-Buff Orpington fowls establislied as a distinct family in this year.

1896.--Vegetable canning on commercial hasis. Record for United States and Canada, $3,511,1 \mathrm{~s}$ s cases of tomatoes and $2,676,515$ cases of canned corn. Each case contained two dozen standard cans.

1896, netober 1st.-Iirst liural Free Delivery rostal Routes established in this country at Halltown, Uvilla and Charlestown,
W. Va. Hon. Wm. L. Wilson was PostmasterGeneral.

1896.-Towent wheat, in June, $585 / 5$ cents; highest, in November, $94 \mathrm{j} / \mathrm{s}$ cents.

1897 , January 1st. The West I'hiladelphia Stock lard Company succeeded the old Stock Yard Company, which had been 11 husiness since 1876 . Officers of the new company: Thos, B. Shriver, President; and Joseph M. Ifarlan, Secretary and Treasurer. Board of Directors-Thos. B. Shriver, S. IV. Allerton, D. H. Sherman, D. B. Martin, A. M. Fuller, TV. M. Fuller and Joseph $M$ Harlan.

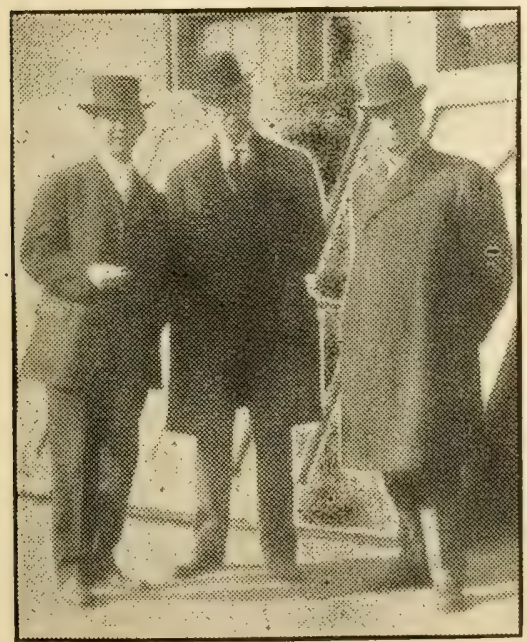

I. J. SEARCY on left, JOSEPH MAXWELL in center, and FRANK SLOAN on the right, three of the pioneers of the St. Louis horse and mule market.
1897.- At the meeting of the Assoication of Igricultural Colleges and Fivperiment fitations a committee was anpointed, consisting of Professors Jenkins, Card. Lazenby, McCarthy and Mr. Gilbert H. Hicks, to dratv up rules and regulations for seed testing

18!) - Galtee mare, owned by $\boldsymbol{J}$. Gubhins, captured the Muglish lerby in $2: 44$, Velas quez being second. The winner was sired by Kendal, a horse of no great prominence.

189\%.- - W $\mathrm{Wm}$. Mekinley, I'resident of the United fitates, servine four years and unti] re-electerl. when he died at the hands of the

1897.-New era in rice culture. "Providence" rice dependent upon rainfall and hand plowing, succeeled by irrigation and horough machinery methois.

189\%-James TIilson, of fowa, Secretary of Irriculture,aploointed by President Mckinley.

1897 -..First commercial seed testing laboratory in the United States established by $\mathbf{M r}$. Frank Sempers at Blythedale, Md.

1897.-At the American Fat Stock Show the Iereford stere "Jack" was champion; a Lwo-year-old, weighing 1,830 pounds.

189\%, May 26th.-Handpress, the remarkable son of Hanover, in his two-year-old form, with 100 nounds up, set the four-andone-half furlong record at $0: 52$ at the New York. Jockey Club meeting.

189\%.-Rex N Blaxland imported pure-bred mora coats into New South Wales, Australia. from the island of Tasmania-the fioneer finck of the modern Angora industry in New South Wales.

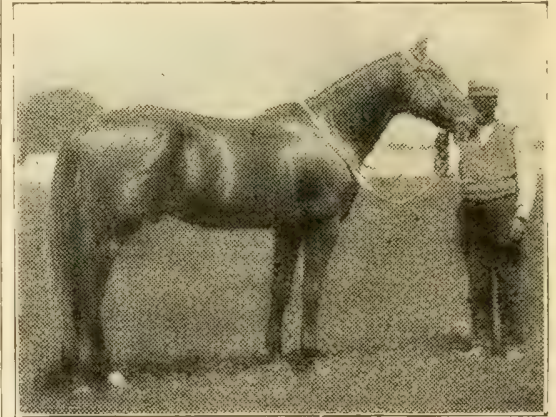

BROTN HAL, 2:12\%-Son of old Tom Hal. Sire of Star Fointer, 1:591/4, and many other great pacers. From photograph by Schreiner. BROWN HAL was foaled in $187 !$ and bred by $i 2, H$. Mone, of Culleoka. Tenn.

189\%. Seed and plant introduetion first undertikien by the Department of Agriculture on systematic scale.

189\%, June-Fxperiments in pasteurization of cream for the jurpose of improving the keeping qualities of butter were conducted at Hesston Creamery. Newton. Kansas, by T. H. Monrad, Special Agent Dairy Division, Initer States Bureau of Animal Industry. Jesults favorable to pasteurization, but not clearly and distinctly so.

189\%. July. - At this time the United States Denartment of Agriculture first besan to distribute vaccine virus for the prevention of blackles in cattle. Age for inoculation. six to twenty-four months,

1897.-I,owest wheat, in April, 64 t/ cents; kighest of the year, in December, $\$ 1.09$

189\%. Octoler Sth.-At Glen Falls, N. Y.. John F. Gentry and Robert J., paeing as a feam, against time, set the mark at $2: 03$.

$199 \%$ December 1 st.-First auction sale of pura-bred lugs (Berkshires) at the St.Louis National Stock Yards.

$189 \%$, December 27th-First meeting of the american Tamworlh swine lecord Assocision. President, B. F Miller, of Flini Iion. President, B. F. Miller, of Flin,, also of Flint, Mich.; Directors, F. P. Smith. F. II. Rankin and J. J. Carton. 
1897. - Star Pointer, lay horse, by Brown Hal, dam sweepstakes, by Snow Heels, reduced the pacing mark to $1: 591 / 4$. This at Readvile, Mass., August isth.

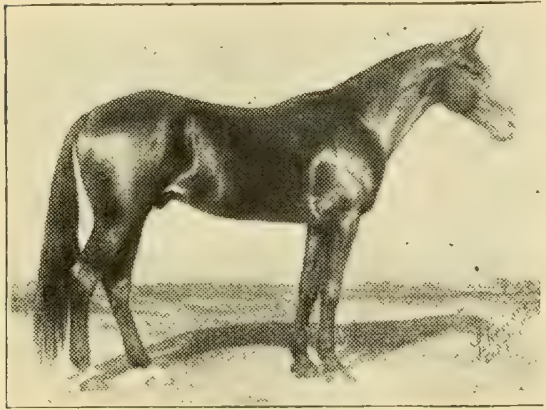

S'T IR IOINTICR, $1: 599^{1}$.

ts98, January 26 th.-The National Live stock Association organized in Denver, Colo. Oflicers: John W. Springer, of Denver, Colo. President; Hon, John M. Holt, of Miles City, Mont, Vice-President; George I. Foulding of Denver, Colo., Treasurer; a

189s. February 12th.-Judge Denny, the five-year-old son of Fresno, placed the tur record for two miles, running, at $3: 261 / 2$ This was done at Oakland, Calif, the horse having 10 ã rouncls up.

1898. March.-Organization of Continental Dorset Club with J. Fremont Hickman President: Joseph It. Wing. Secretary. Purnose, registration and advancement of Dorset sheep.

1898. April 1st.-Openzng of the modern and enlarged market for live stock at st. Josevir Jo. President, G. F Swift: Vice President and General Manager, J. T. Donnvan. Other Directors: Ernest Lindsey, $O$ M. Epencer, A. H. Veeder, Edward Morrj and I: G. Vaugh.

1898. April 30th.-The steamship Waeslani, of the International Navigation Com pany, left Philadelphia, carrying with other freighti an experimental shipment of

Imerican egas for sale in England. The wows were sold in Manchester. The average price was $1 \overline{\text { s }}$ cents per dozen.. Although the market was low at this time and the hipment was a financial failure, it was a pioneer movement, which led to good results. The shipment was made under the cirection of the Dairy Division of the Dureau of Animal Industry.

1998, July 16 th. - The rumning record for a mile and a half was made by Goodrich, a son oi Datton at Washington Park. rhicago, the time being $2: 301 / 3$

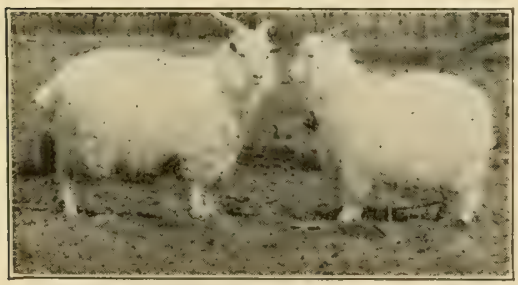

A jair of Texas Angoras

1398. August 30th.-The fastest authentic record made in the sale of range horses was estahlisher at the St. I,ouis National Stock Yards, where W. W. Callicott sold 1.200 hear in 91 minutes. They were sold in car-load lots: but even so, the performance tvas phenomenal. The horses sold belonged to the Crow Indian A gency, Montana.
1898, August :1st.-The two-mile record for a horse race over hurdles was taken by Friet, the then excellent daughter 'f heing $3: 45 \quad-5$. The race ivas run with $15 \mathrm{~s}$ pouncls up.

1×98.-Public attention was first called to he utility of crude petroleum oil in road hetterment through experiments made by the county of Los Angeles, in California, vhere six miles were oiled in that year ancler the direction of the supervisors.

1898 - This was the bisgest year in how recuipts at any market, chicago receiving S17, 11 heact.

1898.-1,owest wheat, in October, 62 cents whest of the year, \$1.85, caused by the eiter Corner, in May.

1898, Decomber.-Enumeration of cold ntorage of apples at this time indicated soo barrels in coinmercial warehouses, increasing by the year 1902 to $2,978,050$ barrels held in winter storage.

1898.- -J. W. Larmack's horse Jeddah de winner of the luglish Derby in the slow time of $y \cdot 47$ a honse named Batt was second.

1898.-Cotton crop of season 1898-99 arest up to this time, being $11,275,000$ mercial bales.

1899, May 20th. - In a trial against time at Dakland, Caif. the mare Lucretia Borgia, Y rimpres brutus, aralloped four miles in 7:11 "The next best time for the distance is $7: 16 \%$ made by The Bachelor, at Oakland. 1899.-Flying Fox, the great son of Orme, wred by the Duke of IVestminster, captured the lurlish Derly, making the distance in $3: 424-5$. Damocles man secona.

1899.-Mr. C. P. Bailey, of California, in:orter one mom rom Cape Town.

1899, October $3 \mathrm{~d}$. The three-fourths of a mile running record was broken by Firearm, a son of Raymond d'Or, over the straight course at Morris Park, the time being set at

1899, November 18 th.-Kyrat, a three-yearda by Teuton, ran two and one-half miles at Newnort, Ky., in $4: 241 / 2$.
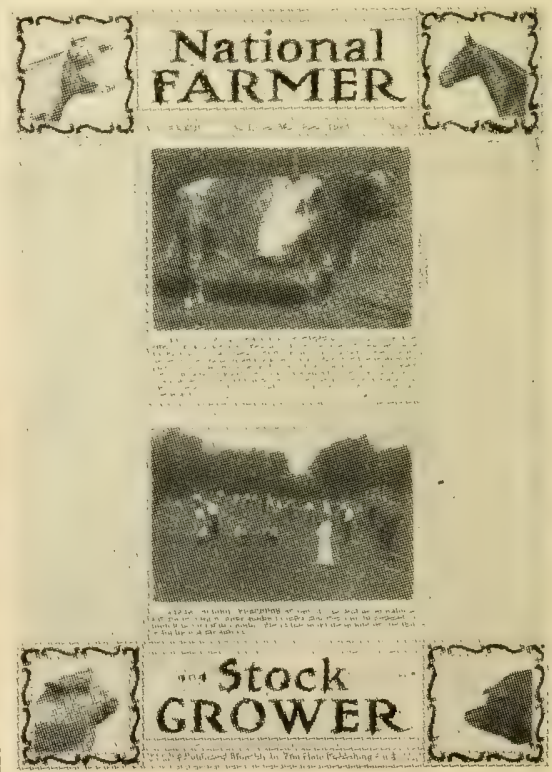

[899. -The National Farmer and Stock (Grower monthly furm vaper, established at the \&t. Jouis National Stock Yards by Philip I1. Hale, 
1899, Decenaber.-Home butter-fat tests of Guernsey cows: First prize, Lily Ella, 7,240 912.5 pounds butter: second prize, Lilyita, $7,241,828.95$ pounds butter; third prize, Countess Bishop, 7,869, 521. 71 pounds butter in one year.

1899-Tumois, "the five-year-old son of Florist, ran his record-breaking seven and one-half furlongs at Oakland Calif., in $1: 321 / 4$.

1899-Lowest whent, in December, 64 cents: highest of the year, in May, $79{ }^{1}$ cents.

1900.-In this year Col. 'T. C. Nye, who had a little home place in La Salle county, Texas, rear Cotulla, and a windmill which which he pumped to irrigate a small home warden, obtalned a few Bermuda onion seeds and planted them, and he raised the first crop of Iermuda onions in the United States. To George Copp, one of Col. Nye's neighbors, is due the credit of raising and shipping the first car of onions.

1900.-A valuable variety of long-staple mpland cotton, called Sunflower, is the off spring of seeds shipped to an oil mill a Yazoo City, Miss, in this year, and pur chased for planting by Marx Schaefer.

1900.--A bi-centenary exhibition of sweet peas held in Jondon in July.

1900. - The Prince of W'ales again won the Inglish Berby, this time. with Diamond Juhilee, a son of St. Simon. The time was 2:42, and Simon Dale was second.

1900.-Fourten incubator patents granted in this year.

1900.- Split-wing distributing shaft improvement in gear of cream separators, invented by John Joseph Berigan, of Orange, New Jersey.

1900. - The United States Census reported $5,700,657$ faruns in the United States, an in crease of $1,175,016$ in ten years.

1900.-Center of United States population. twenty miles east of Columbus, Ind.

1900.-Coney, black gelding, by McKinney. ram Grace Kaiser, by Kaiser, paced a mile to wagon in a race in $2: 05 \frac{1}{2}$, reducing the mark of 2:103/4 made in 1899 by Arlington.

1900,-Pride of the North, a standard variety of corn, originated about this time by

F. A. TVarner, of Sibley, Ill.

1900.-Center of the number of farms in the United States, 110 miles east by south of St. I,otis, in Wayne county, Illinois.

1900 - In a wacins record for teams, Charley B. and Bobby Hal broke all former records by guing a mile in $2: 13$. The best previous record was made in 1892 by Belle Button and Thomas Ryder. Charley B. was iy the same sire, dam by Royal George, Jr

1000, February 27 th.-At New Orleans, La, Julius Carsar, a five-year-old, ran a mile and seven-eighths in $3: 19$, the greatst record for the distance.

1900, June--Organization of the Illinois Seed Corn Rreeders' Astiociation.

1900. July 21st,-Oyimar, a six-year-old, carrying 109 pounds, covered the mile track at Washington Park, Chicago, in $1: 3 \mathrm{~s}$

1900. - The fastest mile trotting record to waon arainst time was made by The Abbot wa chimes, dim Nettie King, by hambrine King. It was $2: 05 \mathrm{~s} / \mathrm{s}$, and reduced the record of $2: 07$ formerly held by Lucille.

1900. A11 breeder of Shorthorns, sold fifty nine head at Chicago, Ill. for an average of $\$ 793.40$, the ton price being $\$ 2,600$.

1900. August 4th-At Brichton Beach $\mathrm{Y}$. Fithelhert estahlished a record 3:49 for two miles and a quarter. She caried 124 potends.

19)0.-After six years of uninterrupted supreniacy for dlix. The Abbot broke the troting record, establishing a mark of troting record. establishing a mark $1 / 4$ at Terre Haute, Ind. September $25 \mathrm{ch}$. $3: 031 / 4$ at Terre Haute, Ind., September $25 \mathrm{ch}$.
Ife was sired by Chimes, and his dam was Nettie King. by Mambrino King.

1900.-Paric IIorse Exposition. September 1st to 20th. Grand champion carriage hotse Sir Walter Gilbey's Hackney stallion, Hedon Syuire. Champion Percheron stallion, Dunham, Fletcher \& Coleman's Castelar, bred by M. Edward Perriott.
1900, Octoher 13th. -The famous mare Ethelbert negotiated a mile and threequartere at Morris park, $N$. Y in $2: 581 / 2$ This record is held jointly with Latson, who established the same time a year later; but the performance of Ethelhert is the more meritolious in that she caried 126 pound ainst latsons yo pounds.

1900, Novemier.-The Hapgood Plow Company, oi Alton, Ill., commenced the nanufacture of the (M. T.) Hancock Ad-

年,

1900, December 1st.-D'ermanent Intercolegiate Jive Stock Judging Contest instituted. the reward being a memorial called 'The Sponr Trophy, to be kept by winning teams from yeir to year, but not to hecome the property of any college. The trophy was offered by Mr. I. A. Spoor, Prestdent of the 'hicago Lnion Stock Yards, and is a great incentive to students in studies of stock udging

1900, - Iowet wheat in January, fi, 1 s. ents: highest, in June, $871 / 2$ cents.

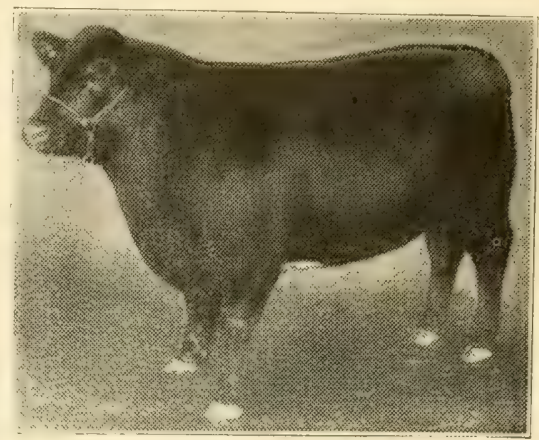

IDVANCE-Grand champion stteer.

1900, December.-Aberdeen-Angus steer Adrance, champion of International Exposl. tion, sold at $\$ 1.50$ per pound on foot.

1900, December.-Champion load of cattle at Chicago International Exposition sold at $\$ 15.50$ per 100 pounds, the highest car-load price on record.

1900, December 1st to 8th.-First Chicago International live Stoek Fxhibition. IV. F. Skinner, General Manager.

1900. December 4th-At Chicago, the famous Mevefort bull March on, 13th, sold at auction lyy Van Natta \& Son, of Fowler, Ill., bought by Moffat Bros, at $\$ 3,500$.

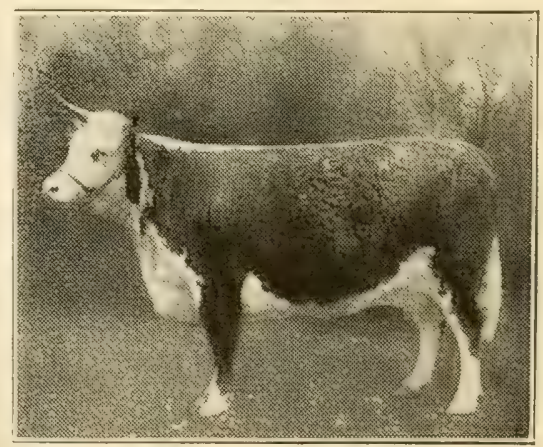

DOL.LY, 5th-Famous Hereford cow.

1900, Decamber 5th.-At Chicago, the Heteford cow, Dolly, 5 th 71,988 , and calf, bred hy John Hooker, of New London, Ohio, and owned by Clem Graves, of Bunker Hill, Ind.. sold to C. A. Jamison, of Peoria, Ill.. at auction, for $\$ 3,150$, being the record price for any Hereford cow to that date. 
1900.-At the Paris Univensal Exposition, Samuel Haugdahl, of New sweden, Minn,. U. S. A., won the grand prix d'honneur for held in May. This was the only instance held in May. This was the only instance during the entire Exposition in which the
highest honor was awarded to an individual exhibitor for a dairy product.

1900.-First American Royal Show at Kaisas City. Grand sweepstakes steer, Old Times, 94,03\%, pure-bred Hereford, exhibited hy T. F. P. Southam, of Chillicothe, Mo.

1900. - The heaviest total of horses and mules ever attracted to any one point up to this time were marketed at. St. Louis, the total for the year being 178,921 head.

1900, December 11 th and 12th.-K. D. Armour and James A. Funkhouser sold 10f Merefords at auetion at Kansas City for an average ot $\$ 351.60$.

1900.-Sir John Bennett Lawes, great agricultural experimenter, died at Rothamsted, England, at the age of 86 years.

\section{TIIE TWENTIETI CENTURY.}

1901, Tanuary 25th.-At Kansas City Clem Graves, of Bunker Hill, Ind., sold the threeyear-old Hereford heifer Carnation, 77,704, sire Acrobat, for $\$ 3,700$, to J. C. Adams, of Moweaqua, Ill. Average of 200

1901, January. - In an offelal test the Fiolstein-Friesian cow Lilith Pauline De Kol. 43,434 , owned by H. D. Roe, of Augusta, N. J., made 28,236 pounds of butter, 80 per cent. fat in seven days. She gave in this time 653.4 pounds of milk which averased 3.48 per cent, fat. This cow made the lar rest official record of any Iolstein-Friesian cow tested to date.

1901, February 12th.- Sale of Berkshire swine at Biltmore, N. C. Fifty-one head averaged $\$ 102$, the top price being $\$ 250$.

1901, March.-William Harris, of West Smithfield, Essex, Engrand, killed a twoand-one-half-year-old Jersey red boar. Live weight, 1,610 pounds; dressing 1,337 pounds; 21/2 feet across loin; $21 / 2$ feet across hams: feet in girth; 9 feet tip of nose to end of tail.

1901, March 6 th to $8 \mathrm{th}$.-Dispersion sale of Aberdeen-Angus cattle, herd of Charles Escher \& Son, of Botna, Iowa, at Chica:ro. 117 cows averaged $\$ 483.05$; twenty-six bulls averaged $\$ 465.95$; and 143 head averased \$479.95. Top sales: Female, Imp. Krivina, $28,475, \$ 1,700$; bull, Orin of Long Branch, $\$ 1,300$.

1901. March 12th and 13th. At South Omaha, Neb., T. R. Westrope \& Son sold eighty-one shorthorns for an average of \$45.85 per head. The sale included Sweet Violet, 2d, by Lavender King, and female calf, sold to G. M. Casey, of Clinton, Mo. for $\$ 3,705$, the record price for a Scotch Shorthorn female.

1901, April 5th. - Combination sale of Shorthorns at Chicago, IIl. Forty-six head averaged \$719.13. Victoria of Hill Farm, fith and female calf consigned by C B Dustin \& Son, of Summer Hill., Ill., sold to Frank Bellows, of Maryville, Mo., for $\$ 2,100$.

1901, April 12th. Jersey cow, Miss Thankful, 2d, 131,969; test seven days, April fith to 12 th, 24 pounds $41 / 2$ ounces butter; milk, 275 pounds. Owned by John A. Skannal, of Sligo, La

1901, April 18th and i9th.-Sale of Holstein cattle at Syracuse, N. Y., by Clarence F. \& Will C. Hunt. Average of 128 cattle big, llttle, old and young, $\$ 101.60$. The twenty-three official record cows averaged $\$ 179$.

1901, May.--Innp. Missie, 165, Shorthorn heifer, sold at $\$ 2,200$ at the auction of C. L. Cierlaugh, of Osborn, Ohio.

1901. May 15th.-At Greenville Ohio, Polled Durham sale of Stewart \& Martz in cluded the bull Cambridge Lad, sold at $\$ 1,000$, and the cow, Bracelet of Stillwater sold at $\$ 1,005$, both to $F$. Hines, of Indianapolis, Ind.

1901, May 22d-At Chicago, the Ilerefori cow, Dolly $2 d, 61,799$, John Hooker, breeder and owner, sold at auction with heifer calf for $\$ 5,1000$ to $\mathbf{N}$. Y. Bowen, of Delphi, Ind.
1901, May 23d, - Blue Girl, as a two-yearyear-old, took the record for a mile and a sixteenth in $1: 44^{3 / 4}$ at Morris Park, N. Y. 1901, May 30th. -At Coopersburg, Pa., T. S. Coover sold 108 head Jersey cattle at an average of $\$ 157.75$. The bull Golden Mon Mlaisir, 59,9:6, son of Golden Lad, sold to H. N. Higginbotham at $\$ 3,500$. The cosv, Goiden Rosebay, 157,333, sold to Biltmore arms for $\$ 2,775$

1901, June 4th.-At the combination sale George $\mathrm{F}$. Ward, of Hawarden, Iowa, sold the Shorthorn Duchess of Gloucester, with bull calf at side, for $\$ 2,500$ to Brown Randolph, of Indianola, Iowa, Average of sixty Shorthorns at this sale, $\$ 748.33$.

1901. Tune 12th. - Sale of Red Polled cattle tairfield, Neb, by S. Mickelvie \& Sons. The cow, Prairie Blossom, 12,803, sold to G. W. Coleman, of Webster City, Iowa, for $\$ 1,005$. Average for thirty-seven head, 257.03

1901. June-The mile running record over a circular track was broken by Brigadier at ISheepshead Bay, N. Y., the distance heing negotiated in $1: 37 \quad 4-5$

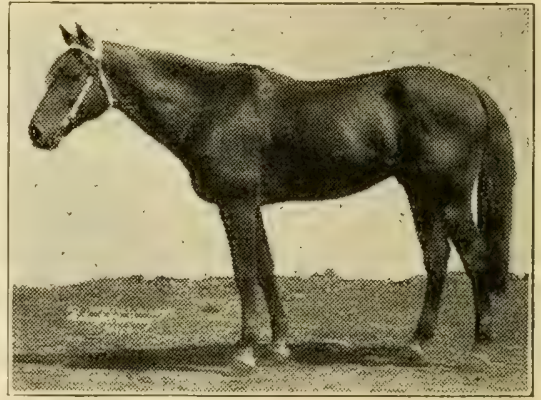

CPESCEILS, $2: 021 / 4$

1901.-On July 26th, Cresceus took the trotting record at $2: 02 \%$ at Cleveland, Ohis, and on August $22 \mathrm{~d}$ further reduced this mark to $3: 021 / 4$. This was at Columbus, Ohio. The first quarter was in $293 \%$; the half, $593 \%$; three-quarters in $1: 301 / 4$. This was at the time the world's trotting record; at this time-in 1906 -it is the stallion record. Cresceus is a chestnut horse by the great Robert McGregor, dam by Mambrino Howard, and in all his record-breaking performance was driven by his owner, Geo. 11 . Ketcham

1901, August 7 th.-At Chicago, Geo. Harding \& Sons, of Waukesha, Wis., sold fortythree shorthorns at an average of $\$ 656.85$.

1901, August 15th.-Cresceus defeats The Abbot in a famous trotting contest at Brighton Beach. making world's mile trotting record in a ace.

1901. August 22d.-At Columbus, Ohio. Cresceus lowered the trotting record to

1901.- In this year Hon. F. D. Coburn, Secretary of the State Board of Agriculture of Kansas, issued a book entitled "Alfalfa," containing directions for planting, growing and harvesting this excellent forage crop. resulting in immense increase in alfalfa acreage in the Inited States.

1901, September 5 th. - The best record eve: made for a mile and seventy yards was established by Jiminez, a three-year-old, carrying 101 pounds. It was $1: 42 \frac{1}{2}$, and was made at the Harlem track, Chicago.

1901. October 2d.-McChesney, in his twoyear-old form, established the six and onehalf furlong running record of $1: 18$ 4-5 at Harlem Park, Chicago.

1901, October $3 \mathrm{~d}$ - At Newton, Iorva, E. S. Donahey sold fifty-four Shorthorn cattle for an average of 13646,35 , including the cow Early Bud, id, at $\$ 1,500$, and nine other females upward of $\$ 1,000$. 
1901.-The English Derby was won by an American. Wm. C. Whitney, with the sensaional horse, Volodyovski, a son of Florizel, II. All records for time were broken, the distance being covered in $2: 40$ 4-5.

1901, October 25th.-At Memphis, Tenn. Little Boy, by Kenton, dam Jenny, by Longfellow, broke the mile pacing recoril to wagon, against time, putting the mark at 2:011/2. The former record, $2: 03 \frac{1}{4}$, was made by Bumps in 1889.

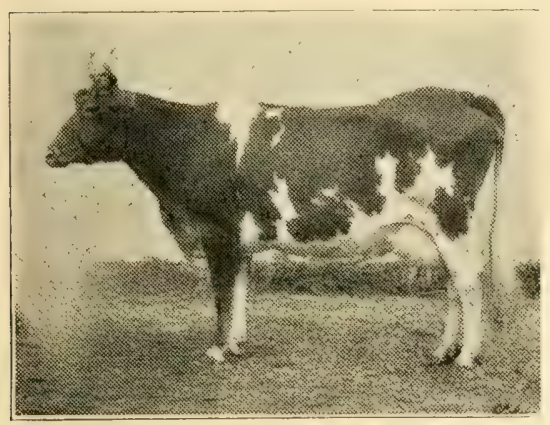

GUERSEY COWV - MARY MARSHALL. This distinguished cow was the winning cow in the Pan-American model dairy herd, 1901. The six-months record was 5,611 pounds of milk; 5.36 per cent. butter-fat; 354.26 pounds of churned butter. The profit in butter pro duction was $\$ 59,43$, the next highest being $\$ 51.58$.

1901, November 3d.-Mary Marshall, 5,604, winning cow in butter production in l'anAmerican model dairy herd. Record for sis months, 5,611 pounds milk, 5.36 per cent. months, 5,611, pounds mik, 5.36 per cent. to 354.26 pounds churned butter. Profit in production of butter-fat, $\$ 59.43$ in six months.

1901, November 3d.-A wards in the Breed Test in Pan-American model dairy. Prize for net profit in butter-fat won by Guernseys by a net profit of $\$ 4.66$. The prize for net profit in churned butter won by Guernseys by net profit of $\$ 5.86$. The prize for net profit in total solids won by Holsteins hy a net profit ot $\$ 26.44$. The profit in total solids and gain in live weight won by Hol steins by net profit of $\$ 31.53$.

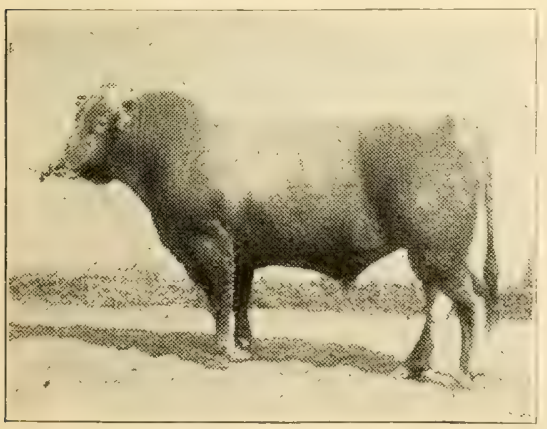

BROWN SWISS BULI-DUKE OF RIVER MEADOW. Highly representative bull of this fiue breed of dairy cattle and first-prize winner at the Pan-American Show of 1901. The Brown Swiss cattle are very handsome in appearance, not unlike the Jerseys, but distinctly larger and with more claims to beef qualities.

1901.--Short corn crop in the United States; yield, 16.7 bushels per acre. Total, $1.552,520,000$ bushels; smallest crop since is 894 .
1901, November 7th.-At Chicago, Ill., W. o. Elatt, of liamilton, Canada, sold fortyilse shorthorn eattle for an average of $\$ 1,123.22$. Imported Cicely, the Queen of England heifer. sold to J. G. Robbinis \& Son, of Iforace, Jnd., for $\$ 5,000$. The bull, Jord Banfi, sold tn Ge.. E. Ward, of Hawarden. lowa, for $\$ 5.100$.

1901. Nowenuber 14th and 15th-Breeders' sale of IIolstein eattle at syracuse, N. Y. Average for the eighty-five head, \$121.:5 W. C. Hunt, of Liverpool, N. Y., manager.

1901, November 20th and 21st-First IIereford rattle sule at East St. I.ouls by I. F. B. Sotham, of Chillicothe, Mo.

1941. Uecomber 2d.-The IJolstein cov. Mercerles Julios Pietertje, completes gevenlaty record of gy pounds 5,7 ounces of butter at South Side Farm, Whice Bear Lake,Minn.

$150 \%$, Decemher.-Home butter-fat tests of Guernsey cows: First prize, Glenwood Girl tith, 9, 113, 6.7.5 pounds butter" second prize, Primrose Tricksey, 7,236, 592,6 pounds butter; third prize, Gipsy of Racine, 9,639. 609.9 pounds butter in one year.

1001, December 6th.-Galloway cattle 3old it Chicago, 111.; thirty-three head average $\$ 2 S$. Sale included Imp. McDougall, 4 th, of 'Tarbrench, champion Scottish bull, solit to O. N. Moody, of Atlanta, Mo., for $\$ 2,000$.

1901, December 9th.-Grand champion at International Live Stock Show. The Woods Erincipal, Hereford steer, 1,645 pounds at twenty-five months. eFd by John Lethan or Ger. P. IJenry, of Goodenow, Ill.

1901.-Great whent crop in the Inited States, $748,460,000$ bushels; harvested while the corn crop was drying up.

1901.- Lowest whent, in July, $631 / 8$ cents: highest of the year, in December, $791 / 2$ cents.

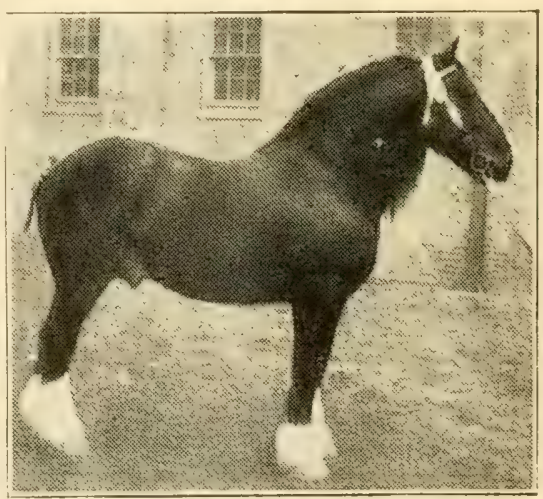

BLAISDON PLUTO-Shire stallion. Orvned and exhibited by 'Trumans" Pioneer Stud Farm, Bushnell, Ill. Champion Shire stallion, any age, at the Chicago International Exposition, 1901 .

$190 \%$, January $7 \mathrm{th}$.- Record price for Hertford bills broken by sale of bull "Perfection" for $\$ 9,000$ by Thomas Clark, of Beecher, Ill., to G. H. Hoxie, of Thornton, Ill.

190\%, January $9 \mathrm{th}$ - $\mathrm{A}$. P. Nave, of Attica, Ind. sold Percherons at auetion. The top price was $\$ 1,630$, paid by $A$. B. Puterbaugh, of Milledgeville, Jll., for the stallion Abo, $2,6 \$ 6$. The average was $\$ 469.25$. for fortyone head.

190\%, January 28 th to 30 th.-A sale of IIerefords under management of $T$. F. $\mathrm{B}$. Sotham, held at Kansas City, resulted in an average of $\$ 373$ for 113 females and $\$ 292$ for seventy-one bulls. The top price, $\$ 3,995$, was pail by the Wabash Stock Farm Company for the Improver bull Good Cross, 120,180 . The average of 134 head was $\$ 341.70$.

190:- - In Mrs. Alice Morse Farle's volume on Colonial Gardens, published this year. she says that the largest apple tree in New Fngiand is at Cheshire, Conn., its trunk measuring, one foot above all root enlargements, thirteen feet eight inches in circum- 
ference. Its age is traced hack 150 years. She also says that at the old Rhode Island home of Bishop Perkeley, who died in 175,3 , the apple trees of his day are yet standing. 1902, January 30 th and 31st.-Sale of Poland-China swine by Winn \& Mastin, of Mastin, Kas. 105 head sold for an average of $\$ 124,27$.

1802 , February 4 th and 5th.-During Aberdeen-Angus cattle sale at Chicago, I11. the average for twenty years was broken, eighty-two head selling for an average of Sfit 1.45. This included hulls and females.

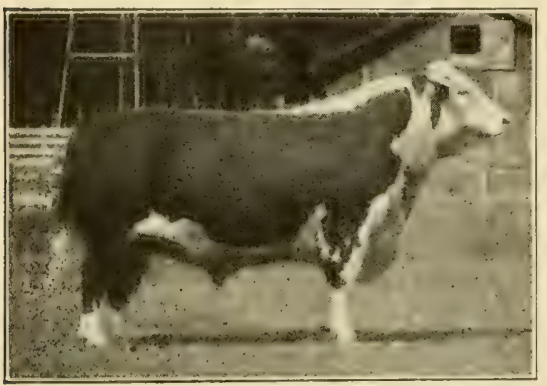

ONWARD, 4th-Famous Hereford bull.

190\%, February 5th.- "Blackcap Judy," the famnus Aberdeen-Angus yearling heifer, was sold for the record price of $\$ 6,500$. C. H, ovner, and M. A. Judy \& Son, of Willianisport, Jnd., her purchasers.

190\%, February 5th.-New high mork in prices of Aberdeen-Angus bulis established. "Prince Ito," sold by M. A. Judy \& Son, of Williamsport, Ind., to B. R. Pierce, of Creston, 111 , for $\$ 9,100$.

1902, February 15th. - Sale of Percheron borses by 3. W. \& J, C. Robinson, of Wichi1a. Kas. Twenty-three head made an average of $\$ 4 G .70$

1902, February 25 th to 27 th.-Combination sale of Hereforl cattle at Kansas City. Top price of sale, Mrs. Cross' bull, Royalty's Java, sold for $\$ 650$. The bull averize, thirty-nine head, was $\$ 208.45$. The female average was $\$ 318.15$ for ninety-six head. Average for 135 head, $\$ 286.45$.

190\% - Boston Work Horse Parade Associ ation held in this year, and the pioneer in holding work horse parades in this country.

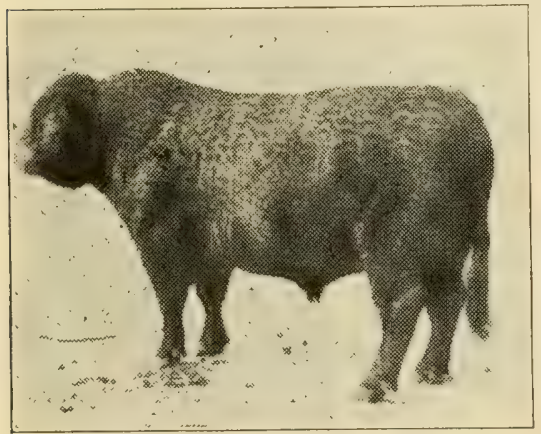

FAT RYAN OF RED CLOUD-Champion Galloway bull at the Chicago International Show, 1906.

1902, February 28th and March 1st.-1Dis. persion sale of Hugh Paul Galloway cattle at South Omaha. The twenty-four bulls averaged $\$ 20 \$ 10$ and eighty-nine females $\$ 17 \$ .60$. The 113 hear made a general average of $\$ 184.85$
1902.-Ard. Patrick, a son of St. Florian, owned by John Gubins, won the Euslish Merby, Rising Glass being second. The time $2: 121 / 2$

190\%, March 6th and 7th.-Imp. Spicy Clara, shorthorn yearling heifer, International prize winner, sold to Geo. Harding s Son, of Waukesha, Wis, for $\$ 1,500$. At a Chicago sale of shorthorns the general average was \$499.80 for eighty-nine head.

190\%, March sth.-At Chicago, Red Polled cattle sale by $A$, F. \& J. F. Dobler, of Girard, Pa, Tol price, $\$ 600$, for the couv Mayflower, 2d. Average for fifty-seven head, $\$ 189.20$

190:- March 18th-Dispersion sale of Shorthorn eattle at Kansas City by Col. W. 12. Nelson-fifty-six head-average, \$3410.35 Top price for Imp. Lavender Lilly, sold to D. R. Hanna for $\$ 1,600$, next price beins $\$ 1,590$ for Irrp. Miranda and cow calf by mer ther.

190\%, March 15th and 19th.-Combination Abordeen-Angus cattle sale at Omaha by Chas, Escher, Jr. Average for 111 hear. \$13. Top price, $\$ 1,110$ for Isabella, 4 th, of Millsland, 21.891, and female calf, pair by E. Reynolds 3 Son, of Prophetstown. Ill., to E. T?. Davis, of Iowa City, Iowa.

190:, March 24th.-Sale of forty-one shortliorus by $F$, R. Stangland of Marathon, Jowa. Averace, $\$ 485$ per head. Top price, $\$ 1,775$, for goth Linwood Victoria and cow call, paid by C. C. Bigler \& Son, of Hartick, Iowa.

190\%. March 25.5h. Shorthorn rattle sale by $H$. F, trown, of Minneapolis, Minn. Average of thirty-five head, \$750. Top sales: Imp. Juno and bull calf, $\$ 1,550$, paid by W. H. Dinwoody, of Minneapolis, Minn. bull Royal Eanner, 150,993, bought by W. O Carpenter, of Puliwana, S. D., at $\$ 1,505$.

$190 \%$, March 25 th and 26th.-Hereforl cattle sold by T, F, B. Sotham and others. Average for 148 head, \$323.25. Top price, 1,650 , for Corrector cow Galatea, 107,723. bought by G. E. Ricker, of Ashland, Neb.

1902, March 27th.-Hector Cowan, Jr., of Paulliana, Iowa, sold forty-nine Shorthorns, averaging \$512.05. Top price pald by Join Fasmus, of lahe City, Iowa, for the cow Dalmeny Princess, 9th

1902.-Cattle in Ireland, 4,782,221 head, largest number known in that country.

190\%, April 1st.-Farmers' and Stockmen's Business Directory issued by Philip $\mathrm{H}$. Hale, St. Louis, Mo.

1902, April 3d-Geo, M. TVoody sold fiftyfour shorthorn cattle for an average \$39!.10. Top price, $\$ 1,750$, paid by $F$. A Schaffer \& West Bros., of Estherville, Ia. for Imp. Lily of the Valley, 17th.

190\%, April 14th.-Shorthorn sale at Chicago by George Bothwell, of Nettleton. Mo., and fifty-four head averaged $\$ 479.50$ Notable sales included the bull Nonparei. of Clover Blossom, 153,672, at $\$ 1,710$, paid son, and the bull Nonpareil Hero, 170,793 , at $\$ 1.710$ bought by i1. Hagenfeldt of Storm Lake, Ia.

190:, April 17th,-Sale of Shorthorns by G. W. Brown \& Randolph Bros, of Indiancla, Ia, The average for forty-nine head was \$5S4.30 Notable sales included Victoria of Village Park, $3 \mathrm{~d}$, and bull calf bought by N. A. Lind, of Rolfe, Ia. fur $\$ 3,500$, and Imp. Gazelle, sired by Royal Star, for \$2,105, paid by Bigler \& Son, of Hartwick, Ia

1902, April 29th and 30th.-At Syracuse N. Y..'W. C. Hunt's second semi-annual sale of Ifolstein cattle. Average of ninety-nine head, $\$ 103$.

1902. May 1st and 2d.-At Sioux City, Ia. initial combination sale of Herefords. The 113 head averaged $\$ 229.40$.

1902 May $3 \mathrm{~d}$-.. At Sioux City, Ia, combination sale of Shorthorns. Average $\$ 366.50$ per head. Notable sales included Imy. Dalmeny. Regina, 5th, sold by $\mathrm{C}$. C Bigler \& Son to Henry Weiss, of Westphalia Kas, for $\$ 1,375$, and May Queen, with cow calf, hought by John Rasmus, of Lake City, Ia, for $\$ 1,825$.

1902.-Great corn crop of the United States; officially, $2,523,648,312$ bushels, from $93,043,613$ acres. 
190\%, May 13 th and 14th.-Combination sale at Indianapolis, Ind. Herefords, sixtytwo head, sold for an average of $\$ 392.35$. including Miss Java, 2d, 94,200, and calf, consigned by Mr. Daugherty Wabash, Ind.. and sold to Ed. Hawkins, of Larl Park, for $\$ 3,500$. Shorthorns, sixty-
four head, averaged $\$ 42 \%$ including 55 th Duchess of riloster, consigned by E. E. Sovers, of Warren, Ind., and bought by Geo. Harding \& Son, of Waukesha, Wis., for $\$ 2,105$.

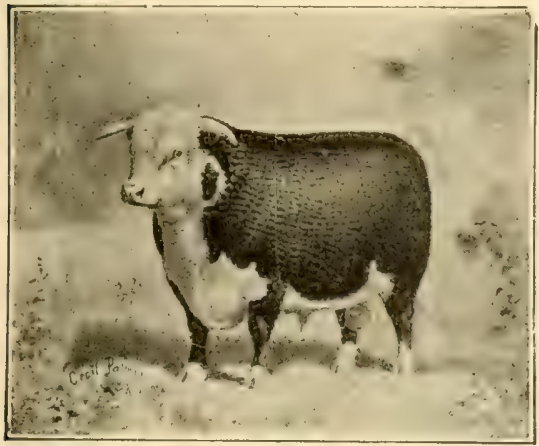

FENTHY LARS-I famous Hereford bull Prize winner at many shows. Stock bull a Grandview Heretords. Owned

Comstock \& Son, Albany, Mo.

1902, May 17 th to $21 \mathrm{st}$-Ohio Shorthorn Sales: H. G. Walker, of New Madison, thirty head; average, $\$ 107.70$; E. S. Kelly, of Yellow springs, thirty-six head, average $\$ 590.40$; top price, $\$ 1,625$, paid by $I V$. L. Wood, of TVilliamsport, O., for Imp. Missie, $15 \mathrm{sth}$; C. I. Gerlaugh, of Osborn, O., thirty three head; average, $\$ 610$; top price, the bull Master of the Ring, 171,376, sold to J. T. Rvan \& Son, of Irwin, Ia., for $\$ 1,705$ IV. I. Wood, of WVillamsport, O. forty-four head: average, \$350: top price, female Imb. Proud Fancy, sold at $\$ 2,050$ to $\mathrm{W}$. T. Miller \& Sons, of Winchester, Ind.; top-priced bull. Choice of the Ring, sold to Brown \& Ran dolph T3ros., of Indianola, Ia, for $\$ 1,550$,

1902, May ?2d and $23 \mathrm{~d}$-Cambination sale of IIereforls $t: y$ C. A. Jamison, of Quincy I11. and others at Chicago. Eighty-three hear averaged $\$ 323$. Top price was $\$ 2,109$, bid for Iady IViltona, a daughter of Dale, by Ed. Hawkins, of Earl Park, Ind,

1902, May 2Sth. - Shorthorn cattle sale a Morning Sun, Ia, R. G. Robb \& Son's average $\$ 3 \$ 6.40$ for twenty-eight head; A. Alexander's average for twenty-five head \$526. including the cow Mary of Bluff View, sold to Korns \& Lee, of Hartwick, Ia, for $\$ 1,2: 10$.

190\% May 30th and 31 st - Linden Grove, sale of imported Jerseys hy T. S. Cooper, of coopersburg, Pa. The $16 \mathrm{~s}$ head averager $\$ 340.60$. The sale included the champion liull Flying Fox, sold to T, W. Lawson, of Boston, Mass. for $\$ 7,500$. The highest price for a female was $\$ 3,100$, for the cow Lady Fontaine's Rosette, 162,120 , for $\$ 3,100$.

1902, June. Straight Texas steers sold on the Chicaso market at $\$ 7.65$ per 100 pounds, the record price Shipped by Ed, Farmex, of Fort Worth, Tex.

1902, June $3 d,-N$. A. Lind, of Rolfe, Ia., sold fifty-five Shorthorns for an average of $\$ 766.30$. Top price. $\$ 3,800$, paid for the cow Red Crest sire Imp. Scottish Chief, sold to C. C. Bigler \& Son, of Hartwick, Ia.

1902, June 5th and 6th.-Shorthorn cattle sale by C. C. (Bigler \& Son, of Hartwick, 1a. The 115 head sold for $\$ 94,715$, an averla. of the sale included Toe of $\$ 23.60$ per head, 000 to $\$ 2,500$, not thirty-one head at $\$ 1,000$ to $\$ 2,500$, not
including the cow Wild Fyes, 61 st, sired by Airdrie Duke of Hazelhurst, bought for $\$ 3,040$ by G. IV. Brown \& Randolph Bros., of Indiunola, Ia., for $\$ 3,040$.

1902, June 10 th and 11 th. At Chicago, combiration Ingus cattle sale. 101 head averaged $\$ 312.10$. Top prices: $\$ 2,000$ paid by Silas Igo, of Palmyra, Ia., for the cow Belle
Bloomer, 2el, 23,218, and Edgewood Belle, 2,260 , lioth consigned by Cantine Bros, \& evenson, of liolstein, la.

190\%. June 18th,-Indianapolis combination sale ot Polled Durham cattle. Averase of fifty-two head, $\$ 424.70$. Top price, coiv colden Heather, sold to J, If Jennings, of 190:3. July ith-Major Daingerfield broke the record for a mile and five-eightho over Sheepshead Bay, N. Y. in 194:, July 5th.-At Brighton Beach, N.Y. fold Hees established a new Derby record gothest over a circular track. 190\%, fuly ";0th.- Isonnibert captured the mile and one-eighth running record by going the distance in 1:51 at Birighton Beach, N. Y. The record of $1: 5 \mathrm{~L} \quad 1-5$ was formerly Watercure.

1902, July 39 th. Sale of Shorthorns by $\mathrm{A}$. Chrystal at Marshall, Mich. Top price. $\$ 1,500$, for Inmp. Lady Bell, $3 \mathrm{~d}$, and female calf, bought by E. G. Stevenson, of Detroit, Iich. A verage for sixly-seven head, $\$ 266.95$.

190:, August. - Native beef cattle sold at Chicago up to $\$ 9.00$ per 100 pounds.

1902, August $3 \mathrm{a}$ - Pueblo (Colo.) Stock Iards onened for business. The oflicers are as follows. C. G. Warner, President, of St. St. Louis, Mo.: N. Douthitt, Vice-President ind General Manager, of Kansas City, Mo; Burnett, Superintendent, of Pueblo, Colo.

190:, August 5 th.-Iraly Union Stock Jards at Atlanta, Ga., organized. President. I. B. Brady; Vice-President, John Oliver; Secretary, J. M. Brady. Opened for husiness ether 10th, 1900.

$190 \%$ August 13 th.-Shorthorn sale at Hamilion Stock Yards, Canada. The fiftyeight head averaged \$425.43. Top sale, the Imp. Wanderer's Last, consigned by Captain T. Robson of Ilderton Ontario, and sold to Geo. Bothwell, of Nettleton, Mo., for

1903. August 16 th-Lord Derby bay relding, by Mambrino King, dam Claribel, y Almant, Ir. established the mile trotting record to wagon in a race of $2: 05 \%$, beating the the previous record of $2: 10$, held jointly by John A. McIierron and The Monk.

190: August 18th. -The Musketeer negotiated seven-eighths of a mile at the Saratoga, N. Y.. track in 1:25. This was the best running record over a circular track.

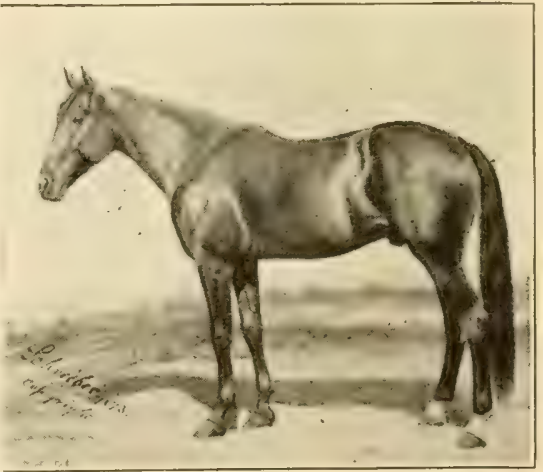

ELECTIONEER - FAMOUS TROTTING SIRE By Hambletonian. Sire of Arion. $2: 073 \%$ : Sunol, 2:081/4: Palo Alto, 2:08\%; and many others with fast records. From pho. tograph picture taken in 1873 by Schreiber \& Sons. Philadelphia. Pa.

190\% August 21st. - At a sale of PolandChina swine by Shallenburger \& Cox, of Ohio. Mr. L. Tukens, of Disco, IIl., bought the five-year-old boar, Big Chief Tecumseh, d. for $\$ 2,100$.

1902, August 24th-Lou Dillon trots the first mile in $2: 00$ at lieadrille, Mass. 
1902, August $27 \mathrm{th}$ and $28 \mathrm{th}$.-Hereford cattle sale at Des Moines, Ia. The seventy. two head averaged \$218. Top price of the sale, $\$ 540$.

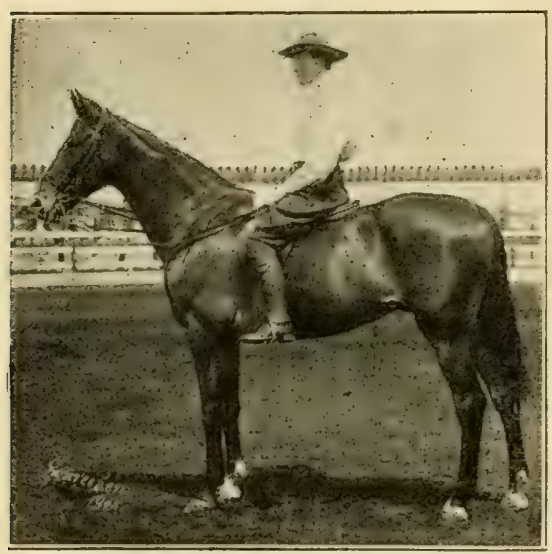

HEATHERBLOOM-The Ereatest jumper of them all, with Donelly up. Copyright photo by Schreiber in 1902 .

$190 \%$, September $1 \mathrm{st}$. - The fastest running time for a mile and three-sixteenths was mark being $1: 57$ 2-5.

1902. September $2 d$ and $3 d$. - Sale of Hereford cattle at IJamline, Minn. The sixty-one head sold for an average of $\$ 225$.

1902, September 4th.- Sale of Shorthorns at Hamline, Minn. Forty-eight head averaged $\$ 450.50$. Top price, $\$ 1,500$, for $N$. A. Lind's bull Fearless Victor, 174,014, bought by John Lister, of Conrad, Ia.

190\%, September 4 th:-First public sale of Berkshires at the Ohio State Fair. Average of forty-four head, $\$ 2 \$ .75$; top price for boar, $\$ 70$; for sow, $\$ 100$.

1902, September 9 th. Shorthorn sale by Mrs. Virginia C. Meredith and J G. Rohbins \& Sons at Cambridge City, Ind. A verage of thirty head, $\$ 419.65$. Top price, $\$ 1,200$, for Imp. cow Maggie, 12 th, sold to E. E. Souers. of Warren. Ind.

1902, September 16th.-Extraordinary sale at Indianapolis, Ind., of Herefords owned by Clem Graves, of Bunker Hill, Ind. The forty-three head averaged $\$ 1,007$. Top prices include the bull Crusader, $\$ 6.596$, by Ed. Hawkins for $\$ 12,000$. The cow Dolly, $2 \mathrm{~d}, 61,799$, also bought by Ed. Hawkins for $\$ 7,000$.

1902.--On September $29 \mathrm{th}$, the sheep receipts at the Chicago Union Stock Yard were 59,362 head, breaking all previous records for a single day's run at any records

1902, October $7 \mathrm{th}$ and 8 th - At Chillicothe, Mo. F B Sotham ina. At of high-class stock cattle auction sales by selling 2,000 head of young cattle frrom the Panhandle of Texas.

1902, October 9th-Shorthorn sale

Charles E. Ladd, of North Yamhill, Ore a Spokane, Wash. Average for thirty-nine head, \$330.25. Top price, \$1,000.

1902, October $14 \mathrm{th}$ to $16 \mathrm{th}$. Shorthorn combination sale at Victor, Ia. Average for 105 head, \$379.20. Top price, $\$ 1,140$, for cow Victoria of Hill Farm, sth, consigned by C. C. Bigler \& Sons, and sold to E. S. Kelley, of Fellow Springs, $O$.

1902, Octoher 15th.-Sale of Polled Dur hams at Indianapolis, Ind, Average for forty head, \$128.90.

1902.-During the week ending October 18 th, 162,459 head of sheep arrived at the Chicago Union Stock Yards, the largest on record for a similar period.

1902, Detober,-Western grass range cattle sold at $\$ 7.40$ per 100 pounds; record price.
190', Octoher 16th and $17 \mathrm{th}$-Combination ale of Tereford cattle at Indianapolis, Ind. Averagc for 104 head, $\$ 407.05$. Top price, $\$ 1,500$, paid by S. H. Godman, of Wabash, Ind.. for the cow Beryl, 103,641, consigned by F. 1. Nave, of Attica. Ind.

1902, October 20 th to $25 \mathrm{th}$.-Berkshire swine at auction at Kansas City. Average of sows, $\$ 58.60$; average of boars, $\$ 48.60$; average of eighty-seven head, $\$ 53.70$.

1902 October 21st. At Memphis, Tenn. Cresceus placed the two-mile trotting record at $4: 17$ in his trial against Onward Silver's mark of $4: 283$.

1902. Octoher 21 st and $22 \mathrm{~d}$-Combination sale of Herefords at Kansas City., Mo, The average of ninety-six head was $\$ 304.40$. Top price. $\$ 1,005$, for Columbus, $29 \mathrm{th}$, consigned by Benton Gabbert, of Dearborn, Mo., and bought by $H$. Mclildowney, of Chicago Heights, Ill.

1902, October 21st and 22d.-AberdeenIngus rattle sale at Kansas City, Mo. Average of ninety-eight head, $\$ 176.10$.

190\%.-All leading live stock markets broke the one-day cattle receipt record. Chicago's total on December 1st was 36,553 head. The big day at Kansas City was Sentemlier 16th, when 29,216 head werc recrivec Septemtier $29 t h$, when 13,228 head arrived; while the sit. Louis record was 12,193 head, made September $23 \mathrm{~d}$.

190\%. October $23 \mathrm{~d}$-Sale of Gallowgy cattle at Kansas City, Mo, Average for forty-seven head, $\$ 153.60$. Top price, $\$ 1,115$, paid by $O$. H. Swigart, of Champaign, Ill." for the cow Dorothea, 18,673, consigned by Y. Moody, of Atlanta, Mo.

190?. October $23 \mathrm{~d}$ and $24 \mathrm{th}$.-SJorthorn cattle sale at Kansas City, Mo. Average of sixty-six head, \$247.50.

1902, October 2sth,-At Memphis, Tenn., Direct Hal and Prince Direct, both sons of Direct, 24,113, paced a mile as a team against time and set a new mark of $2: 05 \frac{1}{2}$. The record prior to this was $2: 08$, made by John $\mathrm{R}$. Gentry and Rohert $\mathrm{J}$, in 1897.

1902, October $28 \mathrm{th}$ and $29 \mathrm{th}$.-Red Polled cattle sold at Chicago by Captain V. T. Hills, of Delaware, 0 . Average for ninetytwo head, \$2\$3.30. Top-price female, Popsey, $3 d$ sold for $\$ 1,125$ to C. S. Carr, of Elm Grove, W. Va. Top-price bull, Popular, 856 , sold to J. H. Smith, of Chillicothe, O., for $\$ 1.200$.

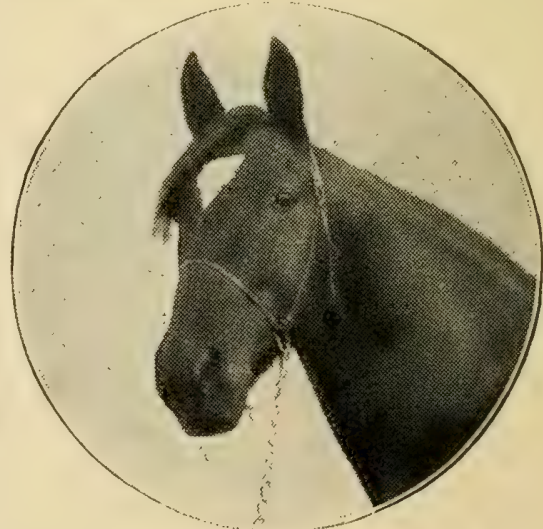

THE INTELLIGEN'T HEAD OF MOKOFamous trotting stallion, sire of futurity winners.

1902, October 21 st to 25 th. $\rightarrow$ Sale of Poland-China swine at Kansas City, Mo. The boar average was $\$ 58.70$; sows, $\$ 61.50$; average of 161 head, $\$ 60.50$.

1902, September 20th. - Sale of Percheron horses by $H$. G. MeMillan, of Rock Rapids, Ia Mare average, \$267,40; stallion average. $\$ 630.70$ average of forty-two head, $\$ 452$. Top price for a stallion, $\$ 1,175$. 
1902, October $31 \mathrm{st}$. - The stallion Cresceus iroto two milos in $4: 17$, establishing a worla's record.

190:- Iowest wheat, in August, cents; highest, in September, 95 cents.

190\%, October 31st. - At Los Angeles, Calif., Zambra. bay felding by Mckinney, dam by fairmount, broke the tive-mile troting record in a race against four other horses. formerly was 12:30\%, the record of Bishop Hero.

190:, November,-Fort Warth Stock Yards fornially opened for business with support of modern packing houses, president, secretary, O. W. Matthews; General Manager, W. F, King.

190:, November 5 th and 6 th, - NberdeenAngus combination sale. Average of seventyuine head, $\$ 387.40$. Top price, $\$ 1,050$, for Imp. cow Pride of Aberdeen, 167th.

1902. - As a test of endurance, in the summer of 1902 Colonel Baskakov, of the Russian Headquarter Staff, undertook to ride from St. Petersburg to Odessa, a distance of 1,716 versts $(1,128$ miles $)$. Using two horses an English bred one and an Arab, alternately, he performed the journey in twelve
lays, an average of ninety-four miles per diems, an average of ninety-four miles per condition, though neither had been subjected to any preparatory training-for the under taking.

190\%. November 12th.-Sale of Shorthorn cattle by J. WV. Smith \& Son at Allerton, Ia. Top price paid by Randolph Bros. \& Igo, of Indianola, Ia, for the cow Missie May, 2 a per heal.

190:- Twenty-six auctions of pure-brea cattle held at Chicago, Ill.,embodying the six leading beef breeds and embracing 1,7 9 head, sold for a total of $\$ 611.817$, or an average of $\$ 342$ each.

190\%. December $S$ th and 9 th.-Combined sale of Herefords at Kansas City; Mo. Aver age for seventy-six head, $\$ 227.05$. Top price, consigned by Benton Gabbert, of Dearborn Mo., and bought by G. E. Reynolds, of Kansas City, ML.

1902, December 1sth.-Hereford sale at Wabash, Ind. Average for sixty-three head, 3225.70. Top price, $\$ 1,300$, for the cow Clotho, 18th, 117,714, consigned by Wabash Stock Farm Company, and sold to Ed. Haw kins, of Earl Park, Ind.

1902. December 19th-Sale of Percheron lorses at Kansas City, Mo, by D. R. Hanna. Mares, twenty-one head, averaged \$313.80; nine stallions averaged $\$ 570$; average of sale. \$342.

1902.-Calf receipts at Chicago, Ill., were phenomonal the total for the year, viz. i51,747 head, ostablishing a new record.

$1902 .-T h e$ year's sheep record of all markets was hroken at Chicago, Ill. During the year the total aggregated 4,515,716 heag.

190:, December 13 th.-Targest recelpts of cars in one week at the Union Stock Yards, Chicago, 8,474.

1902, December.-Chicago International Live stock Fxposition. Grand champion beef animal, the Polled Angus steer, Shamrock; weight, 1,805 pounds as a two-yearold. Fed by the Iowa Agricultural College.

1903, January 1st.-United States Department of Agriculture estimate of number of farm animals: $17,105,227$ milch cows, 44, 659,206 other cattle, 46,922,624 hogs, 63,964, 396 sheep, 16,557,373 horses, 2,728,0ss mules.

1903.-Promising new fruits illustrated and described in Year Book, Department of Agriculture: Akin apple, Terry apple, Heley peach, Welch peach, Splendor prune, Sugar prune, Headlight grape, Cardinal strawberry.

1903, April 1Sth-Holstein-Friesian champion cow Sadie Vale Concordia, A. R. O. 1,121, produced under official test 694.3 pounds of milk in seven days, containing 30 pounds 10.16 ounces of butter; also produced in thirty days 2,754.6 pounds of milk, containing 123 pounds 10 ounces of butter. Dwned at time of test by Messrs. Meddam E Von Heyne, of Brothertown Stock Farms. Dean Heyne, of Brothertown Stoch
Deansboro, Oneida county, N. $\mathbf{T}$.
1903, June 9 th.-New York spot cotton, 2.40 cents per pound; highest in fifteen

190:3, June $11 \mathrm{th},-\Lambda t$ Chicago Shorthorn \$ale, averase $\$ 371.25$ for forty-elght head. $1 \mathrm{mp}$. I.ord Banft sold by George Is. Ward, of Sioux City, Ia., for $\$ 2,105$ to M. F. Jones, of Williamsville, "Ill.

1903, June $12 \mathrm{th}$. - New York auction sale f working coach horwen realized an average of $\$ 707$ per head. The horses had been used in working the coach Pioneer between Nely York and Ardsley. Among the buyers were Ifarry Payne Whiney, G. G. Haven, Jr., and other well-known whips. The former pald the top price, $\$ 4,750$ for one pair. Severa sold singly at $\$ 1,000$ to $\$ 1,800$.

1903.- At Chicago, June $13 \mathrm{th}$ and $14 \mathrm{th}$ Canadian shorthorn sale. IV. C. Edwards, of Rockland, Ontario, forty-five head; average, \$448.90; John Dryden, of Brooklin, Ontario, nineteen head; average, \$565; M. H. Cochrane, of Hillhurst, Quebec eirhteen head: average, $\$ 683$, Top price, $\$ 2,110$, paid by W. H. Dunwoody, of Minneapolis, Minn. for the bull Imp. Golden Mist, 182,753. Including fifteen females by Geo. Harding k Son, of Waukesha, Wis., averaging $\$ 502$, the grand average for ninety-elght head was $\$ 536.40$.

1903. June 14th, One thousand dollars paid for a peony called Jenny Iind, named after the Swedish Nightingale. Sold by C. Betschler, of Canal Dover, O., to C. W Tard, of Queens, N. Y. This peony blossoms

1903, June.-Kansas City Stock Yards flooded by high water. Business suspended fourteen days

1903, June 15th.-Amour Packing Company commenced operations at the St. Louls National Stock Yards.

1903. June 15th-St, Joseph Stock Yards received 10.028 fresh cattle, the largest cattle receipts for one day on that market. 1903, July,-Ilistory of Agriculture by Dates first issued by Philip $H$. Hale, St. Louis, Mo.

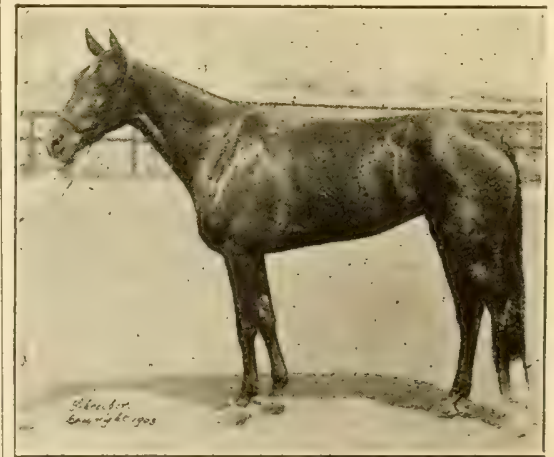

I,OU DILLON, 1:58 1/2,

1903, July 11th.-At Cleveland, O., Lou Dillon broke the world's record for trotting mares by one-fourth of a second, going the mile in $2021 /$ It was the second fastest mile ever trotted. Cresceus alone having a better mark. Millard Saundens was in the sulky, and two runners accompanied the little mare around the track. She reached the first quarter in $0 ; 31 \frac{1}{4}$, and the half in 1.0134

1903. July 18th.-The first bale of newcrop Texas eotton was sold this day at the Galveston Cotton Exchange for $\$ 136$, and bought by C. Fisenburg. It weighed $4 \% 0$ pounds, and the price was a little less than pounds, and the price whas little ras Tapata per pound. Tapata county, one of the southern Rin Grande counties, where cotton was not
raised before this year.

1903, August 17 th.-Record run of cattle on the Chicago market; 36,727 head received this day. 
1903, August 19th.-At New York, Dan Patch broke the world's pacing record at Brighton Beach by going a mile in 1:59, flat. The fractional times were: Quarter, $0: 29 \frac{1}{2}$; half, $0: 5 \mathrm{~S} 3 / 8$; three-quarters, $1: 291 / 4$ The best previous record was 1:591/1, held jointly ly Dan Patch and Star Pointer.

1903. - In this year the United States and Canada made a record by canning $10,679,809$ cascs of tomatoes, each case containing cans.

1903, September 9th.-At Syracuse, N. Y. the world's record for trotting geldings was broken by Major Delmar, its holder clipping a second from his own mark and threelluarters of a second from the former world's record established by Cresceus. Alta P. MeDonald drove the gelding. Time by

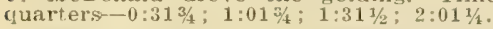

1903, September $2 S t h$-Cattle receipts at Chicago the largest on record for one day44,445 head.

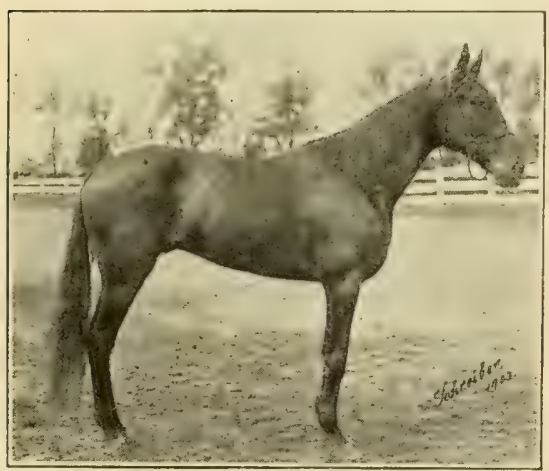

MAJOR DELMAR, 1:593/4.

1903, October 10tin-At Lexington, Ky. Major Delmar reduced trotting record, ex hibition mile to wagon, to $2: 03 \frac{1}{4}$. Immediately after the performance of Major Delmar, Lou Dillon, driven by her owner, C. I G. Billings reduced the record to $2: 01,4$ Time Quarter, 0:31; half, 1:01; threeguarters, $1: 30 \% \frac{1}{4}$; mile, 2:01\% .

1903. October 10th.-Charmante of the Gron, 14,442, Guernsey cow, owneil by $\mathrm{H}$ McK. 'Twombley, finished the year's test, snaking a year's record of $11,8743 / 4$ pounds of milk, which contained 676,46 pounds butter-tat, which, being churned and salted, would make 789.2 pounds of merchantable hutter for the year.

1903. October 24th. At Memphis, Tenn. Tou Dillon, the peeliless trotter, owned by C. K. G. Billings, of Chicago, and driven by Millard Saunders, again proved her right to the proud title of Queen of the Turf by trotting a mile under adverse conditions in the remarkalle time of $1: 581 / 2$. The daughter of sidney Dillon was paced by a runner, and another followed closely to urge the mare to a supreme effort A strong wind from the north swept down the back stretch, and it was not expected that she could ent anything from her former wonder ful record. The quarter was reached in s0 seconds: the half in $0: 59 \frac{1 / 2}{2}$ the third quarter was passed in $1.28 \mathrm{j}$. and the gallant little mare passed under the wire in 1:5 $3 \%$. The timers were Bud Doyle, Fred Hartwell and John Dickerson, and the watches all agreed to a fraction.

1903,--Segis Inka, 36,617, Molntein-Friesian row, sold at Averill \& Gregory sale to Ir. $W^{7}$. N. Landon, of Syracuse. N. Y., for $\$ 1,600$ highest-nriced female of this breed at auction since $188 \mathrm{~s}$.

1003, October 2.th. - At Narragansett Park. Prince Alert clipped a quarter of a second from the world's pacing record for a half mile. The Prince was driven by Mart Demarest.

1903, Uctober 24 th-At Memphis, Tenn. Dariel, a bay mare, by Alcander, driven by A. MeDonald, paced a mile in $2: 00 \frac{1 / 4}{\text {. The }}$ former pacing record for a mare was held Fanny Dillard, 2:033,

1903, Octolier 24th.-At Memphis, Tenn., Equity and The Monk, from the stable of Mr. C. K. G. Billings, of Chicago, were sent a mile against $2: 1214$, trutting to pole record. The two horses were driven by Mr. Billings in faultless style, and passed under the wire in $2: 091 \%$.

1903. Octobcr 27th-Major Delmar trots in $1: 5,3 / 4$, establishing the world's gelding receril.

1903 - "Country Iife in Amerlea" for this year says that the annual sale of cut roses in the United States amounts to about $\$ 6,000,000$; carnations, $\$ 4,000,000$; violets, -750,000: and chrysanthemums-a shortseason crop--\$700,009. The annual production is estimated at $\$ 100,000,000$ each for roses and carnations and $\$ 50,000,000$ for violets.

1903, December :1st.-D. Rankin, of Tarkio, Mo., eoncluded a purchase of 3,500 stock cattle and feeders on the Kansas City market, shipping them out in 125 cars. Considered a record purchase of this character

1903, December-Chicago International Live Stock Exposition. Champion beef steer the grade Hereford steer Challenger. Weight, 1,750 pounds. Fed and exhibited by the Agricultural Fxperiment Station, Lincoln, Nebraska.

1903. - Grain production of the year: ,244,177,000 bushels corn, $637,822,000$ bushels wheat, $784,094,000$ bushels oats, 131,861 bushels barley, 29,363 bushels rye.

1903. - Highest whent, September, 93 cents: highest corn, July and August, 53 cents highest oats, July, 45 cents. Lowest wheat, March, 701/4 cents; lowest corn, December, 41 cents; lowest oats, March, 31 cents.

1904, January 1st,-United States Department of Agriculture estimate of number of farm animals: $17,419,817$ milch cows, 630,144 sheep, 16,736,059 horses and 2,757,16 mules.

1904.-I'romising new fruits mentioned and illustrated in Year Book of the United Slates Department of Agriculture: Bloomfield apple, Doctor apple, Rossney pear, Millennial grape, Perfection currant, Delmas persimmon.

1901, January 11 th.-Iargest receipt of cars in one day at the Union Stock Yards, hicago, $3.29 \mathrm{~S}$

1904, March 1st.-Auction sale of jacks and jennets by $I_{6}$. M. Monsees \& Sors at Smithton, Mo. Top price for a lack, $\$ 1,500$ : average for twenty-nine head, $\$ 581$

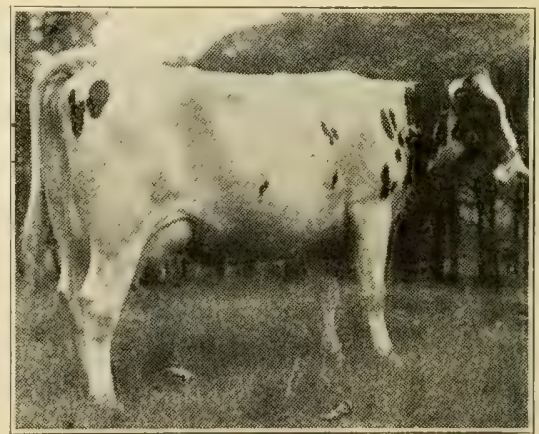

MISSOURI JOSEPHINE SARCASTICDAUGHTER OF MISSOURI CHIEF JOSEPHINE, Milk record for six months, as a twowyear-old: 7,037 pounds, This is 334 pounds higher than her dam's record at the same age. Bred and owned by the University of Missouri.

1904, March 24th.-In the open market at Chicaso a roan Shire draft relding was sold for the record price of $\$ 660$. According to the Drovers' Journal, this champion roan 
drafter was consigned by William Gray, of Mechanicsville Ia., and purchased by Armour E Co, at the highest price paid iu the open marlcet for a drafier for commerand weinhed, 210 pounds. This chanpion Arafter was brcal by Jerry Terrill of Oxford Mills, Jones county, lis. and was sired by the importcd Shire stallion Ringmaster, ani Whose dam was sired l,y the imported Shire the promise of his high quality by winnim the blue ribbon in his class at the internationil live stoek strotir

194. April 1st.-Geo. H. Northrup of liacesille. Washington county, New Jork, Vinorea fowle for $\$ 3,100$. wreting the world's reeord in poultry sales. Vintor, the lirst-prize cock at ('hicago, brought si,ool and Headlisht. $\because d$, the second-prize cock at Chicago, bought \$5014. The huyer was Henry Germiany.

1901. - Louisiana l'urchase Exposition opened April ":uth and cloted December ist. Live stork exhilit the greatest ever recorden in history.

1904, June 15th.-The St. Inuis National Stock Yards received 31! cars, S.S57 head, 'Pexas and southern attle a reorrd day in ruarantine cattle

190: Tune isth- It Clevelana O Mr. 15. C. Billings roike charlie Mac a mile fo mallile in an effort to lireak the amateur World's record of $": 191 / 4$. T'he record was

ig0t-At the Louisiana Purchase Exposiion, through the resourcefulness and eriergy of $\mathrm{Mr}$. Will B. Otwell, 8,000 Illinois farmers boys exhibited a grand pyramid, consisting of 1,000 small pyramids, each containing ten ears of pure-lired corn.

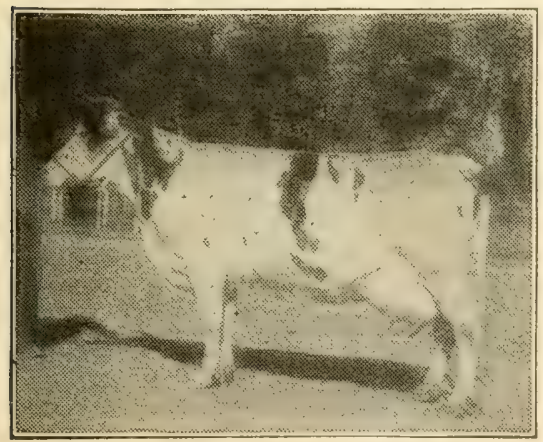

HOLSTEIN COW-JOLIE JOHANNA. A ten years old, in the ninety-day demonstration test at St. Louis, she gave 5,064. pounds of milk and 169.99 pounds of butterfat, equivalent to 212.48 pounds of butter, an average daily yield of 2.36 pounds of butter She was first-prize cow at the St. Louis World's Fair, champion senior female at the IVorld's Fair, and grand champion female of the Holstein breed at the same Fair. Her olficial test made on the World's Fair Ground at St. Louis was 544.6 pounds of milk, 19.61 pounds of butter-fat, the equivalent of 23 pounds and 14 ounces of butter in seven consecutive days. JOLIE JOHANNA is otwned by the State Agricultural College of Coloraclo.

1904.-The stallion Carmon, 32,917, American Trotting Register, 16 hands; weight, 1,200 pounds in fair condition, was selected 1,20 pounds in fair condition, was selected American carriage lorses. Carmon was bred by Hon. Norman J. Colman, of St. Louis, Mo

1904. June 1Sth, - At Chicago, without feeling the touch of the whip or spur and running entirely on his own courage, Highball, the three-year-old colt which IV. M Scheftel brought to Chicago from the Fast, won the Ameriean Derby at Washington Park. The time, $3: 33$, equals the best time ever made for this event. 190h, June 18th. At Clevpland, O., before

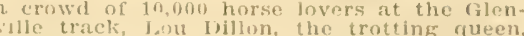
iriveit by her owner C K $C$. Blllings, was sent at mile (o wazon to bent the amateut record of $2: 10$. The mar\% made the distance in $y \cdot 11 ; 16$. The last queter was made in

1901, June 25th.-Worid's Fair Trotting Iandican (at St louis Fair Grounds) mile nd a quater, won by Colonial Girl. Time 19)1, reth. The largest one-

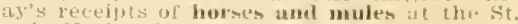

1901, September 29 th.-Gireat sale of hunters and hommds, the property of Foxhat P. Keene, at the stables of Van Tassell t Leamey, New Fork (:ity. Light American I) red cross-country horses sold for $\$ 20,300$, an itweratge of $\$ 2,5: 3$ yer head, and a pack of

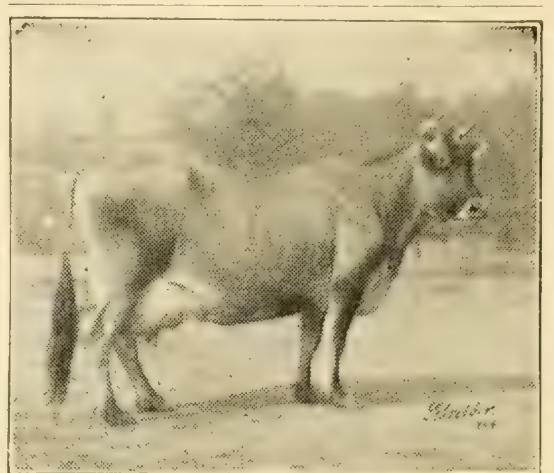

JERSEY CON-LOTETTA D. AS champion cow of all breeds in the St: Louis Fair Contest. LORETTA $D$. is the latest grand champion of the Jersey breed. In the contest of 120 days this cow gave $5,08 \%, 7$ pounds of milk, 4.8 per cent, fat, yieldins 280.16 pounds butter-fat, equivalent when salted to 330.04 pounds of commercial butter.

1904, Oetober 13th,--End of dairy cow demonstration at World's Fair. St. Louis. Loretta D., 1!1.70S, owned by the estate of ir. S. Fadd, Portland, Oregon, winner in contest. In 197 days Loretta D. produced 214.7 pounris of milk, a daily average o 49.3 vounds, siving $\$ 14.64$ pounds of butter fat. equal to 490.12 pounds of commercial mittel, an alerage of 2.62 pounds of butter Loretia $[$. is a high-bred Jersey

1964, October 21st.-The Monk and Equity trot a mile in $2: 073 / 4$ at Memphis, Tenn. establishing the world's team record.

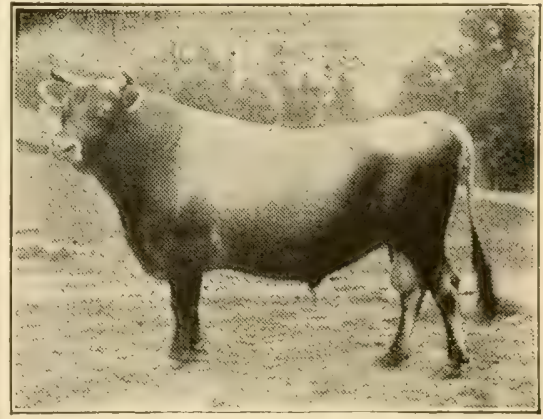

JERSEY BULI SILVERINE COOMAS SIE. This bull had the distinguished honor of heading the champion Jersey herd at the Louisiana Purchase Exposition. He was firstprize winner wherever shown and never beaten by any bull of his age. Presented here as a typical Jersey bull of the highest quality. 
1964, October $24 \mathrm{th}$.-At the Chicago Linion stock Yards. Mr. I. M. Newgass made a record by selling a matched pair of bay uraft geldings, the team weighing 4,450 pounds. The sale was made to Mr. H. K. Bloorgood, ot Poston, and the price

1,000 for the pair.

1961. Octolier 25th._At Hemphis, Tenn. Jrince birect and Morning Star pace il '2:06, making world's amateur team recor.l, diriven by (" K. G. Billings.

1904, Octoler 26 th.-Dan Patch establishe world's pacing record at Memphis', Tenn. reducing the mark to 1 .

1904, December--Chicago International Live Stock Exposition. (irand champion best aniual the therdeen-Anzus steer Clear Jake Jute, fecl and exhibited by the Minnesota agricultural Experiment station. Live weight thirty-eight months, 1,895 pounts.

1904.-Grain production of the year: $2,467,481,000$ bushels corn, 552,400,000 bushels wheat, $894,595,000$ bushels oats, $139,749,000$ bushels barley, $27,242,000$ lushels rye.

1901.-Largest receipts of horses and mules at any market in one year, 181,341 hearl, received this year at the St louis National Stock Yards.

1904.- Highest wheat, September, October and December, $\$ 1.22$; highest corn, November, $581 / 4$ cents; highest oats, February, 46 cents. Lowest wheat. January, $81^{1 / 4}$ cents: lowest corn. January, $423 / 4$ cents: lowest oats, October and December, ¿s $1 / 4$ cents.

1905, January 1st,-United States Department of Agriculture estimate of number of furm animals: $17,572,000$ milch colvs: 43,669,000 other cattle, $47,321,000$ hogs, 45,170 000 sheep, $17,058,000$ horses and $2,889,000$ mules.

1905.-Promising new fruits mentioned and illustrated in the Year Book of the United States Department of Agriculture: Virginia Beauty apple, Carson apple, Crocker pear, Everbearing peach, Golden plum, Riley, Scioto and Pringle Damson plums, Trapp Avocado pear, Eulalia Loquat.

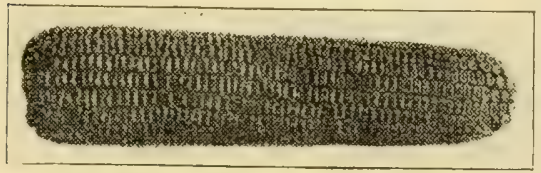

Grand champion ear of corn.

1905. - At the meeting of the Iowa Corn Growers Assuciation held at Amos, Ia., in Jañuary, an ear of corn grown by $\mathbf{M r}$. $H$. J. Ross, of Farragut, $\mathbf{I a}_{\text {, , was declared the }}$ srand champion of the show. It was sold at auction and was bought by Jno. ' $\Gamma$. Alexander, of Chicago, for eleven dollars.

1905, February. $\rightarrow$ The National Farmer and Stock Grower, of St. Louis, Mo., started the agitation against the high rate of interest charged upon farm loans,

1905. March 6th.-I.argest receipts of liorses in one day at the Union Stock Yards, Chicago, 2,177 head.

1905, Marci 11 th-Largest receipts of horses in one week at the Union Stock Yards, Chicago. 4,768 head.

1905. March $11 \mathrm{th}$--Largest receints of horses in one month at the Union Stocis Yards, Chicago, 18,448 head.

1905, April 17th.-C. M. Rand, a horse dealer, sold the highest-priced car-load of iraft horses on the Kansas City niarket to this time. The car-load contained sixteen head that weighed 1,600 to 2,150 pounds, and brought $\$ 230$ to $\$ 275$, or an averase price of $\$ 251.51$. The horses were shippea in from lowa.

1905.-In a threc-mile runuing race at Oakiand, Calif., Saturday, April Sth, the American record for that distanee was low ered by Fille, a four-year-old son of $\mathrm{St}$. Carlo, owned by C. Stubenford. Carrying 13 pounds, Elie refeated Dr. Leggo, the favorite, Veterano, Orchan, Parney Dreyfus, Fly-
ing Tornado and Grafter, and covered the three miles in $5 \cdot 22$, the best previous time having heen Drake Carter's record of 5:24, made at sheepshead Bay in September, 1834.

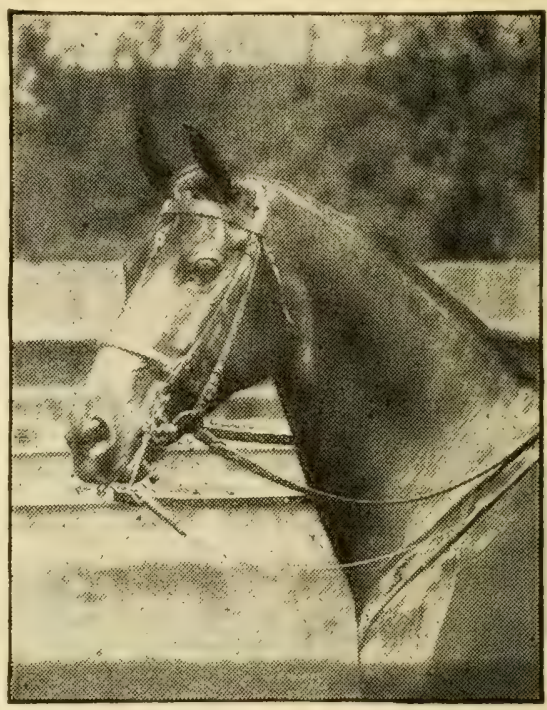

HEAD OF MY LADY DAINTY-Typical New York saddle mare of the best class.

1905, April.-M, H. Tichenor \& Co., of Chicago, sold May Morning, a golden chestnut saddle horse, five years old, fifteen hankls high, to J. H. Monre, for $\$ 3,650$. This was at a New Fork auction and reported. to be the highest price paid for a saddie horse on the auction block.

1005, April 27th.-A pair of big mules sold for $\$ 5 t 0$ at the St. Iouis National Stocic Yards by Campbell \& Reid and Western Sale Stables Company reported as being the highest-priced pair sold in the open market.

1905, May 21st.-Lurgest receint of calves in one week at the Union Stock Yards Chicago, 15,910 head.

1965, Julv,--An arbitration award by the Kink of Italy respecting the inglo-1'ortuzuese irontier in Africa, apportions the last piecs of vacant or unaporopriated land on that continent. It also awarded the last viece of land arailable for colonization in the known world, Africa being under government control.

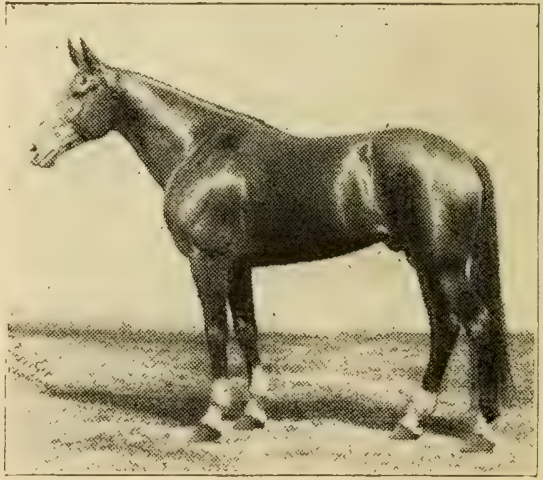

JOE PATCHEN, 23:011/1-Black horse, by Patchen Wilkes. Holcler of paeing recori for fastest two-heat race by a stallion 2.03 $2: 023 / 2$. Sire of Dan Patch, champion 
195,. May.-Two of the bent mules ever seen at St. Louis were marketed by Frank ripping big pair, weiching They were a nounds, and were sood all over. The best noundence of this was that they brount sint one of these mules was what was properly designated "a cracker-jack." She was said "Sh " by every dealer to be the best mule they had ever seen, not in a month, or it year, lut their whole experience. She weighed 1,690 pounds, and had the shape, the Tuatity, the stvle, home, font and everything dealers hid $\$ 3: 5$ to $\$ 330$ for her alone. The mules were hought hy Mr. I'latter from l'en Brovles, of Chula, Mo.

1905. May.--Largest receints of ralves in one month at the Union Stock Yards, Chicago, 62,74" head.

1905. August,-Reciprocity Conference at Chicago for the purpose of encouraging rade in farm and ranch products with foreign nations.

1905.-In the month of July, New York received 314,560 vackages of butter, the largest arrivals to that time.

190\%. August 17th.-At Decatur, Ill.. The Broncho paces in $2: 03 \frac{1}{4}$, making it world's tecoril for mares.

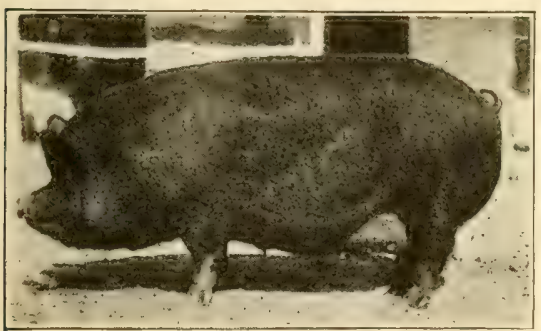

QUEEN ESTHER, 3,038-ESSEX SOIV. First-prize winner and sweepstakes sow at the St. Louis Fair, 1902 , the only time shown. Her pigs were first-prize winners in 1901. also in 1902. Bred and owned by peter Miller \& Son, of Belleville. Ill.

1905.-- It Spingfield, Ill., on November $2 d$, a sale of shire horses was held by J. S. Wrisht and Storey \& Son. The tive stallions averaged $\$ 117$, and the top price was $\$ 975$, paid by Wm. Spears, of Tallula, Ill., for iond Eob, a six-year-old stallion, sired by bandy Dick. The best price for a female Was $\$ 413$, paid by $C$. G. Spence, of Assumption, Ili, for Forest Belle, a four-year-old, sired by Rampton.

1905. September $30 \mathrm{th}$-During the year ending on this day, the Guermaty cow Yeskit sunheam gave $14,9 \pm 0.5$ pounds of milk averaging $5.7 t$ per cent. fat, equal to 857.15 pounds of pure hutter-fat and equivalent to $1,0 \theta^{\circ}$, pouncls of merchantable butter, this leine the world's otlicial butter-fat record made under wublic supervision.

190.5. Octoher 7 th. - In a contest against time the famous champion harness horse, the stallion Dan Patch. established world's record by maeine in 1:501, Lexington. $K \mathrm{y}$.

1905, October.-Largest receipts of sheen in one month at the Union stock Yards, Chicago, 690,956 head.

1905. November.-The Eastern stable of show horses belonging to Mirs. J. B. M. Grosvenor being sold at auction, brought a total of $\$ \$ 4,250$ for twenty-eight head, which is in average of $\$ 1,937.50$ per head. The carriage team. The Baron and The Presicent, sold to Dr. J. G. Lyman for $\$ 8,000$. Pow IVow and Torriahawk, another pair, sold for $\$ \$, 500$ to J. E. Denny, of Pittshurgh, Pa. The high price - for a single animal was $\$ 2,800$. pair for Petroleum, a $15 \frac{1}{2}$ black gelding, hought in for Mrs, Grosvenor.

1905. At New York, on November 22d, Crespeus, the famous trotter, was sold in Madison Square Garden for $\$ 21,000$ to M. IV. Savage, of Minneapolis, Minn, who also owns
Dan I'atch, frion, and other famous horses. The only nther bidder was P. 11. Meciuire of New York, who oftered $\$ 20,000$. Nearly (10) Deople were present to see the sale.

1905.--During the year the pure-bred itock sales at the Chicago Union Stock Yards amounted to thirty-five, at which 584 heail of e'ttle were sold at an average of \$1,1.9f per head. The shorthorns were 120: average, \$215,25. Herefords, 142; average \$137.20: Aberdcen-Anfus average, \$156.98: and Galloways, fity-six head; averafe,

1905. Decemher-International Iive Stock lixprition at Chicazo. Campion beef steer Blackrock, Aberdeen-Angus, two-year-old, weighing 1,650 pounds. He was ferl at the A gricultural College and was sold at

1905.- The mannine of corn in the Uniter States and Canada reacheri a total of 13,418,6fis cases, each case containing two dozen standard cans. Iowa led the list, 1905, December 5th.-At Van Tassell \& Kearney's action stables, New York City, five hundred thoroughbrel horkes were solil under the hammer when Watercress sold for $71,000$.

1905. Grain production of the year $2,707,993,1000$ bushels corn, $692,979,000$ bush. 551,000 bushels barley and 28,48 fi, 000 busheis rye.

1905.-Highest wheat, February, \$1.24: highest corn, May, $64^{1 / 2}$ cents; highest oats, July, $341 / 4$ cents, Lowest wheat, August, $77 \%$ cents; lowest corn, January and December, 40 cents: lowest oats, september. cents.

1905.- - Momising new fruits mentioned and illustrated in the Year Book of the United States Department of Agriculture: Magnate apple, Oliver red apple, Rabun apple, Early Wheeler peach, Banner grape, Josephine persimmon and the Chappelow Avocado or Tropical pear.

1905 - - Largest receipts of horses in on year at the Union Stock Yards. Chicago.

1906, January 1st.-United States Department of Agriculture estimate of number of farm animals: 19,734,000 milch cows, 47,068.ino other cattle, 52,103,000 hogs, 50,632,000 sheep, $18,719,000$ horses and $3,404,000$ mules.

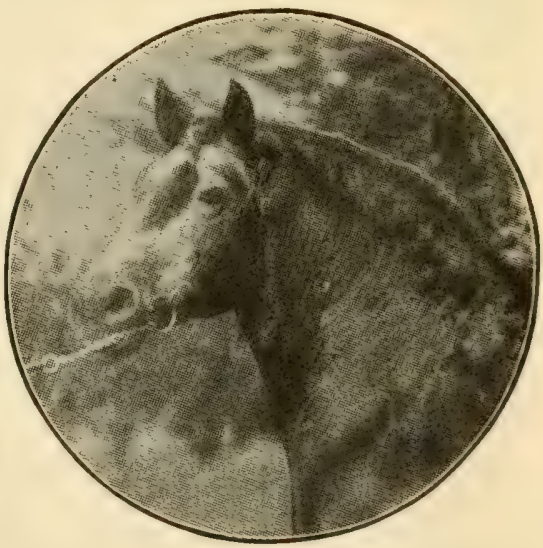

THIE PERCFERON HORSE from LaPerche France, is the most numerous breed of draft horses in the United States.

1906.-The draft-horse sale held at Bloomington, Ill., January 4 th and 5 th. under the management of C. IV. Hurt, resulted in a general average of $\$ 36 " 95$ for fifty-thlee head. The eighty-nine stallions average $\$ 424.25$ and sixty-five mares averaged $\$ 311.55$. The Percheron stallion Prurent. sired by Hercules, sold at $\$ 1,650$ to J. C. Good, of Flannagan, Ill,; Germain, sired by Odeon, sold for $\$ 1,040$ to Emanuel Cross, 
of Adrian, Mich. and Pedroe, sired by Sansonnett, 2d, sold to TVm. Rumney \& Sons, of Somonauk, Ill., for $\$ 1,005$. The top-price mare, Colly P., sired by Powerful, sold to $11 \mathrm{~m}$. Zumdahl, of Forrest, Ill., for $\$ 635$.

1906, January.-Ohio Chief, 8,727, a Duroc-Jersey boar, was sold by S. E. Morton, of Camden, Ohio, for $\$ 2,000$ to Mr. B. J. Harding, of Macedonia, Wis,, this remresentboar Ohio Chief was bred and raised by lir. Morton and was first-prize boar, two years olct and over and reserve seniot champion at the Louisiana Purchase Exposition.

1906, January. - In this month the St. Louis National Stock Yards received "9.831 horses and mules, a world's record.

1906, February $2 \mathrm{~d}$.- At a public sale of Buroe-Jersey swine, Helen Blazes, III., a daughter of Tip Top Notcher, out of Helen Blazes, bred by H. E. Browning, of Ripley, III., was sold for the record price of $\$ 1,000$ to J. Coy Roach, of Girard, Ill.

1906. On February 5th, at Omalia, Mark M. Coad, of Fremont, Neb. sold Americanbred Percheron horses under the management of John S. Cooper. At the sale seventeen two and three-year-old stallions sold for $\$ 10,100$, averaging $\$ 594.15$, and eleven mares brought $\$ 3, \$ f, 0$ an average of $\$ 351$, while the twenty-eight head averaged nearly $\$ 500$. The top price was $\$ 1,000$, paid by M. B. James, of Aurora, Neb., for the stallion Albion, and F. K. Miller, of Hamptop-priced mare.

1906. - At a sale of shorthorn cattle held at Perth, in Scotland, Lord Lovat sold the bull Broadhooks Champion to Mr. Miller, an Argentine exporter, for 1,500 guineas English money, equal to $\$ 75,000$ in American money.

1906, February.-The grand champion fat steer at the Western Live Stock Show, a yearling Shorthorn, weighing 1,150 pounds, was sold to J. D. Miller at 33 cents a steer in Colorado. The steer was fed and exhibited by the Colorado Agricultural College.

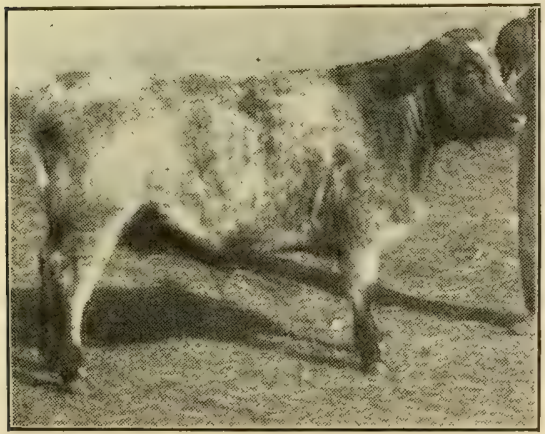

SUSAN CUMBERLAND-Junior champion Shorthorn female at the American Royal Show of 1909. Exhibited by D. R. Hanna, of Ravenna, Ohio.

1906.--At Vandalia, Ill., February 25th, G. G. Council sold forty-two head of hogs at a public sale at an average of $\$ 258$ per said to be the world's record. Another high price was set in the sale of Baron Duke, piftieth, which brought $\$ 1,600$. This hog was sold to IV. S. Corsa, of Whitehall, IlI.

1906. - In Mareh some public sales of Poland-China swine were at strong prices. E. H. Ware, at Douglas, Ill., sold fifty-four head at an average of $\$ 119.33$, with a top price of $\$ 380$. E. L. Jimison, at Oneida, Ill. sold fifty head at $\$ 116$ per head, with $\$ 910$ the top price, naid by Frank Waigemuth, of Elgin, Ill, for Keep Sake, a Keep On hoar: J. C. Hanna, of Middletown, Ta. sold with top price of $\$ 320$. Linc Lukens, of Disko, III sold sixty head at $\$ 104.33$ per head, the iop price at the sale being $\$ 600$.
1906, March.-A notable sale of mules was effected at Atlanta, Ga.. by Herren. Bradbury \& Co, There were twenty head. averaging $\$ 452.50$. One pair of show mules included in the lot brought $\$ 1,150$ and were Trouy, and Molly, World's Fair champions. lt was a recora price for mules.

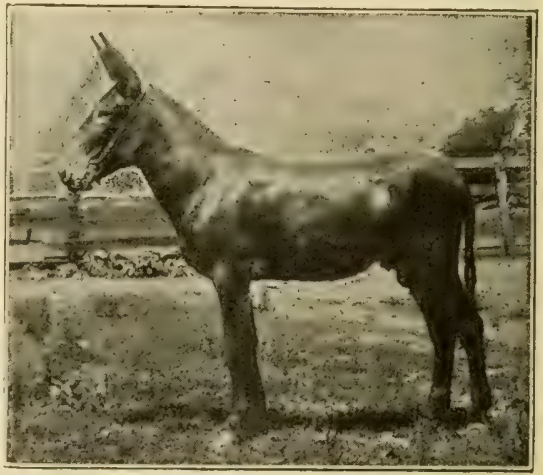

ORPHAN BOY-Grand champion jack at the Louisiana Purchase Exposition, 1904 Exhibited by L. M. Monsees \& Sons, of smithton. Mo.

1906, March 6th.-At the sale of jacks and jennets held by L. M. Monsees \& Sons, of Smithton, Mo., several records were broken, as follows: Highest-priced jack at auction. Good Nature, two years old, sold to $\mathrm{Wm}$. Van Sweringen, of Holton, Kas, for $\$ 1,600$. Highest average for jacks, $\$ \$ 56.30$ per hear for thirty head, and largest total amount of sale, $\$ 31,990$. The jennet average was \$169.72 for twenty-seven head. High Style, a four-year-old jack, sold to the Goodrick Stock Farm, of Eldon, Mo., for $\$ 1,510$; all Beston, a three-year-old, sold for $\$ 1,42 \%$ to J. IV, Stokey, of Gansing, Kas, for $\$ 1,425$. The best price for a jennet was $\$ 565$ for Missouri.

1906, March 7th.-At Green Bay, Wis., the Hagemeister Stock Farm sold fifty head of Percheron horses for an average of $\$ 501.50$. The sixteen stallions included three at $\$ 1,000$ and upward, and the average was $\$ 612.50$; and thirty-four mares averaged $\$ 501.50$. The top-price stallion was $\$ 1,250$, paid for Eclaireur, a six-year-old, sold to Con. Keef, of Depere, Wis. The best price Milure was

1906. March 19th.-A. J. Lovejoy \& Sons, of Roscoe. Ill. sold the Berkshire boar Masterpiece, 77,000, for $\$ 2,500$ at private sale, the purchaser being IV. S. Corsa, of hitehall. Ill.

1906, April.-At a combination sale of trotting horses held by the Biair-Baker Horse Company, of Indianapolis, Ind.. Grace A., $2: 121 /$ by Anderson IVilkes, topped the market for trotters at $\$ 5,000$ while the grand young mare, Alfalfa, $2: 11 \frac{1}{1}$, by Argnt Wilkes, brought $\$ 3,800$, the top price for pacers. Numerous sales were macle between 1,000 and $\$ 2,000$.

1906, April 3d-At the St Louis National Stock Yards the McFarlane Commission Company sold twenty-one head of mules for Ratz Rros., of Red Bud, Ill., for an average of $\$ 237.50$, the record price for a load of mules sold on consignment in the market.

1906. May 1st.-Largest receipts of calves in one day at the Union Stock Yards, Chicago, 9,284 head.

1906. May 17th. - At the annual Spring Show held on the Island of Jersey the cow IKarank, the winner of the English Jersey Cattle Society gold medal, establisher : butter record for the island. She made three pounds six and one-half ounces of rater in twenty-four hours, the best ever Karank is owned by Mr. G. L. Gruchy: was seven years old and 123 days in milk. There were eighty-one entries in the contest. 
1906, May 15th-Close of olficlal year in testing Holntein-Friesian cows for advanced registry. During this oflicial year 1,545 Holstein-Friesian cows and heifers of all ages were oflicially tested for a period of seven consecutive days or longer, producing for the seven consecutive days $581,95: 5$ pounds of milk, containing $19,701.2$ pounis butter-fat, and showing an average of 3.39 ller cent. fat. The averase weekly production for each animal so tested was 376 . pounds milk, containing 12.75 pounds butter-fat, equivalent to 53.5 pounds milk. or over tiventy-six quarts daily, and nearly: lifteen pounds of the best quality of butter per week for each cow.

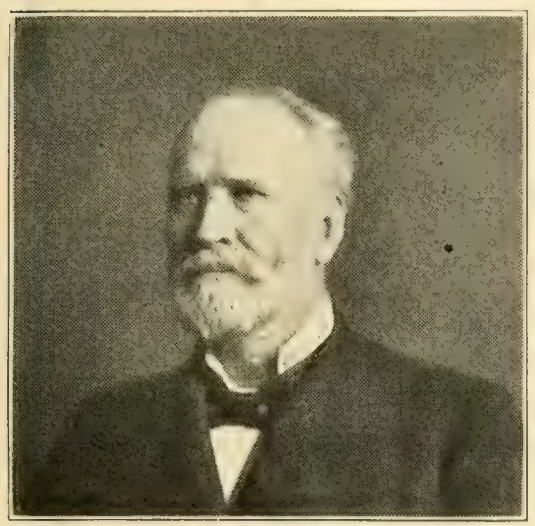

HON. JAMES WILSON, of Tama county, Iowa, United States Secretary of Agri culture. He served the longest term of any Secretary of Agriculture.

1906. June $19 \mathrm{th}-21 \mathrm{st}$. The dispersiou sale of the herd of shorthorn cattle established by G. M. Casey, of Clinton, Mo., and later known as the Tebo Land and Cattle Company herd, took place at Kansas City, Mo. The result was an average of $\$ 308.60$ for $166^{\circ}$ females, an average of $\$ 1,1,01.35$ \$i: 77.75 for 177 head. The bulls included the rrand champion Choice Guods, 186,812, sold grand champion Choice Guods, 186,812 , sold at $\$ 5,500$ to Howell Reese, of Pilger, Neb.
Two sons of Chnice Goods sold at $\$ 1.500$ each. The top price for females was the imported cow Marenso's Lavender Countess with heifer calf hy Choice Goods at foot and sold for 82,150 to $C$. E. Leonard \& Son. of Bell ir. Mo. The grand champion cow Ruberta also sold to Howeli Reese at $\$ 1,3$ : Thirty-one of the get of Choice Goods sold at the sale for $\$ 18,731.85$. The total amount realized at the sale was. $\$ 63,337$.

1906. June.-De Kolle Creamelle 59.158 , IIolstein cow owned by D. W. Field, of Dutchliand Farms, Montello, Mass., finished it hundred-day milking test, giving 10,017 pourids of milk. 2.84 per cent. fat, or 284 pounds of butter-fat, equivalent to 335 pounis of merchantable butter. This cow is claimed to hold the largest official singlefay milk recorr, 119.4 pounds of milk; the largest seven-day record, 780.3 pounds of milk: the largest thirty-day record, $3,200.3$ pounds of milk; the largest sixty-day record, 6,251 pounds of milk: the largest ninety-day record, 9,4it pounds of milk; and the larcest hundred-day record, 10.017 pounds of milk. The hundred-day milking recoro was nearly equal to twelve gallons of milk per day.

1906. June 99th.-The President signed the bill passed by Congress and introduced by Hon. W. A. Rodenberg, of Illinols, which extends the time of live stock in transit without unloading from a limit of twentyeight hours to a maximum of thirty-six hours. This is to be done upon written request of the owner or person in charge of the particular shipment.

1906. June 29th.-Congress passed a la.w providing for an appropriation of $\$ 3,000,000$ to defray the expenses of enlarged inspretion of American live tock and live stock products, the same to be as formerly under the control of the Lnited States Department of Agriculture. For a long time the bill was delayed through a determined effort to change existing methods and saddle the silaries of the government inspectors upon the stock raisers of the country hy first charging it up to the packers, who would simply buy all stock subject to inspection and clearance certificate, therehy shifting i direct tax of so much per head upon all live stock sold in market to be paid by the owner thereof. The happy result whereby eighty millions of people pay the tax and the government pays and conirols its own inspectors was largely due to the House Conmittee of Agriculture and more especially to Hon. James IV. Wadsworth, of New lark state, to whom the farmers and tock raisers are under great ohllgation.

1906, August.-In England the American eleven-year-old mare Grace Greenlander. $2: 18,14$, reduced the trotting record for three miles in a race and nver a half-mile track io $7: 15 \%$. The fractional time was; Haif, 1:11; mile, $2.3 ;$; one and one-half miles. 12:36; two miles, 4:50; two and one-half ccond mile in $2: 37$ and the third in 3:253\%. Thres other horses started, two of which did not finish. While the third came in about 20 yards behind.

1906.-At Readville, Mass, August 31st, the seven-year-old mare Ecstatic pacel a mile in $2: 0] \%$, reducing the record for a in a race.

1906, August 25 th. - At Galesburg. Ill., the: bay mare The Broncho distinguished herself by pacing a mile in $2: 00^{3}$, establishing the one-mile pacing record for a mare

1906, August 25th.-At Readville, Mass. the paring selding Bolivar, by Wayland $W$ 'I2, dam Belle W., by Conn's Harry Wilkes, negotiated a mile in a race in : $00 \% / 4$, equaling the performance of Prince lert in 1901

1906, August 29th-At Readville, Mass. the gelding My Star reduced the gelding bacing record for a new performer to

1906.-At Libertrville, IIl, September 7 th, the brown stallion Solon Grattan trotted a mile in $2: 10 \mathrm{~s}$ on a half-mile track, thereby

1906, september 1:th,--At Syracuse, N. Y. the hay mare sweet Marie trotted a mile in race in $2: 03 \frac{3}{4}$, establishing a world's

1906. - It Columbus, Ohio, September $17 \mathrm{th}$, the brown mare Italia established a record for a new performer by pacing a mile in $0.04 \%$ a

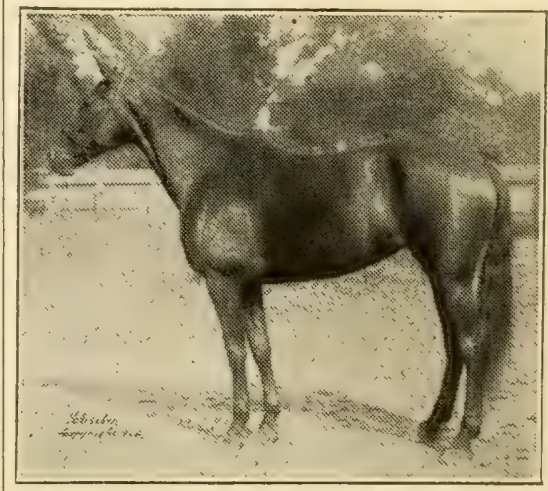

SIVFET MARIF. 2:02.

1906, September 18th.-At Columbus, Ohin the hay filly Brenda Fork, by Moko, pacel a mile in $2: 08: 3$, thereby establishinct record for three-year-old filles. 
1906. September 21st. - At Columbus, Ohio, Siveet Marie, in her ninth year, in a contest against time, negotiated the trotting mile in *:0:. She went the first quarter in $0: 30$; the half in $0: 593 / 4$; and three-quarters in 1:30. Sweet Marie was driven DV Alta MeDonald.

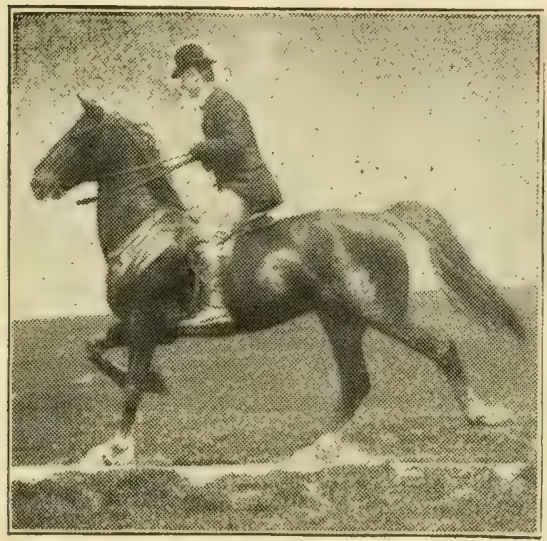

AMERICAN GIRI-A famous prize-winning bay saddle mare, bred by J. D. \& L. B. Owned later by W. J. Roe, of Oshkosh, Wis.

1906. - At Columbus, Ohio, September 21st. The Abhe, black colts by Chimes, trotted a mile in $2: 10 \%$, giving him the joint clain to record marle by Arion in 1902

1906, September 26th.-The First Cow Ifst Association organized in Nevwagn county, Michigan. The plan is that fifteen (ir twenty dairymen form an association and way $\$ 1.00$ per cow por year to help defray the exuerises of the test. A competen person is hired to make the tests. By this means records are kept and the good dairy cowa become known and bred from and the unprofitable cows are sent to the butcher.

1906, October 6th.- Largest receipts of meey in one veek at the Union Stock Yards, Chicaso, 179,490 head.

1906. Octoher sth.-Educational pouitry exlibit car started on the Missouri Pacific Railroad. Was on the road twelve days; storped fifteen times and held eighteen meetings: forty-nine lectures were delivered; 4.080 persons attended the meetings and 15,250 people visited the car. It was in charge of John $T$. Stinson, Agricultural Agent; C. M. Lewellins, Poultry Speaker; Henry steinmesch, Expert Poultryman and Jukge. R. M. Washburn, State Dairy Commissinner, delivered addrezses on dairy sull iects.

1906. Octoher 9th. - At a sale of Westron range hormes held ly Campbell \& Reid and IVestern sale Stables Company at the St. I ollis National Stock Yards, 3,442 horses were sold at auction in six hours, establishing a world's record. J. Tobe Ward and ing a Gors ofliciated as auctioneers. These hinses frought $\$ 17: 0000$. A load of these VVestern range horses sold for $\$ 111,00$ round, the lighest price ever paid for a loar of ranze horses at public auction.

1006, Octoler 16th.-. "First Apple Day" set apart to he celebrated every year so long as time shall last. This was by the American Apple Growers Congress at their annual meeting held at St. Iouis. The Savoy, Ill.; Vice-President, W. R. Willinson. of St. Louis; Secretary, T. C. Walsh, of Hannibal, Mo.; Treasurer, Wesley Greene, of Des Moines, Ia.; Statistician, John A. Stinson, of Springfield, Mo. Apple Day is the thirt Tuesday in October.

1906. October.-The Joseph A. Maxwell Mule Company, of St. Louis, Mo., consigned twenty-seven mules to the opening of the Fiss, Doerr of Carroll Grand Pavilion in New
York City, where they were sold at auction -y electric light on October 25 th at 8 p. m. following the sale of a lot of Percheron horses. They were sold by the pair at a range of $\$ 525$ to $\$ 750$, two pairs of thern bringing $\$ 750$ each. These mules stood it to 17.1 hands, and the average weight was 1,500 pounds, which is 30 pounds more than the average weight of a 16-hand mule.

1006, October '2d.-At Lima, O., George (i,, bay gelding, trotted a mile against time on $a$ half-mile track in $2: 081 / 2$, thereny establishing a world's gelding half-mile track record.

1906. November 7 th, - Near Lawton, Okla., a negro girl from Hill county, Texas, picked 705 pounds of cotton in one day. She was but fifteen years old, and this was claimed to be a world's record for cotton picking, considering age, size and sex.

1906. - On November 29th. Sweet Marie, the famous troting mare, with the record of $2: 02$ was sold at Madison Square Garden for $\$ 14,000$ to $\mathrm{E}$. T. Stotesbury, a Philadelphia banker. Sweet Marie was hred by Frank C. Shumaker, of Los Angeles, Calif.

1906, November $\rightarrow$ Mr. J. Ogden Armour bestoved $\$ 5,000$ annually to be distributer at the International Live Stock Exposition of Chilcago and to be competed for by the State Africultural Colleges. This provides for twenty scholarships to be known in his name. In making the presentation Mr. Armour said: "It is my desire that the recipients of the scholarships be limited to hoys whose parents are unable to give them the advantage of an agricultural education."

1906. November-Jos, A. Maxivell Mule Company, of the St Louis National Stock Yards, sold a pair of five-year-old, sealhrown mules, 17 hands high, the team weighing 3,710 pounds. These were bought by Roliert Harrington and shipped by him to Atlanta, Ga., where they were resold for

1906, December.-International Live Stock cxposition. Grand champion beef steer of the show the pure-bred Hereford calf Peerless IVilton. 39th's Defender, eleven months ld. weight, 975 pounds. The tirst calf warded this high honor. A great example of baloy beet. Bred and fed by F. A. Nave, of Attica. Ind.

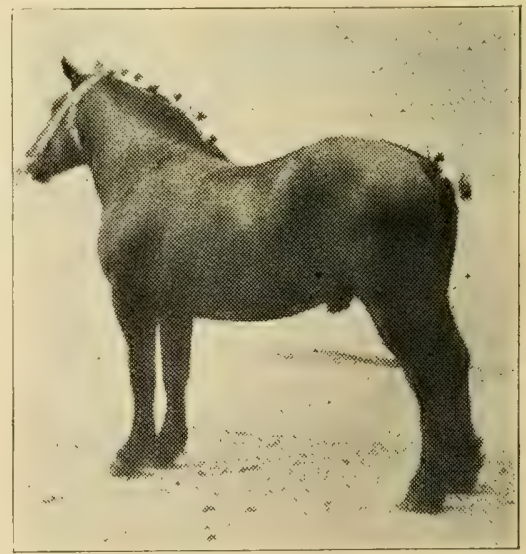

DRAGON-First-prize Percheron stallion.

1906. December,-International Live Stock Expcsition. The two-year-old Percheron stallion Dragon, first-prize winner, sold by McJaughlin Bros, to Mr. H. G. Spohr for the record price of $\$ 5,000$

1906, December.-International Live Stock Show. Frand champion, Aberdeen-Angus bul! Vala's Rosegay. Grand champion female, Eileen Lass. Grand champinn Shorthorn bull. Whitehall Marshall; female Welcome of Meadow Lawn. Galloways-Senior champion, Pat Ryan; female, Myrtle of Avondale. Herefords-Senior champion 
bull, Princeps, 4th; female, Heliotrope Polled Durhams-Senior champion buls. Grover Albotshurn; female, Lady Abliots. lurn. Ized Polls-Senior chamyion bull
Water Boy; female, Jessie.

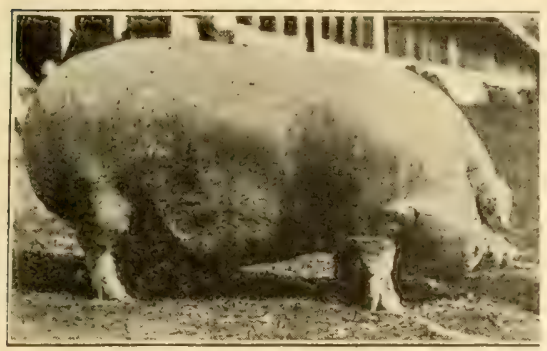

CLARA H.-CHES'PER WHITE SOW Two years old. Champion at the Illinols State Fair, 1905. Exhibited by IV. $\Lambda$. Hoover, of Oskaloosa, Iowa.

1906. December 24th.-From Lonclon England, the first consignment of Finglish apples was sent to the Red sea by G Hodges, of the Covent Garden Market. to Port Sudan. The apples were packed carefully in barrels, containing 120 each, all of the same quality and size. The sorts selected were as follows: Wellingto
heims, Queenings and Greenings.

1906. - Largest receipts of calves in one year at the Union Stock Yards, Chicago, 413,269 head.

1906.-Largest receipts of sheep in one year at the Union Stock Yards, Chicago, $4,805,449$ head.

1906.-Grain production of the year: $2,927,416,000$ bushels corn, 735.201 .000 bushels wheat, $964,905,000$ bushels oats, 178,916 bushels barley and $33,375,000$ bushels rye.

1906.-Highest wheat, May, $94 \frac{3}{4}$ cents; highest corn, June, $543 / 4$ cents; highest oats, June, $423 / 4$ cents. Lowest wheat, August and September, $691 / 8$ cents; lowest corn, February and March. 39 cents: lowest oats, March, $28 \%$ cents.

1907, January 1st.-United States Department of Agriculture estimate of number farm animals: 20,968,000 milch corss, 51,566,000 other cattle, 54,794,000 hogs, 53,240,000 sheep, $19,747,000$ horses and $3,817,000$ mules.

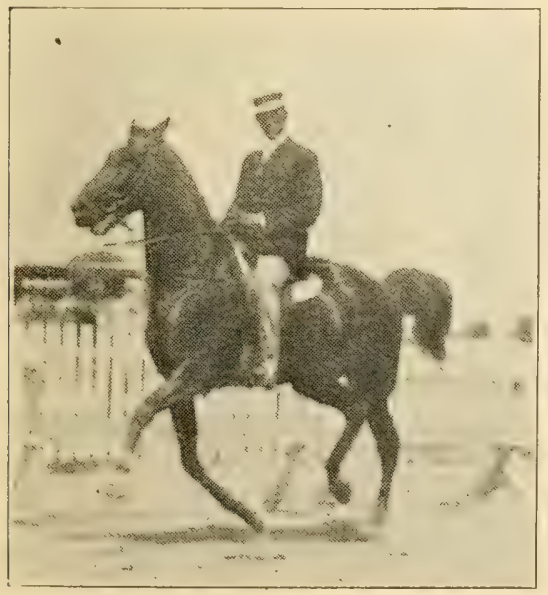

GINGERBREAD MAN-SADDLE GELDING. Winner of six championships. and other prizes in 1911. Owned by T. H. Sonnenburg, St. Louls, Mo. Ridden by Mr. Jno. T, Hook.
1907, January,-Mr. \. C. Van Meter, of Elkhart, Ill., shipped fourteen mules in over Iho Illinois Traction system. It wats the first shimment of the kind over the new road. The load of mules sold at sight to Mr. Adolph IJeiman for \$235, each.-From circular of AcFarlane Commission Company. St. Louis National Stock Yards.

1907.- Promising new fruits mentioned and illustraled in the Year Book of the United states Department of Apriculture Delicious apple, linee apple, latmlier cherry, Miller persimmon, lathy persimmon and Sandershi: Mango,

1907.-In this year $13,070,963$ cases of egg were the total received at New York Chicago, Boston, St. Louis, Cincinnati, Mil Watuke and ban Franclsco. Largest of

190\%.-Ciratin production of the year: $2,592,320,0030$ bushels corm, $031,087,000$ bushels wheat, $754,143,000$ bushels oats, $153,597,000$ bushels barley, $31,5666,000$ bushels rye.

1907.-Wighest wheat, October, \$1.051/4: highest corn, October, $66^{1 / 2}$ cents: highest oats, September, $56 \frac{1 / 2}{12}$ cents. Lowent wheat, January, 71 cents; lowest corn, January,

190\%, March 1st.-Henry Gill, a veteran horse dealer had eleven loads of domestic horses on sale at the Chicago market in one veek. They were all from Iowa.

1907, December, - First National Corn show. Grand prize for the best ten ears of corn won by Mr. L. B. Clore, of Franklin. Ind. with his exhibit of Johnson County White.

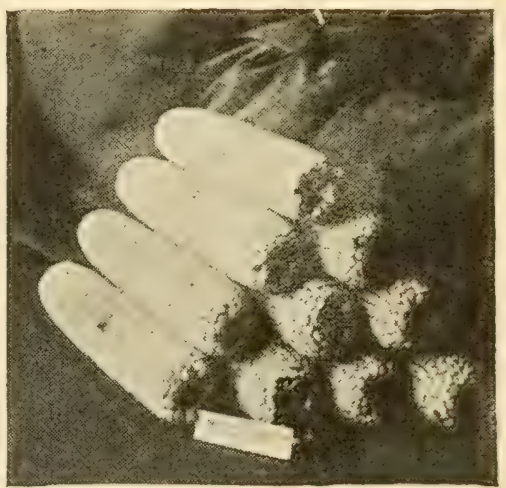

BEST TEN EARS OF CORN exhibited at First National Corn Show at Chicago, 1907. Exhibited by L. B. Clore, of Franklin. Ind.

1907, December, - The National Farmer and Stock Grower, published monthly at St. Louis, Mo, was the first farm paper to ofter quantities of champion seed corn as subscription premiums. The yellow corn used in the campaign was grown by Mr. D. L. Pascal, of Iowa, and the white corn by $\mathrm{Mr}$. L. B. Clore, of Indiana.

1908, January 1st.-United States Department of Agriculture estimate of number of farm animals: $21,194,000$ milch cotws, 50,073,000 other cattle, 56,084,000 hogs, 54,631,000 sheep, 19,992,000 horses and 3,869,000 mules.

1908.-Promising new fruits mentioned and illustrated in the Year Book of the United States Department of Agriculture: Patten apple, Bennett apple, Williams apple, Augbert peach, Champion peach, Eaton raspberry, Peter's Mango, Lonestar and Kavakami persimmon.

1908.-Grain production of the year: $2,668,651,000$ bushels corn, $664,602,000$ bushels wheat, 807,156 bushels oats, $166,756,000$ bushels barley and 31,851 bushels rye.

1908-Highest wheat, May, $\$ 1.11$; highest corn, May and September, 82 cents; highest oats, July, $60^{1 / 2}$ eents. Lowest wheat, July, \$1 $1 / 2$ cents; lowest corn, December, 56 cents: lowest oats, August, 46 cents. 
1909, January 1st.-United States Department of Agriculture estimate of number of farm animals: $21,720,000$ milch cows, 49,379,000 other cattle, 54,147,000 hogs, 56,084,000 sheep, 20,640,000 horses and 4,053,000 mules.

1909.-Promising new fruits mentioned and illustrated in the Year Book of the United States Department of Agriculture: Mother apple, Coffman apple, Diploma currant, Carrie gooseberry, Winfield raspberry, Tictor Roselle or "Jamaica Sorrel."

1909.--Union Stoek Yarts at Portland, Oregon. openerl fol businass in the month of September. Stock is raceived both by water and rail.

1909, November 2d.-A ship-load of Australiun meat, sterilized and chilled by the tinley process, arrived in 1.ondon after being serenty days in transit. It was chilled at 30 to "1 degrees instead of the usual rreezing at 10 to 15 degrees. The shipper was Mr. John Cooke, of Melbourne, Australiu.

1909-Grain production of the year: $2,552,190,000$ bushels corn, 653,350,000 bushels wheat and 1,007,129,000 bushels oats, $173,321,000$ bushels barley and $29,520,000$ bushels rye.

1909.-Iighest wheat. June, $\$ 1.60 ;$ highest corn, June, 77 cents; highest oats, May, $601 / 2$ cents. Lowest wheat. August, $99 \mathrm{~s} / 4$ cents; lowest corn, January, 581/4 cents; lowest oats, August, $361 / 2$ eents.

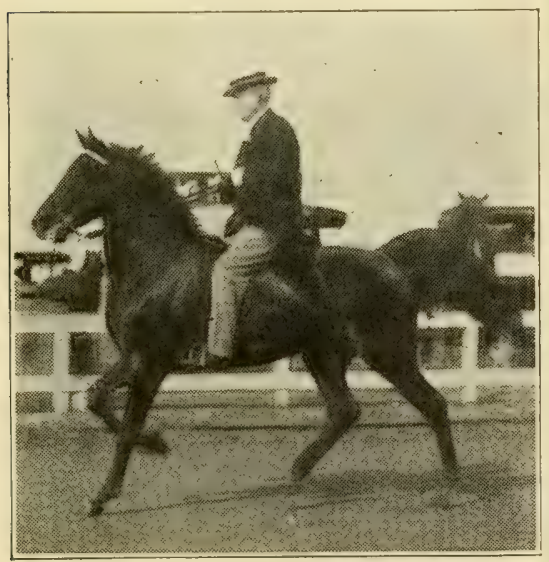

GOLDEN GLCW - CHESTNUT SADDLE MARE. 15.2 han 15 high; daughter of Rex Peavine, a son of Rex McDonald. Sold recently for $\$ 2,100$ at Lexington, $\mathrm{Ky}$., to Mr. Chester W. Chánin, of New York City. The price is said to le the highest ever paid for a saddle mare at auction.

1910, January 1st.-United States Department of Agriculture estimate of number of farm animals: $21,801,000$ milch cows, 47,279,000 other cattle, 47,782,000 hors, 57,216. 000 sheep, $21,040,000$ horses and $4,123,000$ mules.

1910.-Promising new fruits mentioned and illustrated in the Year Book of the United States Department of Agriculture Lowry apple, Kinnard apple, Payne peach. Hoosier raspberry, Dugat orange, Family Avocado, Tamopan persimmon and Cecil Mango.

1910. September 22d.-At the age of $S 5$ David Rankin, of Tarkio, Mo., died, Born, May 28th, 1825, in Sullivan county, Indiana. He lived to be the most notable farmer of his day and the owner of the largest tracts of rich land. He raised a million bushels of corn on 19,000 acres in one year, but above all he was a stockman, marketing hogs and cattle of his own raising and feeding.

1910.-Grain production of the year: 2,886,260,000 bushels corn, $635,121,000$ bushels wheat, $1,186,341,000$ bushels oats, 173 . 832,000 bushels barley, $34,897,000$ bushels rye.

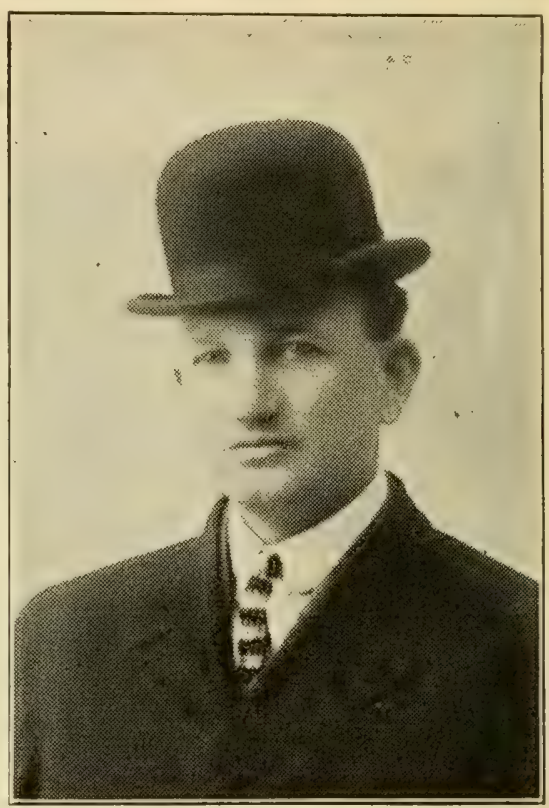

MR. R. A. JAMES, of Charleston, Ill., exhibitor of the best ear of corn of the National Corn Exposition of 1910.

1910.-Iighest wheat, July, $\$ 1.291 / 2$; highest corn, January, $6 \mathrm{~s}$ cents; highest oats, February, 49 cents, Lowest wheat, November, $861 / 2$ cents; lowest corn, December, $44^{1 / 4}$ cents; lowest oats, October, $293 / 4$ cents.

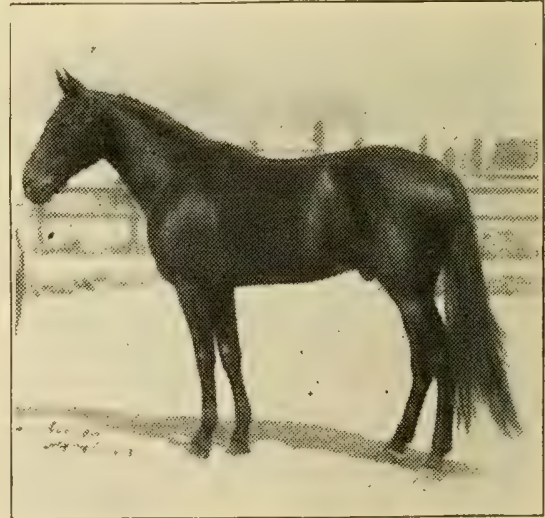

DAN PATCH, 1:55 - Pacing stallion. Champion harness horse of the world. Owned by Mr. M. W. Savage, of Minneapolis, Minn.

Note by the Editor and Compiler.Having collected the material for the History of Acriculture by Dates and placed it in pamphlet form we are convinced that the work is a collection of seraps which will require considerable effort to correct and improve, It is, however, an original work. and by printing the subject of each item in bold-faced type there is practically no need of an index. "The History of Agriculture by Dates is sold at a fair price for what it is, a foundation work, to be published year after year, and be made better every time. 


\section{BOOK DEPARTMENT.}

The following books by the hest anthorilies, all standarl works, are for sale at the price stated and wall he sent by parel post propaid on receipt of

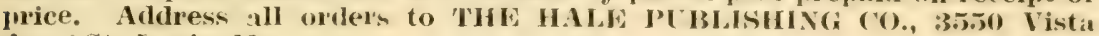
Ave., St. Louis, Mo.

The American Apple Orchard.

By F. A. Waugh. This work is the result of actual experience and observation of a practical man. It is what everyone interested in apples lias been looking for. Of all fruit crops, the apple is not only the most pouular, but it is alco the most profitable, and in this book chief prominence has been given to modern commercial methods as practiced in large and up-to-date orchards. At the same time the family orchard is not neglected, for special treatment of the subject has been given. Methods are discussed, not for their theoretical value, but from the standpoint of cash profits. Anyone interested in apples will find this a valuable and helpful guide. Illustrated. $5 \times 7$ inches. 226 pages. Price, \$1.00. Hale rublishing Co., 3550 Vista Ave., St. Louis, Mo.

\section{American Cactle Doctor.}

By George H. Dadd, V. S. A complete work on all the diseases of cattle, sheep and swine, including every dispase peculiar to America, and embracing all the latest information on the cattle plague and trichina; containing also a guide to symptoms, a table of weights and measures, and a list of valuable medicines. Illustrated. 367 pages. $6 \times 9$ inches. Bound in cloth, by mail, postpaid, $\$ 2.00$. Hale Publishing Co., 3550 Vista Ave., St. Louis, Mo.

\section{American Fruit Culturist.}

By John J. 'Thomas. Containing practical directions for the propagation and culture of all the fruits adapted to the United States. Twentieth thoronghy revised and greatly enlarged edition by $\mathrm{W} m$. $\mathrm{H}$. S. Wood. This new edition makes the work practically almost a new book, containing evervthing pertaining to large and small fruits as well as subtropical and tropical fruits. Richly illustrater by nearly 800 engravings. 758 pages. 12mo. Price, $\$ 2.50$. Hale Publishing Co., 3550 Vista Ave,, St. Louis, Mo.

American Grape Growing and Wine Making.

By George Husmann. New and enlarged edition. Witl contributions from well-known grape growers, giving wide range of experience. The author of this book is a recognized authority on the subject. Illustrated. 269 pages. $5 \times 7$ inches. Cloth. Price. \$1.50. Hale Publishing Co., 35.50 Vista Ave., St. Louis, Mo.

\section{The American Peach Orchard.}

By F. A. Waush. This book is intended to be of service to the beginner as well as the commercial grower of peaches. An idea of the scope and completeness of the book may be had by noting the following subjects, each of which has been treated in a separate chapter: Peach-growing Geography, Climatology, Soils and Exposures, How to Get the Trees, Orchard Planting, General Management, Cover Crops, the Use of Fertilizers, Pruning and Renovation, Insect Enemies, Diseases of Tree and Fruit, Spraying, Marketing the Crop, the Family Orchard, Botanical and Pomologica! Status, Choosing Varieties, Variety Catalogue, the Nectarine, Utilizing the Fruit, Historical Sketch. To anyone who wants to know the latest, on peach culture, this book will be worth many times its cost. Fully illustrated. $5 \times 7$ inches. 275 pages. Cloth. Price, $\$ 1.00$. Hale Puhlishing Co., 3550 Vista Ave., St. Louis, Mo.

\section{Animal lireeding.}

By Thomas Shaw. This is the first book which has systematized the subject of animal breeding. The leading laws which govern this most intricate question the author has boldly defined and authoritatively arranged. The chapters on the more involved features of the subject, as sex and the relative influence of parents, should go far toward setting at rest the widely speculative views cherished with reference to these questions. Illustrated. $40 \mathrm{~J}$ pages, $5 \times 7$ inches. Cloth. Price. $\$ 1.50$. Hale Puilishing Co., 3550 Vista Are., St. Louis, Mo.

Barn Plans and Outbuildings.

This book contains clapters on the economic erection and use of barns; grain barns, horse barns, cattle barns, sheep barns, corn houses, 
smoke houses, ice houses, pig pens, granaries, etc. There are likewise chapters upon bird houses, dog houses, tool sheds, ventilators, roofs and roofing, doors and fastenings, workshops, poultry houses, manure sheds, barnyards, root pits, ete. 23 is pages. $5 \times 7$ inches. Cloth. Price, $\$ 1.00$, Hale Publishing Co., 3550 Vista Ave., St. Louis, Mio.

\section{Clovers, and How to Grow Them.}

By Thomas Shaw. This is the first book published which treats on the growth, cultivation and treatment of clovers as applicable to all parts of the United States and Canada, and which takes up the entire subject in a systematic way and consecutive sequence. The importance of clover in the economy of the farm is so great that an exhaustive work on this subject will, no doubt, be welcomed by students in asriculture as weil as by all who are interested in the tilling of the soil. Illustrated. $5 \times 7$ inches. 337 pages. Cloti. Price, $\$ 1.00$. Hale Publishing Co. 3550 Vista Ave., St. Louis, Mo.

\section{Coburn's Swine Husbandry.}

By F. D. Coburn. New, revised and enlarged edition. The breeding, rearing and management of swine, and the prevention and treatment of their diseases. It is the fullest and freshest compendium relating to swine breeding yet offered. Illustrated. 312 pages. $5 \times 7$ inches. Cloth. Price, \$1.50. Hale Publishing Co., 3550 Vista Ave.,St.Louis,Mo.

\section{Cranberry Culture.}

Hy Joseph J. White. Contents: Natural history, history of cultivation, choice of location, preparing the ground, planting the vines, management of meadows, flording, enemies and difficulties overcome, picking, keeping, profit and loss. Illustrated. 132 pages. Cloth. Price, $\$ 1.00$ Hale Publishing Co., 3550 Vista Ave., St. Louis, Mo.

\section{Dadd's American Reformed Horse Boolk.}

By George H. Dadd, V.S. A treatise on the causes, symptoms and cure of every disease incident to the loorse, including all diseases peculiar to America, and which are not treated of in the works based upon the works of Youatt, Mason and others. Embracing also full details of breeding, rearing and management on the reform system of practice. Illustrated. 442 pages. $6 \times 9$ inches. Cloth. Price, $\$ 1.00$. Hale Publishing Co., 3550 Vista Ave, St.Louis, Mo.

\section{The Dairyman's Manual.}

By Henry Stewart, author of "The Shepherd's Manual," "Irrigation," etc. A useful and practical work by a writer who is well known as thoroughly familiar with the subject of which he writes. 1llustrated. 475 pages. $5 \times 7$ inches. Cloth. Price, $\$ 1.50$. Hale Publishing Co., 3550 Vista Ave, St. Louis, Mo.

\section{Farm Irithmetic.}

By Charles W. Burkett, formerly Professor of Agriculture in the New Hampshire College of Agriculture, and Karl D. Swart sel, Professor of Mathematics, Ohio State University. For the first time in book making a real farm arithrnctic has been thought out, developed and printed. This book applies to the everyday life of the farm boy and girl and is designed for a basic study in every school and in every rural community. It supplies new, accurate, useful and interesting problems for practice. drill and review. It will tend to develop in the mind of the pupil an appreciation of and an insight into the quantitative side of farm life. 280 pages. $5 \times 7$ inches. Cloth. Price, $\$ 1.00$. Hale Publishing Co., 3550 Vista Ave., St. Louis, Mo.

\section{Soil and Crops of the Farm.}

By George E. Morrow, M. A., and Thomas F. Hunt. "The methods of making available the plant food in the soil are described in popular language. A short history of each of the farm crops is accompanied by a discussion of its culture. The useful discoveries of science are explained as applied in the most approved methods of culture. Illustrated. 310 pages. Cloth. Price, \$1.00. Hale Publishing Co., 3550 Vista Ave., St Louis, Mo.

Beginner's Guide to Fruit Growing.

By F. A. Waugh. The great majority of books are written for the professional farmer or fruit grower, for the one who bas spent his life on the soil and who already knows all the simple facts. Yet these simplest things-the most necessary to surcess-are just the thing that the genuine beginner does not know. 'The need of such a beginners' book is, no doubt, more urgent in the field of fruit growing than anywhere else, and the reason that this line of work appeals especially to people removing from the city to country. Illustrated. 5x 7 inclies. 120 pages. Cloth. Price, 75 cents. Hale Publishing Co., 3550 Vista Ave., St. Louis, Mo. 


\section{The rook of Corn.}

By Herbert Myrick, assisted by $A$. D. Shamel, E. A. Burnett, Albert W. Fulton, B. W. Snow and other capable specialists. A complete treatise upon the culture, marketing and uses of maize in America and elsewhere, for farmers, dealers and others. Illustrated. Upwards of 500 pages. ¿x7 inches. Cloth. Price by mail, prepaid, $\$ 1.50$. Itale Publishing Co., 3550 Vista Ave., St. Louis, Mo.

\section{The Jook of IVheat.}

By P. T. Dondlinger. This book comprises a complete stuay of every. thing pertaining to wheat. It is the work of a student of economic as well as agricultural conditions, weli fitted by the broad experience in both practical and theoretical lines to tell the whole story in a condensed form. It is designed for the farmer, the teacher and the student as well, and the bibliography which accont panies the book alone is worth many time its price to the investigator of any subject connected with the culture of wheat. Illustrated. $51 / 2 \times 8$ inches. 370 payes. Cloth. Price, \$2.00. Hale Publishing Co., 3550 Vista Ave., St. Louis, Mo.

\section{The Business of Dairying.}

By C. B. Lane. The author of this practical little book is to be congratulated on the successful manner in which he has treated so important a subject. It has been prepared for the use of dairy students, producers and handlers of milk and all who make dairying a business. Its pulpose is to present in a clear and concise inanner various business methods and systems which will help the dairyman to reap sreater profits. This book meets the needs of the average dairy farmer, and if carefully followed will lead to successful dairying. Illustrated. 5x7 inches. Cloth. Price, \$1.50. Hale Publishing Co., 3550 Vista Ave.,St.Louis, Mo.

\section{Farm Crops.}

By Charles William Burkett. This volume abounds in helpful suggestions and valuable information for the most successful growing of the various larm crops, whether large or small areas are allotled to them, and it is a plain, practical and reliable guide and tells of the best ways of handling crops from the time the land is made rearly until the harvest product is sold. Contents: Good Soils Back of Good Crops, How Rotations Help Out; Crop Yields and Proper Culture; Wheat Crops For Stock Feeding; The Sile, Silage and Soiling
Crop; Every Farmer a Plant Breeder: and Farm Crops. Illustrated, 5x? inches. 288 pages. Cloth. By mail, postpaid, $\$ 1.50$. Hale Publishins Co., 550 Vista Ave., St. Louis, Mo.

\section{Garlening For pleasure.}

I3y Peter Henderson. A guide to the amateur in the fruit, vegetable and flower garden, with full descriptions for the gresnlouse, conservatory and window garden. It meets the wants of all classes in country. city and village, who keep a garden for their own enjoyment rather than for the sale of products. Finely illustrated. 404 pages. $5 \times 7$ inches. Clotl. Price, $\$ 1.50$. Hale Publishing Co., 3550 Vista Ave,,St.Louis, Mo.

\section{The Iamlscape Beautiful.}

By F. A. Waugh. In these seventeen uapters. or essays, as the author calls them, he presents a delightful study of the landscape in a.ll its phases-historjcal, poetic, literary, artistic, practical, landscape gardening, etc. All written in a most. sympathetic and fascinating style. It will make a highly-appropriate gift book. It is printed from large, clear type, on specially made, deckleedged, woven paper, the illustrations on coated paper in soft tones, gilt top, modern art binding. 336 pages. Size, $6 \frac{1}{1} \times 81 / 4$ inches. Price, $\$ 2.00$. Hale Publishing Co., 3550 Vista Ave., St. Louis, Mo.

\section{Iand Draining.}

By Manly Miles. A book for farmers on the principles and practice of draining, siving the results of his extendea experience in laying tile drains. The directions for the laying out and the construction of tile drains will enable the farmer to avoid the errors of imperfect construction and the disappointment that must necessarily follow. Illustrated. 200 pazes. $5 \times 7$ inches. Cloth. Price, \$1.00. Hale Publishing Co., 3550 Vista Ave,,St.Louis,Mo.

Market Gardening and Farm Notes.

By Burnett Landreth. Experiences and observations for both North and South, of interest to the amateur gardener, trucker and farmer. A novel feature is the calendar of farm and garden operations for each month; the chapters on fertilizers, transplanting. succession and rotation of crops, the packing, shipping and marketing of vegetables will be especially useful to market gardeners. Illustrated. 315 pages. $5 \times 7$ inches. Cloth. Price, $\$ 1.00$. Hale Publishing Co., 3550 Vista Ave., St. Louis, Mo. 


\section{Making Poultry Pay.}

By Edwin C. Powell. A manual of practical inforvation on poultry keeping. It tells what to do, why to do it, and how to do it. Illustrated. 324 pages. $5 \times 6 \%$ inclies. Bound in cloth. Price, 1.00 , by mail, postpaid. Hale Publishing Co., 3550 Vista Ave., St. Louis, Mo.

\section{Management and Jreeding of Horses.}

By MI. $\mathbb{T}^{T}$. Harper. In this volume the entire subject of judging, feeding, breeding, care and management as well as the history and description of each of the breeds of horses is presented in a most practical manner. The book is illustrated with many cuts of the best types of horses and the most approvid methods of handling them. $\Delta \mathrm{r}$ attempt has betn made to arrange the subject. so that the book may be used as a text as well as a practical guide for the farmer and horse breeder. Illustrated. $5 \frac{1}{2} \times 8$ incines. 466 pages. Cloth. Price, \$2.10. Hale Publishing Co., 3550 Vista Ave.,St.Louis,Mo.

\section{The Management and Feeding of Cattle.}

By Frof. Thomias Shaw. The place for this book will be at once apparent when it is stated that it is the first book that has ever been written which discusses the management and feeding of cattle, from the birth of the calf until it has fulfilled its mission in life, whether on the blnck or at the pail. The book is handsomely printed on fine paper, from large, clear type. Fully illustrated. $51 / 2 \times 8$ inches. 496 pages. Bound in cloth, by mail, postpaid, $\$ 2.00$. Hale Publishing Co., 355:) Vista Ave., St. Louis, Mo.

\section{Molern fouse Plans For Everybody.}

By S. B. Reed. This useful volume meets the wants of persons of moderate means, and gives a wide range of designs, from a dwelling costing $\$ 250$ up to $\$ 8,000$, and adapted to farm, village or town residences. Nearly all of these plans have been tested by practical working. Profusely illustrated. 243 pages. $5 \times 7$ inclies. Cloth. Price, $\$ 1.00$. Hale Publishing Co., 3:50 Vista Ave., St. Louis, Mo.

\section{The New Ega Farm.}

By H. H. Stoddard. A practical, reliable manual upon' producing eggs and poultry for market as a profitable business enterprise, either by itself or connected with other branches of agriculture. It tells all about how to teed and manage; how to breed and select incubators and brooders; its lator-saving devices, etc. 140 original illustrations. 331 pages. $5 \times 7$ inches. Cloth. Price, \$1.00. Hale Publishing Co., 3550 Vista Ave., St. Louis, Mo.

\section{The Nut Culturist.}

By Andrew S. Fuller. A treatise on the propagation, planting and cultivation of nut-bearing trees and shrubs adapted to the climate of the United States, with the scientific and common names of the fruits known in commerce as edible or otherwise useful nuts. Illustrated. 290 pages. $5 \times 7$ inches. Cloth. Price, $\$ 1.50$. Hale Publishing Co., 3550 Vista Ave., St. Louis, Mo.

\section{Peach Culture.}

Ey Hon. J. Alexander Fulton. The best work on peach growing. It has been thoroughly revised and a large portion of it rewritten, bringing it down to date. Illustrated. 204 pages. $5 \times 7$ inches. Cloth. Price, $\$ 1 . ; 0$. Hale Publishing Co., 3550 Vista Ave., St. Louis, Mo.

\section{Quimby's New Beekeeping.}

By L. C. Root. The mysteries of beekeeping explanned. Combinino result of fifty-years' experience with the latest discoveries and inventions and presenting the most approved methods, forming a complete work. Illustrated. 271 pages. $5 \times 7$ inches. Cloth. Price, postpaid, $\$ 1.00$. Hale Publishing Co., 3550 Vista Ave., St. Louis, Mo.

Insects and Insecticides.

A book by Clarence M. Weed.D.Sc, Professor of Entomology and Zoology, New Hampshire College of Agriculture. A practical manual concerning noxious insects and methods of preventing their injuries. 334 pages, with many illustraticns. $5 \times 7$ inches. Cloth. Price, $\$ 1.50$. Hale Publishing Co, 3550 Vista Ave.,St.Louis, Mo.

\section{Fumigation Methods.}

By Willis G. Johnson. A timely, up-to-date book on the practical application of the new methods for destroying insects with hydrocyanic acid gas and carbon hisulphide, the most powerful insecticides ever discovered. It is an indispensable book for farmers, fruit glowers, nurserymen, gardeners, florists, millers, grain dealers, transportation companies. college and Experiment Station workers, etc. Illustrated. 313 pages. $5 \times 7$ inches. Cloth-bound. Price, \$1.00. Hale Publishing Co., 3550 Vista Ave., St. Jouis, Mo. 


\section{Grape Culturist.}

By A. S. Fuller. This is one of the very best of works upon the culture of the liardy grapes, with full directions for all departments of propagation, culture, etc. With 150 excellent engravings, illustrating planting, training, grafting, etc. 292 pages. $5 x$ ? inches. Cloth. Price, \$1.50. Hale Publishing Co., 3550 Vista Ave, St. Louis, Mo.

\section{Greenhouse Construction.}

By L. R. Taft. A complete treatise on greenhouse strictures and arrangements of the various forms and styies of plant houses, for professional florists as well as amateurs. All the best and most improved structures are clearly described. The modern and most successful methous of heating and ventilating are fully treated upon. Special chapters are devoted to houses used for the growing of one kind of plants exclusively. The construction of hotbeds and frames receives appropriate attention. Over 210 vages. $5 \times 7$ inches. Nicely bound in cloth. Price, $\$ 1.50$. Hale Publishing Co., 3550 Vista Ave., St. Louis, MIo.

\section{Greenhouse Manggement.}

By L. R. Taft. This book forms an almost indispensable companion volume to "Greenhouse Construction." So minute and practical are the various systems and methods of growing and forcing roses, violets, carnations and all the most important florists' plants, as well as fruits and vegetables, described, that by a careful study of this work and the following of its teachings, failure is almost impossible. Illustrated. 328 pages. $5 \times 7$ inches. Nicely bound in cloth. Price, $\$ 1.50$. Hale Publishing Co., 3550 Vista Ave.,St.Louis,Mo.

\section{Guenon's Treatise on Milch Cows.}

By Thomas J. Hand, Secretary of the American Jersey Cattle Club. A treatise on the bovine species in general. An entirely new translation of the last edition of this popular and instructive book. With over 100 illustrations, especially engraved for this work. 131 pages. $5 \times 7$ inches. Cloth. Price, $\$ 1.00$. Hale Publishing Co., 3550 Vista Ave.,St.Louis,Mo.

\section{Handy Farm Devices and How to} Make Them.

By R. Cobleigh. This book contains directions for making things for almost every conceivable farm purpose, including appliances for the care of horses, cattle, sheep, hogs, poultry and bees; gates, fences, ap- pliances for the garden, orchard, woods, house, barns and outbuildings. In every instance there is a clear, complete description with illustrations. 5x7 inches. 288 pages. Cloth. I'rice, \$1,io. Hale Publishing Co., 3550 Vista Ave.,St.Louis, Mo.

\section{Harris on the l'ig.}

By Joseph Harris. The points of the various English and American breeds are thoroughly discussed, and the great advantage of using thoroughbred males clearly shown. The work is equally valuable to the farmer who keeps but few pigs and to the breeder on an extensive scale. Illustrated. 318 pages. $5 \times 7$ inches. Cloth. Price, \$1.00. Hale Publishing Co., 3550 Vista Ave.,St.Louis, Mo.

\section{Herbert's IInts to Ilorse Keepers.}

By the late Henry William Herbert (Frank Forroster). This is one of the best and most popular works on the horse orepared in this country. A complete manual for horsemen, embracing: How to breed a horse; how to buy a horse; how to break a horse; how to use a horse; how to feed a horse: how to physic a horse (allopathy or homoeopathy); how to groom a horse; how to drive a horse; how to ride a horse, ete. Beautifully illustrated. 425 pages. $5 \times 7$ inches. Cloth. Price, $\$ 1.50$. Hale Publishing Co., 3550 Vista Ave. St. Louis, Mo.

\section{Homes For Home Builders.}

Edited and arranged by W. D. King, architect, of New York. Farm and village house plans, also plans of barns, stables, poultry houses, etc., in great variety. 251 pages. $5 \times 7$ inches. Bound in eloth. Price, $\$ 1.00$. Hale Publishing Co., 3550 Vista Ave., St. Louis, Mo.

\section{Soiling Crons and the Silo.}

By Thomas Shaw, Professor of Anjinal Husbandry at the University of Minnesota. How to cultivate anil harvest crolos; how to build and fill a silo; how to use silage. The newest and most valuable of all bocks for the dairyman. It tells all about growing and feeding all kinds of soiling crops that have been found useful in any part of the United States or Canada-climate and soil to which they are adapted, rotation, sowing, cultivating and feeding. Also about building and filling silos, what to use and how to fill and feed it. Illustrated. 364 pages. $5 \times 7$ inches. Cloth. Price, $\$ 1.50$. Hale Publishing Co., 3550 Vista Ave., St. Louis, Mo. 


\section{Farm Development.}

By Willet M. Hays. It takes up farming as a vocation, tells about the geological history of the earth, explains the way soil is made, describes the manner of selecting a farm home, how to subdue the land, how to drain and irrigate, and how to build roads, bridges and fences. The author is one of our leading agricultural educators and lias been a foremost worker in introducing agriculture in the common schools. Profusely illustrated. $51 / 2 \times 8$ inches. :32 pages Cloth. By mail, postpaid, $\$ 1.50$. Hale Publishing Co., 3550 Vista Ave., St. Louis, Mo.

\section{Farm Machinery and Farm Motors.}

By J. B. Davidson and L. W. Chase. Farm Machinery and Farm Motors is the tirst American book published on the subject of Farm Machinery since that written by J. J. Thomas in 1867. This was before the development of many of the more important iarm luachines and the general application of power to the work of the farm. Modern farm machinery is indispensable in present-day farming operations. and a practical book like Farm Machinery and Farm Motors will fill a much-felt need. Although written primarily as a text-book, it is equally useful for the practical farmer. Profusely illustrated. $51 / 2 \times 8$ inches. 520 pages. Handsomely bound in cloth. Price, $\$ 2.00$. Hale Publishing Co., 3550 Vista Ave., St. Louis, Mo.

\section{Tho Saddle Horse.}

A complete guide for rioling and training. This is a complete and reliable guide book for all who desire to acquire the accomplisinment of horsemanship and who wish to teach their animals low to perform various feats under the saddle. Illustrated. 5x7 inclies. Cloth. Price, $\$ 1.00$. Hale Publishing Co., 3550 Vista Ave., St. Iouis, Mo.

\section{Farm Manures.}

By Chas. E. 'Thorne. This is the most complete and exhaustive work of the kind ever published on the production and handling of animal manures. 1t tells in concise form the essential things that every farmer and tiller of the soil should know. A plain, practical account of the effects of various kinds of manures on the soil and the composition of farm crops and of the effect of different fertilizing elements on their growth. The book will not only interest practical farmers, but intending farmers who feel the call to go on the land and grow crops. lllustrated. $5 \times 7$ inches. 300 pages. Price. \$1.50. Hale Publishing Co., 3550 Vista Ave., St. Louis, Mo.

\section{Talks on Manures.}

By Joseph Haris, M. S. A series of familiar and practical talks between the author and the deacon, the doctor and other neighbors, on the whcle subject of manures and fertil-izers, including a chapter especially written for it by Sir John Bennet Lawes, of Rothamsted. England. $366^{\circ}$ pages, $5 \times 7$ inches. Cloth-bound. Price, by mail, postpaid, $\$ 1.50$. Hale Publishing Co., 3550 Vista Ave., St. L.ollis, Mo.

\section{l'urkeys, and How to Grow Them.}

Edited by Herbert Myrick. A treatise on the natural history of turkeys; the various breeds and the best methods to insure success in the business of turkey growing. Illustrated. 151 pages. $5 \times 7$ inches. Cloth. Price, $\$ 1.00$. Hale Publishing Co., 3550 Vista Ave.,St.Louis, Mo.

\section{Gardening For Profit.}

By Peter Henderson. The standard work on market and family gardening. The successful experience of the author for more than thirty years, and his willingness to tell, as he does in this work, the secret of his success for the benefit of others, enables him to give most valuable information. The took is profusely illustrated. 376 pages. $5 \times 7$ inches. Cloth. Price, $\$ 1.50$. Hale Publishing Co., 3550 Vista Are., St. Louis, Mo.

\section{Farm stock.}

By. C. W. Burkett. There are few men in the country better qualified to write on this subject than Professor Burkett, late. Director of tlie Kansas Experiment Station, and now editor of the American Agriculturist. The writer handles, in a brief, yet practical and thorough manner, the breeding and feecing, care and management, of all classes of farm stock. The chapters on beef, mutton and pork making show how the small breeder can make money. For the average farmer there is no book on farm stock just like it. Written in a simple, straightforward way, with all technical terms and expressions fully explained, it is designed for the average farmer, yet the largest breeder can profit by using it as a guide. Fully illustrated. $5 \times 71 / \mathrm{g}$ inches. 350 pages. Found in cloth. by mail, postpaid, $\$ 1.50$. Hale Publishing Co., 3550 T'ista Ave., St. Louis, Mo. 


\section{The For:age ant Fiber Crops in America.}

By 'Thomas H'. Hunt. This book is exactly what its title indicates. It is indispensable to the farmer, student and teacher who wishes all the latest and most important information on the subject of forage and fiber crops. Like its famous companion, "l'he Cereals in Anierica." by the same author, it ireats of the cultivation and improvement of every one of the forage and fiber crops. With this book in hand you have the latest and most up-to-date information available. Illustrated. 428 pages. $51 / 2 \times 8$ inches. Bound in cloth. Price, postpaid, \$1.75. Hale Publishing Co., 3550 Vista Ave., St. I.ouis, Mo.

\section{Forage Crops Other Than Grasses.}

How to Cultivete and Use Them. By Thomas Shav. Scon forage crops other than grasses will be growi from sea to sea. 'This new departure may revolutionise the stock and dairy business of Imerica. Professor Shaw's booli telis all about it-just what has been done, how it was done and how any and every farmer can do likewise. Scientifically accurate, the book is intensely practical. 1llustrated. 287 pages. $5 \times 7$ inches. By mail, nostpaid, $\$ 1.00$ Hale Publishing Co., St. Louis, Mo.

\section{Forest Planting.}

I3y H. Nicholas Jarchow, LL.D. A treatise on the care of woodlands and the restoration of the denuded timber lands on plains and mountains, full instructions being given for forest planting of our various kinds of soil and subsoil. Illustrated. 250 pages, $5 \times 7$ inches. Cloth-bound. Price, $\$ 1.50$. Hale Publishing Co. $35: 0$ Vista Ave., St. Louis, Mo.

The Horse; How to Buy and Sell.

By Peter Howden. Giving the noints which distinguish a sound from an unsolud lorse. This volume abounds in general informa. tion, stated in so clear and simple a manner as to enable anyone to intelligently buy and sell a horse. 13! pages. $5 \times 7$ inches. Cloth. Price. $\$ 1.00$. Hale Publishing Co., 3550 Vista Ave., St. Louis, Mo.

\section{How Crops Feed.}

By Prof. Saniuel W. Johnson. A treatise on the atmosphere and the soil, as related in the nutrition of agricultural plants. The volumethe companion and complement to "How Crops Grow"-has been welconjed by those who appreciate the scientific aspect of agriculture. Illustrated. 376 pages. $5 \times 7$ inches.
Cloth. By mail, postpaid. Price, $\$ 1.50$. Hale Publishing Co., 3550 Vista Ave., St. Louis, I.Io.

\section{How Crons Grow.}

By Prof. Samuel W. Jolinson. A treatise on the chemical composition, structure and life of the plant. A guide to the knovledse of agricultural plants, their composition, their structure and models of development and growth; of the complex organization of plants, and the use of the parts; the germinotion of seeds, anul the food oi plants obtained both from the air and the soil. Illustrated. 416 payes. $5 \times 7$ inches. Cloth-bound, by mail, postpaid, $\$ 1.50$. Hale Publishing Co., 3550 Vista Ave., St. Jouis, Mo.

\section{The Ice Crop.}

$\Lambda$ book by Theron $L$. Hiles. How to harvest, ship and use ice. A complete, practical treatise for farmers, dairymen, ice dealers, produce shippers, meat packers, cold storers, and all interested in ice houses, cold storage and the handling or use of ice in any way. Including many recipes for iced dishes and beverages. The book is illustrated by cuts of the tools and machinery used in cutting and storing ice, and the different forms of ice houses and cold storage buildings. Illustrated. 122 pages. $5 \times 7$ inches. Cloth. Price, $\$ 1.00$. Hale Publishing Co., 3550 Vista Ave., St. Louis, Mo.

\section{Insects Injurious to Vegetables.}

A book by F. H. Chittenden, S.C.D. A complete, prartical work, giving descriptions of the most important insects attacking vegetables of all kinds, with simple and inexpensive remedies to check and destroy them, together with timely suggestions to prevent their recurence. Profusely illustrated. $51 / 2 \times 8$ inches. 300 pages. Cloth. By mail, postpaid, $\$ 1.50$. Hale Publishing Co., 3550 Vista Ave. St. Louis, Mo.

Fruit Harvesting, Storing, Marketing.

Fy F. A. Waugh. A practical guide to the picking, storing, shipping and marketing of fruit. The principal subjects covered are the fruit market, fruit picking, sorting and packing, fruit storage, evaporating, canning, statistics of the fruit:trade, fruit package laws, commission dealers and dealing, cold storage, etc. No progressive fruit grower can afford to be without this most valuable book. Illustrated. 232 pages. $5 \times 7$ inches. Cloth. Price, $\$ 1.00$. Hale Publishing Co., 3550 Vista Ave., St. Louis, Mo. 


\section{Swine in America.}

By F. D. Coburn. This great book on hog raising is a guide to every grower and a text-book to every student. What he had already done for alfalfa, Mr. Coburn now has done for swine. This great industry is treated in his new work, "Swine in America," in a most exhaustive manner. Every phase of hog raising is considered from a practical standpoint, and the latest contributions to the science and art of handling and managing hogs weiglied and discussed in this important work down to the hour of publication. If you have anything at all to do with hogs, get this book. This book contains 650 pages, $6 \times 9$ inches, bound in fine silk cloth, gold stamping, making it one of the handsomest and most attractive agricultural books now before the public. Price, $\$ 2.50$. Hale Publishing Co., 3550 Vista Ave., St. Louis, Mo.

First Principles of Feeding Farm Aninuals.

By C. W. Burkett. As indicated in its title, the book discusses the fundamental and first principles of feeding the animals of the farm. It is of simple construction, takes up the subject step jy step, making it possible for the practical man or student to understand clearly and fully both the science and the practice of this important subject. Illustrated. $34 \mathrm{~s}$ pages. $5 \times 7$ inches. Cloth. Price, $\$ 1.50$. Hale Publishing Co., 3550 Vista Ave., St. Louis, Mo

\section{Vegetable Gardening.}

By R. L. Watts. This complete, concise and authentic book covers every phase of vegetable gardening and is especially well organized as a text-book and equally valuable as a handbook for practical growers. It treats fully the questions regarding soils, fertilizers, manures, irrigation, insect enemies and fungous diseases, construction of hot-houses, coldframes, seed growing, vegetables under glass, marketing, etc. Illustrated $51 / \mathrm{s} \times 8$ inches. 525 pages. Cloth. Price, \$1.75. Hale Publishing Co.. 3550 Vista Ave.,St.Louis,Mo.

\section{The F'armer's Veterinarian.}

By Charles William Burkett. This book abounis in helpful suggestions and valuable information for the most successful treatment of ills and accidents, and disease troubles. $\Lambda$ prastical treatise on the diseases of farmi stock, containing brief and popular advice on the nature, cause and treatment of disease, the common ailments and the oare and managemenc of stock when sick. It is profusely illustrated, containing a number of half-tone insert illustrations and a great many drawings picturing diseases, their symptoms and familiar attitudes assumed by farm animals when affected with disease, and presents, for the first time, a plain, practical and satisfactory guide for farmers who are interested in the common discases of the farm. rllustrated. $5 \times 7$ inches. 288 pages. Bound in cloth, by mail, postpaid, $\$ 1.50$. Hale Publishing Co., 3550 Vista Ave., St. Louis, MIo.

\section{Plums and Plum Culture.}

By Prof. F. A. Waugh. A complete manual on all known varieties of plums and their successful management. Plum culture is one of the most complicated of fruit specialties, and Professor Waugh is one of the best known of the specialists, and this work represents in an unusual degree the original discoveries of the author. Nevertheless, the discoveries and practical experience of others have not been disregarded. The book will be found indispensable to the scientist, to the nurseryman and to the cultivator. Illustrated. 391 pages. $5 \times 7$ jnches. Cloth. Price, \$1.50. Hale Publishing Co., 3550 Vista Ave., St. Louis, Mo.

\section{The Study of Breeds.}

By Thomas Shaw. Origin, history, distribution, characteristics, adaptability, uses and standards of excellence of all pedigreed breeds af cattle. sheep and swine in America. The accepted text-book in colleges. and the authority for farmers and breeders. 1llustrated. 371 pages. ix 7 inches. Cloth. Price, $\$ 1.50$. Hale Publishing Co., 3550 Vista Ave., St. Louis, Mo.

\section{The Potato.}

By Samuel Fraser. While the practical side of potato culture has been emphasized, the scientific part has not been neglected, and the information given is of value, both to the grower and the student. It is the most complete, reliable and authoritative book on the potato ever published in America. Illustrated. 200 pages. $5 \times 7$ inches. Cloth-bound, postpaid, 75 cents. Hale Publishing Co., 3550 Vista Ave., St. Louis, Mo.

\section{The Soil of the Farm.}

By John Scott and J. C. Morton. $\Lambda$ handbook of the processes included in the management and cultivating of the soil. 107 pages. $5 \times 7$ inches. Cloth. Price, $\$ 1.00$. Hale Publishing Co., 3550 Vista Ave., St.Louis,Mo. 
The Cereals in America.

By Thomas Fi, Hint, M. S., D. Asri., Professor of $\Lambda$ sronomy, Cornell Liniversity. If you raise five acres of any kind of grain you cannot afford to be without this book. it is in every way the best book on the subject that has ever been written. It treats of the cultivation and improvement of every grain crop raised in America in a thoroughly practical and accurate manner. 'T'he subject matter includes a comprehensive and succinct treatise of wheat, maize, oats, barley, rye, rice, sorglum (Kaftir corn) and buckwlieat, as related particularly to American conditions. Illustrated. 450 pages. $51 / 2 \times 8$ inches. Cloth. Price, $\$ 1.75$ by mail, postpaid. Hale Publishing Co., 35,50 Vista Ave., St. Louis, Mo.

\section{Practical Fioriculture.}

By Peter Henderson. A guide to the successful propagation and cultivation of florists' plants. The work is not for florists and gardeners only, but the amateur's wants are constantly kept in mind. It also comprises a very complete treatise on the cultivation of flowers under glass, or in the open air, suited to those who grow flowers for pleasure as well as those who make them a matter of trade. Jllustrated. 325 pages. $5 \times 7$ inches. Cloth. Price, $\$ 1.50$. Hale Publishing Co., 3550 Vista Ave, St. Louis, Mo.

\section{Profitable Poultry Production.}

By M. G. Kains. 'This book shows how poultry can be made more profitable. From cover to cover the book is written with the one aim of aiding the poultry raiser to make the most money from the farm flocks: hence special emplasis is laid on marketing both poultry and eggs as well as on breeding and feeding. lllustrated. $5 \times 7$ inches. 288 pages. Cloth. Price, $\$ 1.50$. Hale Publishing Co., 8550 Tista Ave.,St.Louis, Mo.

\section{Weeds of the Narm and farden.}

By L. H. Pammel. The enormous Josses amounting to several hundred million dollars annually in the United States calsed by weeds stimulate us to adopt a better system of agriculture. The veed question is, therefore, a most important and vital one for American farmers. This treatise will enable the farmer to treat his field to remove weeds. The bock is profusely illustrated by photograplis and draings made ex. pressly for this work and will prove invaluable to every farmer, land owner, gardener and park superin- tendent. $5 \times 7$ inches. 300 pages. Cloth. Price, by mail, postpaid, $\$ 1.50$. HaJe Publishing Co., 3̆50 Vista Ave., St. Jouis, Mo.

\section{Profitable Slock Iaising.}

By Clarence A. Sllamel. T'his book covers fully tine principles ol breeding and feeding for both fat stock and dairying type. It tells oi sleep and mutton raising, hot-house lambs, the swine industry and the horse market. Finally he tells ot the preparation of stock for the market and how to prepare it so that it will bring a ligh market price. Illustrated. 5x7 inches. 288 pages. Cloth. Price, $\$ 1.50$. Hale Publishing Co., 3550 Vista Ave., St. Louis, Mo.

\section{The Book of Alfalfa.}

History, Cultivation and Merits. Its Uses as a Folage and Fertilizer. The appearance of the Hon. F. D. Coburn's little book on Alfalfa a few years ago has been a profit revelation to thousands of farmers through out the country, and the increasing demand for still more information on the subject has induced the author to prepare the present volume, which is, by far, the most authoritative, complete and valuable work on this forage crop published anywhere. Illustrated. 336 pares. $61 / 2 \times 9$ inches. Cloth. Price by mail, postpaid, $\$ 2.00$. Hale Publishing Co., 3550 Ave., St. Louis, Mo.

\section{Foundations of American Grape Cul- ture.}

By T. V. Munson. This book is original, clear and nractical, besides being the most accurately scientific, clear and practical rork upon American grapes, suited to all sections of the country. It will be a fine money maker to every practical vineyardist who reads it, and a delight and helpmate to every home that grows a few vines about the house, on the trees, on walls or arbors, or garden trellis. Illustrated. $\quad 7 \frac{1}{2} \times 10$ inches. 250 pages. Cloth. Price, $\$ 2.00$. Hale Publishing Co., 3550 Vista Ave., St. Louis, Mo.

\section{Play and Profit in My Garden.}

By E. P. Roe. The author takes us to his garden on the rocky hillside, and shows us how out of it, after four-years' experience, he evoked a profit of $\$ 1,000$, and this while carrying on pastoral and literary labor. Illustrated. 350 pages. $5 \times 7$ inches. Cloth. Price, $\$ 1.50$. Hale Publishing Co., 3550 Vista Ave., St. Louis, Mo. 


\section{The Fruit Garden.}

By P. Barry. A standard work on fruit and fruit trees, the author having had over thirty-years' practical experience at the head of one 0 : the largest nurseries in this country. Invaluable to all fruit growers. Illustrated. 516 pages. $5 \times 7$ inches. Cloth. Price, $\$ 1.50$. Hale Publishing Co., 3550 Vista Ave.,St.Louis, Mo.

\section{Profits in Poultry.}

Useful and ornamental breeds and their profitable management. This excellent work contains the combined experience of a number of practical men in all departments of poultry raising. It is profusely illustrated and forms a unicut and important addition to our poultry literature. 352 pages. $5 \times 7$ inches. Bound in cloth. Price, $\$ 1.00$. Hale Publishing Co., 3550 Vista Ave.,St.Louis,Mo.

The Science and Practice of Cheesemaking.

By I. L. Van Slyke and C. A. Publow. A treatise on the manufacture of American cheddar cheese and some other varieties; intended as a text-book for the use of dairy teachers and students in class-room and work-room; prepared also as a handbook and work for reference for the daily use of practical cheesemakers and cheese-factory operations. This is a work which represents both the scientific and practical sides of cheesemaking and which, in respect to authorship, has been prepared under unusually favorable auspices. Illustrated. $5 \times 7$ inches. Cloth. Price, $\$ 1.50$. Hale Publishing Co., 3550 Vista Ave., St. Louis, Mo.

\section{Systematic Pomology.}

By F. A. Waugh, Professor of Horticulture and Landscape Gardening in the Massachusetts Agricultural College, formerly of the University of Vermont. This is the first book in the English language which has ever marle the attempt at a complete and comprehensive treatment of systematic pomology. It presents clearly and in detail the whole method by which fruits are studied. The book is suitably illustrated. $28 \mathrm{~s}$ pages. $5 \times 7$ inches. Cloth. Price, $\$ 1.00$. Hale Publishing Co., 3550 Vista Ave., St. Louis, Mo.

\section{Fam Drainage.}

By Judge French, of New Hampshire. The principles, process and efforts of draining land with stones, wood, ditch-plows, open ditches, and especially with tiles; including tables of rainfall, evaporation, filtra- tiou, excavation, capacity of pipes, cost and number to the acre. 384 pages. $5 \mathrm{x}^{*}$ inclies. Cloth, $\$ 1.00$. Hale Publishing Co., 3550 Vista Ave., St. Jouis, Mo.

\section{Maling Horticulture Pay.}

By M. G. Kains. This book contains a simple, concise but adequate discussion of soils and their care, fertilizers and fertilizing, water and its control, and the function of cultivation. Then follows a discussion of fruit plantations and their care. the various orchard fruits of temperate North America, and the small fruits of this region. 'The vegetable garden is treated generally, and then the various vegetables ure taken up individually. After a general chapter on spraying, the volume closes with a chapter on ornamentals for the home grounds, gardens, the house and the greenhoise. Illustrated. $5 \times 7$ inches. 288 pages. Cloth. Price, $\$ 1.50$. Hale Publishing Co., 355 f Vista Ave, St. Louis, Mo.

\section{Small Fruit Culturist.}

By Andrew S. Fuller. The book covers the whole ground of propagating small fruits, their culture. varieties, packing for market, etc. it is very finely and thoroughly illustrated, and makes an admirable companion to "The Grape Culturist." 298 pages. $5 \times 7$ inches. Cloth. Price, $\$ 1.00$. Hale Publishing Co., 3550 Vista Ave., St. Louis, Mo.

\section{Pene Culture For I'rofit.}

By P. T. Quinn, Practical Horticulturist. Teaching how to raise pears intelligently, and with the best results, how to find out the character of the soil, the best methods of preparing it, the best varieties to select under existing conditions, the best modes of planting, pruning, fertilizing, grafting and utilizing the ground before the trees come into bearing, and, finally, of gathering and packing for market. Illustrated. 136 pages. $5 \times 7$ inches. Cloth. Price, \$1.00. Hale Putlishing Co., 3550 Vista Ave., St. Louis, Mo.

\section{Cider Makey's Handhook.}

By I. M. Trowbridge. Contents: The properties of cider apple juice; apples, varieties alid tests; apparatus for making cider; pasteurization; old method of cider making. It is a complete guide for the cider maker on a large or small scale. Illustrated. 119 pages. $5 \times 7$ inches. Bound in eloth. Sent prepaid for $\$ 1.00$. Hale Publishing Co., 3550 Ave., St. Louis, Mo. 


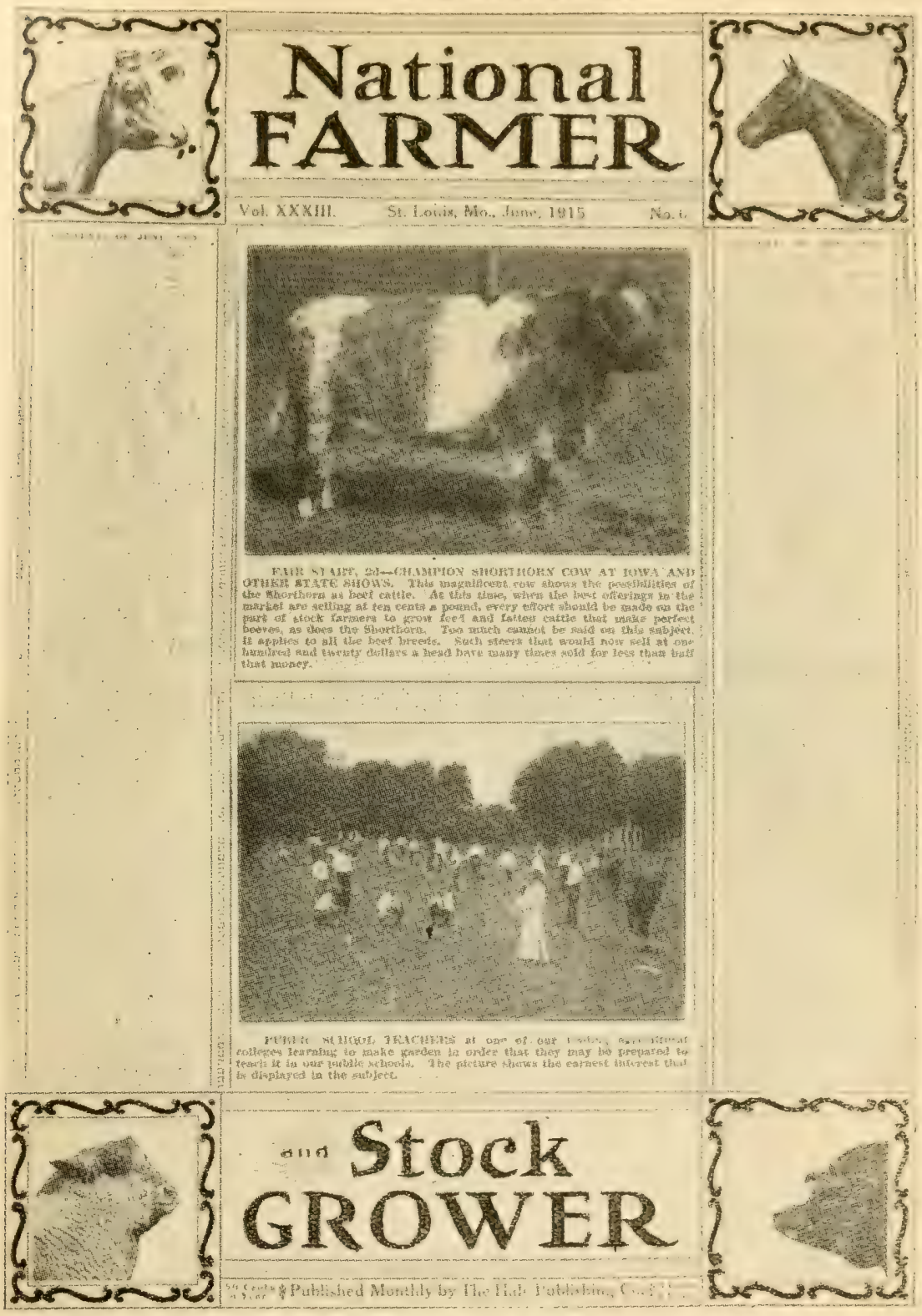

\section{THE NATIONAL FARMER AND STOCK GROWER}

TS a nice, clean, general farm publication, full of practical, interesting and 1 instructive information. It contains good reading for all the family. It is very useful to general farmers, to vegetable and fruit growers, and especially so to cattle, hog and sheep raisers and feeders, to horse and mule raisers and dealers, and it contains more good poultry facts than most of the poultry papers. The best live stock illustrations appear in THE NATIONAL FARMER ANI) STOCK GROWER. There are thirty-two pages, four columns to the page. It is published monthly.

Send us Fifty Cents and we will send you TIIE NATIONAL FARMEI? AND STOCK GROWER for one year, and we will also send you a copy of HALE'S HISTORY OF AGRICULTURE BY DATES.

THE HALE PUBLISHING CO., 3550 Vista Ave., ST. LOUIS, MO. 



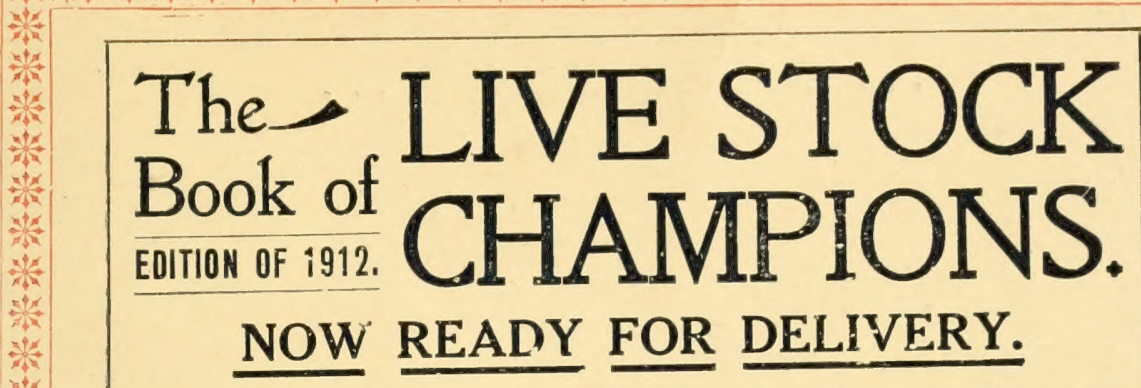

True to Life Pictures Reproduced From Photographs Taken in the Principal Show Rings of the American Continent by the Greatest Animal Artists.

\section{One Thousand Champions,}

Winners in Annual Live Stock Contests at State and National Fairs and Expositions.

THIS is a new edition of the most valuable book ever published 1 in the interest of high-class stock raising. The pictures in THE There are sweepstakes and championship winners at State, National and International Fairs and Expositions. These include individual awards in breeders' competitions, also herds with prize-ring honors; the beef cattle include grand champion steers and car-loads; the dairy cattle include record makers and large producers of milk and butter; the horses include thoroughbred, trotting, coach, draft. hunters, ponies, jack stock, etc. Hogs, sheep and goats are represented by the best in every breed. The book is elegantly bound in blue cloth, 352 pages, with nearly 750 separate and distinct illustrations, one, two, five or more champions to the page.

There is not a second-class animal or inferior picture in the book. Every animal is a record-maker, record-breaker, famous sire, mother of champions, or winner in the prize ring.

\section{Issued as a Souvenir Supplement.}

THE BOOK OF LIVE STOCK CHAMPIONS is published as a Souvenir Supplement to THE NATIONAL FARMER AND STOCK GROWER, issued monthly at St. Louis, Mo., a splendid, clean, general farm publication, full of practical, interesting and instructive information. It contains good reading for all the family. It is very useful to general farmers, vegetable and fruit growers, and especially so to cattle, hog and sheep raisers and feeders, horse and mule raisers and dealers, and it contains more good poultry facts than most of the poultry papers. There are thirty-two pages, four columns to the page.

\section{Special Inducements. AN EXTRAORDINARY OFFER.}

We offer the first ten thousand copies of this edition at One Dollar per copy, including a two-year subscription to THE NATIONAL FARMER AND STOCK GROWER. The first ten thousand copies are handsomely printed on coated paper and elegantly bound in blue cloth, with gilt title. No finer volume was ever offered. Send One Dollar with your order to

The hale PUblishing CO., 3550 Vista Ave., St. Louis, Mo. 

$\ldots$ G R E A T E S T .

\section{Subscription Proposition.}

Co-operative Clubbing Arrangement.

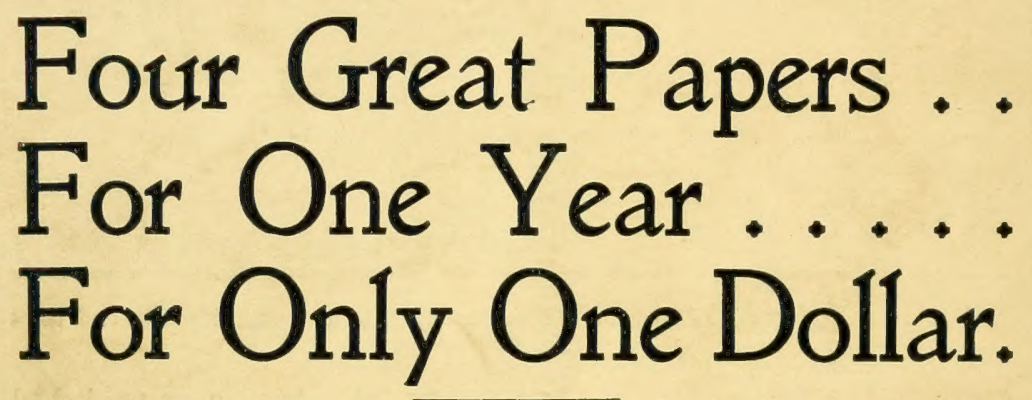

FOUR STERLING, UP-TO-DATE SPECIAL FARM PAPERS.

THE NATIONAL FARMER AND STOCK GROWER -issued monthly-a magnificent guide and counfruit growing, dairying, ftock raising and feeding, markets, etc.
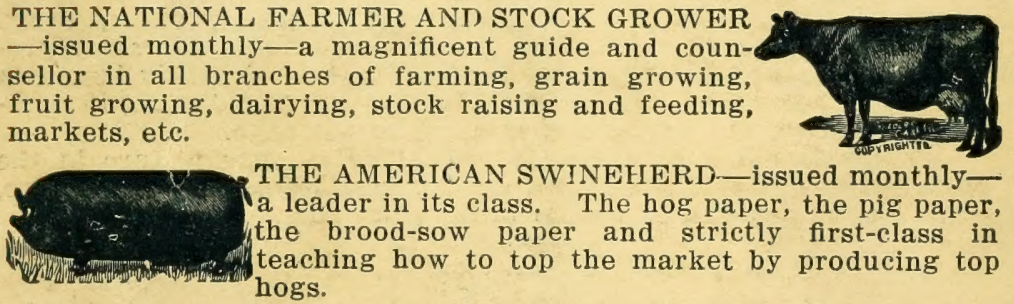

THE SHEPHERDS' JOURNAL is devoted to sheep husbandry on the farm and on the range. It is equally valuable for the breeder as for the, herdsman. It is issued monthly, printed on elegant paper, splendidly illustrated and edited( by practical men.
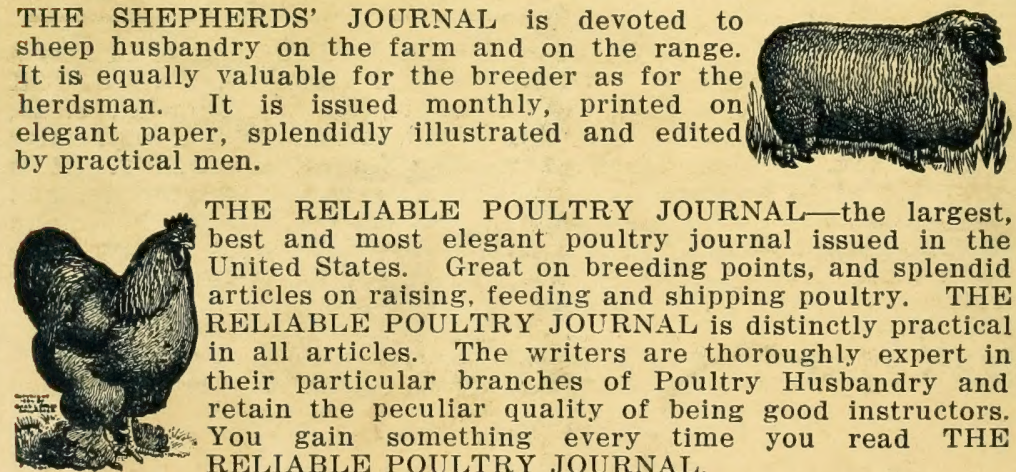

THE RELIABLE POULTRY JOURNAL - the largest, best and most elegant poultry journal issued in the United States. Great on breeding points, and splendid articles on raising, feeding and shipping poultry. THE RELIABLE POULTRY JOURNAL is distinctly practical in all articles. The writers are thoroughly expert in their particular branches of Poultry Husbandry and retain the peculiar quality of being good instructors. You gain something every time you read THE RELIABLE POULTRY JOURNAL.

The four papers above mentioned ought to be on every farm and ranch. Taken singly they cost $\$ 2.00$ a year. By our co-operative clubbing arrangement we are enabled to offer all four papers one year for One Dollar. Address us at once without fail.

THE hale PUblishing CO., 35no Vista Ave., St. Louis, Mo. 
LIBRARY OF CONGRESS

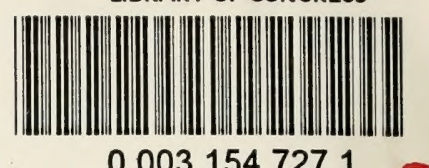

00031547271

\section{Hollinger Corp.}

pH 8.5 